Q L 639

. 66

coprá

FT MEADE GenColl 


$$
\text { 웅 }
$$





\section{OBSERVATIONS ON FISH SCALES}

By T. D. A. Cockerell

From BULLETIN OF THE BUREAU OF FISHERIES, Volume XXXII, I9I2 Document No. $779: \therefore::::: \because: \because: \quad: \quad$ Issued October 25, I913
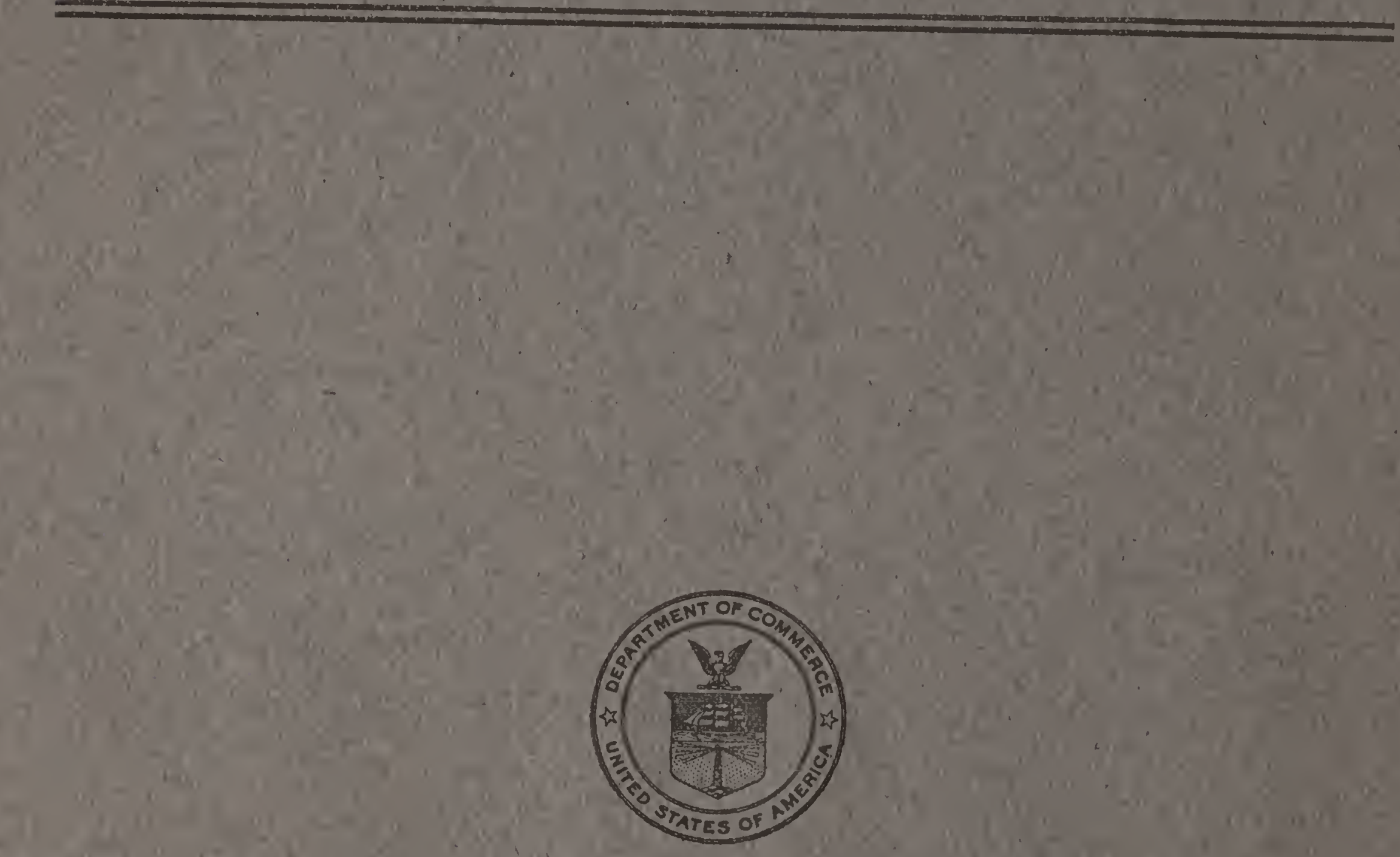

WASHINGTON : : : $: \quad: \quad:$ GOVERNMENT PRINTING OFFICE $: \quad: \quad: \quad: \quad: \quad: \quad: 1913$ 


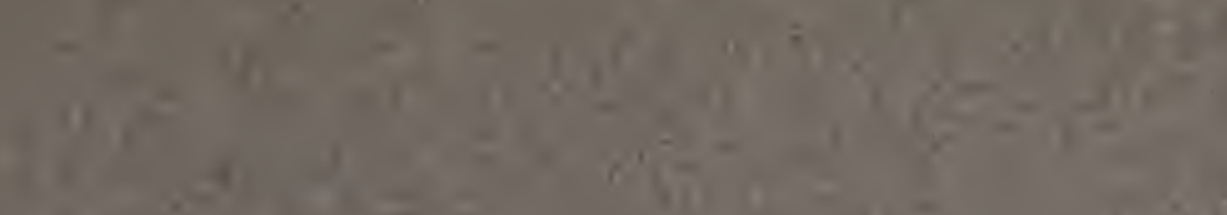
Wiftis on

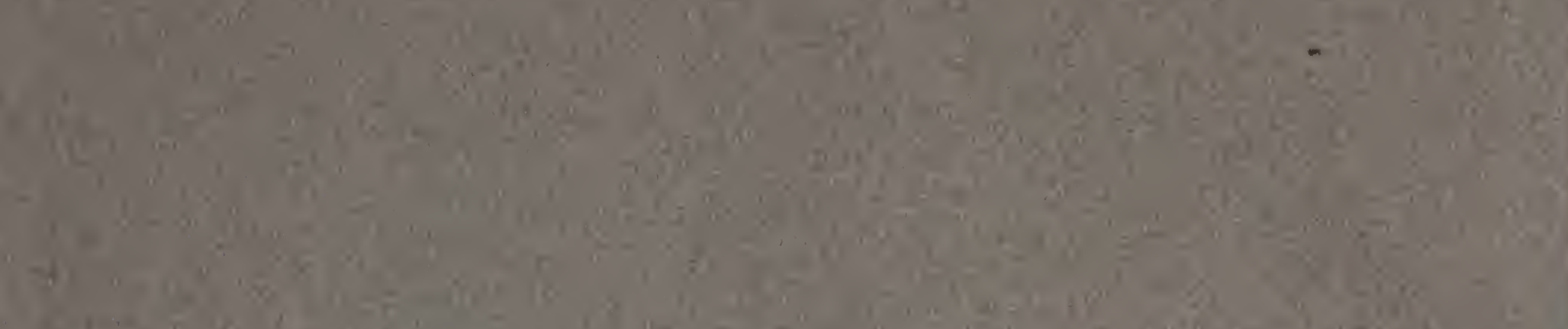
(60.

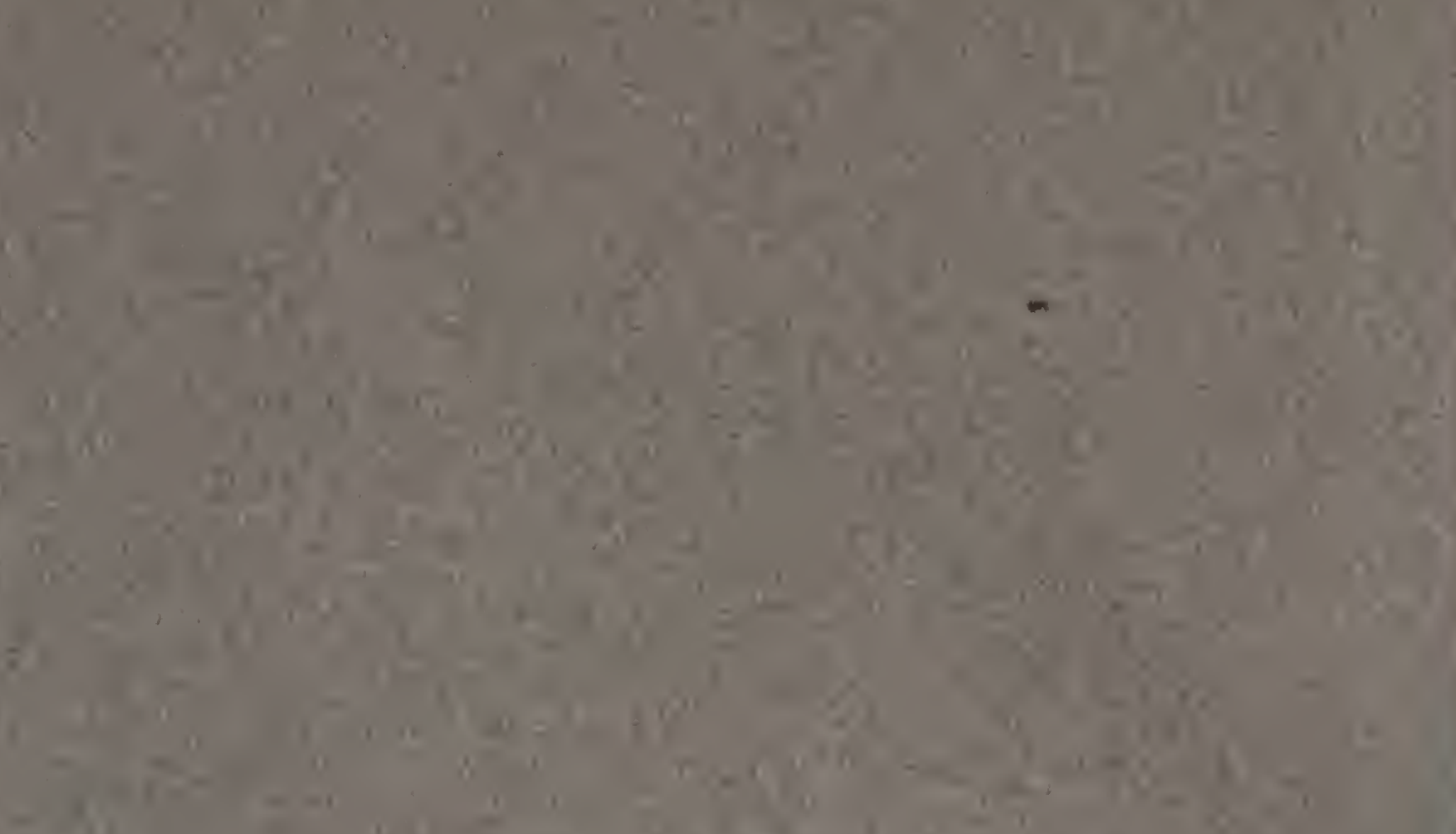
1.

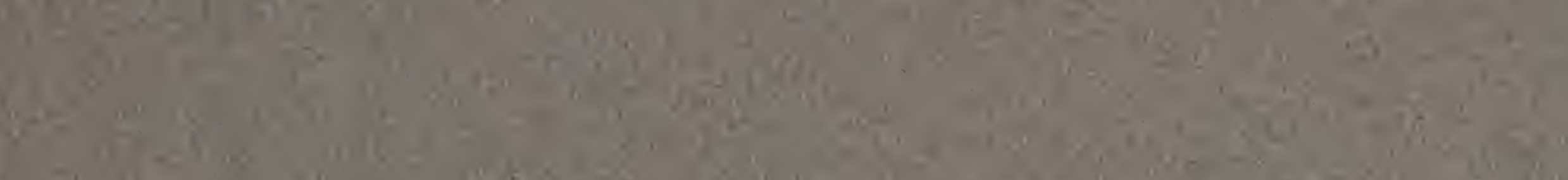

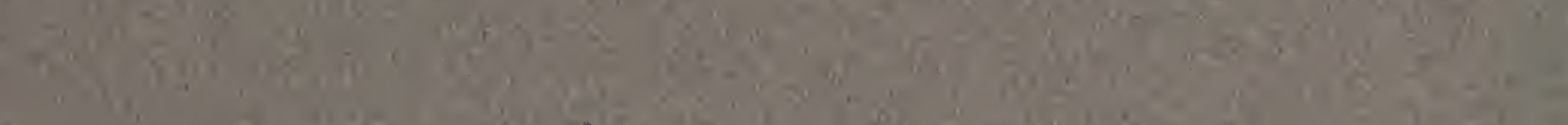

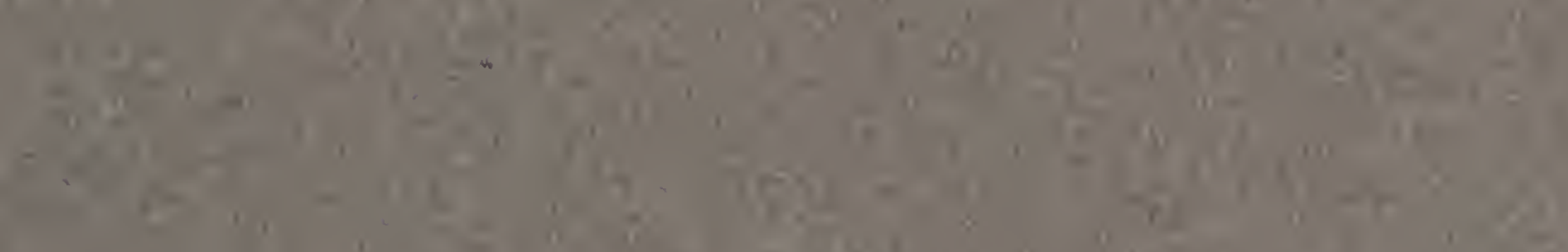

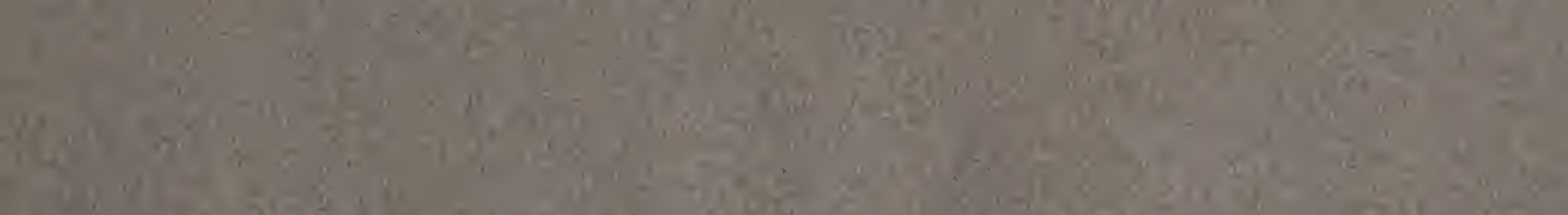

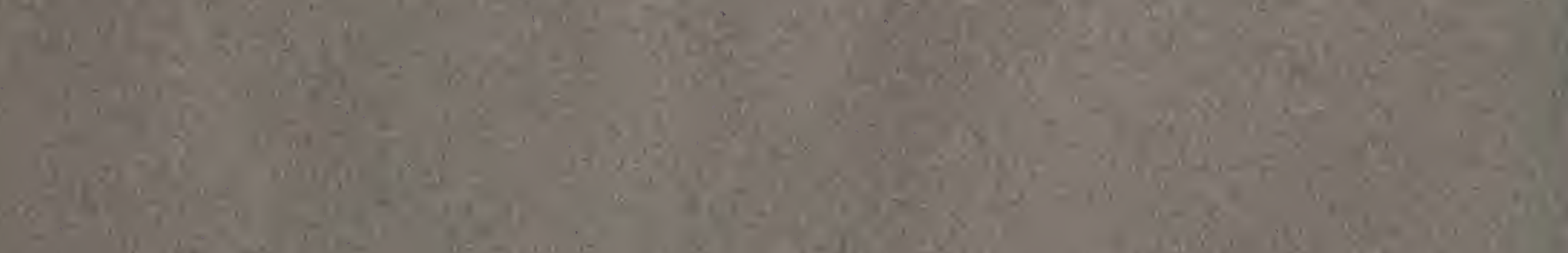
Q

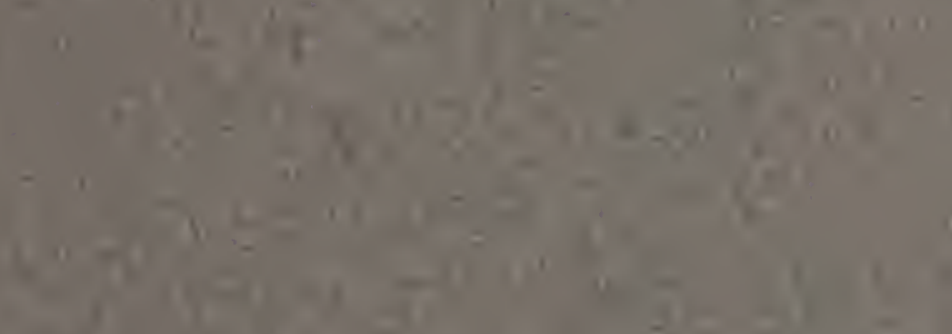

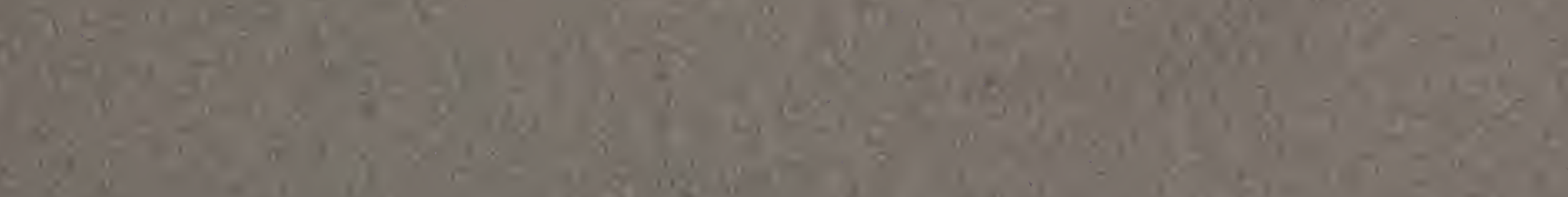






\section{OBSERVATIONS ON FISH SCALES}

By T. D. A. Cockerell

From BULLETIN OF THE BUREAU OF FISHERIES, Volume XXXII, I9I2

Document No. $779: \quad: \quad: \quad: \quad: \quad: \quad: \quad: \quad: \quad: \quad$ Issued October 25, 1913

$=$
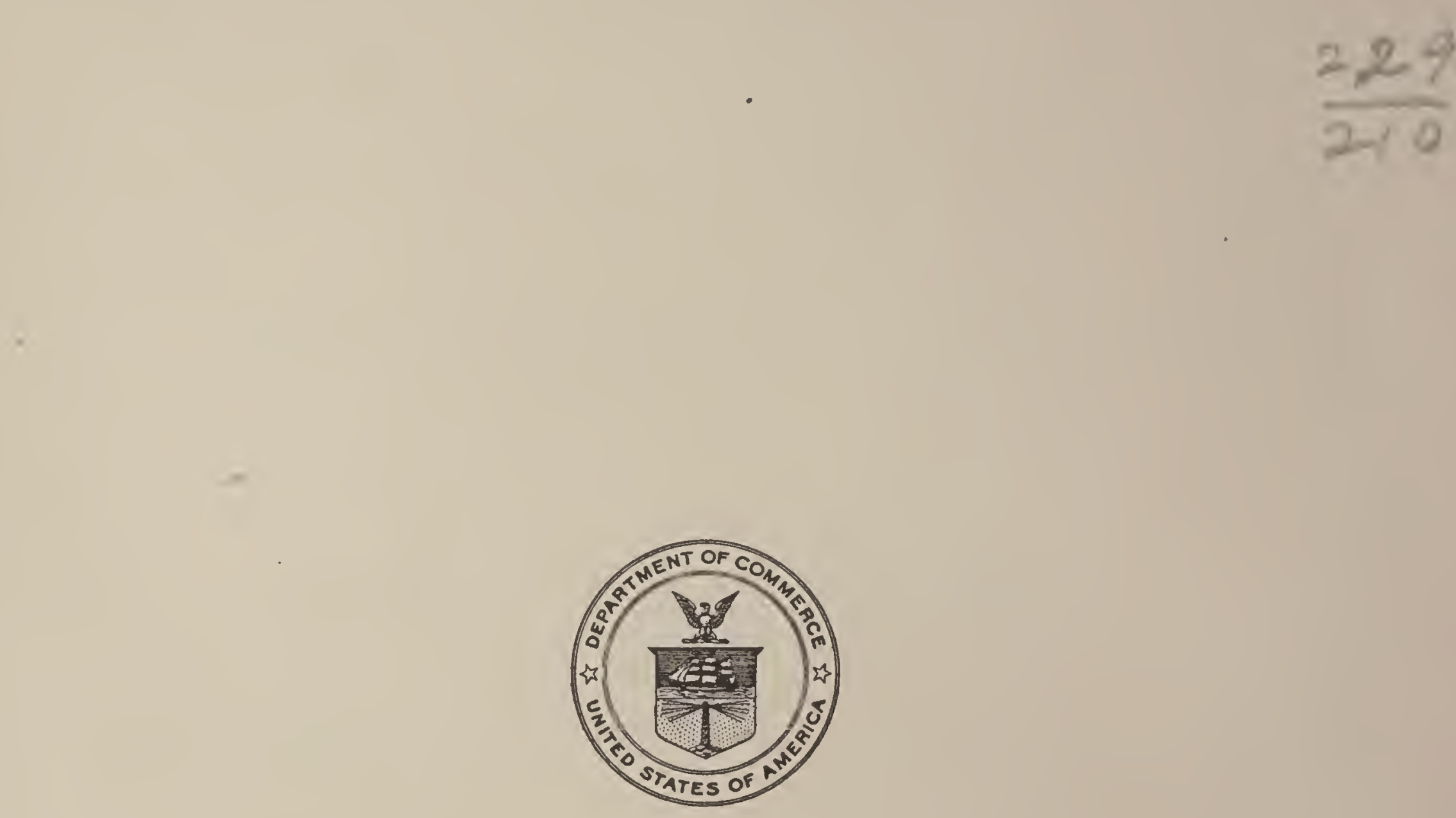

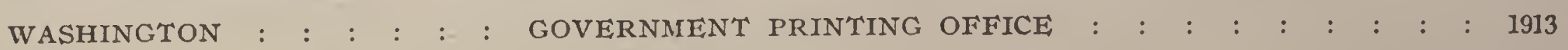




$$
Q^{v^{3}} C^{b} x^{x^{2}}
$$

D. OF $\mathrm{D}$. Nov 10 1919 


\section{OBSERVATIONS ON FISH SCALES}

By T. D. A. Cockerell

University of Colorado, Boulder, Colorado 



\title{
OBSERVATIONS ON FISH SCALES.
}

\author{
$*$ \\ By T. D. A. COCKERELL, \\ University of Colorado, Boulder, Colo. \\ INTRODUCTION,
}

In a paper on "The Scales of Freshwater Fishes" (Biological Bulletin of the Marine Biological Laboratory at Woods Hole, Mass., vol. xx, May, I9II) I have given an account of the recent work on teleostean fish scales and have discussed some of the problems presented by the scales of freshwater fishes. Until recently it has been impossible to do much with the scales of marine fishes, owing to the difficulty of obtaining adequate materials. For the same reason very little was done on the spiny-rayed freshwater groups, the Percidæ, Centrarchidæ, etc. During the summer of I III, however, I was enabled to continue the work in the laboratory of the Bureau of Fisheries at Woods Hole, where the director, Dr. F. B. Sumner, afforded me every possible facility and put at my disposal a large series of fishes representing many families. I have also been very greatly indebted to the Bureau of Fisheries, through Dr. Hugh M. Smith and Dr. B. W. Evermann, for numerous and important specimens from the collections at Washington. At the National Museum Mr. B. A. Bean and Mr. A. C. Weed gave me much help and supplied scales of some important genera, while other very valuable materials were secured from the Museum of Comparative Zoology, through the kindness of Dr. S. Garman. As in former years, I have been indebted to Dr. Boulenger for some of the rarest forms. With all this the outlook has been greatly enlarged; but of course the results here reported are quite insignificant compared with those which will doubtless be attained, mainly by other workers, in the future. The whole subject is still in a preliminary stage, and when it is considered that the ideal program is no less than the examination and description of the scales of every scaly fish, with figures of all the genera, it becomes evident that there is work ahead for an indefinite number of years.

A few years ago an eminent European ichthyologist expressed the opinion that the detailed work on scales was a waste of time; for, said he, "We have other excellent characters on which to classify fishes, so why bother with scales?" Possibly this particular authority will never be converted to lepidology, but I do not believe anyone could spend much time in the minute study of scales without becoming convinced of their great value for purposes of identification and classification. Like all other structures, they vary, and present characters of all degrees of significance and stability; in 
the earlier work we made some mistakes because of poor judgment in these matters. The correct estimation of the importance of particular scale characters can only come with experience, and if through lack of it some unsound opinions are expressed in this paper, the fact should not be used as an argument against the study of scales.

I have adopted, for the purposes of the present paper, the classification given by Dr. D. S. Jordan in his recent ( 1907 ) work "Fishes," pages 757-77I. It is only necessary to compare the classification in recent standard works by Jordan, Boulenger, and Goodrich, together with the essays of Regan, to perceive that there is still latitude for much difference of opinion in regard to fish taxonomy. Neither the authors cited nor anyone else would pretend to be able to present a classification which is nearly perfect, although many important matters are generally regarded as settled. In the slow approximation toward a system based on real relationship, lepidologists venture to think that they may have a part, and the present essay is written largely with this end in view.

The cost of the photographs used to illustrate this paper has been defrayed by a grant from the American Association for the Advancement of Science.

Two corrections which I have had to make in this paper since it was written may be worth citing, as illustrating certain dangers of error, and at the same time bringing out clearly the general reliability of scales for identification.

Under Boleosoma nigrum I had written that the scales from Osterville, Mass. (from the collection at Wood's Hole), were so unlike those from Indiana that I supposed them to be wrongly determined. Dr. Sumner has since very kindly looked up the specimens, and reports that they are really Boleichthys fusiformis. In the case of Carpiodes velifer, I used scales from the fishes forming the basis of Juday's record for Boulder County, Colorado, without making any study of the fishes themselves. I noted with surprise that they corresponded "very well with the scales of the common goldfish." Dr. Max Ellis, going over the collection, has discovered that the specimens are in fact wild, dark-colored examples of the goldfish, Carassius auratus.

\title{
Class TELEOSTOMI. The true fishes.
}

\section{Subclass CROSSOPTERYGII.}

\section{Order ACTINISTIA.}

\author{
CELACANTHIDAE (Fossil).
}

Dr. A. S. Woodward (Catalogue of Fossil Fishes, pt. 2, pl. xIv) has figured the scales of Colacanthus. The figures are excellent, but unfortunately show only the apical (exposed) portion, which is ornamented with broad grooves running obliquely toward the middle line. Through the kindness of Dr. L. Hussakof, I have obtained the loan of several scales of Colacanthus robustus Newberry, from the Carboniferous of Mazon Creek, Ill. These show that the scale is elongate in form, with a large basal region wholly free from grooves, and consisting entirely of very fine longitudinal fibrillæ, exactly as in Amia. The scales are about $12 \mathrm{~mm}$. long and 8 broad.

There is a striking resemblance between the apical (exposed) area of Colacanthus, with its grooved lines, and the same area in the South American characinid Lebiasina bimaculata Cuvier \& Valenciennes. 


\section{Order CLADISTIA.}

\section{POLYPTERIDE.}

The scales of Polypterus endlicheri Heckel from the White Nile (British Muscum) are entirely of a dense bony consistence, the exposed surfaces rhombic or diamond-shaped with an enamel-like coating. The scales are produced into a long concealed process, and each has a peg or tooth fitting into a hole or socket in the next scale. Although Polypterus belongs to a very primitive group, its scales must be considered highly modified; the protection they afford may perhaps explain the survival of the genus. It is in Colacanthus, not in Polypterus, that we get the real clue to the affinities of the crossopterygians.

\section{Subclass DIPNEUSTI. Lungfishes.}

\section{Order CTENODIPTERINI.}

\section{CTENODONTIDAE (Fossil). Comb-toothed Lung fishes.}

The large scales of Sagenodus from the Carboniferous of Mazon Creek, Ill. (American Museum of Natural History), almost entirely agree with those of the living Neoceratodus. Aside from the irregular radii, forming a network in the central part of the scale, both form and structure are very near to those of the bowfin, Amia; and both, except for the lack of grooves in the exposed region, approach Colacanthus. The one important feature in which all these agree is the large concealed area consisting of longitudinal fibrillæ. Among the Teleostei we find this retained only in the bonefishes, Albulidæ.

\section{Order SIRENOIDEI. Sirenoid fishes.}

\section{CERATODONTIDE. Flatheads.}

Neoceratodus forsteri, from Queensland (British Museum), has very large elongated scales with longitudinal beaded fibrillæ and a radial system of reticulation. (Science, May 26, rgII, p. 83I.) The radial network and the tuberculate or beaded fibrillæ distinguish these scales from those of $A$ mia.

LEPIDOSIRENIDE. Scaly sirenids.

The scales of Lepidosiren and Protopterus are briefly described in Science, May 26, rgrr, page 83 I. Although these fishes come from widely separated regions (South America and Africa) and undoubtedly represent different subfamilies (Lepidosireninæ and Protopterinæ), their scales are almost exactly alike. There is a strongly developed radial network, as in the Osteoglossidæ, and the surface is minutely tuberculate, the tubercles derived from beaded fibrillæ. The scales are inclosed in the skin, and are circular or approximately so, not elongate as in Neoceratodus and Sagenodus.

\section{Subclass ACTINOPTERI.}

\section{Superorder GANOIDEI.}

In this case I prefer to write "superorder," rather than "series," as the term defines the rank of the category in relation to others.

\section{Order GINGLYMODI.}

\section{LEPISOSTEIDA. Gar pikes.}

The rhomboidal ganoid scales of the gar pikes Lepisosteus have a very close superficial resemblance to those of Polyptcrus, a case doubtless of convergence of type, due largely to the mechanical necessities of the situation. The scale of Lepisosteus is not so highly specialized as that of Polypterus, since it lacks the well-defined peg-and-socket arrangement. (For a further discussion of the scales of these genera, see Goodrich, Proceedings Zoological Society of London, November, r907, p. 762-763.) 


\section{Order HALECOMORPHI.}

\section{AMIIDE. Bowfins.}

I still write Amia and Amiidæ for the bowfin, being unconvinced that the rules of nomenclature require the change which has been proposed. The scale of Amia has been discussed in several of my earlier papers (e. g., Smithsonian Miscellaneous Collections, vol. 56, no. I, p. r). It has simple longitudinal fibrillæ, and no radial network. In its general structure it is not far from Colacanthus, or indeed very remote from Neoceratodus and Sagenodus. No comparison is possible between the scales of Amia and Lepisosteus, and it is Amia alone which points toward the Teleostei.

Superorder TELEOSTEI. The bony fishes.

Order ISOPONDYLI. The isospondylous fishes.

I would change Jordan's arrangement of families to the extent of placing the Albulidæ first among the living groups, as undoubtedly the most primitive. It alone has the strictly longitudinal basal

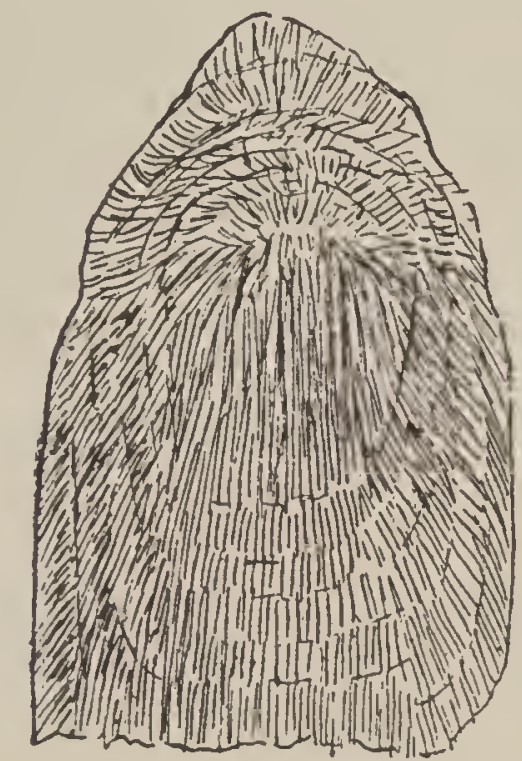

FIG. 1. - A mia calva.

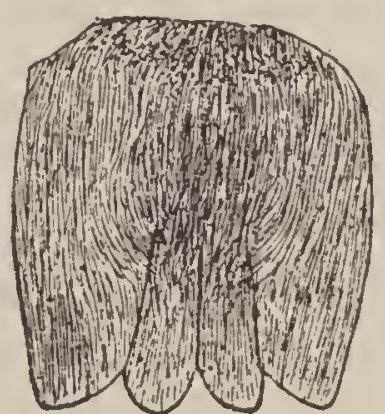

Fig. 2.-Albula vulpes (Albulidæ). Bureau of Fisheries.

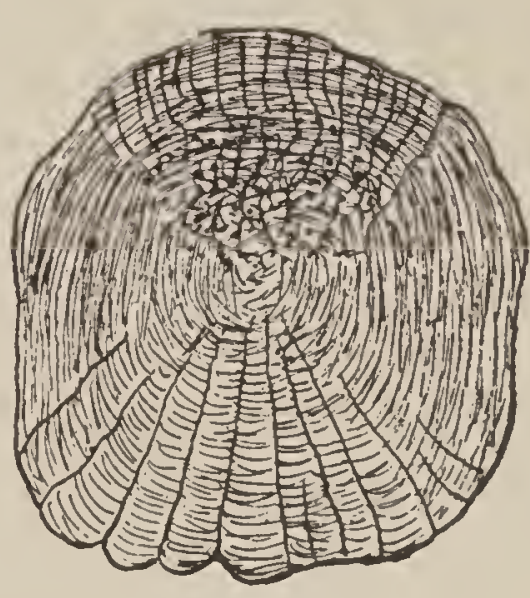

Fig. 3.-Elops saurus (Elopidæ). Bureau of Fisheries.

fibrillæ, which are tuberculate as in the Dipneusti. It alone, also, has two transverse series of valves to the bulbus arteriosus instead of one, another primitive character.

\section{ALBULIDE. Bonefishes.}

The scale of Albula is shown in text figure 2; that of Dixonina does not differ. In outline and general form these scales resemble those of Synodus and Lucius or Esox (pl. xxxv, fig. 19, 20), but these latter have transverse basal circuli.

\section{ELOPIDE. Ten-pounders.}

For a discussion of the scales of Elops see Smithsonian Miscellaneous Collections, volume 56, no. 3, page 3. Their structure shows nothing especially primitive; the basal circuli are very finely beaded, the lateral ones simple. The apical circuli, above the nucleus, break up into transverse labyrinthiform markings, the sculpture much coarser than that of the normal circuli.

\section{MEGALOPIDE. Tarpons.}

Jordan makes a separate family for the tarpons, although on an earlier page of the same book he follows the more usual custom of referring them to the Elopidæ. I am indebted to Mr. V. N. Edwards for a scale of Tarpon atlanticus (Cuvier \& Valenciennes), from Woods Hole, Mass. It is of course very large ( $62 \mathrm{~mm}$. long, and almost as broad), and is formed much as in Elops, differing, however, by having only three basal radii ( 2 to 20 in Elops), the basal margin broadly scalloped much as in Synodus. The 
scale is indeed curiously similar in form and structure to that of Synodus, though the nucleus is not so far apicad. The region above the nucleus is minutely roughened or tuberculate, and the apical circuli are longitudinal. The basal circuli are finely beaded.

\section{HIODONTIDE. Toothed herrings.}

The scales of the moon-eye Hiodon tergisus are discussed in Smithsonian Miscellaneous Collections, volume 56, no. 3 , page 3 . They have much in common with Elops, but the wholly transverse fine circuli of the apical field are not at all modified above the nucleus. The basal radii are numerous and irregular, inclined to be divided into two groups, and the basal margin is undulate, not scalloped. The basal circuli are without distinct beading. The scale is of a cyprinoid type.

\section{CHIROCENTRIDE. Long herrings.}

The long herring, or dorab, Chirocentrus dorab (Forskål), from the Philippine Islands, has transverse circuli and radii, essentially as in Clupeidæ, the radii usually angled in the middle. There are also irregular basal longitudinal radii, few in number, much as in the anchovy Stolephorus argyrophanus. On page II 3 of volume XXIII of the Proceedings of the Biological Society, Washington, for "five transverse circuli" read "fine transverse circuli," and it is the basal, not the apical field, which has these more widely spaced circuli. Upon minute comparison I find that the whole arrangement, both circuli and radii, agrees essentially with Stolephorus argyrophanus, and hence in its scales Chirocentrus is to be compared with the Engraulidæ rather than with the Clupeidæ. The scale is, in fact, wholly as in the engraulids.

\section{ENGRAULIDIDE. Anchovies.}

I alter Jordan's arrangement by placing these before the Clupeidæ, as being more primitive, at least as to the scales, and also nearer the chirocentrids. Dr. Max Ellis has prepared a paper fully discussing the available material. Some of the species show an evident reticular network, in one case so well developed that the scale looks like that of some osteoglossid.

\section{CLUPEID E. Herrings.}

I here consider only the Clupeinæ, of which I have examined nearly all the American genera. Two tribes are indicated, Brevoortiini, for Brevoortia, and Clupeini, for the other genera. In the menhaden, Brevoortia tyrannus (Latrobe), the apical margin of the scale is produced into long parallel teeth with very slender ends. These teeth arise from a pellucid apical zone, and the intervals between them are prolonged basad as grooves for a distance about equal to the length of the teeth. Below these grooves are numerous small and short grooves looking like roots, the large grooves seeming to be the stems from which they arise. Below this the scale is entirely covered with very fine transverse circuli, and has in addition irregular pits and two transverse radii. The dentate scale margin is by no means peculiar to Brevoortia; it is quite distinct, for example in Alosa and Clupea, but the teeth are very irregular and by no means so long or tapering. In juvenile Alosa the margin is not dentate. The pitting seen in Brevoortia is also very strongly developed in some scales of the thread herring, Opisthonema oglinum (Le Sueur), from Woods Hole; it is evidently derived from evanescent transverse radii. In some scales of $O$. oglinum there are five transverse radii, all but the uppermost broken in the middle; there is then no pitting, but the well-pitted scales have only the upper radius. In the pilchard, Clupanodon pilchardus, from Palermo, Italy (Bureau of Fisheries), there are seven or eight transverse radii, all widely broken in the middle except the first, the lower ones oblique, the whole reminding one of the ribs of the human skeleton seen from in front. The extremely fine circuli are strictly transverse, meeting the lateral margins at right angles. I find essentially the same in the West Indian sardine, Clupanodon pseudohispanicus Poey, from Woods Hole ( $\mathrm{pl}$. xxxv, fig. I8), but in two scales I notice that the circuli curve upward on one side only.

Comparing Clupanodon with the sea herring, Clupea harengus (from Woods Hole and Sandy Island), two differences are at once apparent. In Clupea the transverse radii are commonly (though not uniformly) entire, or not interrupted in the middle, whereas in Clupanodon they are (except the first) 
quite regularly interrupted; in Clupea also it is common to find a pair of irregular apical radii, joining basally to form a sort of $U$. In Clupea the lateral circuli, following the trend of the transverse radii, reach the margin obliquely, not at right angles as in Clupanodon; this seems to be in some degree a matter of age, yet the large scales from Woods Hole, in which the obliquity of the circuli is very strongly marked, show growth lines delimiting various younger stages, and when less than half grown the circuli were already moderately oblique. It is a curious thing that the scales from Sandy Island (Bureau of Fisheries) have the transverse radii more numerous, much less regular, and interrupted at intervals, the circuli more transverse, in the young very little oblique, and the lower limit of the hyaline apical area straight or almost, whereas in the Woods Hole scales it is concave or even broad V-shaped. Are there two types of herrings, or is this individual variation?

The large scale of the shad, Alosa sapidissima, has been figured in Smithsonian Miscellaneous Collections, volume LVI, no. I, page 2 , and discussed at length in the Proceedings of the Biological Society of Washington, volume XXIIr, pages $6 I_{-62}$. It is shown that the transverse radii are derived from the apical radial system, all stages of transition being visible. The adult Alosa scale has the circuli and radii at the sides very oblique; in some scales the radial system is very highly developed, with very numerous apical radii, and those about the middle of the scale variously anastomosing, forming an irregular network. There is, however, no approach to the type of network seen in some Engraulididæ and better developed in Osteoglossidæ. So far as the scale goes, Alosa must stand at the base of

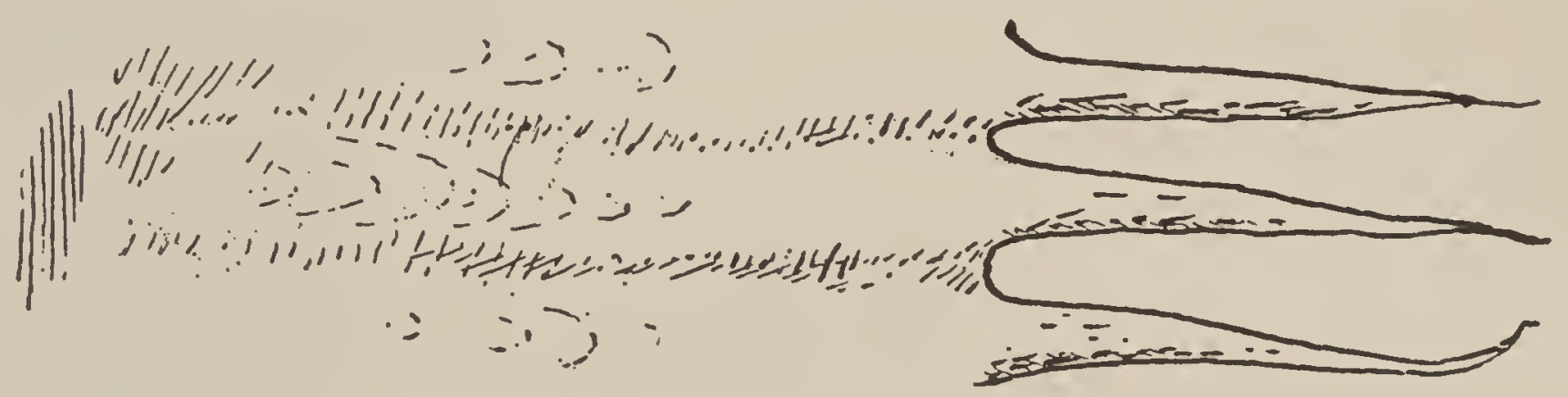

FIG. 4.-Brevoortia tyrannus (Clupeidæ). Apical teeth. Bureau of Fisheries.

the clupeine series, with Clupea close to it but a little more advanced. Clupanodon then represents a considerable further step in the direction of clupeine specialization, with the fixation of the more characteristic features.

In Sardinella humeralis (Cuvier \& Valenciennes), from Tampa, Fla., the scales differ conspicuously from Clupea, Clupanodon, Alosa, etc., in being much broader than long, the lower corners obtusely almost rectangular. The circuli are strictly transverse, not oblique; there are two widely separated entire transverse radii, and part of a third one forming a small reversed broad $V$ on the lower margin; the lower margin of the hyaline area is slightly concave. These scales are perhaps not adult; they resemble in many ways the immature scales of $A$ losa.

The scales of the alewives, Pomolobus, have the lateral circuli moderately oblique, except in the young; the undulating transverse radii distinctly rather widely spaced, often broken in the middle but not regularly or widely so, as in Clupanodon. Two species before me are rather easily distinguished:

Pomolobus cestivalis (Mitchill). Glut herring. Scales about as long as broad; lower margin of hyaline area concave.

Pomolobus pseudoharengus (Wilson). Branch herring. Scales conspicuously broader than long; lower margin of hyaline area straight. In a former paper I said I did not know how to distinguish young scales of $P$. pseudoharengus from young of Alosa sapidissima. However, in the Alosa the lower margin of the hyaline area is uniformly distinctly concave; in $P$. pseudoharengus it is straight or even convex, except in the very earliest stage, when the diameter is much less than a millimeter. Reviewing the Clupeinæ, it appears that we may place Alosa at the base of the series, and just above it Clupea. Then Clupanodon stands at the end of a branch, from the side of which springs Opisthonema, leading directly toward Brevoortia. From an earlier part of the same branch may arise Pomolobus, and somewhere near here Sardinella. All this is based on the scales, and must of course be modified when the structures are considered. 
The character given in Jordan and Evermann's key for all the clupeines except Brevoortia, "scales with their posterior [apical] margins entire and rounded" is not accurate, although Brevoortia scales are readily separated from the others by their long weak teeth.

\section{PHRACTOLEMIDA.}

Phractolcmus is a living African fresh-water genus; Jordan has the family printed by error in italics, as extinct. The scales of the only known species are described in the Proceedings of the Biological Society of Washington, volume XxIII, page II2, and figured in Biological Bulletin, volume Xx, plate III, figure I 7a. They strongly suggest certain of the Characinidæ.

\section{OSTEOGLOSSIDE. Bony-tongued fishes.}

There are at least two subfamilies, Osteoglossinæ (Osteoglossum and Scleropages) and Heterotinæ (Heterotis). The scales of this group, remarkable for their regular network and beaded circuli (primitive characters recalling the Dipneusti), have been discussed in the Proceedings of the Biological Society of Washington, volume XxIIr, page III, and volume XxIV, page 39; Science, May 26, I9II, page 83I; and Heterotis is figured in Biological Bulletin, volume $\mathrm{xx}$, plate Irr, figure 20. Mr. W. M. Mann has kindly sent me scales of the Amazon bone-tongue, Arapaima gigas (Cuvier), which Eigenmann makes the type of a distinct family, Arapaimida. They are about $78 \mathrm{~mm}$. long and 55 broad, superficially like those of Neoceratodus. The exposed part has a very coarse labyrinthoid rugosity. The concealed part has elongated reticulations and beaded circuli; the reticulation very irregular and not nearly so well developed as in Osteoglossum. The scale is really very near to that of the Nile bone-tongue, Heterotis.

\section{PANTODONTIDA. Pantodonts.}

Living African fishes, only one species known. The scales are described in the Proceedings of the Biological Society of Washington, volume Xxmr, page II2, and figured in Biological Bulletin, volume $\mathrm{xx}$, plate III, figure $\mathrm{I} 8$. The circuli are strongly beaded.

\section{NOTOPTERIDE. Finbacks.}

Fresh-water fishes of the Ethiopian and oriental regions, considered by Boulenger to be nearest to the Hiodontidæ. The scales of the African Notopterus afer Günther are described in the Proceedings of the Biological Society of Washington, volume XxII, page II2. In this place $I$ have remarked on the resemblance of the scales to those of Gadus. This is certainly true as regards shape and general appearance, but on close comparison it is seen to be wholly superficial. In the gadines the numerous fine radii extend in all directions from the nucleus; in Notopterus, except for a series of striæ just below the apical margin, they are wholly basal, and only the central ones reach the nuclear region. In Notopterus these radii are only about half as dense (close) as in Gadus, but on the other hand the circuli are much denser. The circuli of Notopterus are not at all beaded.

\section{SALMONIDAE. Salmon, trout, etc.}

Very good figures of Salmo scales have been published by Mr. J. Arthur Hutton in his pamphlet on "Salmon Scale Examination and its Practical Utility" (London, IgIo). He shows that the life of the fish affects the growth of the scales, so that by examining the scales it is possible to determine the approximate age, the time spent in the river and in the sea, and other important facts. The salmonoid scales before me are the Atlantic Salmon, Salmo salar Linnæus, Woods Hole, Mass.; the golden trout, S. roosevelti Evermann, cotype, Mount Whitney, Cal.; Coulter's whitefish, Coregonus coulterii Eigenmann \& Eigenmann, cotype, Kicking Horse River, Field, British Columbia; the brook trout, Salvelinus fontinalis (Mitchill), Woods Hole, Mass.; the blueback or red salmon, Oncorhynchus nerka (Walbaum), Wallowa Lake, Oreg. (J. J. Stanley). I have figured the scale of the blackfin, Leucichthys nigripinnis (Argyrosomus nigripinnis Gill), in Biological Bulletin, volume xx, (I9I ), plate I, figure 2. The scales of Salmo are more or less oval, with well developed concentric circuli, which variously fail in the apical region; the radii are absent. Scales of Salvelinus and Oncorhynchus are essentially the same; with 
the material before me I am not able to make any satisfactory table for their separation. Leucichthys nigripinnis is distinct by the evident laterobasal angles. Coregonus coulteri scales are about $\mathrm{I} .5 \mathrm{~mm}$. long by 2 broad, varying to approximately circular, but apparently never (at least on the middle of the side of the fish) longer than broad, as is usual in the Salmo group. The circuli are very widely spaced, and there are rather obscure indications of laterobasal angles. These Coregonus scales are perhaps immature. It is probable that the following characters are valid for the subfamilies:

COREgONINA, WHITEFISHES AND LAKE HERRING.-Scales as broad or broader than long, with laterobasal angles more or less developed.

SALMONINAE, SALMON, TROUT, ETC.-Scales nearly always longer than broad, without laterobasal angles. Of these, the Coregoninæ must apparently be considered the more primitive.

\section{ARGENTINIDA. Smelts.}

Osmerus mordax Mitchill, from Menemsha Bight, Mass. (J. T. Field), has approximately circular scales about $2.5 \mathrm{~mm}$. diameter, without radii. The circuli are very widely spaced except basally, where they are crowded; they are obtusely angled in the middle line above and on each side. The laterobasal corners are very obtuse but evident; the basal middle is broadly produced into a rounded lobe, which is usually emarginate. The nucleus is far toward the base of the scale, approximately on a level with the laterobasal corners.

This scale is in general related to that of the Coregoninæ, but is readily distinguished by the position of the nucleus.

\section{SYNODONTIDE. Lizard-fishes.}

Rather large semicircular cycloid scales; nucleus a little (Trachinocephalus) or considerably (Synodus) above the middle; very strong basal plicæ (2 or 3 in Trachinocephalus, 3 or 4 in Synodus); circuli normal, quite dense in Synodus, rather widely spaced in Trachinocephalus, the apical ones longitudinal; laterobasal angles evident but obtuse; apical marginal area broadly thin and sculptureless, in the manner of certain clupeids, but the submarginal area, or marginal area of the scale proper, sculptureless, except for scattered punctiform markings, its margin irregularly minutely dentate (more evidently in the Synodus), as if very irregularly broken. Scales of Synodus yellowish, of Trachinocephalus colorless.

The species studied are Trachinocephalus myops (Forster), the ground spearing, from Woods Hole, Mass., and Synodus fotens Linnæus, the lizard fish (pl. xxxv, fig. I9), from Galveston, Tex. (Evermann). The apical structure seems to be prophetic of the acanthopterygian type of ctenoid scale; in the Gerridæ (Xystcma cinereum Walbaum) the apical margin is very thin, covered with minute shadowy diamondshaped markings, the vestiges of the disappearing teeth; no such vestiges can be seen in the Synodontidæ, although the superficial appearance is similar. Jordan notes of Synodontidæ that the head is scaly, "a character rare among the soft rayed fishes," but usual among Acanthopterygians.

\section{MAUROLICIDAE.}

Maurolicus pennanti (Walbaum), from Woods Hole, Mass., has easily deciduous, extremely thin scales, with widely spaced evanescent circuli. According to Jordan, the Maurolicidæ are scaleless, but no doubt the specimens examined had lost their scales. Dr. F. B. Sumner tells me that he carefully worked over the Woods Hole species and noted the presence of scales.

In the related family of Myctophidæ, the lantern fishes, the scales of Myctophum resplendens, as figured by Günther, are better developed; broad, cycloid, regularly circulate, nucleus nearly central, about six strong basal folds. They are rather like those of Cypsilurus.

\section{Order APODES. Apodal fishes.}

Suborder ENCHELYCEPHALI. The eels.

\section{ANGUILLIDA. Fresh-water eels.}

The scale of the common eel (Anguilla rostrata or chrisypa) is a remarkable structure, very unlike any of the scales discussed above. It is $2 \mathrm{~mm}$. long, or slightly over, narrow, and with rounded ends, approximately sausage-shaped in outline. The nucleus is central, and on an extremely fine reticulated 
framework are arranged concentric rings of oval elements, which are hyaline with narrow dense margins These oval bodies are actually capable of being detached, or more strictly speaking their surface layers are detachable, retaining their original form and appearance.
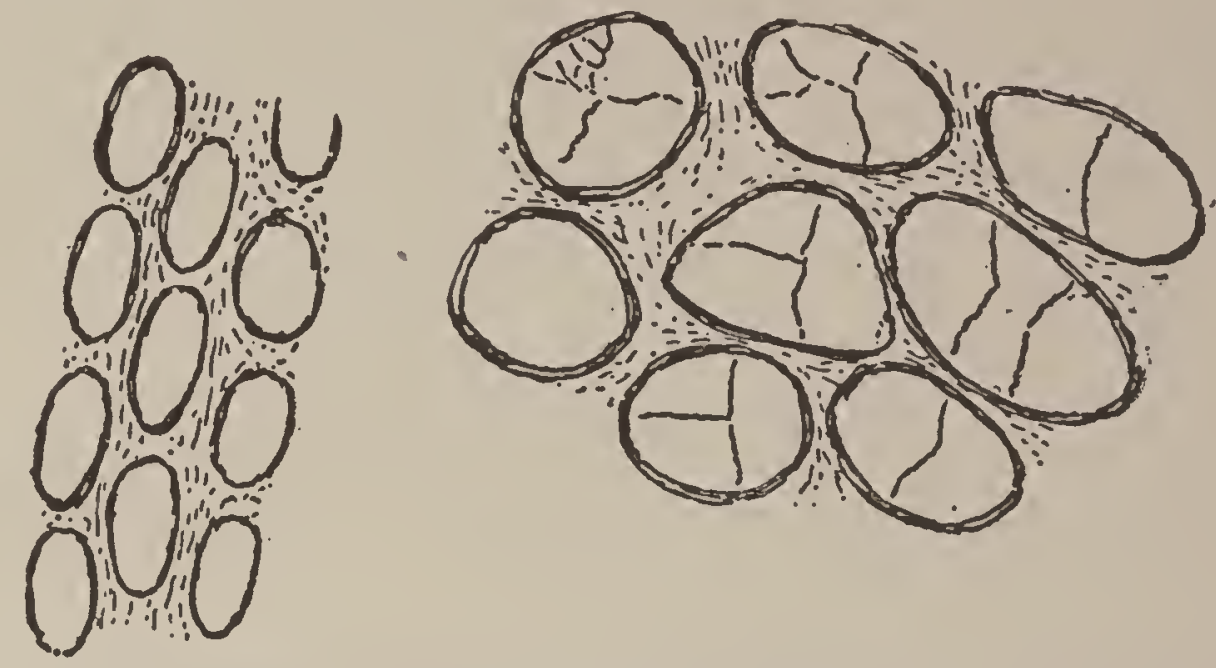

FIG. 5. - Anguilla rostrata (Anguillidæ). Details of sculpture. Bureau of Fisheries.
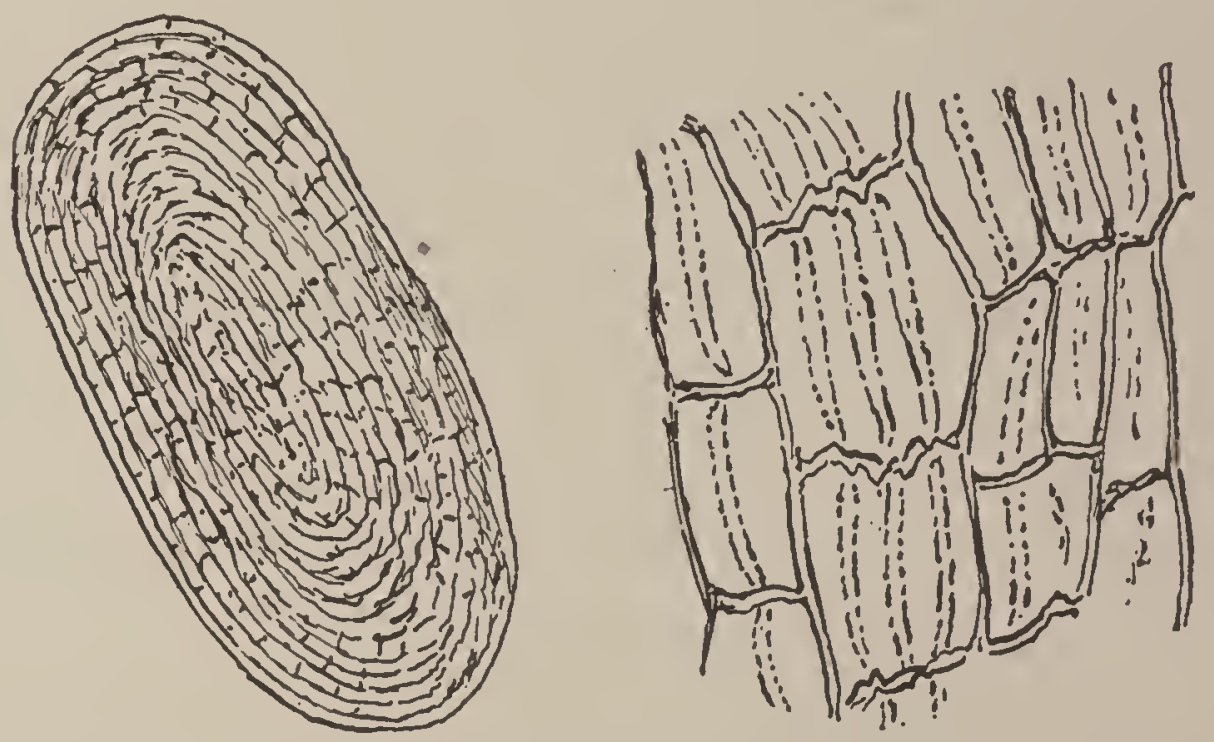

Fig. 6.-Synaphobranchus pinnatus (Synaphobranchidx). Bureau of Fisheries.
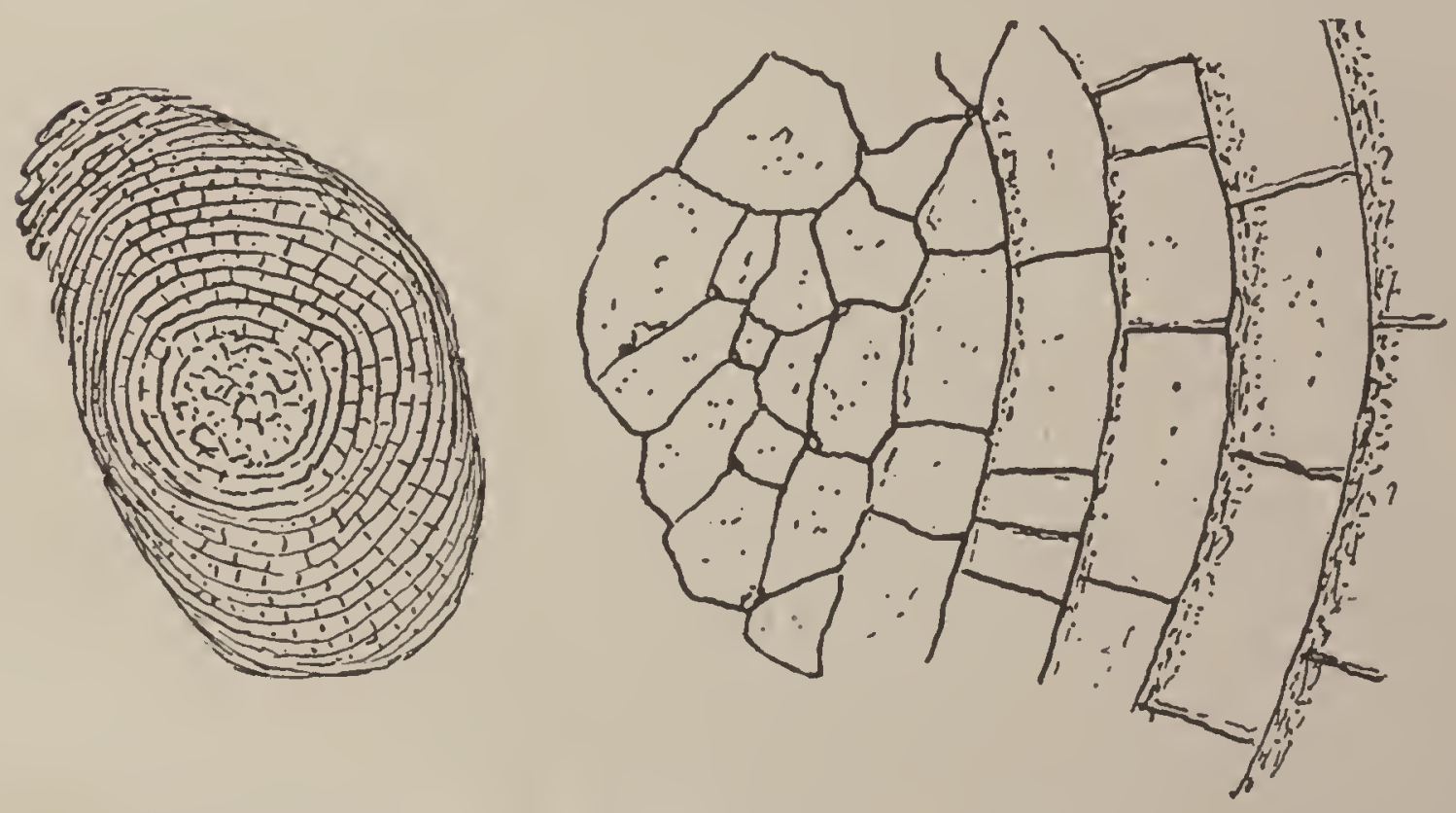

FIG. 7.-Ichthyophis glutinosus (Cæciliidæ). Amphibian scale. British MIuseum.

\section{SYNAPHOBRANCHIDE.}

In Synaphobranchus pinnatus (Gronovius), a deep-sea eel, the scales are shaped much as an Anguilla, but not so elongate, and very much smaller, the length about two-thirds of a millimeter. The general appearance and detailed structure are shown in the figure. In this scale we get a clue to the evolution 
of the Anguilla type, the structure, with its upper and lower layers, being much the same; but the upper layer exhibits more or less quadrangular spaces, due to the crossing of the radial and circular systems. The specialization of detachable oval plates does not exist, but it is possible to see how it might arise from a type resembling Synaphobranchus.

Although I have found nothing among the primitive fishes which seemed to lead toward the eels, there is a distinct resemblance, I believe not altogether superficial, to be observed in the scales of the cæciliid amphibians. I am greatly indebted to Dr. Boulenger for material of Ichthyophis glutinosus (see text fig. 7). Here the elongate quadrangular spaces are arranged like bricks in a wall, but in concentric circles, while the center of the scale is reticulate and minutely tuberculate, quite closely simulating the condition in the Lepidosirenidæ. Thus in a remote and general way, Ichthyophis scales connect those of the eels with those of primitive fishes, suggesting that the eel type is really a very ancient one, not derived from any of the groups of fishes nearly associated with it in the classification.

In this connection the extinct Archencheli, considered primitive eels with isospondylous traits, become very important. I have never seen Urenchelys, but Dr. A. S. Woodward says of it, "scales rudimentary"; and under $U$. avus A. S. Woodward, he says of one specimen, "there are no traces of scales," but of another, "the brownish impression of the soft parts of the fish is curiously mottled, as if there were indications of small, rudimentary quadrangular scales." Looking in the opposite direction, we find an unexpected revival of the ichthyophoid type of scale, at least as regards the quadrangular areas, in the gadid Brosmius brosme, the cusk. The fine radii are broken so that, as in Ichthyophis, the bricklike spaces are largely laid in alternate fashion, not one directly above the other. In the pollocks, Pollachius and other genera, however, the radii are essentially continuous, and one can hardly doubt that the Brosmius scale was derived from a Pollachius-like type. In this connection it is worth while to note that Sphyrcena picuda has a scale pattern practically identical with that of Pollachius.

All things considered, it must be admitted that the eel type of scale could have been derived from something of the Sphyræna or gadid pattern, and hence it is not necessarily primitive. The resemblances noted are, however, interesting, and may not be without some significance.

According to Boulenger, the scales of the Murænolepididæ resemble those of the Anguillidæ.

\section{Order OSTARIOPHYSI.}

\section{Suborder HETEROGNATHI.}

\section{CHARACIDA (CHARACINIDE). Characins.}

The scales of the African species have been discussed in Smithsonian Miscellaneous Collections, volume 56, no. I. Those of the South American genera form the subject of a lengthy paper to be published by the Camegie Museum. This also includes the Erythrinidæ.

\section{Suborder EvenTognathI.}

\section{CYPRINIDA. Minnows and carps.}

The scales of this family have been discussed in numerous papers. I give here a list of the genera which I have examined, with references to literature and some additional information and figures.

\section{(A) AMERICAN GENERA.}

It is doubtful whether any genera of Cyprinidæ are common to America and the Old World, except, of course, those introduced by man.

Abramis auctt. Amer., the shiner=Notemigonus.

Acrocheilus Agassiz, the chisel-mouth. Proc. Biol. Soc. Wash., xxir, p. 2 ro (subfamily Chondrostominæ). 
Agosia Girard, the western dace. Proc. Biol. Soc. Wash., xxII, p. I57. Girard, Ichthyology of the Mexican Boundary Survey, p1. xxvir, fig. 6-8 (notabilis=oscula); p1. xxvi, fig. I0-12 (oscula); p1. Xxvin, fig. 6-8 (chrysogaster); p1. xxvin, fig. 2-4 (metallica-chrysogaster). Girard's figures show that the scales of the subgenera Apocope and Agosia are essentially of the same type, more or less elongate, with basal as well as apical radii. According to the figures, the scales of $A$. chrysogaster are distinctly different from those of $A$. metallica, the former rounded, the latter quadrate. Is it not probable that there are two species or races?

Algansea Girard. (P1. xxxII, fig. 3.) Proc. Biol. Soc. Wash., xxIv, p. 2 I3 $_{3}$ (A. sallai); Zoologischer Anzeiger, xxxvi, p. 476 (tincella); Biological Bulletin, xx, p. 373 (tincella, affinis, stigmatura). Girard figures the scales in Ichthyology of the Mexican Boundary Survey, pl. xxvII, fig. 2-4. They are of the same general type as those of Agosia, longer than broad, with basal as well as apical radii. According to the scales, Algansea does not seem near to Hybognathus (the scales of which are large and broad, without basal radii), but should be an herbivorous representative of the Agosia-Rhinichthys group, or related in some way to Temeculina. Among the herbivorous groups, it is by its scales nearer to the Chondrostominæ and Chrosominæ than to the Pimephalinæ. May we not regard it as a modified chondrostomine, pointing somewhat in the direction of the Agosia group? In any case the scale characters must be considered relatively primitive and indicative of affinity with Old World types.

Campostoma Agassiz, the stone-roller. Proc. Biol. Soc. Wash., Xxir, p. I22. Girard, Ichth. Mex. Boundary Survey, p1. xxv, figures scales of C. ornatum, anomalum (as nasutum) and formosulum; they are all broad, with nucleus far basad of the middle, and apical radii only; the general type of Notropis and many other American genera. This genus is the type of a distinct subfamily, peculiar to America.

Chrosomus Rafinesque, red-bellied dace. Biol. Bulletin, xx, p. 370, pl. I, fig. 5; Proc. Biol. Soc. Wash., XxII, p. I2I. Scale broader than long, with radii all around; the type that of the European Phoxinus. An isolated genus in America.

Cliola Girard. Proc. Biol. Soc. Wash., xxir, p. I89 (C. smithii). Girard, Ichth. Mex. Boundary Survey, p1. $x x x y$, fig. 22-24 (velox=vigilax). The scales are broad, with about I9 apical radii in C. smithii, about 8 or 9 (according to Girard's figures) in vigilax. The genus seems to stand between Pimephales and Notropis.

Cochlognathus Baird \& Girard. Girard, Icth. Mex. Boundary Survey, p1. Xxxv, fig. I5-I7, shows very broad scales with subbasal nucleus, the radii only apical, about ro or 12, not nearly reaching the nucleus. According to the figures the basal margin is strongly convex, not straight as shown in Cliola vigilax. Thus the base of the scale is practically as in Lavinia, while that of C. vigilax may be compared with Ericymba or Phenacobius.

Couesius Jordan, the chub-minnow. Proc. Biol. Soc. Wash., xxiI, p. I59. Near to Semotilus; apical circuli angulate in the middle.

Ericymba Cope. Proc. Biol. Soc. Wash., xxII, p. I62, pl. III, fig. I; Biological Bulletin, xx, p. 374, p1. v, fig. 28 (normal scale) and fig. 29 (latinucleate scale).

Exoglossum Rafinesque, the cut-lip. Proc. Biol. Soc. Wash., xxiv, p. 2r3. Scale resembling that of Mylocheilus.

Gila Baird \& Girard, the bony-tail. Biological Bulletin, xx, p. 374, pl.v, fig. 30 (scale of young $G$. robusta); Girard, Ichth. Mex. Boundary Surv., p1. xxIv, fig. Io-I2 (grahami=robusta); p1. XxxIII, fig. 8-ro (emorii=elegans). The mature scale is more or less elongate, with a distinct basal lobe, the base being in general like that of the shorter scale of Lavinia. A Gila about $91 / 2$ inches long, collected by Messrs. E. R. Warren and J. W. Frey in the Bear River at Lily, Routt County, Colo., June 30, r909, appears to be G. seminuda Cope \& Yarrow. The caudal peduncle is almost $\mathrm{I}_{3} \mathrm{~mm}$. in depth, the base of the caudal fin $20 \mathrm{~mm}$. The fish is a typical Gila, and G. seminuda appears to have been based on an immature specimen. The ventral surface is without scales. Peritoneum rather dilute black, not spotted. Posterior division of air bladder large and broad, its breadth I6 $\mathrm{mm}$. Scales in lateral line about 96 ; the scales are elongate, with parallel, even concave sides;

$$
89970^{\circ}-13-2
$$


Richardsonius gibbosus is figured by Girard as having radii all around the scale, apical, lateral, and basal, and a scale from the abdominal region has a polygonal pattern in the nuclear field. According to the scales, therefore, this fish agrees with Temeculina. Placed in Richardsonius, the name gibbosus (Gila gibbosa Baird \& Girard 1854) has priority over nigra Cope 1876 , and intermedia Girard I856, the latter said by Gilbert \& Scofield (I898) to be identical. The name gibbosus is not a homonym if the fish is not placed in Leuciscus. According to Girard's figures, $R$. pulchellus has occasional poorly defined basal radii, but the whole appearance is very different from that of $R$. gibbosus. The scale of $R$. intermedius (there regarded as distinct from gibbosa or nigra) was briefly described in Proceedings of the Biological Society of Washington, volume XxIr, page I59, and was found to fall in the same immediate group as $R$. pulchellus (nigrescens); this does not agree with Girard's figures of gibbosus, but certainly his scales came from a much older fish. It remains to be seen whether $R$. intermedius is really distinct from gibbosus, but in view of the facts stated it will probably be best to follow Jordan \& Evermann in so treating it. There is, however, a further complication arising from the publication of Gila gracilis Baird \& Girard 1853 , which Gilbert \& Scofield ( 1898 ) say is not G. robusta, but is "Leuciscus intermedius." The name gracilis is not a homonym if the fish is not referred to Leuciscus, and it has priority even over gibbosus, so that in any event Richardsonius gracilis (Baird \& Girard) must be a valid specific name. Another change of nomenclature is required in the case of Richardsonius alicice. The name Tigoma gracilis Girard I856, is not available; but Squalius copei Jordan \& Gilbert I880 is and the species becomes Richardsonius copei (Jordan \& Gilbert).

Rutilus auctt. Amer.=Myloleucus.

Semotilus Rafinesque, chub. Proc. Biol. Soc. Wash., xxI, p. I62, p1. III, fig. 4 (S. corporalis and $S$. atromaculatus). A western form of S. atromaculatus, obtained by Mr. H. G. Smith at Julesburg and Sterling, Colo., appears to be subspecifically distinct and may be known as S. atromaculatus macrocephalus (Girard). In its scales it approaches S. corporalis.

Siphateles Cope. Proc. Biol. Soc. Wash., xxII, p. I6I (as Rutilus olivaceus); t. c. p. 2 I 7.

Tiaroga Girard. Girard, Ichth. Mex. Boundary Survey, pl. xxvin, f. I2-I4. The scales have radii all around, and are transversely oval in form, altogether in the manner of Chrosomus.

Although there is still much to be learned about the scales of American Cyprinidæ, the facts discussed above indicate very well that our fauna is essentially distinct from that of the Old World, with, however, the nearest allies of Old World types mostly in the far West; also, I believe that any fundamental separation of our genera into an herbivorous group with long intestine and a mainly carnivorous one with short intestine is artificial. The herbivorous group is to be divided into several which seem to be properly associated with corresponding groups in the carnivorous series.

\section{(B) OLD WORLD GENERA.}

My material representing Old World Cyprinidæ is almost wholly from the British Museum, which is herein abbreviated to $\mathrm{B}$. M.

Abramis Cuvier, breams. Proc. Biol. Soc. Wash., xxm, p. 2II-2I3; Zool. Anzeiger, Xxxvi, p. 478, fig. 3 (A. elongatus).

Acanthorhodeus Bleeker. A. tenianalis is a very deep-bodied fish from Shanghai (Swinhoe, B. M.); the scales, as usual in the Rhodeines, are extremely broad; length a little over 5 mm., breadth fully 8. The basal circuli are dense, those at the sides more widely spaced; the very numerous radii, all apical, are wavy, or more or less zigzag. The region of the radil is finely striate with lines of growth, and in the interradial spaces are spots due to a kind of pitting. (P1. xxxI, fig. 2.) Zool. Anzeiger, xxxvi, 477.

Alburnus Heckel, bleak. Zool. Anzeiger, xxxvi, p. 477. (A. lucidus and filippii.)

Amblyrhynchichthys Bleeker. A. truncatus from the Menam River, Siam (Royal Siamese Museum; B. M.), has subquadrate scales with very thin apical margins; length about $3 \frac{1}{2}$, with slightly over 
$4 \mathrm{~mm}$; nucleus well basad of middle; laterobasal corners very distinct; basal margin thrown into two or three prominent folds; basal radii few, delicate and irregular; apical radii about ten, very slender, the outer ones broad outward; apical area with growth striæ, but free from circuli (here agreeing with Gobio, Saurogobio, etc.); circuli very numerous, the lateral ones more widely spaced. The outline of the scale, especially the basal part, is practically as in Barbus mahecola (Biol. Bull., Xx, p1. III, fig. I9), but the sculpture more resembles that of Gobio and its allies.

Aspidoparia (Heckel) Bleeker. Zool. Anzeiger, xxxvin, p. 87, fig. 5 .

Ballerus Heckel. Proc. Biol. Soc. Wash., XxII, p. 212-2I3.

Barbichthys Bleeker. Zool. Anzeiger, XxxvI, p. 252, fig. 2 and 3. The scale of B. lavis from Siam is large, about ro $\mathrm{mm}$. long and 8 broad, with prominent though rounded laterobasal corners; basal margin thrown into two broad wave-like lobes; a single, median, basal radius; numerous apical radii, but only about four, which are strong, reaching the nuclear area, whereas in the marginal region there are over 30 ; apical field with the circuli broken up, forming pustules; lateral and basal circuli dense and regular. The figures in the Zoologischer Anzeiger show the relation of the circuli to the pustules.

Barbus Cuvier \& Valenciennes, barbel. Proc. Biol. Soc. Wash., XxIr, p. I57-I 58; XxIII, p. I45-148, pl. III, fig. I (B. chrysopoma), fig. 3 (batesii), fig. 4 (barbus), fig. 5 (ksibi), fig. 6 (pleurotaenia), fig. 9 (grahami); Zool. Anzeiger, XxxvI, p. 479; Biol. Bulletin, Xx, pl. III, fig. I9 (mahecola); Boulenger, Catalogue Freshwater Fishes of Africa, vol. II, p. 2, fig. I (bynni, pleurogramma, perince). The Barbus compressus mentioned in Proc. Biol. Soc. Wash., XxIII, p. I46, is from Fort Stedman, Shan States, 3,000 feet (E. W. Oates; B. M.). This is B. compressus Boulenger, Ann. Mag. Nat. Hist., ser. 6, XII, I893, p. 202; not B. compressus Day, Proc. Zool. Soc. Lond., I869, p. 555. With Dr. Boulenger's permission, I alter $B$. compressus Boulenger to $B$. compressiformis n. $\mathrm{n}$.

Barilius Hamilton Buchanan. Proc. Biol. Soc. Wash., XXIII, p. I43-I44, p1. III, fig. Io (B. loati).

Barynotus Günther. I believe this generic name is preoccupied in Coleoptera. B. luteus from Schiraz (Marquis Doria; B. M.) has very large reddish quadrate scales, about $13 \mathrm{~mm}$. long and broad; nucleus about $5 \mathrm{~mm}$. from base; circuli very fine, about Io or I2 basal radii and about 35 apical ones, the latter wavy and many of them imperfect. In size, color, and form this is like the scale of Semiplotus macclellandi, except that the latter is considerably broader than long. In detail there are rather important differences, though of degree rather than of kind. In the Semiplotus the basal radii are very few and weak, while there are numerous delicate but distinct lateral radii, represented only by a few irregular lines in Barynotus. In both the apical radii are wavy and the interradial spaces are tuberculate, but the tubercles are more prominent in Semiplotus and extend almost to the nucleus, whereas in Barynotus they do not go beyond the skin-covered area.

Capoeta Valenciennes. (P1. xxxiv, fig. 13.) Proc. Biol. Soc. Wash., xxiIr, p. I49. According to Berg, C. steindachneri Kessl is a synonym of $C$. heratensis Keyserling.

Carassius Nilsson, goldfish. Zool. Anzeiger, xxxvi, p. 480.

Catla Cuvier \& Valenciennes. Catla catla (Cyprinus catla Hamilton Buchanan; Catla buchanani Cuvier \& Valenciennes) from Calcutta (F. Day; B. M.) has large elongate scales with rectangular basal corners; length II, breadth $8 \mathrm{~mm}$. The nucleus is about $4 \frac{1}{2} \mathrm{~mm}$. from the base; the base has five or six irregular but prominent radial folds; apical radii about 16 , delicate, straight, many incomplete; lateral radii variable, when distinct similar to those of Semiplotus; basal circuli irregular and not so dense as usual; apical circuli distinct, longitudinal, the inner ones directed more or less mesad, approaching the condition so well developed in Cirrhina jullieni, but not nearly so extreme. According to Day, Catla catla reaches a length of at least 6 feet; my material is from a much smaller fish.

Chanodichthys Bleeker. C. pekinensis from Shanghai (Swinhoe; B. M.) has rather large broad-oval scales, about Io $\mathrm{mm}$. long and slightly over 8 broad; nucleus nearly central; circuli finely evanescent in the apical region, which is somewhat rugose; no basal or lateral radii, but about 2 I apical, some incomplete. The scale examined is not symmetrical and probably not quite normal.

Chela Hamilton Buchanan. (P1. xxxir, fig. 4.) Proc. Biol. Soc. Wash., xxiri, p. I42, pl. III, fig. I2 (C. argentea).

Chelathiops Boulenger. Proc. Biol. Soc. Wash., xxIII, p. I4I-I42, pl. III, fig. II (C. bibie). 
Chondrostoma Agassiz. (P1. XxxI, fig. 5.) Proc. Biol. Soc. Wash., XxI, p. 210; Zool. Anzeiger, XxxVI, p. 477 .

Cirrhina Cuvier. Proc. Biol. Soc. Wash., xxmI, pl. III, fig. 8 (C. jullieni). The scales of four species of Cirrhina, obtained from the British Museum, are so distinct as to suggest that they can not all be truly congeneric.

Scale much longer than broad (length 9 , breadth $7 \mathrm{~mm}$.) with broadly rounded apex and squared base; circuli fine, wanting in the apical field, where they are replaced by coarse tubercles; basal radii about a dozen, delicate, many incomplete; apical radii few and irregular; nucleus a short distance basad of middle (Cutch, F. Day) ............. . mrigala Hamilton Buchanan

Scale slightly longer than broad, or about as broad as long.

Scale $9 \mathrm{~mm}$. long, $8 \mathrm{I} / 2$ broad; laterobasal corners distinct; nucleus considerably basad of middle; no basal radii; apical radii over 20, mostly well formed; circuli replaced by transversely elongate tubercles in the apical region covered by skin, but in the central region below this by vermiform markings ..................... chinensis Günther (Haslar collection).

Scale $5^{\mathrm{T}} / 4 \mathrm{~mm}$. long, $4^{3} / 4$ broad; laterobasal corners distinct; nucleus very far basad; a few weak submedian basal radii; apical radii about eight, distinct, wide apart; apical circuli very distinct, wide apart, sloping toward the middle (Stung-Strang, Paris Museum).

C. jullieni (from type lot)

Scale conspicuously broader than long (length $23 / 4$, width $3 \frac{1}{2} \mathrm{~mm}$.); nucleus far basad; basal radii about 20 , very short, submarginal; apical radii over 20 , not or hardly converging; circuli absent in apical region, but a small amount of tuberculation; broad nuclear area with fine very irregular reticulation; probably latinucleate scales (Kushk, Afghan Boundary Commission.

C. afghana Günther

The scales of Cirrhina are in general (excepting C. afghana) much like those of Osteochilus or Labeo. Thus, as regards the sculpture of the apical field, $C$. jullieni may be compared with Labeo chrysophekadion, while $C$. mrigala and $C$. chinensis may be compared with Labeo sindensis, etc. May we not suppose that the groups of Osteochilus and Cirrhina have arisen from different groups of Labeo?

Cosmochilus. I have a lateral line scale of C. falcifer, a very large fish from Sarawak, Borneo (C. Hose; B. M.). The scale is of the quadrate type, strongly orange tinted, about $20 \mathrm{~mm}$. long and broad; lateral line canal bifid at the apical end; nuclear field extremely large, granular; basal radii very numerous, but wholly marginal and submarginal; apical radii very numerous, irregular, wavy; no circuli in apical field. C. harmandi from the Menam River, Siam (Royal Siamese Museum; B. M.) is represented by much smaller, pallid scales, about $7 \mathrm{~mm}$. long and 6 broad, but of the same subquadrate form. Both basal and apical radii are fewer and more irregular, the basal longer, the apical wavy. Except for the size and minor details, the scales of the two species are wholly of the same type.

Crossocheilos Bleeker. (Crossochilus auctt.) I follow the British Museum labels, but Day refers $C$. latia and C. reba to Cirrhina. The scales before me are separable as follows:

Scales large and elongate (length about II I $/ 2 \mathrm{~mm}$., breadth about $6 \mathrm{I} / 2$ ), parallel-sided; circuli dense, those of the apical field transformed into tubercles in part, but toward the nucleus into vermiform lines, and in the extreme apical region wholly wanting; nucleus only about $3 \mathrm{~mm}$. from base; three or four distinct basal folds; apical radii numerous, more or less wavy, converging toward the middle; lateral radii delicate, variable, usually distinct (Madras, F. Day; B. M.).

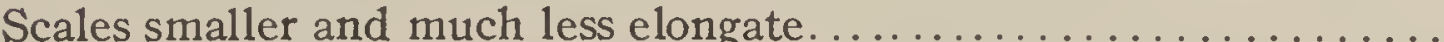

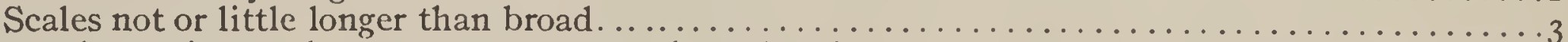

2. Basal margin gently convex, not wavy; laterobasal corners more rounded; basal radii very few and feeble; apical radii numerous, parallel; scale (not adult) about $5 \frac{1}{2} \mathrm{~mm}$. long and 4 broad (Simla, F. Day; B. M.) ............................ latia (Hamilton Buchanan)

Basal margin wavy or broadly crenate; laterobasal corners sharper; basal radii very irregular, but distinct; apical radii numerous, many imperfect; nucleus about $\mathrm{I} / 2 \mathrm{~mm}$. from base; scale about $7 \mathrm{~mm}$. long and 6 broad. (Java; B. M.)...................... oblongus

3. Nucleus less basad ( $13 / 4 \mathrm{~mm}$. from base in scale $5 \mathrm{~mm}$. long and $4 \mathrm{~T} / 2$ broad); middle interradial (apical) region strongly tuberculate (Ningpo, F. W. Styan; B. M.).... S. styani Boulenger Nucleus more basad; middle interradial region not tuberculate (Cashmere, T. C. Jordon; B. M.) 
C. reba seems to stand apart from the others. Day says of $C$. latia, "this fish has much the character of a loach or of a Discognathus, adhering to stones in the beds of rivers." Superficially the scales of $C$. reba look like those of Rohita lineata, but they are very different in detail, having a different apical field and the nucleus very much more basad than in Rohita.

Culter. This genus has rather small (about $4 \mathrm{~mm}$. diameter) circular scales, with a central nucleus, rather few and weak apical radii, and no basal. The basal circuli are very dense. I have two species from the British Museum; C. ilishaformis from Kiu Kiang (Styan) and C. erythropterus Basilewsky from the River Keroulen, Mongolia (Chaffanjon). They are very much alike, but in erythropterus the apical radii are more distinct, and the apical margin is crenate. (Pl. XxxIV, fig. I4.)

Cyprinus Linnæus, carp. Zool. Anzeiger, xxxvi, p. 480, fig. 2 (p. 478). The figure represents the hybrid C. kollarii.

Dangila Cuvier \& Valenciennes. From the British Museum I have the scales of three species:

Scales large, much longer than broad (length $16 \mathrm{~mm}$., breadth $\mathrm{Io}$ ); strongly orange-tinted; parallelsided; nucleus far basad; weak radii all around; middle apical region strongly tuberculate (in a deep place in the cavery, Salem, Capt. Mitchell) .................... leschenaultii

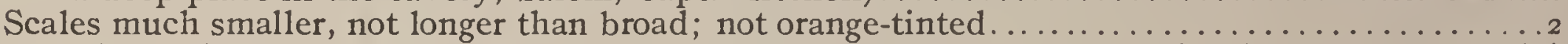
I. Apical field distinctly tuberculate; scale about $5 \mathrm{~mm}$. long and broad. (Deli, Sumatra, Moesch.) D. kuhlii (cf. Zool. Anzeiger, XXXVI, p. 478, where for gobiiform read gobioniform.)

Apical field merely striate; scale about $7 \mathrm{~mm}$. long and broad (mouth of Patani River, Annandale

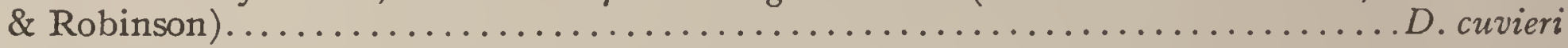

Danio Hamilton Buchanan. Type of subfamily Danioninæ. Zool. Anzeiger, xxxvirI, p. 85, fig. I, 2; (D. devario and D. cequipinnatus.)

Diptychus Steindachner. D. maculatus Steindachner from Nepaul (F. Day; B. M.) was examined, but no scales were found; the skin is very thickly beset with small spots of ferruginous pigment. According to Day, there are small scattered scales, which I evidently overlooked.

Discognathus Heckel. Proc. Biol. Soc. Wash., xxiI, p. I49-I5O. The species described belong to the subgenus Garra Hamilton Buchanan.

Engraulicypris Günther. Neobola Vinciguerra is now regarded by Boulenger as a synonym. Proc. Biol. Soc. Wash., XXIII, p. I43 (Neobola) and I44.

Gnathopogon Bleeker. I have examined G. gracilis (Capoeta gracilis) from Superghan, Nalzow Chai River (R. T. Günther; B. M.), and have given some account of it in Proc. Biol. Soc. Wash., xxIII, p. I 49. The scales are about $4 \frac{1}{3} \mathrm{~mm}$. long and $33 / 4$ broad; nucleus well basad of middle; laterobasal corners prominent; basal radii irregular, few and very feeble apical radii distinct, about I5, with strong tubercles between.

Gobio Cuvier, gudgeon. Zool. Anzeiger, xxxvi, p. 477-478; Biol. Bulletin, xx, pl. v, fig. 27 .

Gymnocypris Günther. I examined G. waddellii Regan (Yamdok Lake, Tibet, I4,800 ft., L. A. Waddell; B. M.) but found no scales. The skin is sepia brown with darker, reddish dots.

Hemibarbus Bleeker, Proc. Biol. Soc. Wash., XxIII, p. I46-I47 (under Barbus). According to L. S. Berg, H. barbus or schlegeli is to be called H. labeo (Cyprinus labeo Pallas), with maculatus (Bleeker) as a variety.

Hypophthalmichthys Bleeker. In Günther's Catalogue this is considered typical of a distinct section or subfamily, Hypophthalmichthyina, or as we should now say, Hypophthalmichthyinæ. I examined $H$. nobilis from Shanghai (Swinhoe; B. M.), but by an unfortunate accident the scale was lost when in the hands of the photographer.

Ischikauia Jordan \& Snyder. Zool. Anzeiger, xxxvIII, p. 86, fig. 3.

Labeo Cuvier. Proc. Biol. Soc. Wash., xxiII, p. I50-I5I, pl. III, fig. 2 (L. fimbriatus), fig. 7 (L. senegalensis); Biol. Bulletin, vol. xx, pl. I. fig. 8 (L. sladoni).

Leptobarbus Bleeker. L. hoevenii (Tinjar River, 200 miles from the sea, C. Hose; B. M.) is a fish with terminal mouth, having very large quadrate scales, my specimen IS mm. long and $\mathrm{I} 4$ broad. The basal radii, about $\mathrm{I}_{4}$, are very delicate and irregular; lateral radii more or less developed; apical radii about 33 ; circuli evanescent apically. (P1. xxxIV, fig. I5.) 
Leptocypris Boulenger. Proc. Biol. Soc. Wash., xxmr, p. I44.

Leuciscus Cuvier, dace, chub, etc. Proc. Biol. Soc. Wash., XxII, p. 21 5-2 I6 (including not only Leuciscus proper, but also Rutilus Rafinesque, Pigus Bonaparte, Cephalus Bonaparte, Idus Heckel, and Scardinius Bonaparte); Zool. Anzeiger, xxxvr, p. 479-480; Biol. Bulletin, xx, p. 37I, pl. I, fig. 7 ( $L$. illyricus), p1. II, fig. Io (L. rutilus), fig. II (L.friesii), fig. I2 (L. hakuensis), fig. I3 (L. jouyi).

Leucogobio Günther. I have L. mayede (Jordan \& Snyder) from Lake Biwa, Japan (Jordan \& Snyder). The scales are much broader than long (length about $3^{1 / 2} \mathrm{~mm}$., breadth $5 \frac{1}{3}$ ), but otherwise entirely of the type seen in Gobio, with the same radii, circuli, etc.

Luciosoma Bleeker. I have three species from the British Museum. The scales are large and subquadrate; basal, lateral, and apical radii distinct, the lateral oblique, not or hardly at all directed toward the nucleus, except when the lower end is abruptly bent and turned inward; circuli very fine, but absent in the granular or striate apical field; laterobasal corners distinct. The species are separated thus:

Nucleus central or nearly; scale $13 \mathrm{~mm}$. long and Io broad; about Io apical radii; fish with dorsal fin very far back (W. Siam, Carl Bock).................................. harmandi

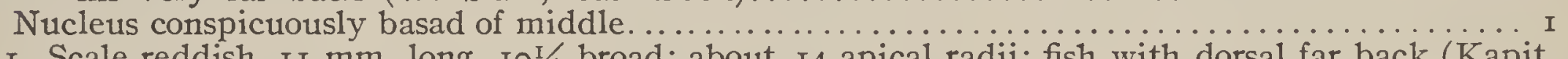

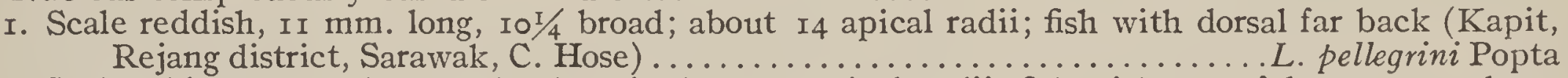
Scale white, $8 \mathrm{~mm}$. long and 7 broad; about 14 apical radii fish with row of large spots down side (Upper Baram River, C. Hose) .............................. trinema

In scale characters the genus is very compact and except for the difference in the position of the nucleus the characters cited may not be specific. Scales of L. trinema are figureu on plate xxxirr, figure 7 .

There is a rather strong resemblance between the scales of Luciosoma and Leptobarbus hoevenii, but in Luciosoma the apical radii are spreading, fanlike. in the Leptobarbus they are parallel.

Macrochirichthys; see Chela macrochir; Proc. Biol. Soc. Wash., xxIII, p. I42. Fowler (I905) treats Macrochirichthys as a distinct genus.

Myloleucus Günther. Cope published a genus of the same name at about the same time, but I believe the American genus has priority. $a$ M. athiops, from Kiu-Kiang (Styan; B. M.), has large scales, approximately circular, but with more or less evident laterobasal angles; length I2, breadth I I mm.; nucleus central; area covered by skin unusually large, extending to nucleus, skin densely speckled with red-brown pigment; basal circuli quite dense; slight basal folds, but no radii; apical radii about a dozen, feeble; apical circuli strong, longitudinal, converging toward the middle, where they meet at very acute angles. A scale approaching the type of Cirrhina jullieni.

Neobola Vinciguerra; see Engraulicypris.

Opsariichthys Bleeker. Zool. Anzeiger, xxxvi, p. 252, fig. I (O.morrisonii); xxxvIII, p. 87. The species figured is now to be referred to $Z \bar{a} c c o$.

Oreinus McClelland. (P1. xxxiv, fig. I6.) A genus of mountain fishes with small scales, circular or broad-oval or (grahami) sometimes subtrigonal, with nucleus central or nearly, circuli not very dense and rather widely spaced radii all around. They are therefore of the general type of Chrosomus and Phoxinus. The genus on scale characters is quite compact. Three species have been examined in the British Museum:

O. grahami. Tongchuenfu, Yunnan (J. Graham). Scales 2 to $2 \frac{1}{4} \mathrm{~mm}$. diameter.

O. plagiostomus (Heckel) Assam (F. Day). Scales about I by $3 / 4 \mathrm{~mm}$.

O. richardsonii (Gray \& Hardwicke) Nepal (B. H. Hodgson). Scales a little smaller than those of O. grahami. This genus is referred to the Schizothoracinæ.

Osteobrama Heckel. Day calls this genus Rohtee. Dr. G. A. Boulenger writes (litt., May, I9ro): "Rohtee Sykes and Osteobrama Heck. are synonyms. Both genera were established in the same year. I don't know which has really priority." I have four species from the British Museum.

$a$ Dr. D. S. Jordan kindly informs me that Cope's name has about a year's priority. Myloleucus Günther may be changed to Myloleucops n. n., our fish becoming Myloleucops aethiops. 
Scales elongate ( $8 \mathrm{~mm}$. long, slightly over $3 \frac{1}{2}$ broad), parallel sided, nucleus $2 \mathrm{~mm}$. from anterior end; posterior end broadly and shallowly emarginate; circuli fine and dense; a single delicate radial line runs down the middle of the scale from the nucleus to the posterior margin, but otherwise there are no basal radii; apical field rugose, with very weak radii (Sittang River,

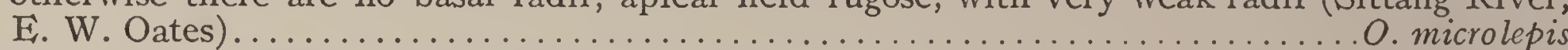

Scales circular or nearly; nucleus nearly central; no basal radii, but the basal region more or less

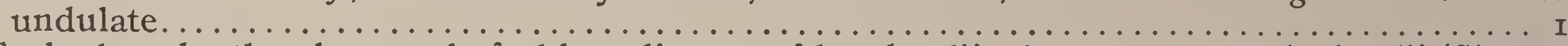

I. Scales broader than long; only feeble rudiments of basal radii; about $\mathrm{I}_{3}$ wavy apical radii (Sittang

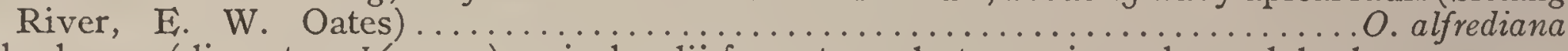

Scales larger (diameter $4 \frac{1}{2} \mathrm{~mm}$.); apical radil few, strong but very irregular and broken, wavy; a very deep-bodied fish (Sittang River, E. W. Oates) ............... O. feae Vinciguerra

Scales smaller (diameter about $3 \mathrm{~mm}$.), apical field without circuli, but with weak and broken wavy radii (Sittang River, E. W. Oates)............... cotio (Hamilton Buchanan)

The last three seem closely allied, but $O$. microlepis is very different and is probably not truly congeneric. In Günther's Catalogue Osteobrama stands next to Chanodichthys. The scale of Chanodichthys, without basal radii, is in fact of a similar type, but much larger, with the numerous apical radii not distinctly wavy.

Osteochilus Günther. Zool. Anzeiger, xxxvi, p. 253, fig. 4 (O. kahajanensis). I have seven species from the British Museum, which are separable thus:

Apical interradial area striate with longitudinal converging circuli................ I

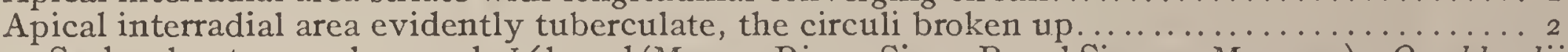

I. Scales about $7 \mathrm{~mm}$. long and $5 \frac{1}{2}$ broad (Menam River, Siam; Royal Siamese Museum). . O. schlegelii Scales about $4 \mathrm{~mm}$. long and $3-3 \frac{1}{4}$ broad (Menam River, Siam; Royal Siamese Museum).

Scales very large, is mm. long and $x_{3}$ broad; apical radii wavy, basal radii very few and irregular (Baram River, Sarawak; C. Hose)................. hasseltii (Cuvier \& Valenciennes)

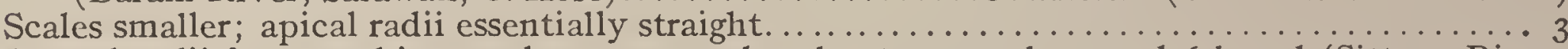
Lateral radii few, reaching nuclear area; scales about $7 \mathrm{~mm}$. long and 6 broad (Sittang River;

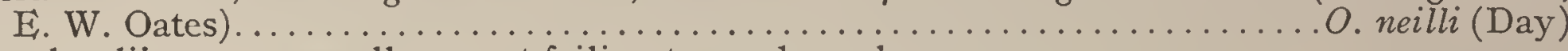
Lateral radii numerous, all or most failing to reach nuclear area.................. 4. Basal margin strongly trilobed (Deli, Sumatra; Moesch) .......................... Basal margin weakly undulate. . . . . . . . . . . . . . . . . . . . . . . . . . 5 5. Scale about Io $\mathrm{mm}$. long and 9 broad; skin pale with dark dots. (Baram district; C. Hose).

O. kahajanensis
. Scale about $7 \mathrm{~mm}$. long and 6 broad; skin brown (Tinjar River, 200 miles from sea; C. Hose).

O. vittatus

All are broadly rounded apically, essentially truncate basally, with evident laterobasal corners; nucleus far toward the base (least so in $O$. neilli); apical radii well developed, basal very poorly, feeble and irregular. The genus is a compact one on the scales, and the specific distinctions given are probably not all valid. (See also remarks under Cirrhina.)

Paracheilognathus Bleeker. Proc. Biol. Soc. Wash., xxIr, p. I57; Zool. Anzeiger, xxxvi, p. 477. Scales of $P$. rhombcus are about $23 / 4 \mathrm{~mm}$. long, $43 / 4$ broad; circuli not at all dense.

Parapelecus Günther. P. argenteus from Kiu-Kiang (Styan; B. M.) is a remarkable fish, with the scales inserted obliquely, and the lateral line abruptly bent. The scales are about $4 \mathrm{~mm}$. long and $63 / 4$ broad, covered with thin skin to the base. There are fine basal circuli, but no basal radii; in the apical field the circuli are wanting, but there are numerous irregular delicate radii. Thus the scale combines the shape of the Rhodeines with the sculpture of the Gobio group. Except for the larger size and covering of pinkish skin, the scales are extremely like the broader ones of Leucogobio mayedce.

Phoxinellus Heckel. Proc. Biol. Soc. Wash., xxII, p. 216. The locality given as Oued el Mahd should be Oued (or Wed) el Mahdi; the printer took the $\mathrm{i}$ for a semicolon. The two lots of scales represented Phoxinellus chaignoni (Vaillant) and P. callensis (Guichenot), which Boulenger now regards as distinct, though very closely allied. I fail to find any difference in the scales of the two.

Phoxinus Rafinesque. Proc. Biol. Soc. Wash., xxir, p. I86 and p. 2 I6; Zool. Anzeiger, xxxvi, p. 476. Pseudogobio Bleeker. Zool. Anzeiger, xxxvi, p. 478, fig. I (P. esocinus Schlegel).

Rasbora Bleeker. Proc. Biol. Soc. Wash., XXIII, p. I44. 
Rhinogobio Bleeker. Biol. Bulletin, xx, p.37I, pl. II, fig. 9. Scale elongate, with broad truncate base. Rohita Valenciennes. R. lineata from the Sittang River (E. W. Oates; B. M.), has elongated scales, about Io $\mathrm{mm}$. long and $6 \mathrm{r} / 2$ broad, the truncate base with a broad median lobe, bounded by the basal radii, which are two or three in number. Nucleus a short distance basad of center; gently curved delicate lateral radii; apical radii evanescent or extremely feeble; skin-covered area strongly tuberculate. The shape of the scale is very like that of Labeo fimbriatus. (P1. xxxII, fig. 9.)

Saurogobio Bleeker. Zool. Anzeiger, xxxvi, p. 478. Scales elongated; those of S. dumerilii much like those of Rhinogobio typus; both species collected by Styan at Kiu-Kiang.

Scaphiodon Heckel. Scales broader than long, with small subbasal nucleus; apical radii numerous, but no basal ones; interradial area tuberculate. I have two species from the British Museum, very much alike, but separable as follows:

Base with a very prominent rounded lobe; laterobasal corners very distinct; skin pallid, speckled with light brown (Sind; F. Day) ................................. Day

Basal margin convex, but not lobed; laterobasal corners indistinct; skin brown, speckled with darker (Muscat, Arabia; A. S. G. Jayakar)............................ muscatensis

Except for the broader scales and denser sculpture there is an evident resemblance to Capoeta. This resemblance doubtless extends to other than scale characters, for Cuvier and Valenciennes included species of Scaphiodon in Capoeta. S. muscatensis is figured on plate xxxiI, figure ro.

Scaphiodontichthys Vinciguerra. My two scales of S. burmanicus, from Mount Mooleyit (Fea; B. M.), are both latinucleate; the scale is broader than long (about 7 by $8 \mathrm{~mm}$. ), considerably larger than that of Scaphiodon, with numerous apical radii but no basal; the basal margin is convex, without any lobe, and without laterobasal corners. The scale is structurally close to that of Scaphiodon.

Schizopygopsis Steindachner. I microscopically examined the skin of S. stoliczkae (Seistan, Helmund River, Col. McMahon; B. M.) and S. younghusbandi (Lhasa, Tibet, H. J. Walton; B. M.), but found no scales. The skin in $S$. younghusbandi is clear, profusely dotted with lichenoid spots of dark brown pigment.

Schizothorax Heckel. Biol. Bulletin, xx, pl. IV, fig. 22 (S. biddulphii); Zool. Anzeiger, xxxvi, p. 476. In S. intermedius (Kashgar; B. M.) the scales are elongate as in S. biddulphii, and the sculpture is in all respects the same, except that it is less dense. (P1. XxxiI, fig. II.)

Semiplotus Bleeker. In Semiplotus semiplotus (Cyprinus semiplotus McClelland, Semiplotus macclellandi Bleeker) from Assam (F. Day; B. M.) the scales are quite large, reddish, broader than long (length $\mathrm{I}_{3}$, breadth ${ }_{5} \mathrm{~mm}$.); nucleus a short distance below the middle; basal radii 3 or 4 , feeble; slender curved lateral radii; apical radii very numerous, wavy; apical field coarsely tuberculate. The scale is of entirely the same general type as that of Barynotus luteus, but shorter, with much less prominent laterobasal corners, and fewer and feebler basal radii. The color is the same in both, and the differential characters cited are doubtless more or less variable. (P1. xxxIr, fig. I2.)

Squaliobarbus Günther. Biol. Bulletin, xx, p. 37I, p1. I, fig. 6 (S. curriculus).

Tinca Cuvier. Zool. Anzeiger, xxxvi, p. 476; Biol. Bulletin, xx, p. 373, pl. IV, fig. 2 I.

Tylognathus Heckel. Day treats this as a synonom of Labeo. I have five species from the British Museum. They agree in having numerous apical radii and the apical field tuberculate. So far as the material goes, they appear to be separable as follows:

The subquadrate scale broader than long (about $7 \mathrm{~mm}$. long and 8 broad); laterobasal corners very prominent; basal radii very numerous, but fine and irregular; apical radii strong, more or less wavy, the interradial tubercles very strong ..................T. " Lobocheilus") lehat

The subquadrate scale a little longer than broad (about $8 \mathrm{~mm}$. long and $71 / 2$ broad); general characters like the last, but apical radii scarcely wavy, and interradial tubercles weaker (Pata R.;

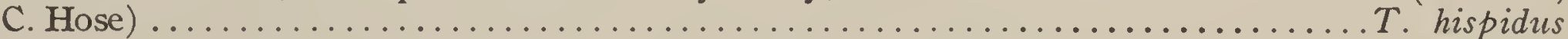

Scale conspicuously longer than broad, parallel-sided, shape like that of Labeo fimbriatus........ I

I. Scale about I $2 \mathrm{~mm}$. long and 8 broad (Bowany R.; F. Day)............... . ariza (Buchanan) Scale about $7 \mathrm{~mm}$. long and 4 broad, but fish not adult (Madras; F. Day)..T. boga (Buchanan) Scale about $5 \frac{1}{3} \mathrm{~mm}$. long and $3 \frac{1}{2}$ broad (Poona; Lieut. Col. Playfair)........... T. striolatus

The following Asiatic Labeo have scales of the Tylognathus type, or approximating it; L. sindensis, L. falcatus, L. bicolor, L. sladoni, L. ricnorhynchus, L. kontius (nearly shape and size of $T$. ariza, but less 
elongate), L. leschenaultii (looks like $T$. ariza, but differs by strong basal radii, which are entirely absent in $T$. ariza), L. bata (quite like $T$. ariza, with no basal radii), L. pangusia, L. nigripinnis, L. kawrus, L. microphthalmus. Several others approach the same type quite closely, and it is evident that so far as the scales go, Tylognathus can not be separated from Labeo.

Varicorhinus Ruppell. Proc. Biol. Soc. Wash., xxIII, p. I48.

Xenocypris Günther. Zool. Anzeiger, Xxxvi, p. 253, fig. 5 (X.argentea). I have two species from the British Museum, both having pale subcircular scales.

Scale about $5 \frac{1}{2} \mathrm{~mm}$. long and $5 \frac{3}{4}$ broad; laterobasal corners rounded; no basal radii; circuli in interradial (apical) region strong, transverse; nucleus almost central (Kiu-Kiang; Styan).

Scale about $32 / 3 \mathrm{~mm}$. long and $31 / 2$ broad; laterobasal corners more evident; no basal radii. apical radii 7 or 8 , the interradial circuli transverse, strong, widely spaced; nucleus far basad of middle (mountain streams near Kiu-Kiang; Styan)................ argentea Günther

In the apical field there is a strong resemblance to Chondrostoma, but that genus has well-

developed basal radii. See also Zool. Anzeiger, xxxvin, p. 86.

Zacco Jordan \& Evermann. Zool. Anzeiger, xxxviII, p. 86, fig. 4.

CATOSTOMIDE. Suckers and buffalo-fishes.

The scales of the Catostomidæ are usually quite large, and resemble those of the Old World Cyprinidæ in most respects. For figures see Proceedings Biological Society of Washington, volume XXII, page $I_{5} 8$, figure 2 (Catostomus griseus; the figure is printed upside down); Biological Bulletin, volume $\mathrm{xx}$, plate I, figure 3 (Moxostoma aureolum), and figure 4 (Pantosteus santa-ance). In every case the basal radii are well developed. The scales of Moxostoma cervinum Cope, showing two types, one reticulated, are described in Science, July 28, r9i , page r26.

\section{Subfamily ICTIOBINÆ. Buffalo-fishes.}

In the carp sucker, Carpiodes velifer (Rafinesque), the scales from just below the front of the dorsal fin are broader than long, but those from between posterior end of dorsal and lateral line are longer than broad. The scales studied are from a fish about $4 \frac{7 / 8}{8}$ inches long, from the Wabash River, Indiana (Bureau of Fisheries). Apical margin broadly rounded; laterobasal angles distinct; base rounded, forming a single broad lobe, between which ard the laterobasal angles the margin is concave; circuli very distinct, in the apical field only about half as closely set as laterally and basally; apical radii few, usually three, one median, and a curved one on each side, but sometimes five are present; basal radii numerous, about 30 , or more counting imperfect ones, close together; nucleus central or almost. Latinucleate scales are coarsely and irregularly reticulate in the middle. Compared with the Catostomine series, this falls with Catostomus commersonii, from which it is at once separated by the character of the apical radii.

\section{Subfamily CATOSTOMIN必. Suckers.}

Scales very small; oval, oblong, or subcircular, without laterobasal corners................ I Scales larger, often very large, with evident laterobasal corners. . . . . . . . . . . . . . . . . . . .

I. Radii all around; nucleus more or less apicad of middle (Boulder County, Colo.).

Catostomus griseus (Girard)

Radii apical and basal, the lateral basal ones usually not pointing to the nucleus, but when complete strongly crooked above, the bent basal end then pointing to the nuelcus; nucleus

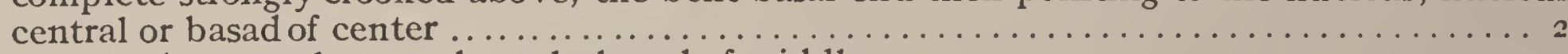

2. Nucleus nearly central, or moderately basad of middle $\ldots \ldots \ldots \ldots \ldots \ldots \ldots \ldots \ldots \ldots \ldots$ Nucleus far basad of middle of the very small scales (Russian River, Cal.; Stanford University.

Catostomus occidentalis Ayres

3. Scales often broader than long, but variable (Oregon) .............. macrocheilus Girard Scales longer than broad, but little different from the last (California). C. humboldtianus Snyder Scales closely resembling the last, but with lateral circuli more developed, so as to approach C. griseus, except for the more basad nucleus (California).....Pantosteus santa-ance Snyder (The tubercles in the upper lip are much more numerous in the Pantosteus than in Catostomus macrocheilus.) 
4. Lateral and apical (interradial) circuli about equally far apart, strictly transverse........ 5 Apical circuli conspicuously more widely spaced than latcral ....................6

5. Scale subcircular, about $4 \frac{\mathrm{T}}{2} \mathrm{~mm}$. diameter, with about 4 to 6 apical, and $\mathrm{I} 7$ to 20 basal (no lateral) radii (Little South Fork, Cumberland River, Ky.; P. H. Kirsch),

Lagochila lacera Jordan \& Brayton

Scale smaller, rather more quadrate, with very prominent laterobasal angles; radii very strong, apical 4 to 6 , basal 6 to 8 (Cherokee, Iowa; S. E. Meek).Placopharynx duquesnii (Le Sueur)

6. Basal radii very numerous, $\mathrm{I}_{2}$ in young scales, up to 20 or more in adult; center reticulated in latinucleate scales..........Catostomus commersonii (Lacépède), including C. teres Mitchill

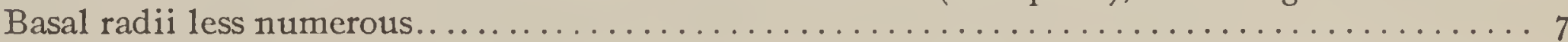

7. Basal radii more than $\mathrm{I} 2$; scale hardly differing from $C$. commersonii, but interradial circuli

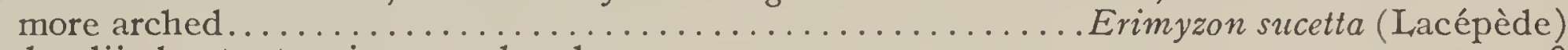

Basal radii about 7 to 9 in normal scales . . . . . . . . . . . . . . . . . . . . . .

8. With many incomplete apical radii..................................

With at most one or two incomplete apical radii...............ninytrema melanops (Rafinesque)

The scales of scveral of the above, but especially those of Lagochila, are quite of the type of Chondrostoma. It is evident that the scales of the American Catostomidx can be practically matched among the Palæarctic and Oriental Cyprinidæ, excepting only the western small-scaled group of Pantosteus and Catostomus griseus, occidentalis, etc. Even this exception is doubtful, for these smaller scales are certainly extremely like those of Oreinus, from Yunnan, Nepal, Assam, etc. It thus seems entirely impos. sible to find a scale character scparating the Catostomidx from the Old World Cyprinidæ. Decactylus Rafinesque, type Decactylus commersonii (Lacépède), or if Lacépède's fish is considered dubious, Decactylus teres (Mitchill), seems to be a valid genus, but Catostomus occidentalis, macrocheilus, etc., must be excluded from it.

COBITIDE. Loaches.

\section{Subfamily COBITIN}

The scales of this subfamily have been discussed in Proceedings of the Biological Society of Washington, volume $\mathrm{xxII}$, pages $205^{-206}$. The following genera are available for examination:

Cobitis Linnæus. T. c., p. 206 (C. tania).

Misgurnus Lacépède. T. c., p. 206 (M. fossilis, M. anguillicaudatus).

Somileptes (Swainson) Bleeker. T. c., p. 206 (Cobitis gongota).

Lepidocephalichthys Bleeker. 'T. c., p. 206 (L. berdmorei and L. guntea).

Acanthopsis Van Hasselt. A. chœrorhynchus (Bleeker) from Meetam, Tenasserim (Fea; B. M.) has scales which are much broader than long, with radii all around; transverse diameter less than half a millimeter. The scales are of the same general type as those of Cobitis trenia, and entirely different from the clongated scales of Somileptes and Lepidocephalichthys.

Subfamily HOMALOPTERINAE. East Indian loaches.

For Gastromyzon and Homaloptera (pl. xxxiv, fig. I7) see Proceedings Biological Society of Washington, volume XXII, pages 206 -207.

\section{KNERIIDE.}

Proceedings Biological Socicty of Washington, volume xxIr, page II 3 ; Biological Bulletin, volume $\mathrm{xx}$, plate $\mathrm{V}$, figure $3 \mathrm{r}$. (Kneria cameronensis Boulenger). This family falls here in Jordan's list, but in his two-volume work no justification for this position is found. Boulenger, having cxamined the skeleton of $K$. cameronensis, places the family between Phractolæmidæ and Cromeriidæ. Regan (IgII) places it near to Chanidæe, or milk fishes. It is an isolated type, and its scales are vcry peculiar.

\section{Suborder GYMNOTI. Electric eels.}

Dr. Max Ellis has in preparation a detailed paper on the scales of this group. He has very kindly allowed me to examine his series of slides in order to state the principal characters. Greatly to my surprise I find the scales to be quite different from those of the characinids known to me, but very similar 
indeed to those of such cobitids as Misgurnus and Lepidocephalichthys. They may also be compared with the small-scaled catostomids, as Pantosteus, or in Cyprinidæ with Oreinus. This general type of scale, with radii all around and a sort of latticework pattern, is, I believe, really primitive, with characters not very distantly approaching those of the amphibian Ichthyophis. It appears, therefore, that the gymnotids are not "degraded characinids" (Boulenger), but rather specialized pre-characinids. The fully developed radial pattern is found in the small-scaled gymnotids, the scale being nearly circular (Gymnotus carapo), or elongated (Sternopygus macrurus), or transversely oval (Hypopomus artedi). In Eigenmannia virescens more than half the scale is without radii, and if they all disappeared we should have a scale not very unlike that of the characinid Serrasalmo.

In the larger scales of Porotergus and Sternarchus the radii are very fine and the basal ones converge to the middle line, curiously simulating the condition found in some Gadidæ, as Urophycis.

\section{Order SCYPHOPHORI.}

For the Mormyridæ (including Gymnarchidæ) see Smithsonian Miscellaneous Collections, volume 56, no. 3. In Jordan's list the Haplochitonidæ and Galaxiidæ appear as Scyphophori, but this reference is opposed to the treatment in the earlier part of the book, and according to Regan (IgII) they are salmonoids.

\section{Order HAPLOMI.}

\section{ESOCIDE. Pikes.}

Esox (or Lucius) lucius from Toledo, Ohio (Rutter), has oblong scales about $3.5 \mathrm{~mm}$. long and slightly over 2.5 wide; nucleus anterior to the middle; no apical radii, but two or three very strong basal radii or plicæ, ending between the large lobes of the basal margin. The circuli are dense, the apical ones distinct and transverse, with no approach whatever to any ctenoid structure. The base of the scale is nearly as in Synodus. (P1. xxxv, fig. 20.)

\section{UMBRIDE. Mud Minnows.}

Umbra limi (Kirtland) from Milwaukee County, Wis. (Grænicher), has peculiar subquadrate or oblong scales, the largest about $3 \mathrm{~mm}$. long, wholly unlike those of Esox. There are no radii, nor is the basal margin at all lobed. The very coarse circuli are essentially longitudinal, extending from one end of the scale to the other, but the innermost slant toward the middle line, meeting those of the opposite side at an extremely acute angle. In the largest scales the apical circuli are not angled in the middle, but normally arched, becoming transverse in the middle; the basal circuli in the same scales converge to two or three points, producing a transversely zigzag appearance. In Kneria the system of circuli is very much the same, though differing in detail. Much more noteworthy and surprising is the great resemblance in structure to the scales of Urophycis regius. So far as the scales go, Umbra and Urophycis might be imagined to belong to closely allied genera. Dr. Gill (Smiths. Misc. Coll., vol. 45, p. 297) has given a rather unsatisfactory figure of an Umbra scale.

\section{P(ECIILID F. Killifishes. (P1. XXXv, fig. 21, 22; pl. XXXVI, fig. 23.)}

Scales broad, more or less semicircular, cycloid, with the nucleus apicad of middle and strong basal radii. No apical radii; circuli not, or not very, dense. Tilapia (Cichlidæ) has the same sort of scale, thus quite different from that of Pomacentridæ (Eupomacentrus and Abudefduf examined), which is ctenoid, of the ordinary Acanthopterygian type.a Compared with Esox or Lucius the Pœciliid scale differs by its broad form (the scale of Lucius is longer than broad), numerous basal radii (two or three in

a Many Cichlidæ have ctenoid scales, and no doubt Tilapia is secondarily, not primitively, cycloid; a parallel development to that of the Embioticidx. In fact, it is not quite correct to say that Tilapia is cycloid, since extremely minute marginal teeth can be detected with the compound microscope. 
Lucius), and much less dense circuli. On the other hand, the scale of Dallia pectoralis does not essentially differ from the smaller pœciliid scales, though the sculpture is less regular. Latinucleate scales are common in the pœciliid material examined.

The following rather unsatisfactory key is based on normal (not latinucleate) scales:

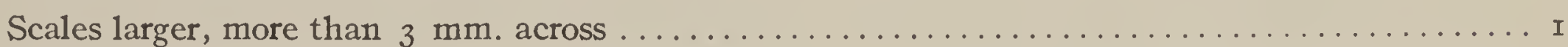

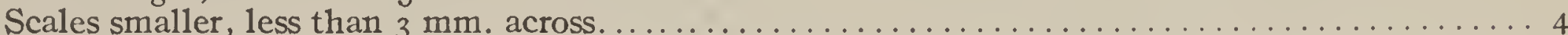

I. Apicolateral outline a regular even curve, or without angles; nucleus a short distance apicad of middle; basal radii about I7, only about the Io midmost complete.

Cyprinodon carpio Günther. Tarpon Springs, Fla. (Evermann \& Kendall).

Apicolateral outline evidently bent or angled, the apical margin thus separated from the lateral.. 2

2. Nucleus less than a third of length of scale from apex; apicolateral angles pronounced, but apical margin convex; basal radii about I3 to I6.

Gambusia puncticulata Poey. San Antonio, Pinar del Rio, Cuba (Eigenmann \& Riddle)

Nucleus more than a third of length of scale from apex ...........................

3. Scale larger, very broad (lat. pr. $6 \mathrm{~mm}$.), apical margin hardly elevated.

Scale smaller, not so broad (lat. pr. $4 \mathrm{~mm}$.) apical margin more elevated.

Mollienisia latipinna Le Sueur, Gordon's Pass, Fla. (Henshall). Differing from the above two in having the scale longer than broad.

Fundulus majalis (Walbaum).

4. Nucleus far above middle of scale; basal radii about Io or II

Pocilia butleri; Jordan; fish about $40 \mathrm{~mm}$. long; Salina Cruz, Mexico (C. C. Deam).

Nucleus about middle of scale or even below. . . . . . . . . . . . . . . . . . . . . .

5. Scale subquadrate, with more or less evident anterolateral angles.

Scale broad, not subquadrate, without anterobasal angles

Fundulus diaphanus (LeSueur), Osterville, Mass.

6. Scale less than $I_{1}^{1} / 2 \mathrm{~mm}$. diameter........ Lucania parva (Baird \& Girard), Woods Hole, Mass. Scale more than $\mathrm{I} / 2 \mathrm{~mm}$. diameter.

Gambusia affinis (Baird \& Girard), Myakka River, Florida (J. A. Henshall).

Dr. Max Ellis has kindly allowed me to examine scales of Anableps anableps (Linnæus) the foureyed fish, and $A$. microlepis Garman, which he collected at Georgetown, British Guiana. They are quite large, those of $A$. anableps much broader than long, with a width of about $8 \mathrm{~mm}$., those of $A$. microlepis smaller, and not so broad. In all respects they are quite typical pœciliid scales, much like those of Cyprinodon, but with considerably denser lateral circuli.

\section{Order XENOMI.}

\section{DALLIIDEE. Alaska blackfish.}

Dallia pectoralis Bean, from Nushagak, Alaska (Albatross collections) has small scales about I $1 / 2 \mathrm{~mm}$. diameter, with coarse circuli and numerous (about I $_{5}$ ) basal radii, the basal margin finely scalloped. There is nothing in these scales which might not be expected in the Pœciliidæ. Regan has recently proposed to include the Esocidæ, Umbridæ, and Dalliidæ in Haplomi and to recognize a new order, Microcyprini, for the Pœciliidæ and Amblyopsidæ. So far as the scales go, the following arrangement would seem natural.

I. Umbridæ.

2. . . . A. Esocidæ.

$$
\text { B. . . . . a. Dalliidæ. }
$$

the last showing a close approach to the acanthopterygian type. 


\section{Order ACANTHOPTERI. Spiny-rayed fishes.}

THE ACANTHOPTERYGIAN TYPE OF SCAIE.

The serranid Centropristes striatus (Linnæus), the black sea bass, from Woods Hole, Mass., may be taken as a type for the definition of the acanthopterygian scale. This scale is more or less quadrate, with the nucleus subapical, the basal circuli fine and transverse, the basal radii strong, spreading out like a fan, and the apical area covered with fine dentiform structures which can be counted in rows obliquely or transversely, and on the margin form a series of fine teeth. The Centropristes scale described is atypical in one respect-the marginal teeth are truncate instead of pointed. The toothed or ctenoid feature appears to be derived from the longitudinal apical circuli which become modified and segmented, the terminal segments especially taking the form of teeth. It is this segmentated arrangement which gives the apical area in acanthopterygians its special character, resembling very much the arrangement of bracts in the heads of some composite flowers. In the pœciliid scale we have a structure resembling much that of the acanthopterygians, but the ctenoid character wholly undeveloped; in some cichlids we attain a superficially similar condition, the ctenoid character having been lost.

At first sight the scales of the various acanthopterygian families Hæmulidæ, Lobotidæ, Serranidæ, Lutianidæ, Percidæ, Centrarchidæ, Anabantidæ, Sciænidæ, Mullidæ, Polynemidæ, and Mugilidæ appear so much alike that classification seems extremely difficult. There are, however, some good distinctions visible on close comparison and brought out more or less in the following table. This does not apply to latinucleate or lateral line scales.

Basal margin broadly emarginate in middle, the basal radii (about 4 or 6 distinct) nearly parallel, converging toward the margin; teeth of apical margin very small, not different from the submarginal structures...................... Mugil curema Cuvier \& Valenciennes (Mugilidæ)

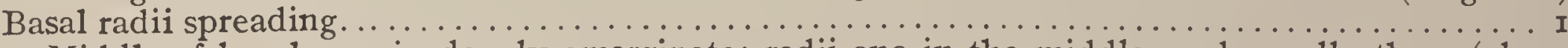

I. Middle of basal margin deeply emarginate; radii one in the middle, and usually three (closer together than the innermost to the middle one) on each side, not deeply impressed; apical modified area reaching nearly to nucleus; apical marginal teeth very small, sharp; subapical pattern composed of elements resembling phalanges, but grooved or bicarinate. $a$ Polydactylus octonemus Girard (Polynemidæ)

Basal margin deeply lobed between the five of six widely and often irregularly spaced basal radii; large scales with extremely fine circuli; modified marginal area not approaching nucleus; marginal teeth sharp; submarginal elements phalangiform, flattened, looking like bricks placed on end, without grooves or keels, though some of the basal ones may have broken ver-

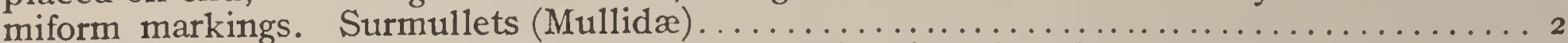

Not like the above (in Perca the basal margin is strongly lobed, but then the basal radii are regular and very deeply impressed, and the apical region is differentiated into two parts) . . . . . 4

2. Subapical marginal elements longer, many about four times as long as broad.

Mullus auratus Jordan \& Gilbert, Woods Hole, Mass.

Subapical marginal elements shorter, none about four times as long as broad............. 3 Elements of apical area in 5 or 6 transverse rows (only two in latinucleate scales).

Elements of apical area in 8 or 9 transverse rows.

Upeneus dentatus Gill. Clarion Island (Albatross)

Mulloides samoensis Günther. Honolulu, Hawaii (Jordan \& Evermann)

4. Apical area beset with linear, spine-like structures (the marginal teeth not differing), the lateral ones often continuous at base with the circuli; apical circuli very widely spaced, meeting at about a right angle above nucleus; basal radii about I5 (Anabantidæ).

Anabas scandens Linnæus. Lake Buhi, Philippine Islands

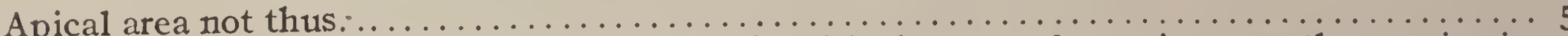

Scales conspicuously longer than broad; margin with about 7 or 8 prominent teeth or projections, to the ends of which the basal framework of the scale is carried; apical area with much reddish brown pigment; scale suggestive of Achirus, but the subapical structure different.

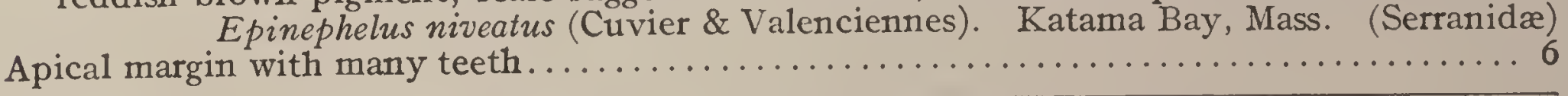

a In Mugil these structures are dentiform, like pointed scales, thus very different. 
6. Marginal teeth truncate, often (except in Micropogon) broader at end than in middle..... 7 Marginal teeth sharply or rather obtusely pointed ....................... I2

7. Circuli above the nucleus broad and sublongitudinal, so that the nucleus and adjacent circuli

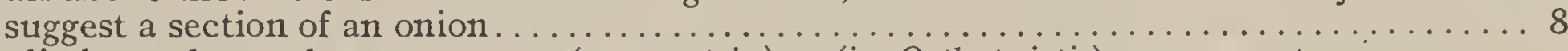

Circuli above the nucleus transverse (concentric) or (in Orthopristis) evanescent.......... ro

8. Scales much larger (about $8 \mathrm{~mm}$. long and broad); elements of apical area with the median oblique rows about $\mathrm{x} 2$ or 13 , but the inner ones poorly developed; basal radii about 9 or 10 . Centropistes striatus (Linnæus). Woods Hole, Mass. (Serranidæ)

Scales smaller (less than $4 \mathrm{~mm}$. long), longer than broad; inner elements of apical area distinct (Serranidæ) .

9. Scales 3 to nearly $4 \mathrm{~mm}$. long.

Paralabrax maculatofasciatus (Steindachner). Guaymas, Mexico (Albatross)

Scales $11 / 2$ to $\mathrm{I}^{2} / 3 \mathrm{~mm}$. long.... Faralabrax clathratus (Girard). San Diego Bay, Cal. (Albatross)

Io. Circuli above the nucleus lost, the surface finely roughened.

Orthopristis chalceus (Günther). Guaymas or Clarion Island (Albatross). (Hæmulidæ)

Circuli above the nucleus distinct.

II. Scale larger, up to over ro mm. broad; elements of apical area in middle about $\mathrm{r} 6$ in a longi-

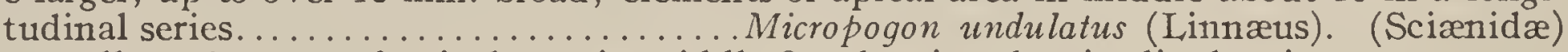
Scale smaller; elements of apical area in middle 8 or less in a longitudinal series.

Leiostomus xanthurus Lacépède. Florida. (Sciænidæ)

I2. Apical teeth very short, for the most part hardly so long as their distance apart......... I3 Apical teeth well developed...................................... I4

13. Apical teeth more or less bifid at tip; sculpture of apical area strong.

Morone americana (Gmelin), fish nearly 8 inches long. (Serranidæ) Apical teeth not bifid; sculpture of apical area weak

Micropterus salmoides (Lacépède). Falmouth, Mass. (Centrarchidæ)

I4. Scales large, colorless, very broad (a well developed one about II mm. broad and 8 long), often inequilateral; basal radii very numerous (about 40) and close together; elements of apical area longitudinally ridged or keeled.

Cynoscion regalis (Bloch \& Schneider). Woods Hole, Mass. (Sciænidæ)

Scales very large, quadrate, equilateral (a well developed one about $16 \mathrm{~mm}$. long and $15^{1 / 2}$ broad), orange-fulvous; basal radii very numerous (about 37 , but many only in the peripheral area); circuli puncticulate; submarginal elements of apical area much longer than broad ........................... Lobotes surinamensis (Bloch). (Lobotidæ)

Scales smaller and otherwise different; many very small.

I5. Base of scale very deeply crenate, many of the lobes as long as broad; basal radii 5 or 6 ; apical area with a marginal band in which the elements are very distinct, but mesad of this they are indistinct, the transition abrupt.

Perca flavescens (Mitchill). Falmouth, Mass. (Percidæ)

Base of scale not thus deeply crenate..... I6

16. Scales larger, fully $5 \mathrm{~mm}$. long and broad; basal radii very numerous (about $28-32$ ) and close together; basal circuli puncticulate.

Roccus lineatus (Bloch). Woods Hole, Mass. (Serranidæ)

Scale much smaller; basal radii less than $20 \ldots \ldots \ldots \ldots \ldots \ldots \ldots \ldots \ldots \ldots \ldots \ldots \ldots \ldots \ldots$

I7. Basal radii about 18 .

Hypohomus spilotus (Gilbert). Hector Creek, Kentucky. (Woolman). (Percidæ)

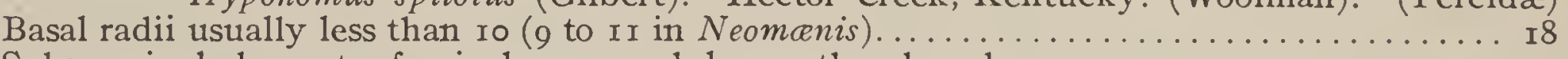

I8. Submarginal elements of apical area much longer than broad $\ldots \ldots \ldots \ldots \ldots \ldots \ldots \ldots \ldots \ldots \ldots$

Submarginal elements of apical area mostly or all broader than long ............... 20

19. Lateral circuli strongly curving inward above.

Morone americana (Gmelin), fish 3 inches long. (Serranidæ)

Lateral circuli (except the innermost) hardly curving inward above.

Neomenis analis (Cuvier \& Valenciennes). Katama Bay, Mass. (Lutianidæ)

20. Scales very small; apical teeth broad at base, rapidly tapering to very slender sharp points; basal radii 6 to $9 . . . \ldots$. Boleosoma nigrum (Rafinesque). Osterville, Mass. (Percidæ) Apical teeth conical, more regularly tapering.

2I. Lateral circuli (except the innermost) directed obliquely outward above, so that if they were continued in a straight line below until they met, they would form a broad V; basal radii

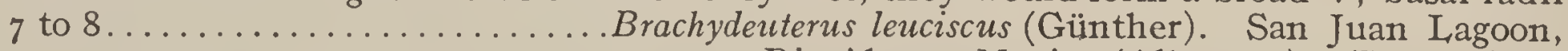
Rio Ahoma, Mexico (Albatross). (Hæmulidæ)

Lateral circuli (except the innermost) directed upward above ...................22 22. Submarginal elements of apical area appearing distinctly concave below (helmet-shaped); basal radii 8 Hæmulon steindachneri (Jordan \& Gilbert). Gulf of California (Albatross). (Hæmulidæ) 
Submarginal elements of apical area not appearing concave below................ 23

23. Submarginal elements of apical area hat-shaped.

Cottogaster shumardi (Girard). Wabash River, Ind. (B. W. Evermann). (Percidæ) Submarginal elements of apical area quadrate.

Menticirrhus saxatilis (Bloch \& Schneider). Woods Hole, Mass. (Sciænidæ)

\section{Suborder SynEnTOGnath.}

BELONIDE. Marine gars.

The houndfish, Tylosurus acus (Lacépède) has irregular elongate (broad) scales with conspicuous concentric circuli, but no radii whatever. They thus recall the scales of Salmonidæ.

EXOCETIDE. Fly ing-fishes.

Cypsilurus heterurus (Rafinesque) has large broad thin scales, about to $\mathrm{mm}$. broad and 8 long; nucleus a short distance below middle; circuli strong, concentric, in some scales much more widely spaced laterally, and then often angled; margin wholly cycloid; about 4 or 5 strong basal radii (more in latinucleate scales), none apical. Except for the presence of radii, this is very similar to Tylosurus. It seems also to lead toward the scombrid type.

\section{HEMIRHAMPHIDE. Halfbeaks.}

Hyporhamphus unifasciatus (Ranzani), from Woods Hole, Mass., has very broad scales, about $5 \mathrm{~mm}$. long and 8, or slightly over, broad; apical margin broadly rounded; laterobasal corners rounded but evident; middle of base with a broad median lobe, which may be bilobed; basal radii two or three, widely diverging; nucleus near middle, but indistinct; apical field entirely covered with very fine transverse circuli, except a slender sculptureless submarginal band; basal field with transverse more widely spaced circuli, bending upwards and still more widely spaced in the lateral fields, and ultimately, when not reaching the margin, forming acute angles with the adjacent circuli of the apical field. The transverse dense apical circuli remind one of Xystcma (Gerridæ), but in Xystcma there is no sign of lateral angulation, and the apical marginal region is entirely different.

The scale of Hyporhamphus is evidently a further development, much more extreme, of the type of Cypsilurus. It also seems to point clearly in the direction of the scombrids.

\section{SCOMBRESOCIDE. Sauries.}

The billfish, Scombresox saurus (Walbaum) represents a still more extreme development along the lines of Hyporhamphus. The thin scale is about $5 \mathrm{~mm}$. long and 8 broad, without angles or radii. The circuli are everywhere completely transverse, denser on the apical than the basal half, the two halves separated in some cases by more or less of an interval about the middle. At each extreme side is a thin zone, sculptureless except for a few irregular lines. The scales are of the same general type as those of the Scombridæ and Cheilodipteridæ.

So far as seen, the synentognathous families may be separated thus:

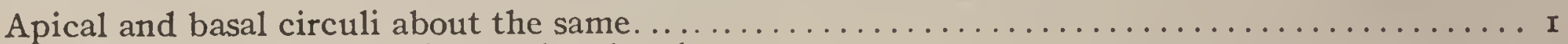

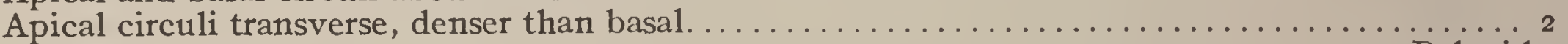

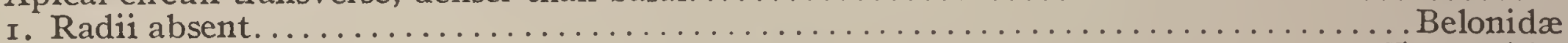

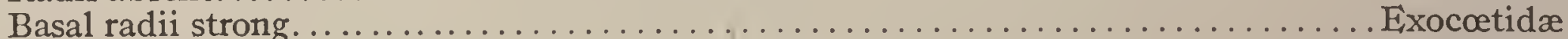

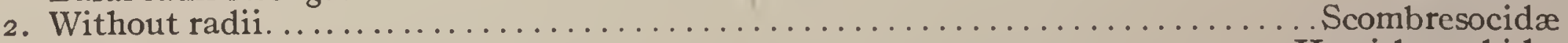

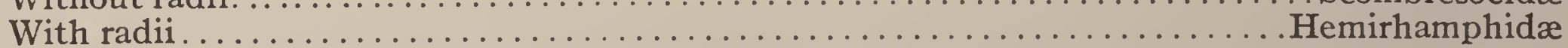

If doubt should arise owing to the apical circuli of Scombresocidæ not being much denser than the basal, the family will still be easily recognized by the completely transverse character of the circuli, so that the effect of lateral angulation is lost. Dr. Jordan states that Regan (I9I I) recognizes an order Synentognathi, with one suborder for the belonids and scombresocids, and another for the hemirhamphids and exocotids. The scale characters would not have suggested this arrangement.

$89970^{\circ}-\mathrm{I} 3-3$ 
6. Marginal teeth truncate, often (except in Micropogon) broader at end than in middle..... 7

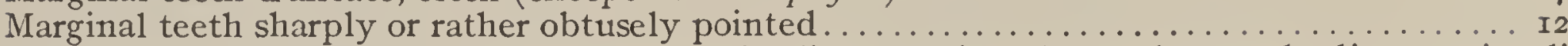

7. Circuli above the nucleus broad and sublongitudinal, so that the nucleus and adjacent circuli

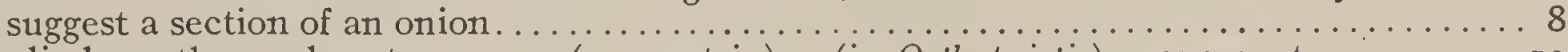

Circuli above the nucleus transverse (concentric) or (in Orthopristis) evanescent.......... Io

8. Scales much larger (about $8 \mathrm{~mm}$. long and broad); elements of apical area with the median oblique rows about $\mathrm{I} 2$ or $\mathrm{I} 3$, but the inner ones poorly developed; basal radii about 9 or ro.

Centropistes striatus (Linnæus). Woods Hole, Mass. (Serranidæ)

Scales smaller (less than $4 \mathrm{~mm}$. long), longer than broad; inner elements of apical area distinct

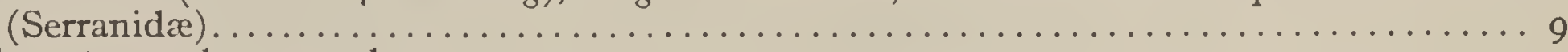

9. Scales 3 to nearly $4 \mathrm{~mm}$. long.

Paralabrax maculatofasciatus (Steindachner). Guaymas, Mexico (Albatross)

Scales $I^{I} / 2$ to $I^{2} / 3 \mathrm{~mm}$. long.... Faralabrax clathratus (Girard). San Diego Bay, Cal. (Albatross)

ro. Circuli above the nucleus lost, the surface finely roughened.

Orthopristis chalceus (Günther). Guaymas or Clarion Island (Albatross). (Hæmulidæ)

Circuli above the nucleus distinct. . . . . . . . . . . . . . . . . . . . . . . . .

Ir. Scale larger, up to over Io $\mathrm{mm}$. broad; elements of apical area in middle about I6 in a longi-

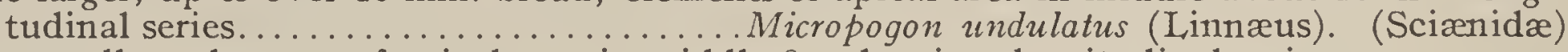
Scale smaller; elements of apical area in middle 8 or less in a longitudinal series.

Leiostomus xanthurus Lacépède. Florida. (Sciænidæ)

12. Apical teeth very short, for the most part hardly so long as their distance apart.......... I3

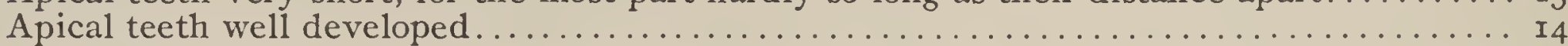

I3. Apical teeth more or less bifid at tip; sculpture of apical area strong.

Apical teeth not bifid; sculpture of apical area weak.

Morone americana (Gmelin), fish nearly 8 inches long. (Serranidæ) Micropterus salmoides (Lacépède). Falmouth, Mass. (Centrarchidæ)

14. Scales large, colorless, very broad (a well developed one about I I mm. broad and 8 long), often inequilateral; basal radii very numerous (about 40) and close together; elements of apical area longitudinally ridged or keeled.

Cynoscion regalis (Bloch \& Schneider). Woods Hole, Mass. (Sciænidæ)

Scales very large, quadrate, equilateral (a well developed one about $16 \mathrm{~mm}$. long and $15^{1 / 2}$ broad), orange-fulvous; basal radii very numerous (about 37 , but many only in the peripheral area); circuli puncticulate; submarginal elements of apical area much longer

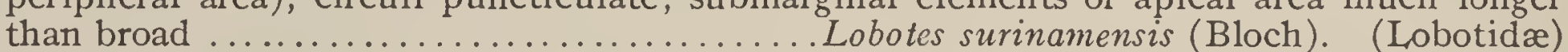

Scales smaller and otherwise different; many very small .................... I5

I5. Base of scale very deeply crenate, many of the lobes as long as broad; basal radii 5 or 6; apical area with a marginal band in which the elements are very distinct, but mesad of this they are indistinct, the transition abrupt.

Base of scale not thus deeply crenate. Perca flavescens (Mitchill). Falmouth, Mass. (Percidæ)

16. Scales larger, fully $5 \mathrm{~mm}$. long and broad; basal radii very numerous (about 28.32 ) and close together; basal circuli puncticulate.

Roccus lineatus (Bloch). Woods Hole, Mass. (Serranidæ)

Scale much smaller; basal radii less than $20 \ldots \ldots \ldots \ldots \ldots \ldots \ldots \ldots \ldots \ldots \ldots \ldots \ldots$

I7. Basal radii about 18 .

Hypohomus spilotus (Gilbert). Hector Creek, Kentucky. (Woolman). (Percidæ)

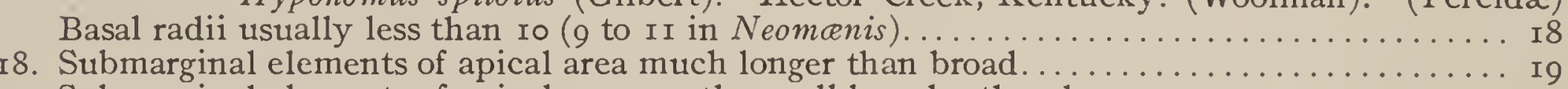

Submarginal elements of apical area mostly or all broader than long ............... 20

I9. Lateral circuli strongly curving inward above.

Morone americana (Gmelin), fish 3 inches long. (Serranidæ)

Lateral circuli (except the innermost) hardly curving inward above.

Neomanis analis (Cuvier \& Valenciennes). Katama Bay, Mass. (Lutianidæ)

20. Scales very small; apical teeth broad at base, rapidly tapering to very slender sharp points; basal radii 6 to $9 . . . . .$. . Boleosoma nigrum (Rafinesque). Osterville, Mass. (Percidæ)

Apical teeth conical, more regularly tapering .................

2I. Lateral circuli (except the innermost) directed obliquely outward above, so that if they were continued in a straight line below until they met, they would form a broad V; basal radii

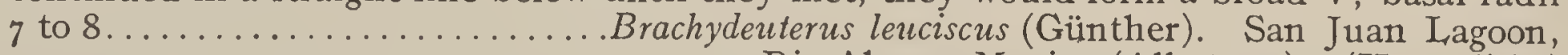
Rio Ahoma, Mexico (Albatross). (Hæmulidæ)

Lateral circuli (except the innermost) directed upward above.................. 22. Submarginal elements of apical area appearing distinctly concave below (helmet-shaped); basal radii 8 Hæmulon steindachneri (Jordan \& Gilbert). Gulf of California (Albatross). (Hæmulidæ) 
Submarginal elements of apical area not appearing concave below............... 23

23. Submarginal elements of apical area hat-shaped.

Cottogaster shumardi (Girard). Wabash River, Ind. (B. W. Evermann). (Percidæ) Submarginal elements of apical area quadrate.

Menticirrhus saxatilis (Bloch \& Schneider). Woods Hole, Mass. (Sciænidæ)

\section{Suborder SynENTOGNATH.}

\section{BELONIDE. Marine gars.}

The houndfish, Tylosurus acus (Lacépède) has irregular elongate (broad) scales with conspicuous concentric circuli, but no radii whatever. They thus recall the scales of Salmonidx.

\section{EXOCETIDE. Flying-fishes.}

Cypsilurus heterurus (Rafinesque) has large broad thin scales, about Io $\mathrm{mm}$. broad and 8 long; nucleus a short distance below middle; circuli strong, concentric, in some scales much more widely spaced laterally, and then often angled; margin wholly cycloid; about 4 or 5 strong basal radii (more in latinucleate scales), none apical. Except for the presence of radii, this is very similar to Tylosurus. It seems also to lead toward the scombrid type.

\section{HEMIRHAMPHID E. Halfbeaks.}

Hyporhamphus unifasciatus (Ranzani), from Woods Hole, Mass., has very broad scales, about $5 \mathrm{~mm}$. long and 8, or slightly over, broad; apical margin broadly rounded; laterobasal corners rounded but evident; middle of base with a broad median lobe, which may be bilobed; basal radii two or three, widely diverging; nucleus near middle, but indistinct; apical field entirely covered with very fine transverse circuli, except a slender sculptureless submarginal band; basal field with transverse more widely spaced circuli, bending upwards and still more widely spaced in the lateral fields, and ultimately, when not reaching the margin, forming acute angles with the adjacent circuli of the apical field. The transverse dense apical circuli remind one of Xystcma (Gerridæ), but in Xystama there is no sign of lateral angulation, and the apical marginal region is entirely different.

The scale of Hyporhamphus is evidently a further development, much more extreme, of the type of Cypsilurus. It also seems to point clearly in the direction of the scombrids.

\section{SCOMBRESOCIDA. Sauries.}

The billfish, Scombresox saurus (Walbaum) represents a still more extreme development along the lines of Hyporhamphus. The thin scale is about $5 \mathrm{~mm}$. long and $8 \mathrm{broad}$, without angles or radii. The circuli are everywhere completely transverse, denser on the apical than the basal half, the two halves separated in some cases by more or less of an interval about the middle. At each extreme side is a thin zone, sculptureless except for a few irregular lines. The scales are of the same general type as those of the Scombridæ and Cheilodipteridæ.

So far as seen, the synentognathous families may be separated thus:

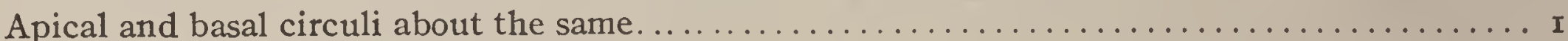

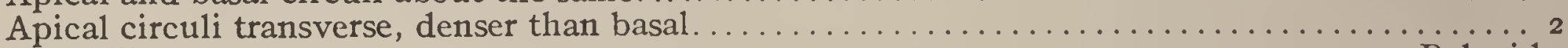

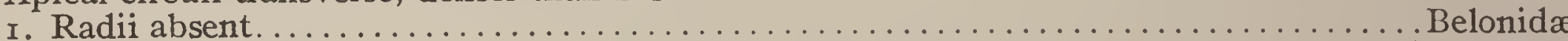

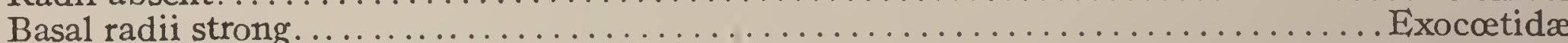

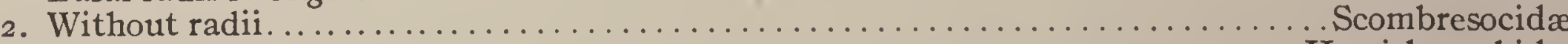

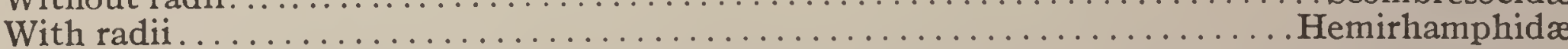

If doubt should arise owing to the apical circuli of Scombresocidæ not being much denser than the basal, the family will still be easily recognized by the completely transverse character of the circuli, so that the effect of lateral angulation is lost. Dr. Jordan states that Regan (IgII) recognizes an order Synentognathi, with one suborder for the belonids and scombresocids, and another for the hemirhamphids and exocœtids. The scale characters would not have suggested this arrangement.

$89970^{\circ}-\mathrm{I} 3-3$ 
Suborder PERCESOCES.

ATHERINIDE. Silversides. (P1. XXXVI, fig. 25.)

For a general account of the scales of this family, see Proceedings of the Biological Society of Washington, volume xxiII, pages 47-48. The genera Kirtlandia and Menidia are discussed, and the resemblance to the scombrids is noted. All the scales except Kirtlandia have distinct basal radii, with the lower margin usually scalloped; the laterobasal angles are distinct, and there are distinct apical radii in some forms, as Chirostoma. The following key separates the species before me:

Lateral and apical circuli alike and continuous, the circuli very widely spaced; scale very small, less than I $\mathrm{T} / 2 \mathrm{~mm}$. broad, strictly cycloid; no apical radii; basal radii well developed, about 5 or 6; laterobasal angles rectangular.

Atherinops regis Jenkins \& Evermann. (Algodones Lagoon, Mexico; Albatross)

Lateral circuli strongly differentiated from apical, or the latter modified or partly suppressed... I

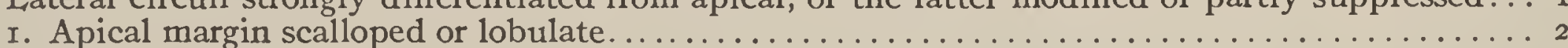

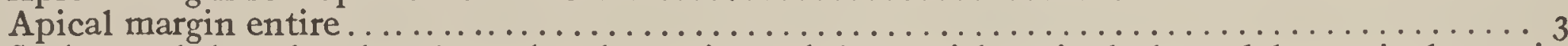

2. Scale much broader than long; basal margin undulate, with a single large lobe; apical margin irregularly lobed, with traces of radii; basal radii reduced to one or two broad folds, no true radii; apical field without sculpture, but across the middle of the scale, apicad of the regular circuli, is an area of very fine longitudinal lines, in the middle on the apical side breaking into very fine labyrinthiform markings.......Kirtlandia laciniata (Swain). (Chesapeake Bay, Va.)

Scale little (sometimes not at all) broader than long; basal margin more or less angulate in the middle; apical margin finely irregularly scalloped, with evident though slender radii; basal radii about 7 to Io, well developed; lateral circuli very widely spaced, but apical field with extremely fine transverse circuli, which are much broken, and in the nuclear area mostly reduced to dots. . Chirostoma crystallinum Jordan \& Snyder. (Lake Chapala, Mexico; J.N. Rose)

3. Basal radii distinct; lateral circuli very widely spaced; apical circuli transverse, very dense, more or less broken, toward the nucleus reduced to granules; apical radii very slender, irregular, not always evident.

Menidia peninsula (Goode \& Bean); M. menidia (Linnæus); $M$. notata (Mitchill)

Of this series, Chirostoma is possibly the most primitive, but Atherinops stands apart and has the primitive character of continuous, uniform circuli in the lateral and apical regions. Kirtlandia seems much modified, but hardly from a Menidia-like basis. Probably Atherinops and its allies should form a distinct subfamily.

The scales of Menidia notata described in my paper cited above were not adult; other scales from the Bureau of Fisheries collection are about $3.5 \mathrm{~mm}$. broad, with the apical margin subangulate or roof-like in profile.

\section{MUGILIDE. Mullets.}

The white mullet, Mugil curcma Cuvier \& Valenciennes, from the collection at Woods Hole, has large rounded scales, with a straight, medially emarginate base; length about $9 \cdot 5-10 \mathrm{~mm}$; breadth II-II.5; basal radii few, crowded about the middle of the scale; nucleus apicad of middle; lateral circuli coarser than basal; apical margin minutely ctenoid, the apical region with the minutely imbricated structure of typical ctenoid scales.

Here, then, we first meet with the typically ctenoid type of scale, as developed among the Acanthopterygians. The ctenoid scales of certain Characinidæ are of an entirely different character.

There is no evident connection between the scales of Mugil and those of the Atherinidæ.

\section{SPHYRENIDEE. Barracudas.}

The scales of Sphyrcna are very peculiar, and wholly unlike those of the Atherinidæ or Mullidæ. S. picuda Bloch \& Schneider, from Tampa, Florida, has relatively large reddish scales, about $7 \mathrm{~mm}$. long and a little over 6 broad, the lateral and basal margins gently convex, laterobasal corners obtuse, the apical region thin and without sculpture. The sculptured part of the scale has throughout extremely dense circuli, which, except in the upper lateral region, are interrupted by very numerous radii. The radii are very uniform, about 5 to 9 to a millimeter of the margin. The midmost circuli are not only divided into short sections by the radii, but the sections themselves are cut at intervals by very fine 
lines, so as to seem segmented. In S. borealis DeKay, from Woods Hole, the colorless scales have a diameter of hardly $\mathrm{x} / 2 \mathrm{~mm}$., and the fine radii, instead of continuously interrupting the circuli, are represented by series of minute round holes, which, however, coalesce in some places, producing a condition like that of the great barracuda, S. picuda. In the northern barracuda, $S$. borealis, the apical sculptureless area is very small or wanting. The sphyrænid scale is very suggestive of that of Gadus and allied genera.

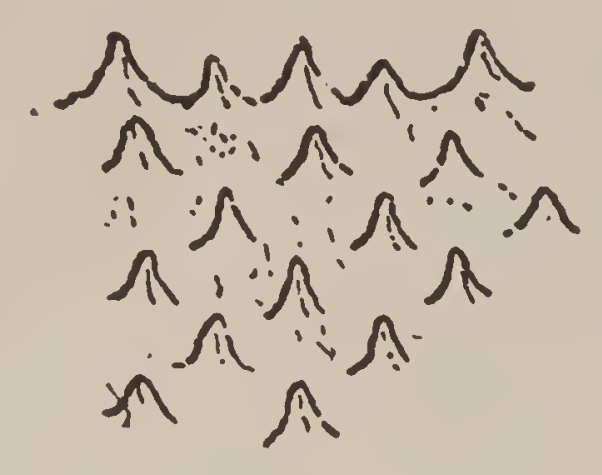

FiG. 9.-Mugil (Mugilidæ). Ctenoid area. Bureau of Fisheries.

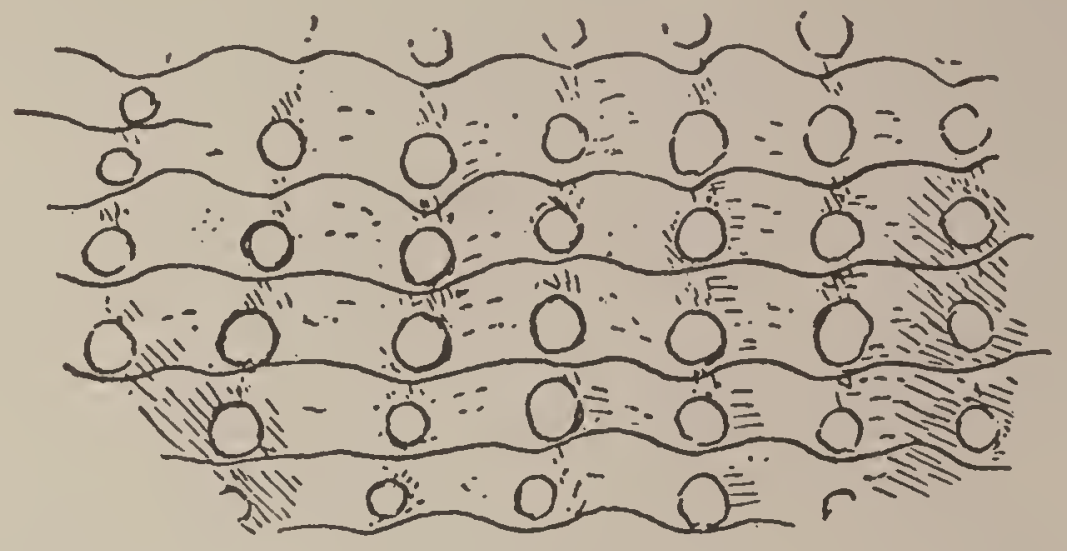

FIG. I0.-Sphyræna borealis (Sphyrænidæ). Sculpture. Bureau of Fisheries. The transverse strands are circuli.

Jordan \& Evermann state that the families Atherinidæ, Mugilidæ, and Sphyrænidæ are closely related (Bulletin 47, U. S. National Museum, pt. I, p. 788). They were associated together in the order Percesoces by Cope. Boulenger includes in Percesoces several other families, as Anabantidæ, Stromateidæ, Polynemidæ, Scombresocidæ, etc., stating that the group is perhaps only an artificial one, but "a gradual passage may be traced connecting the most aberrant types."

The scales would certainly suggest that the three families described above are not very closely related.

\section{Suborder RHEGNOPTERI.}

\section{POLYNEMIDA. Threadfins.}

Jordan states that the Polynemidx are allied to the Mugilidæ, but differ from them and from all other fishes in the structure of the pectoral fin and its basal bones. In Boulenger's arrangement they go in the Percesoces, following the Mugilidx. In Polydactylus octonemus Girard the scale is quite

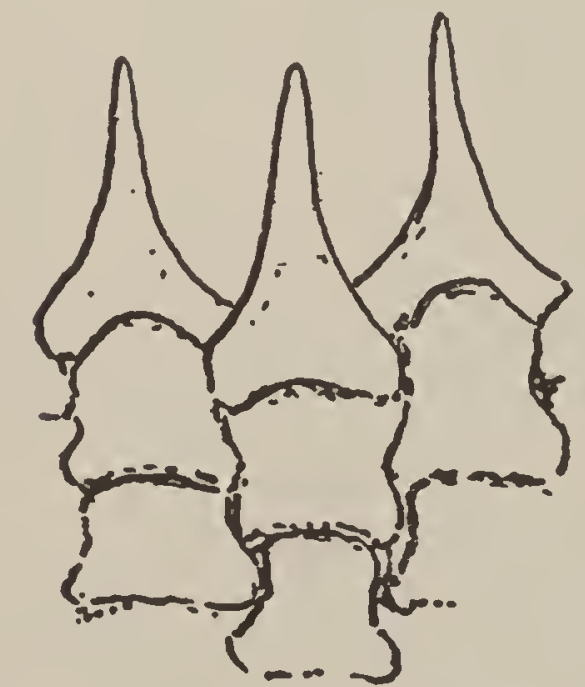

Fig. 1x.-Polydactylus (Polynemidæ). Apical teeth. Bureau of Fisheries.

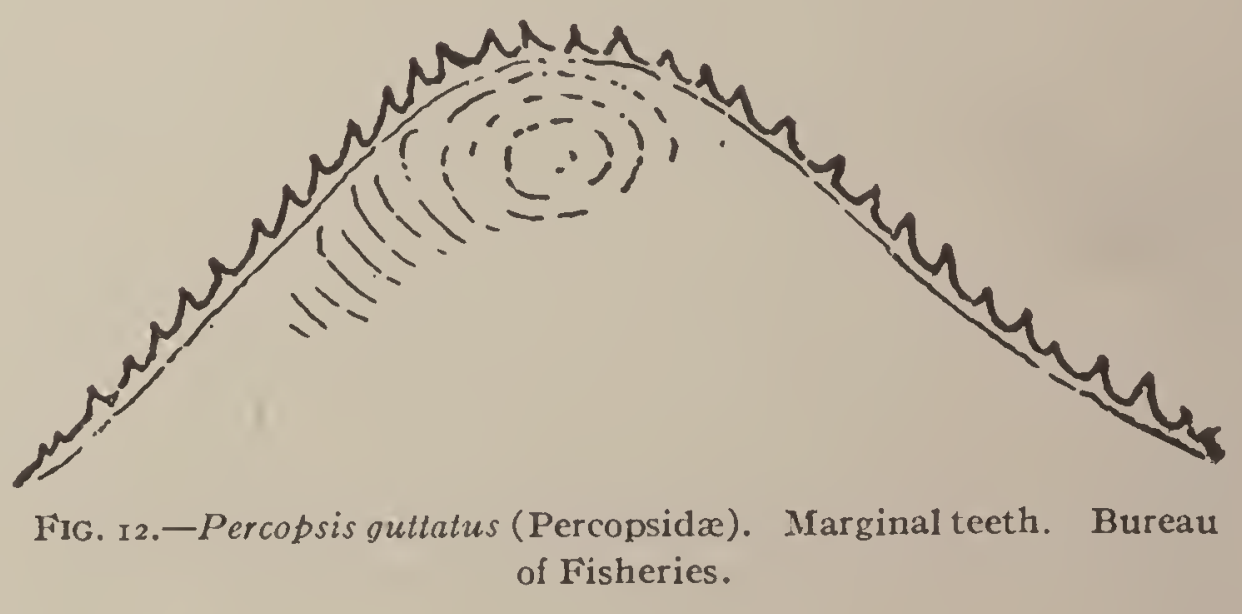

typically Acanthopterygian, with ctenoid apical area, nucleus apicad of middle, and well-developed basal radii. The scale is nearly as in Mugil, having the same basal emargination, but differing in the spreading basal radii. The minute elements of the apical area are not as in Mugil, the submarginal ones being truncate instead of pointed.

Although there are differences, the scales would suggest that the Polynemidæ are actually nearer to the Mugilidæ than the latter to the Atherinidæ or especially the Sphyrænidæ. 


\section{Suborder SALMOPERC瓜. Trout perch.}

\section{PERCOPSIDE. Sand rollers.}

The trout perch, Percopsis guttatus Agassiz, from East Okoboji Lake, Iowa (Evermann), has broad subtriangulate scales, with the apical margin forming two sides of the triangle, each side with about I 7 sharp teeth. Nucleus very close to apex; circuli widely spaced; a slight tendency to basal plication, but no distinct radii. In the form of the apical region, with the nucleus very far apicad and the single row of sharp teeth, this reminds one of Gobius and its allies. In the Gobiidæ, however, the basal radii are very well formed and numerous.

\section{Suborder BerycoIDEA. Berycoid fishes.}

\section{BERYCIDE. Alfonsinos.}

Jordan \& Fowler say of this family: "Covered with ctenoid, or cycloid, foliate, or granular scales." I have from the United States National Museum scales of Beryx splendens Lowe (fish 2 I inches long) from Japan. They are about $8 \mathrm{~mm}$. long and 9.5-10.5 mm. broad, with the exposed part colorless and the covered pale yellowish red. The apical margin is thin and rather irregular, wholly without teeth; lateral margins concave; laterobasal corners very prominent; lower margin convex, irregularly subcrenulate; nucleus a short distance apicad of middle; basal circuli dense; weak basal folds in place of radii; broad apical region with growth lines but no circuli, and with scattered small round perforations. These perforations in the apical region sometimes have elevated margins, and in the region of the nucleus their place is taken by small sharp spines. Probably they arise as spines in every case, and the spines breaking off leave perforations. Jordan \& Fowler state that the scales of Beryx splendens "are furnished with fine prickles, giving a somewhat rough touch." In Beryx lineatus, as figured by Sauvage, the prickles or spines of the apical region are large and dense. In either case, the arrangement parallels that found in species of Macrurus, and it is interesting in this connection to note that Regan some years ago suggested that the Gadoids might have come from the same stock which also gave rise to the Berycidæ. In Caulolepis subulidens Garman, as figured by Garman (Memoirs Museum Comparative Zoology, XXIV, I899), the scales are extremely modified, but still have some of the spines or teeth.

TRACHICHYIDE. Deep-sea berycoids.

Garman, in the work just cited, figures the scale of Trachichthys mento Garman. It is transversely oval, without the laterobasal corners of Beryx, but it has a number of true berycoid spines in the subapical region. Boulenger refers the genus to Berycidæ.

\section{HOLOCENTRIDE. Squirrel-fishes. (P1. XXXVI, fig. 26.)}

The scales of the Holocentridæ resemble in shape those of the Berycidæ, being broad, with prominent laterobasal angles. In every case, so far as known to me, the apical margin is armed with strong, straight, comb-like teeth. In some (especially Myripristis murdjan) the subapical region has spiniferous pits, of the same character as the spine-bearing holes of Beryx. The basal margin is straight or nearly so, except that in the middle it is thrown into one or more folds or lobes, indicative of the rudiments of a basal radial system. The scales are all broader than long, but those of Flammeo are not so conspicuously so as those of Holocentrus, and especially Myripristis murdjan; the last are larger than any of the others, about $8 \mathrm{I} / 2 \mathrm{~mm}$. long and $\mathrm{I} 4 \mathrm{~T} / 2$ broad, strongly reddish. The basal circuli in all are excessively fine, more so than in Beryx splendens. The species examined are as follows:

Myripristis murdjan (Forskål). Strongs I., Carolines (M. C. Z.).

Flammeo scythrops. Hawaii.

Flammeo sammara (Forskå1). Hawaii.

Holocentrus diadema Lacépède. Hawaii.

Holocentrus laticeps Cuvier \& Valenciennes. Kaui, Hawaii (M. C. Z.). 
Holocentrus xantherythrus Jordan \& Evermann. Hawaii.

Holocentrus microstoma Günther. Samoa.

The species of Holocentrus are so uniform in their characters that I can not construct a satisfactory key. There are, however, minor differences; e. g., the apical teeth of $H$. xantherythrus are much coarser than those of $H$. laticeps, and the basal radial folds are more prominent in $H$. diadema and laticeps than in the others.

Finding that $H$. laticeps was not recorded from the Hawaiian Islands, I asked Dr. Garman to look at the specimens (M. C. Z., 3440). This he kindly did, and reports that the identification is correct.

Sauvage, in his work on the fishes of Madagascar, has figured scales of Myripristis seychellensis, M. pralinus, M. borbonicus, Holocentrus (or Holocentrum) spiniferus, H. diadema, $H$. leo and Holotrachys lima. These show various peculiarities, but ail confirm the essential uniformity of the holocentrid type, and indicate its general affinity with that of the Berycidæ.

There is an evident resemblance between the holocentrid scale and that of Aphredoderus.

\section{POLYMIXIIDA. Barbudos.}

From the United States National Museum I have scales of Polymixia japonica Steindachner, from Japan (fish $71 / 4$ inches long). They are very broad, with the same general shape and apical spines as Holocentrus, but the basal circuli are very much less dense, and the basal radial folds are very well marked, throwing the basal margin into numerous strong undulations. The laterobasal corners are less prominent than in the holocentrids, and the subapical region is without spines. Thus the Berycoidea, as regards their scales, form a sufficiently compact group, quite isolated from the groups standing on either side of it in the system.

\section{Suborder PERCOMORPHI. Perciform fishes.}

\section{Superfamily SCOMBROIDEA. Mackerel-like fishes.}

Broadly speaking, the families Scombridæ, Carangidæ, Cheilodipteridæ, Stromateidæ, Hemirhamphidæ, Scombresocidæ, Belonidæ, and Exocœtidæ may be ranged together (and apart from the percoid series) on their scales. Atherinidæ show some resemblances also. The fishes are of course variously diverse in other characters.

\section{SCOMBRIDE. Mackerels.}

I have figured the scales of Scomber in Smithsonian Miscellaneous Collections, volume 56, no. I. They are small and thin, broader than long, with the circuli transverse. In the common mackerel, Scomber scombrus (Linnæus), from Woods Hole, the apical margin is more or less, but very irregularly, dentate, without the formation of definite structures like those on genuinely ctenoid scales. At these teeth the circuli are bent upward and angled, and this irregular waviness and angulation is seen here and there in the subapical field, indicating no doubt the teeth of an earlier stage. The fusiform area representing the nucleus is below the middle of the scale, and on each side of it the circuli are acutely angled. The circuli above the nucleus are somewhat denser than those below. The angulation of the lateral circuli in $S$. scombrus is like that of the basal ones in Macrurus.

In the bonito, Sarda sarda (Bloch), and the frigate mackerel, Auxis thazard (Lacépède), the scales are of the same general type, but still smaller and more degenerate, often practically without sculpture. Those of Auxis are often pointed laterally.

\section{CARANGIDE. Cavallas, etc. (P1. XXXVI, fig. 27.)}

The jack, Caranx hippos (Linnæus), has circular scales about $21 / 2 \mathrm{~mm}$. diameter, with central nucleus and fine concentric circuli, not unlike some salmonid. There are no radii or marginal teeth. The inner circuli are variously angled laterally, and in the young the scales are transversely oval, and look just like those of Scomber. The carangid and scombrid scales are therefore very closely allied, although when adult appearing different. 


\section{CHEILODIPTERIDE. Bluefishes.}

The bluefish, Cheilodipterus saltatrix (Linnæus), from Onset, Mass., has scales slightly over $2 \mathrm{~mm}$. long and about 3 broad; apex broadly rounded, base flattened, slightly and obtusely angled in the middle; laterobasal corners rounded but evident; no radii; circuli transverse apically and basally, more or less angulate laterally; nucleus below the middle. The lateral circuli are often angulate only on one side. The apical margin is thin, and when not worn off is irregularly dentate; the coarse circuli are not deflected or angled below these teeth, as they are in Scomber. This scale is entirely of the scombrid type.

\section{STROMATEIDAE. Butterfishes.}

Gobiomorus gronovii (Gmelin), the Portuguese man-of-war fish, has feeble cycloid scales with widely spaced circuli which are more or less wavy. There are no radii. My material is perhaps immature. In the butterfish, Poronotus triacanthus (Peck), from Woods Hole, the scales are as in Cheilodipterus except that there are no signs of apical teeth, while the base often has one or two broad radial folds. The lateral circuli are angulate in most scales.

The pilot-fish, Palinurichthys perciformis (Mitchill), has quadrate scales about $4 \frac{1}{2} \mathrm{~mm}$. long and broad; laterobasal corners distinct; nucleus below the middle; circuli very distinct, the basal denser than the apical, the lateral vertical, parallel with the margin; four or five indistinct basal circuli. This scale is like that of the lake herrings, Leucichthys, and does not at all suggest that of the Scombridæ and allies. Jordan \& Evermann separated the Centrolophidæ (Centrolophus and Palinurichthys) from Stromateidæ, but Jordan has more recently made Stromateidæ include both Centrolophidæ and Nomeidæ (Gobiomorus). The scales would strongly suggest that Centrolophidæ, at least, are a valid family. There is a striking general resemblance between the scale of Palinurichthys and that of Chirostoma crystallinum Jordan \& Snyder (Atherinidæ), but the apical region of the Chirostoma scale is quite different.

PEMPHERIDE. Deep-water Catalufas.

Pempheris otaitensis (species perhaps wrongly determined) from the Red Sea (M. C. Z.), has scales which differ greatly in size on the same fish. The larger ones are about $4 \mathrm{~mm}$. long and 6 broad; strictly cycloid, with circuli all around, transverse in the apical region; no apical radii; nucleus basad of middle; laterobasal comers rounded; about I $_{5}$ strong basal radii, arranged fan-like, the basal margin strongly crenate. This scale, while very different from that of Palinurichthys, shows enough resemblance to suggest affinity.

\section{Superfamily PERCOIDEA.}

\section{CENTRARCHIDE. Sunfishes and basses.}

Mr. B. A. Bean very kindly sent me from the United States National Museum a very full set of centrarchid scales, with numbers only, so that I might classify them without any bias derived from a knowledge of their generic and specific identity. This I did, and afterwards the names and localities were supplied. The result was that I found the group to be on the whole a very compact one, the principal differences being found in the development of the apical teeth (the ctenoid feature), the density of the apical circuli, and the number of basal radii. The scales are quadrate or subquadrate in form, sometimes (Micropterus dolomieu) longer than broad, others (as Lepomis gibbosus) broader than long. No doubt the forms with well developed apical teeth are the most primitive (at least as regards their scales), the centrarchid type being originally ctenoid. It is interesting to note that Archoplites interruptus from San Francisco, the only fresh-water percoid west of the Rocky Mountains, has very strongly ctenoid scales, and the basal radii with an extremely minute beading. It is remarkable that in other forms the ctenoid margin is lost as the scale matures, thus:

(I) Ambloplites rupestris, rock bass; young from Sodus Bay, N. Y., show a ctenoid V-shaped apical area, the apical margin with many sharp teeth; adults from Manchester, Va., show a perfectly entire apical margin, though (except in latinucleate scales) the $V$-shaped ctenoid patch is still visible as a sort of latticework pattern, failing below the margin. This is very different from the broad ctenoid area of Archoplites, the lower margin of which, in well-developed scales, is nearly straight. 
(2) Micropterus salmoides, large-mouth black bass; young from Sodus Bay, N. Y., show in most (but not all) scales a $V$-shaped ctenoid area, with teeth projecting slightly beyond the margin; scales of about the same age, from Falmouth, Mass., show the same, but are considerably narrower; adults from Bemus Point, N. Y., show a very broad ctenoid area, but the margin is toothless, or with extremely short and feeble projections. $M$. dolomieu is without ctenoid features at any age, though the apical circuli sometimes become sharply zigzag.

Scales of Enneacanthus gloriosus, from Washington, D. C., are strongly ctenoid, the ctenoid area very broad and the marginal teeth distinct; they differ conspicuously from those of Archoplites by their broader form, more minute apical teeth, and more numerous (usually I $2_{2}$ or $\mathrm{I}_{3}$ ) basal radii.

Chonobryttus gulosus, warmouth, from Washington, D. C., has variably ctenoid scales, the ctenoid area sometimes reduced to a very small patch. A hybrid between C. gulosus and Lepomis gibbosus, from the District of Columbia, has the ctenoid feature well developed, the area broad.

I could find nothing in the scales to justify the division of Lepomis into Apomotis, Lepomis, and Eupomotis. In the classification made without knowledge of the names, nearly all the species with intermediate characters-poorly developed but visible ctenoid features-fall in Lepomis, which is thus fairly compact on scale characters; but the so-called genera segregated from Lepomis are inextricably mixed. In the blue-gills Lepomis pallidus and holbrookii the apical margin is entire in some specimens, herein agreeing with the normal condition of Pomoxis. A disturbing feature is the great variability of some of the species, not only individual but racial. I give some examples:

(I) Micropterus salmoides (Lacepédè), large-mouth black bass. Scales from Falmouth, Mass., narrower than those from Sodus Bay, N. Y.

(2) Lepomis gibbosus (Linnæus), pumpkin-seed, from Washington, D. C., with the ctenoid area large, though the teeth are rudimentary; from Upper St. Croix River, Douglas County, Wisconsin (Grænicher), with widely spaced transverse apical circuli, and the ctenoid patch either wholly absent or reduced to a few marginal teeth of small size.

(3) Lepomis holbrookii (Cuvier \& Valenciennes), from the Carolinas, has the scale very broad (about $6 \frac{1}{3} \mathrm{~mm}$. long and $8 \frac{1}{2}$ broad), with the ctenoid features distinct; other scales, also from the Carolinas, are much narrower and less ctenoid.

(4) Lepomis cyanellus (Rafinesque), green sunfish, from Washington, D. C., and New Orleans, La., is conspicuously ctenoid when not latinucleate; from Woods Lake, near Greeley, Colorado (Warren), it is completely cycloid, with widely-spaced apical circuli.

It will be observed that these variations follow rather narrow lines, and the racial differences are of the same sort as the individual ones. It remains to be seen whether the apparent racial differences in scale characters, as in color and other features, are the direct result of environmental conditions, or indicate incipient species. It would seem likely enough that there are, in fact, a number of unrecognized subspecific types among the centrarchids, and the individual variability noted may be due in large part to the crossing of such types, which have remained distinct only as long as isolated.

The following systematic treatment mainly follows the lines of Jordan \& Evermann's work:

\section{Subfamily CENTRARCHIN无.}

Scales strongly ctenoid, the ctenoid patch very broad, though the teeth are very small; basal radii about 8 to I 2 ; apical circuli quite dense ...... Centrarchus macropterus (Lacépède) Dismal Swamp Scales cycloid or with a small ctenoid patch; apical circuli dense, not differing from the lateral ones... I I. Scales yellowish, about as long as broad; basal radii 6 to $12 \ldots \ldots \ldots \ldots \ldots \ldots \ldots \ldots$. . . . . . . . . . . . . annularis Rafinesque, Neosho River, Mo., and P. sparoides (Lacépède) New Orleans, La.

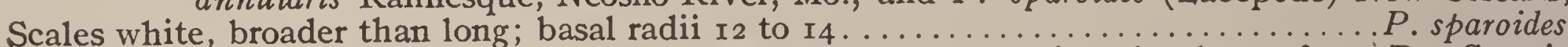
Sodus Bay, N. Y., and St. Croix River, Douglas Co., Wis., the latter from Dr. Grænicher.

Are there northern and southern races of $P$. sparoides? 
Subfamily LEPOMIN A:.

Tribe Ambloplitini. (P1. xxxvir, fig. 29, 30.)

Strictly cycloid, but the apical circuli widely spaced, and more or less strongly undulate or zigzag, as in Gerridæ............................... Acantharchus pomotis (Baird), Tarboro, N. C. Sharply ctenoid when young, but margin cycloid in adults........... Ambloplites rupestris (Rafinesque) With a small variously developed ctenoid area......... Chonobryttus gulosus (Cuvier \& Valenciennes) Very strongly and coarsely ctenoid.......................... plitini.

Thus Centrarchus stands at the base of the Centrarchinæ, and Archoplites at the base of the Amblo-

Tribe LEPomini. (P1. xxxviI, fig. 28.)

For the pharyngeal characters, see Bean \& Weed, Proceedings United States National Museum, volume 40, pages 369-376. On the scale characters, Enneacanthus stands at the base of this series.

Scales strongly ctenoid. ......................... Enneacanthus gloriosus (Holbrook) Scales moderately ctenoid, not so broad as those of Enneacanthus.

Mesogonistius chøtodon (Baird) Trenton, N. J. Scales feebly ctenoid, rarely practically cycloid, with no generic difference from the last, except that they are usually less ctenoid and have fewer basal radii........................ Lepomis

It seems impossible to make any key for the scales of the species of Lepomis; L. gibbosus, cyanellus, punctatus, auritus and some euryorus have the apical circuli more widely spaced than in the others. The species examined are L.cyanellus, punctatus, symmetricus, auritus, megalotis, pallidus, albus, heros, holbrooki, euryorus, gibbosus. The scale of L. megalotis (Lake Maxinkuckee, Ind.) is quite broad, with up to 2 basal radii, a larger number than is usual in the genus.

\section{Subfamily MICROPTERINA. Black basses.}

The genus Micropterus has been discussed above. The scales are the largest found in the Centrarchidæ, but Ambloplites runs them close. Ambloplites differs from Micropterus in having the adult scales conspicuously broader than long, with denser apical circuli. It is a question whether $M$. salmoides should not be called Aplites salmoides, or Aplites Rafinesque at least used in a subgeneric sense.

The following arrangement of the centrarchid genera is suggested: Centrarchus, Pomoxis; Aplites, Micropterus; Archoplites, Chanobryttus, Ambloplites, Acantharchus; Enneacanthus, Mesogonistius Lepomis.

\section{APHREDODERIDE. Pirate perches.}

\section{Subfamily APHREDODERINAs.}

Aphredoderus sayanus Gilliams. Houston, Tex. (Evermann). Scales about $2 \frac{1}{3} \mathrm{~mm}$. long and $\mathbf{r} 2 / 3$ broad, parallel-sided, with four very deep basal plications, the basal margin strongly scalloped; apical margin with a row of about 25 to 30 very long teeth, free only at apex; nucleus subapical; nuclear area with fine labyrinthiform markings; lateral circuli widely spaced, but with rudiments of others between them. This is very different from Percopsis, though agreeing in having a single row of apical teeth. Except for the ctenoid feature, there is a rather strong resemblance to Lucius. In the character of the ctenoid fringe, there is much resemblance to the ctenoid Characinidæ of Africa. The ctenoid structures in Percopsis and Aphredoderus are quite different from those in Perca, but a fairly intermediate type occurs in Pomacanthus arcuatus (Linnæus).

\section{Subfamily Trichophanines.}

Trichophanes foliarum Cope, from the Miocene shales of Florissant, Colo., has been discussed and figured in the American Naturalist, volume XLII, pages 570-574. It is there regarded as the type of a distinct family, but I now believe that it deserves only subfamily rank. The scales have a subapical 
nucleus, very coarse concentric circuli, and about 5 or more very long and strong sharp spines along the apical margin. Thus the scales agree in all essential features with those of Aphredoderus, and in their marginal teeth closely resemble Xenochares and Distichodus in the African characinid fauna.

The Aphredoderidæ seem quite out of place next to the Centrarchidæ. Jordan says of them: "Probably the most primitive of all living Percoid fishes, showing affinities with the Salmopercæ." Aphredoderus "agrees with the Berycoid fishes in scales and structure of the fins, and Boulenger places it with the Berycidæ." However, the resemblance to the berycoid scales is remote. In the Aphredoderidæ the apical teeth are articulated, as it were, on the margin, and in both the living and fossil fishes are movable. In the berycids they are instead rigid projections on the marginal area, into which they are basally prolonged.

Regan has recently referred the Aphredoderidæ to the Salmopercæ.

\section{KUHLIIDE.}

Kuhlia rupestris (Cuvier \& Valenciennes) from Mauritius (M. C. Z. 57 IO) has rather large subquadrate scales, about ro $\mathrm{mm}$. long and broad, the laterobasal corners rectangular, and the lower margin nearly straight. The nucleus is about $6 \mathrm{~mm}$. from

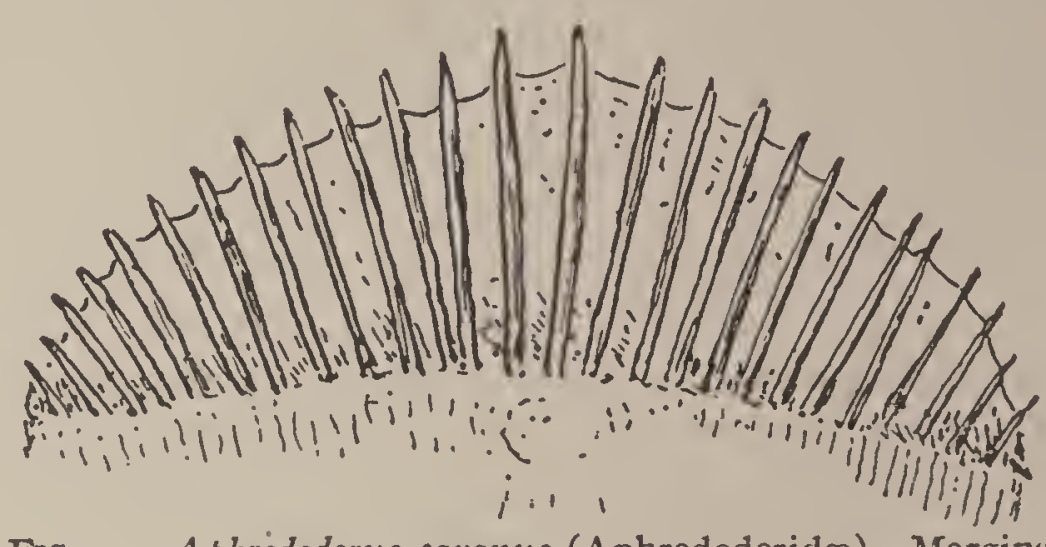

FIG. 13.-A phredoderus sayanus (Aphredoderidæ). Marginal teeth. Bureau of Fisheries.

the base; apical region typically ctenoid, of the usual Percoid type, the apical teeth numerous and sharp, the submarginal elements truncate (style of Lagodon in Sparidæ); basal radii delicate, about eleven. This agrees very well in general type with Lucioperca.

\section{PERCIDE. Perches.}

The typical percid scale is subquadrate, ctenoid, with nucleus apicad of the middle, and strong basal radii. The American subfamilies are separated on the scales as follows:

Basal radii many or few (e.g., 20 in some Hypohomus, 6 in some Boleosoma); basal margin not very deeply crenate; submarginal apical elements short and broad........... Etheostominæ

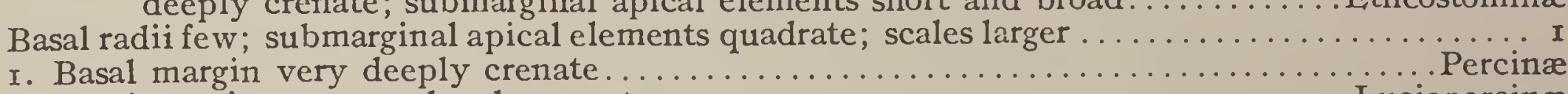

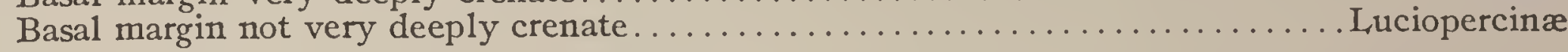

In the Old World we find the following subfamilies:

Basal margin very deeply crenate or lobed; dorsal fins distinct; no canine teeth (Perca)... Percinæ Basal margin moderately crenate or lobed $\ldots \ldots \ldots \ldots \ldots \ldots \ldots \ldots \ldots \ldots \ldots \ldots \ldots \ldots \ldots$

I. Submarginal apical elements short and broad; marginal teeth long (Zingel)...... Etheostominæ Submarginal apical elements longer, more quadrate; marginal teeth usually shorter........2

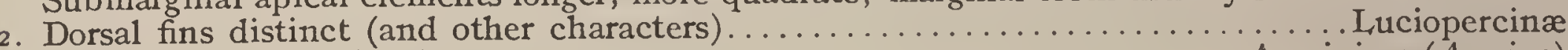

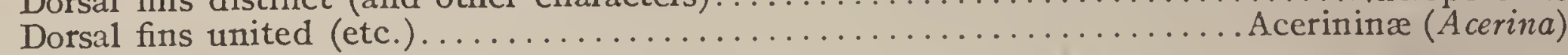

I have not examined the genus Percarina.

In spite of the great development of Percidæ in North America, the group must surely have originated in the Old World, because (I) it is more varied in type there, and (2) it is more difficult to separate the European subfamilies than the American on their scales. However, the palæontological evidence indicates considerable antiquity for the percids both in Europe and America, and even if it is true that the living American subfamilies are of Old World origin, this does not prove anything regarding the history of the much older forms known as fossils.

The Lucioperca-Acerina type of scale is doubtless the primitive one in the family. It is difficult to find much difference between the scales of these genera, so different in other respects; but in Acerina the submarginal apical elements are more conspicuously broadened basally, approaching the condition 
of the Etheostominæ very noticeably, whereas in Lucioperca they are more nearly as in Perca. This character varies, however, in Lucioperca, and in L. sandra Cuvier \& Valenciennes, from the Danube, the submarginal elements are quite short. L. volgensis Pallas, from Astrachan, has the submarginal elements conspicuously elongated. Boulenger unites the American Stizostedion with Lucioperca, and it is impossible to find any substantial difference in the scales. Curiously, the pike perch, Stizostedion vitreum (Mitchell) from Cedar Point, Toledo, Ohio, has the submarginal elements elongated as in $L$. volgensis; while S. canadense (C. H. Smith) from Big Sycamore Creek, Tenn., has them short as in $L$. sandra.

The species of Acerina examined are A. cernua Linnæus (Danube River and Switzerland) and $A$. schrotser Linnæus. I can not separate them on the scales. Acerina acerina (Perca acerina Gmelin) I have not seen. The genus $Z$ ingel Cloquet includes $Z$. zingel Linnæus, $Z$. asper (Linnæus) and $Z$. streber (Siebold), unless we follow Jordan, and recognize a second genus (Aspro Cuvier \& Valenciennes) for the second and third of these. I have $Z$. zingel and $Z$. streber. The scales of $Z$. streber, at least in my material, are smaller and shorter, otherwise there is no appreciable difference. Scales of $Z$. zingel (fish I0 $1 / 4$ inches long) are about $4 \mathrm{~mm}$. long and $3 \frac{1}{2}$ broad, therefore much larger than any of the American Etheostominæ, the largest of which are less than $2 \mathrm{~mm}$. long. In the larger American scales (Percini and Diplesion) the basal radii are much stronger than in Zingel, and more parallel. Jordan remarks that Zingel is perhaps the ancestor of the entire group of Etheostominæ.

Of Perca I have the three known species, European perch, P. Aluviatilis Linnæus, from Sweden; American perch $P$. flavescens (Mitchell), from Lyndonville, Vt., and Falmouth, Mass.; $P$. schrenkii Kessl

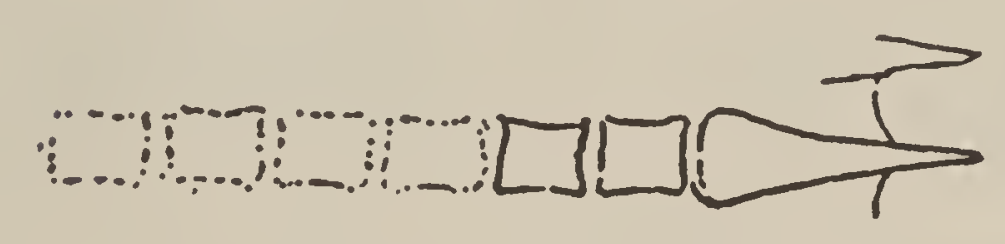

Fig. 14.-Percaflavescens (Percidæ). Ctenoid structures. Bureau of Fisheries. from Khuldscha. P. Auviatilis (fish $\mathrm{I} 7$ inches long) has large reddish scales, fully ro $\mathrm{mm}$. long, with six basal radii; basal margin deeply cut into long lobes; apical teeth short; subapical elements quadrate, but not elongated. P. flavescens (fish 6 inches long) has colorless scales about $4 \mathrm{~mm}$. long; six basal radii; lobes of basal margin not so long; apical teeth short; subapical elements distinctly elongated. In $P$. schrenkii the scale is about the same size as that of $P$. flavescens, but longer, and broader above the middle than at the base, the reverse being conspicuously true of $P$. flavescens. The basal radii are three to six, and the lobes of the basal margin are shorter than in either of the other species. The apical marginal elements are distinctly elongated. Scales of $P$. schrenkii are readily known from those of Lucioperca volgensis by their peculiar form, narrowing below (basad), the shorter apical teeth, and the much more strongly crenate base.

It seems quite impossible to make a key to the genera or species of American darters, Etheostominæ. I give a list of the species studied, with some notes.

Percina caprodes (Rafinesque), log perch. Chili, Ind. Scales about I $1 / 2$ (some $13 / 4$ ) mm. long, and about as broad; about 6 to ro basal radii; apical teeth long.

Hadropterus phoxocephalus (Nelson). Durkey's Ferry, Wabash River, Ind.

H. macrocephalus (Cope). Obeys River, Olympus, Tenn.

H. aspro (Cope \& Jordan), black-sided darter. Upper Eel River, Allen Co., Ind.

$H$. guntheri (Eigenmann \& Eigenmann). Cheyenne River, Valley City, N. Dak.

$H$. peltatus (Stauffer). Neuse River, Raleigh, N. C.

H. ouachitce (Jordan \& Gilbert). Marked Tree, Ark.

H. scierus Swain. Tippecanoe River, Marshland, Ind.

H. roanoka (Jordan \& Jenkins). Neuse River, Raleigh, N. C. "Cotype."

H. maxinkuckiensis Evermann. Lake Maxinkuckee, Ind.

All have small scales with quite long apical teeth. They differ in size; thus $H$. macrocephalus has scales hardly over I mm. long, while $H$. peltatus has them fully I. $5 \mathrm{~mm}$., the fishes in each case being 3 inches long. H. peltatus and scierus have scales of about the same size, but the apical teeth are distinctly longer in scierus. 
Hypohomus spilotus (Gilbert). Hector Creek, Ky. (Woolman). Scales known from those of Hadropterus by the very large number of basal radii.

Cottogaster uranidea (Jordan \& Gilbert). Vincennes, Ind.

C. copelandi(Jordan). Iowandi, $\mathrm{Ky}$.

C. shumardi (Girard). Durkey's Ferry, Wabash River, Ind.; also Wabash River, Ind. (Evermann).

C. cheneyi Evermann \& Kendall. Rackett River, N. Y. "Cotype." This genus has small scales like those of Hadropterus, with the basal radii only moderately numerous (e. g., 9 or Io), but the scales are conspicuously broader than long, averaging considerably shorter than those of Hadropterus.

Ulocentra stigmcea (Jordan). Obeys River, Olympus, Tenn.

$U$. gilberti Evermann \& Thoburn. Walker's Ford, Clinch River, Tenn. "Cotype."

$U$. meadic Jordan \& Evermann. Indian Creek, Tenn. "Cotype."

$U$. histrio (Jordan \& Gilbert). Black Rock, Rock River, Ark.

$U$. simotera (Cope). Mount Verde, Tenn.

$U$. "probably new." Arnwine Creek, Athens, Tenn. 23/4 inches long.

Ulocentra has broad scales like those of Cottogaster, but the basal radii are more numerous (generally about 12), and the apical teeth are shorter, usually very short. $U$. stigmcea has very broad scales, some almost twice as broad as long, whereas in $U$. gilberti they are mostly not greatly broader than long.

Diplesion blennioides (Rafinesque), green-sided darter. Murfreesboro, Tenn., 5 inches long. Scales $x \frac{1}{2} \mathrm{~mm}$. long and broad, with long apical teeth and about a dozen basal radii. The scales are larger than those of Ulocentra, Cottogaster, etc., but so is the fish. I can not satisfactorily distinguish Diplesion scales from those of Percina.

Boleosoma longimanus (Jordan). Lexington, Va.

B. podostemone (Jordan \& Jenkins). Roanoke River,Va. "Cotype."

B. nigrum (Rafinesque). Osterville, Mass., and Columbia City, Ind.

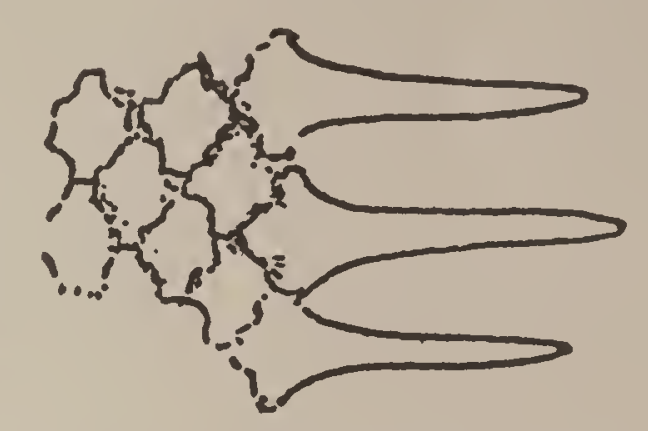

FIG. I5.-Cottogaster shumardi (Percidæ). Ctenoid structures. Bureau of Fisheries.

In this genus the scales are broader than long, with about a dozen basal radii.

Crystallaria asprella (Jordan). Wabash River, Ind. 3 inches long; extremely small, rather broad scales, with long apical teeth.

Ammocrypta pellucida (Baird), sand darter. Adamsboro, Ind. 3 inches long.

A. beanii Jordan. Greenville, Ala. $23 / 4$ inches long. The scales of this genus are also extremely minute, almost rudimentary.

Ioa vitrea (Cope). Raleigh, N. C. Scales minute, with long apical teeth; the principal character is found in the very widely spaced lateral circuli. The last three genera are the weakest scaled in the family.

Etheostoma. In this large genus the scales are of the same type as those of related genera, with pigment spots along the bases of the apical teeth, such as are found in other American Etheostominæ, in $Z$ ingel, and even in Acerina cernua. The basal radii vary from 9 (zonale, flabellare) to 16 (some pottsii, julice, and iowa). In some species the scales average about as broad as long (punctulatum), in others they are conspicuously broader than long (julice, pottsii), but in no case are they longer than broad, if we take scales from the middle of the side and measure only to the bases of the apical teeth. In some the scales are comparatively large (variatum), in others very small (flabellare). After measuring what seemed to be fair average scales of each species, I have thrown my results into the following key, but it must be clearly understood that while it is indicative of general tendencies or types, it is not at all reliable for the determination of the species. 
The following abbreviations are used: long., lat., length and breadth; ap., length of longer apical teeth; b. r., number of basal radii; measurements all in microns, except the length of the fish.

A. Length of scale less than 800 .

a. Breadth of scale same as length.

E. flabellare Rafinesque, fan-tailed darter ( $\mathrm{i}$ inch). Cumberland Gap, Tenn.; long. and lat. 590; lateral radii very widely spaced; 9 b. r.

E. punctulatum (Agassiz) ( 1 inch). Marshfield, Ind.; long. and lat. 655; ap. 95; Io b. r.

$b$. Breadth of scale much greater than length.

$i$. Scale very broad; pigment spots along margin light brown.

E. lepidum (Baird \& Girard) (I $1 / 2$ inch). New Braunfels, Tex.; long. 770, lat. I 50 ; I $2-14$ b. r.

ii. Scale moderately broad.

E. australe Jordan. ( $\mathrm{I} / 2$ inch). Chihuahua, Mexico; very widely spaced circuli around nucleus; long. 775, lat. 935 ; ap. 95; I 2 b. r.

E. camurum (Cope) blue-breasted darter (23/4 inches). Marshland, Ind.; long. 705, lat. 880; ap. 95 ; 10 b. r.

E. tippecanoe Jordan \& Evermann (2 inches). Marshland, Ind.; long. 750, lat. $865 ; 9-12$ b. r.

B. Length of scale 800 to $\mathrm{I}, 040$.

a. Scale about as broad as long.

E. cragini Gilbert (I inch). Garden City, Kansas; "cotype”; long. 815, lat. 830; ap. 95 ; 12 b. r.

E. jessie (Jordan \& Brayton). Long. 1040, lat. 1055; ap. I45; I I-I4 b. r.

E. whipplii (Girard). (I $1 / 2$ inch). Kaimishi, I. T.; long. and lat. 800 ; I0-I I b. r. $b$. scale evidently broader than long.

$i$. Basal radii 9 .

E. zonale (Cope) ( $13 / 4$ inch). Cumberland Gap, Tenn.; long. 990, lat. rogo.

ii. Basal radii more than $I 0$.

E. iow Jordan \& Meek. Creighton, Nebr.; long. 800, lat. I040; ap. 80; I4-I6 b. $r$.

E. obeyense Kirsch (I $\mathrm{x} / 4$ inch). Cumberland River, Wayne County, Ky.; long. 865, lat. 945 ; ap. 95 ; I I-I3 b. r.

E. pottsii (Girard). ( $13 / 4$ inch). Chihuahua, Mexico; long. 960, lat. $1250 ; 15^{-16}$ b. $r$.

E. julice Meek. Springfield, Mo.; long. I040, lat. I295; I3-I6 b. r.

E. boreale (Jordan) ( $2 \frac{1}{4}$ inch). Michigamme, Mich.; long. 925 , lat. roro (another, long. 880, lat. 925); I2-I4 b.r.

C. length of scale over 1040 .

a. Length of scale $\mathrm{I} 490$, breadth the same.

E. variatum Kirtland ( 2 inches). Blue River, Wyandotte Cave, Ind.; I I b. r.

$b$. Length of scale not over I330.

E. swannanoa Jordan \& Evermann ( $\mathrm{I} / 2$ inch). Black Mountain, N. C. ; long. I055, lat. I280; IO-I3 b. r.

E. squamiceps Jordan ( $1 / 2$ inch). Murfreesboro, Tenn.; circuli around nucleus not very widely spaced; long. I3 Io, lat. I375; ap. 72; I4 b. r.

E. jordani Gilbert ( 2 inches). Oxford, Ala.; "cotype;" circuli around nucleus very widely spaced; long. II70, lat. I360; ap. II0; 9-I2 b. r.

E. cinereum Storer ( $3 \frac{1}{2}$ inches). Olympus, Tenn.; long. I330, lat. I345; ap. I 28 ; 12 b. $r$

E. coeruleum Storer, blue darter. (I $1 / 2$ inch). Neosho, Mo.; long. I I20, lat. I440; ap. I45; I I-I 5 b. r.

E. rufilineatus (Cope) (23/4 inches). Knoxville, Tenn.; long. II5O, lat. I200; ap. 145 ; 13 b. r.

It will be observed that there is very little correspondence between this arrangement and the subgenera recognized by authors. It is certain that the scales are of very minor value in the taxonomy of this group, and no doubt individual variation oversteps most of the limits suggested by my data. At the same time there are good average differences between several of the species; thus, when we compare the species, E. pottsii and E. australe, both from Chihuahua, it is evident that pottsii has larger and broader scales, and the difference is greater than can be accounted for by the somewhat larger size of the fish. It is probable that if statistical studies are made of numerous scales, some help will be obtained for the separation of closely allied species.

Psychromaster tuscumbia (Gilbert \& Swain). Tuscumbia, Ala. Scales broader than long, not differing from those of Etheostoma. 
Boleichthys fusiformis (Girard). St. Francisco River, Ark. Scales broader than long, like those of Etheostoma, with prominent rectangular laterobasal corners; basal radii about I2 to I4.

Microperca punctulata Putnam. Lake Maxinkuckee, Ind. Scales very small, conspicuously broader than long (length about $765 \mu$, breadth I040); about II to I4 basal radii. Easily known from Boleichthys scales by the smaller size and obtuse laterobasal corners.

$M$. fonticola (Jordan \& Gilbert). San Marcos, Tex. Scales like those of M. punctulata.

For the North American percid scales described above I am indebted to the Bureau of Fisheries, and for the European species to the National Museum, in each case through Dr. H. M. Smith.

In general, the scales of the Percidæ are quite distinct from those of the Centrarchidæ, though of the same essential character. The scales of the two families approach in such genera as Archoplites and Lucioperca ( $L$. sandra), but in the Archoplites the nucleus is not so far apicad as in the other.

The Validity of Boleosoma olmstedi (Storer), as Indicated by its Scales. BY T. D. A. COCKERELI, AND MARY ESTHER ELDER.

We recently received from the Bureau of Fisheries some scales of Boleosoma olmstedi (Storer), a form which has been treated as a subspecies of B. nigrum, but which Dr. W. C. Kendall believes to be a valid species. It was suggested that perhaps the scales might

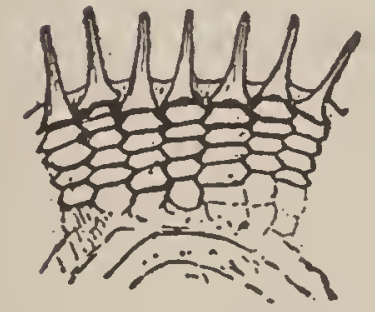

Fig. 16. - Boleosomanigrum. Apicalmargin.

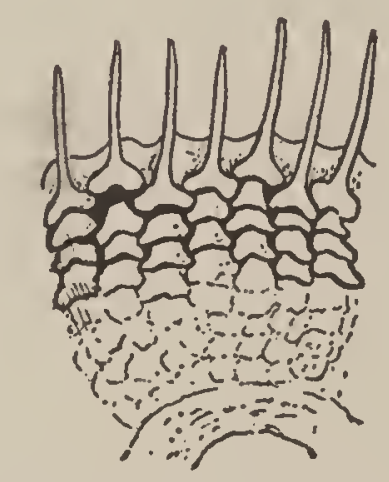

FIG. I7.-Boleosoma po. dostemone. A pical margin.

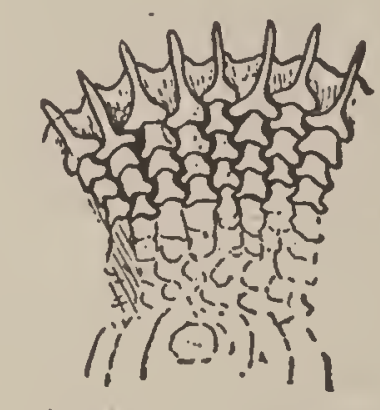

FIG. I8.-Boleosome olmstedi. A pical margin. From specimen $3 \frac{1}{16}$ inches long.

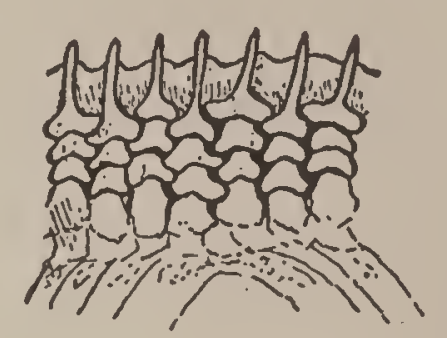

FIG. 19.-Boleosoma olmstedi. Apical margin. From specimen $15 / 8$ inches long.

afford characters which would throw light on the question of the distinctness of $B$. olmstedi. We hardly expected positive results, on account of the undoubted affinity of the fishes, but a study of the material shows that, at least so far as our material goes, the scales of $B$. nigrum and olmstedi are readily separable. The observed difference can not well be a matter of age, as olmstedi scales were examined from fishes $\mathrm{I} 5 / 8$ inch and $3 \frac{1}{16}$ inches, respectively, while the $B$. nigrum scales came from a fish $2 \frac{1}{4}$ inches long. We also took occasion to compare scales of $B$. podostemone (cotype fish, $\mathrm{I} 3 / 4$ inches long), and found good characters to distinguish them from those of the others. The scales of the three may be diagnosed as follows:

(r) Boleosoma nigrum (Rafinesque). Columbus City, Ind. Apical teeth rather long, the greater part free from the marginal membrane; subapical elements below the teeth transversely elongated, and usually in four rows.

(2) Boleosoma podostemone (Jordan \& Jenkins). Roanoke River, Va. Apical teeth very long, the greater part free from the marginal membrane; subapical elements below the teeth in two or three distinct rows, subtriangular in form.

(3) Boleosoma olmstedi (Storer). Falmouth, Mass. Apical teeth moderate, less than half free from the marginal membrane; subapical elements below the teeth in two or three distinct rows, subtriangular. 


\section{APOGONIDE. Cardinal fishes.}

In Apogonichthys pomarce Steindachner from the Society Islands (M. C. Z. 9698), the reddish scales are much broader than long, length about $4 \frac{1}{2} 2$, breadth about $5 \frac{1}{4} \mathrm{~mm}$.; general character percoid; 12 to 16 basal radii; laterobasal corners obtuse; lateral circuli numerous, oblique, running to the margin; apical teeth moderate; submarginal elements longer than broad, emarginate basally. Differs at once from Lucioperca, Centropristes, etc., by the oblique lateral circuli. The beginning of this obliquity is seen in Percichthys.

\section{SERRANIDE. Sea basses. (P1. xxxvIr, fig. 32.)}

The North American genera examined can be divided into subfamilies as follows:

Serraninæ (Paralabrax, Centropristes). Apical marginal spines truncate.

Epinephelinæ (Epinephelus). Apical marginal spines obtusely pointed, margined. Scales much longer than broad.

Moroninæ (Morone, Roccus). Apical marginal spines pointed or (adult Morone) minutely bifid at tip. Roccus is easily separated from Morone by the very numerous basal radii.

Another subfamily (Percichthyinæ) must be recognized for the freshwater genus Percichthys Girard, in which the adult scales are longer than broad, parallel-sided, with the broadly rounded apical margin entire, although there is a submarginal ctenoid patch, beset with spines.

Still another subfamily (Plesiopinæ) must contain Plesiops Cuvier, of which $\mathrm{I}$ have $P$. corallicola from the Ebon Islands (M. C. Z., 2473). The scale is $7 \mathrm{~mm}$. long and $6 \mathrm{~T} / 2$ broad, the exposed part covered with dark purplish skin. Laterobasal angles obtuse; nucleus in the submarginal apical region, and from it radiate about ${ }_{5}$ long basal radii; lateral circuli dense, slightly oblique; apical marginal teeth slender, more or less obtuse or truncate at end; subapical elements narrow and elongate. This is nearer to Centropristes than to any of the other scales cited above. A lateral line scale of $P$. corallicola is curiously different, with the nucleus much further down, and having strong apical as well as basal radii Boulenger makes $P$. corallicola a synonym of $P$. nigricans (Ruppell).

Scales of Aulacocephalus schlegelii Günther ( $A$. temminckii Bleeker) are figured by Sauvage in his work on the fishes of Madagascar. They somewhat approach those of Epinephelus.

\section{Subfamily PERCICHTHYINA. The truchas.}

My material of this group is from the United States National Museum.

Percosoma melanops (Girard). Santiago, Chile; $4 \frac{7}{8}$ inches long. Scales reddish, about $3 \mathrm{~mm}$. long and 2 broad; parallel-sided, with the laterobasal corners more or less projecting downwards; nucleus about $2 \mathrm{~mm}$. from base; 6 to 9 basal radii; lateral circuli coarse, somewhat oblique; ctenoid patch very variable in size, with long narrow elements, some of which occasionally project as spines over the margin.

Percichthys trucha (Cuvier \& Valenciennes). South America; 12 $1 / 4$ inches long. Scales reddish, the larger ones about $5 \mathrm{r} / 4 \mathrm{~mm}$. long and $43 / 4$ broad; nucleus about $3 \mathrm{~mm}$. from base; basal margin slightly convex, delicately crenate; apical field as in Percosoma. In latinucleate scales there is no ctenoid patch, and the widely spaced apical circuli run right across, parallel with the broadly rounded margin.

A young fish, $5 \frac{1 / 4}{4}$ inches long, from Argentina, has scales less than $2 \mathrm{~mm}$. long, but still without projecting apical spines.

Although this fish is closely allied to Percosoma, the latter is readily separated by the long and narrow scales.

Percichthys chilensis (Girard). Santiago, Chile; $73 / 4$ inches long. Boulenger makes this a synonym of $P$. trucha, and the scales seem the same, though the basal radii may average somewhat less. 
Subfamily SERRANINEE. Sea basses. (P1. XxxvIr,fig. 31.)

The following have been examined:

Centropristes striatus (Linnæus), black sea bass. Woods Hole, Mass. Scales subquadrate, about $8 \mathrm{~mm}$. long and broad; ctenoid area very beautifully developed; apical teeth truncate and often broadened at base; nucleus subapical; basal radii 9 or ro; lateral circuli running parallel with margin.

Paralabrax maculofasciatus (Steindachner), spotted cabrilla. Guaymas, Mexico (Albatross). Scales about $4 \mathrm{~mm}$. long and $23 / 4$ broad, the long, parallel-sided form very different from that of Centropristes; basal radii 8 to II.

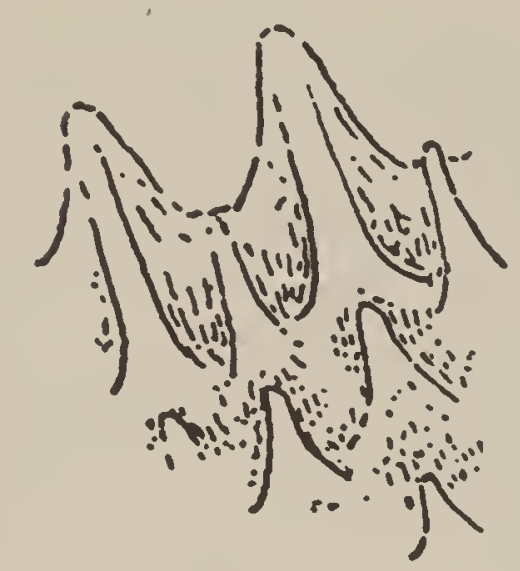

Fig. 20.-Epinephelus niveatus (Serranidæ). Ctenoid structures. Burea u of Fisheries.

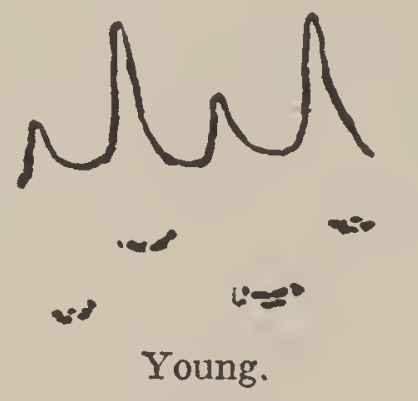

FIG. 21.-Morone americana (Serranidæ). Ctenoid structures. Bureau of Fisheries.

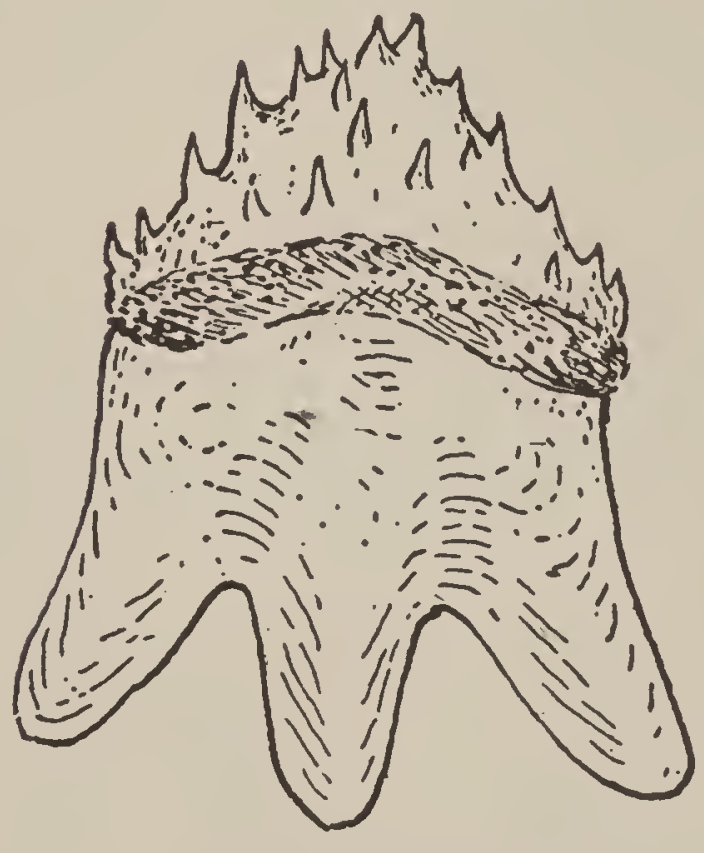

FiG. 22.-Priacanthus (Priacanthidæ). Bureau of Fisheries.

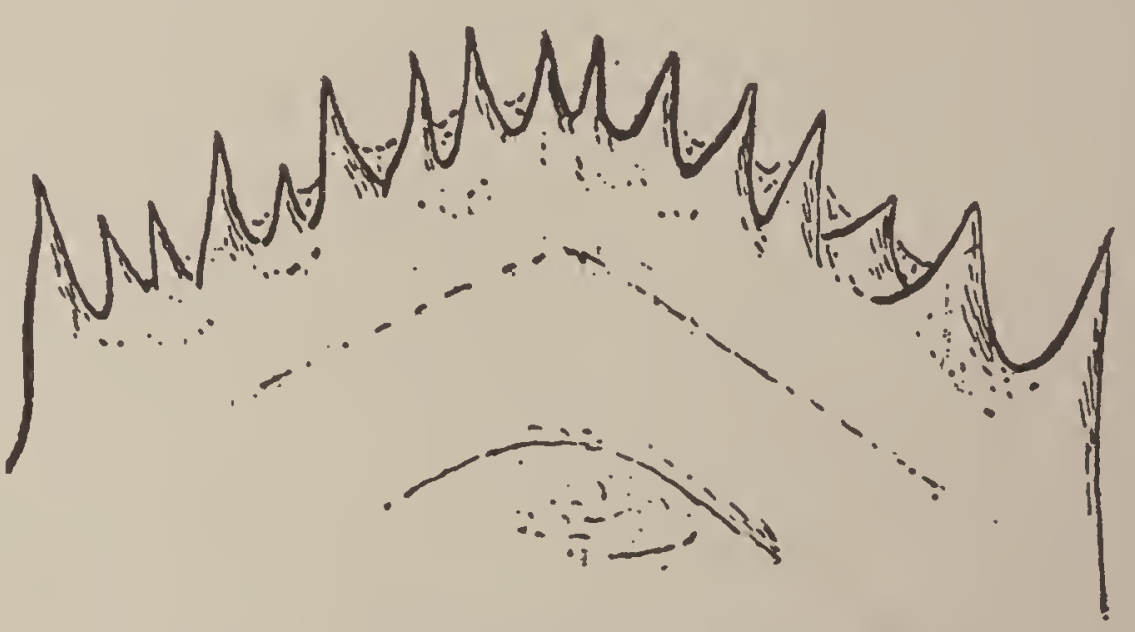

FIG. 23.-Pseudopriacanthus altus (Priacanthidæ). Bureau of Fisheries.

Paralabrax clathratus (Girard), cabrilla. San Diego Bay (Albatross). Scales similar, but smaller, and somewhat broader in proportion to their length. In both species of Paralabrax the scales are white; the finely mottled skin has the pigment light ferruginous in $P$. maculatofasciatus, purplish-brown in P. clathratus.

\section{Subfamily EPHINEPHELINAE. Groupers.}

Epinephelus niveatus (Cuvier \& Valenciennes), snowy grouper, from Katama Bay, has scales which remind one of Paralabrax, but the basal radii are only 4 to 6 , and the apical area is quite different, with the spines much reduced in number, but larger. 
Subfamily MORONINAs. White perches.

The characters of Roccus and Morone are given in the table of Acanthopterygian scales on an earlier page.

LOBOTIDE. Flashers.

The flasher, Lobotes surinamensis (Bloch) has large subquadrate reddish scales, which resemble those of Roccus in the very numerous basal radii. Other characters are given in the table just cited.

\section{PRIACANTHIDA. Catalufas.}

Two subfamilies may be distinguished as follows:

Priacanthinæ (Priacanthus). Scales very strongly trilobed at base; apex produced, with irregularly placed teeth.

Pseudopriacanthinæ (Pseudopriacanthus). Scales quadrate (the apical margin produced to an obtuse angle), the base not at all trilobed, but its middle third crenate from the 5 or 6 basal radii; marginal teeth sharp and irregular, but not so irregular as in Priacanthus.

All the specimens examined are from Woods Hole, Mass. The Pseudopriacanthus is P. altus (Gill). The Priacanthus is presumably $P$. arenatus Cuvier \& Valenciennes, with which it agrees in fin rays, color of fins, etc., but it has a large serrate preopercular spine, as in $P$. cruentatus (Lacépède).

\section{LUTIANIDE. Snappers.}

The scale of the gray snapper, Neomænis griseus (Linnæus), from Tampa, Fla., has been figured in Proceedings of the Biological Society of Washington, volume xxmI, page 9r. The mutton fish, $N$. analis (Cuvier \& Valenciennes) is included in the table of Acanthopterygian scales above. The scale of $N$. griseus figured was much worn, and had lost the apical teeth, but the figure shows well the numerous basal radii, the lateral circuli running parallel with the margin, etc.

\section{HAMULIDE. Grunts. (P1. Xxxvir, fig. 33.)}

In the pigfishes, Orthopristis, the marginal teeth are truncate; in the grunts, Hamulon, and the burritos, Brachydeuterus, they are pointed. From these and other characters perhaps two subfamilies (Orthopristinæ and Hæmulinæ) may be indicated. Jordan \& Evermann say of the Hæmulidæ: "The group is very close to the Lutianidæ on the one hand and to the Sparidæ on the other, while some of its members show affinities with some Sciænidæ and Serranidæ." In its scales Orthopristis resembles some Sciænidæ, as the croakers Micropogon.

The scale of Anisotremus virginicus (Linnæus) is figured in Proceedings of the Biological Society of Washington, volume XXIII, page 92 .

\section{SPARIDE. Porgies.}

I have examined scup, Stenotomus chrysops (Linnæus) from Woods Hole, Mass., and pinfish, Lagodon rhomboides (Linnæus). Both have large scales, those of Lagodon quadrate, about as broad as long, those of Stenotomus much broader than long. The broad apical field has the usual Acanthopterygian sculpture feebly indicated, but only the

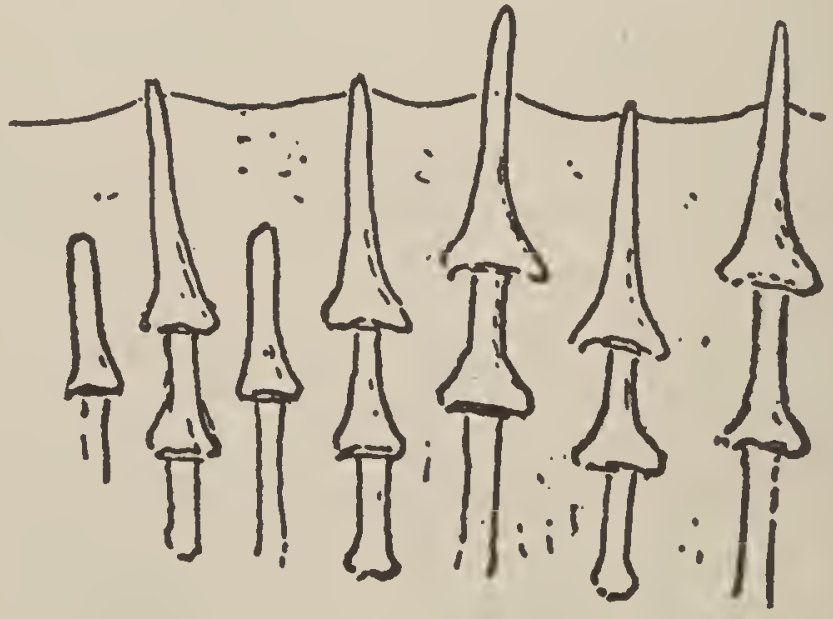

FIG. 24.-Neomanis analis (Lutianidæ). Bureau of Fisheries. margin is distinctly sculptured, with the well-formed elements in two (Stenotomus) or three (Lagodon) rows. This condition leads in the direction of that found in the Gerridæ. The basal radii are $\mathrm{I} 2$ in Lagodon, I3 or fewer in Stenotomus. The apical structure is nearly as in the coral fishes, Pomacentridæ, while both resemble the surmullets, Mullidæ. The scale of Lethrinus, as figured by Günther, has very well-developed sculpture in the apical field, with I $3_{3}$ or I4 rows of minute teeth. 
In Box vulgaris (Vienna Museum; M. C. Z.) the scales are about $3 \frac{1 / 4}{4 m}$. long and $5 \frac{1}{4}$ broad, with the nucleus central and about ro widely spreading basal radial folds. This is much like Stenotomus, differing in the less apical nucleus; the sloping sides, making the lower margin the broadest part; the broad apical region with the small quadrate elements distinct over the greater part, with no marked difference between the marginal and submarginal ones; and the much more oblique lateral circuli. (P1. XxxviII, fig. 34.)

Dr. G. A. Boulenger kindly collected for me scales of Dentex vulgaris Cuvier, from a fish 2 feet ro inches long, in the Grimsby Market. The scales vary very much in size and form; a large one is about $2 \mathrm{rmm}$. long and 27 broad; an unusually broad one is about $\mathrm{I}_{3} \mathrm{~mm}$. long and $2 \mathrm{I}$ broad; another is $\mathrm{I}_{5} 1 / 2$ long and 18 broad. These all come from the side of the fish. The circuli are excessively fine, and the lateral ones are little oblique, whereas in Box they are extremely oblique, reaching the margin at a large angle. The basal radial system is variably and of ten poorly developed, and the radii are not very numerous. The apical margin appears cycloid, but the apical field has a fine half obliterated honey-comb-like

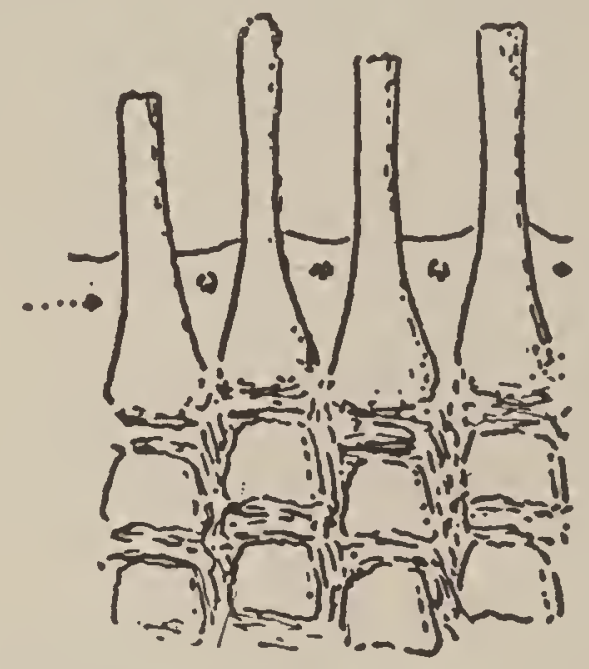

Fig. 25.-Orthopristis chalceus (Hæmulidæ). Ctenoid structures. The spots between the teeth are ferruginous pigment spots. Bureau of Fisheries.

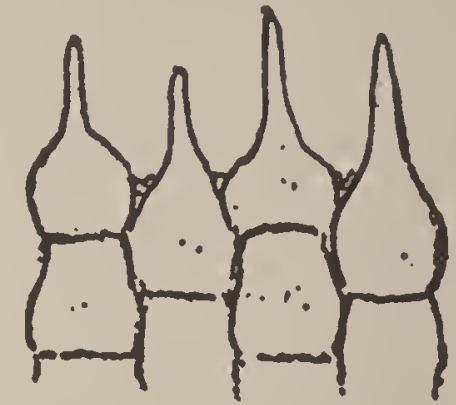

FIG. 26.-Stenotomus chrysops (Sparidæ). Ctenoid structures. Bureau of Fisheries.

structure representing the ctenoid patch. Curiously, the skin over the apical field is marked with a very distinct network of polygonal cells, corresponding to the structure beneath. The nucleus is apical of the middle.

In Dr. A. S. Woodward's Catalogue of Fossil Fishes (Igor), and in earlier works, Dentex appears among the Percidæ (sens. lat.). Dr. Woodward states that Dentex, Gerres, etc., are intermediate between the Percidæ and Sparidæ.

\section{MENIDE. Picarels. (P1. xxxvIr, fig. 35.)}

I have the scales of an undetermined species of Smaris (Spicara) from Trieste (M. C. Z., ro436). They are about $21 / 2 \mathrm{~mm}$. long and $32 / 3$ broad; nucleus a little above the middle; about ro strong widely spreading basal radii; sides sloping, so that the base is much the widest part; lateral circuli extremely oblique, but wanting in upper lateral region; apical margin strongly angled in the middle; apical marginal teeth sharp, and below them about two rows of broad subquadrate elements, below which the apical field is almost without sculpture.

This may be regarded as an extreme development of the type of Box. The oblique lateral circuli also suggest Apogonichthys, which is, however, very different in the apical region.

\section{GERRIDAE. Mojarras.}

The "broad shad," Xystama cinereum (Walbaum), from La Paz Harbor (Albatross) has transversely oval or oblong scales about $6 \mathrm{~mm}$. long and 7 broad, the laterobasal corners rounded, and the basal radii few (about 5 ) and more or less irregularly placed. The lower margin is only feebly crenate. The thin apical field shows rudiments of the usual ctenoid structures of Acanthopterygians, reduced to $89970^{\circ}-13-4$ 
irregurar transverse lines and small marginal denticulations. The lateral circuli are transverse, entirely in the manner of a clupeid. This last character is remarkable; a certain approach to it is found in Stenotomus (Sparidx), in which the upper lateral circuli are obliquely directed outward, pointing to the anterolateral angles.

The scales of the silver jenny, Eucinostomus gula (Cuvier \& Valenciennes), from Rio Grande do Sul, Brazil (M. C. Z., I6452) are so exactly like those of $X$. cinereum that I am at a loss to describe any difference. Scales of E. gula from Tampa, Fla., received from Dr. Grænicher, differ by having the apical field almost entirely covered with transverse circuli (not so dense as those elsewhere), and the ctenoid patch hardly indicated by even a rudiment. It is possible that northern and southern races of E. gula exist? (P1. xxxvin, fig. 36.)

\section{KYPHOSIDE. Chopas.}

The "chopa blanca" or Bermuda chub, Kyphosus sectatrix (Linnæus) from Menemsha Bight, Mass., shows a modified type of acanthopterygian scale, with a thickened band with hyaline dots across the middle, and the apical area having a grooved appearance. There are two rows of distinct elements on

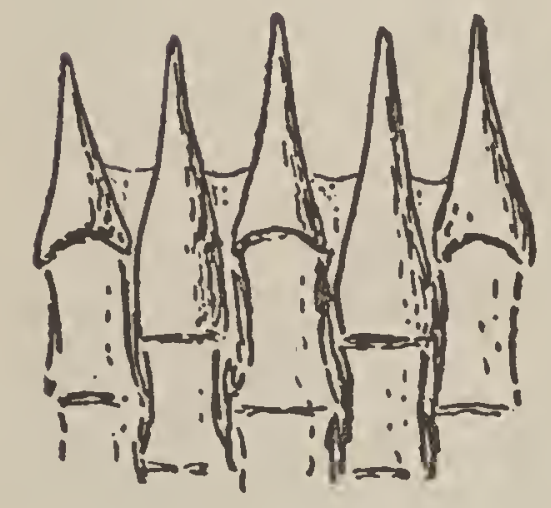

FIG. 27.-Lagodon rhomboides (Sparidæ). Ctenoid structures. Bureau of Fisheries.

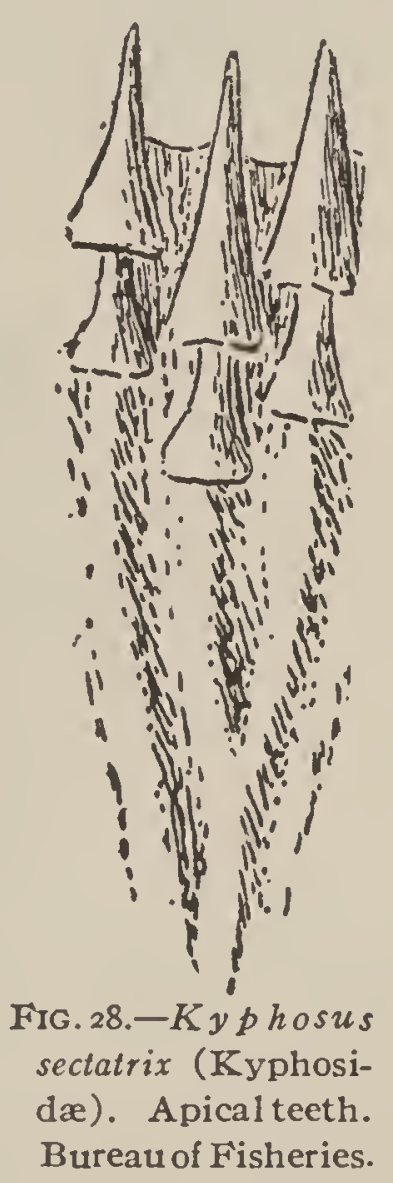

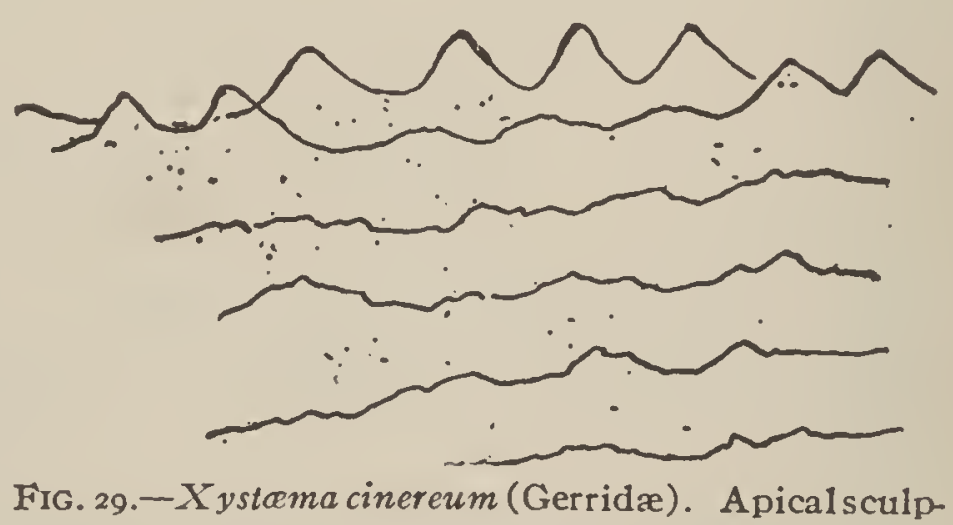

ture. Bureau of Fisheries.

the apical margin, the outermost ending in sharp teeth, and all triangular at base, approaching the condition found in Neomænis (Lutianidæ) and Chætodon (Chætodontidæ). The scales are broad-quadrate, rounded apically, with rectangular lower corners; length of scale about $5 \mathrm{~mm}$., breadth about $5^{\mathrm{I}} / 2$. The basal radii are very few, 4 to 6 . A constant peculiarity is the concavity of the sides of the apical margin. The lateral circuli are parallel with the margin.

This family is evidently not allied to the Gerridæ.

\section{MULLIDEE. Surmullets or goatfishes.}

The characters of Mullus, Upeneus, and Mulloides have been given in the table of acanthopterygian scales above. In all these genera the lateral circuli are more or less oblique, and the basal radii are few.

SCIENIDE. DRUMS.

Two subfamilies can be separated as follows:

Otolithinæ (Cynoscion), the weakfishes. Elements of apical marginal and submarginal area with a median keel or ridge. 
Sciæninæ (Leiostomus, Micropogon, Menticirrhus), the drums. Elements of apical marginal and submarginal area without any definite median keel or ridge; apical teeth pointed (Menticirrhus) or truncate.

The specific characters are given in the table of acanthopterygian scales above. In all the lateral circuli run parallel with the margin. The squeteague Cynoscion regalis is quite different from the

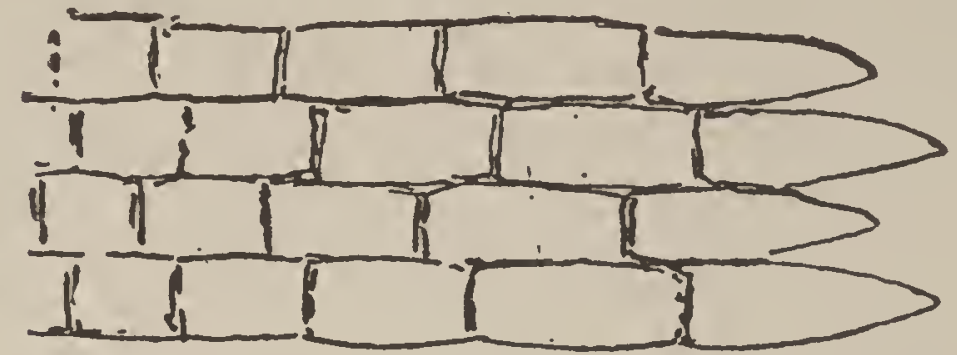

FIg. 30.-U peneus (Mullidæ). Ctenoid area. Bureau of Fisheries.

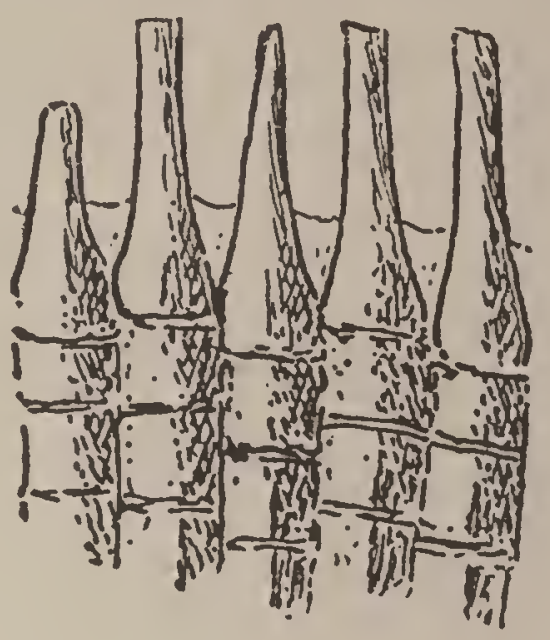

Fig. 3T.-Micropogon undulatus (Sciænidæ). Apical teeth. Bureau of Fisheries.

others by the very numerous and densely placed basal radii, which, however, occupy only about the middle third of the scale. In all the apical elements run conspicuously in straight lines, producing a sort of fluted effect.

\section{LATILIDE. Blanquellos.}

In the tilefish Lopholatilus chamceleonticeps Goode \& Bean, from the Gulf Stream, the scales are subquadrate, the larger ones about $9 \mathrm{~mm}$. long and 8 broad, the laterobasal corners rectangular. Nucleus subapical; about five basal radii coming from the nucleus, but several of these are branched, and there are a few incomplete radii, so that about $\mathrm{I}_{3}$ reach the margin; lower margin crenate; lateral circuli coarse, not dense, parallel with the margin; apical ctenoid field very well developed, the marginal teeth

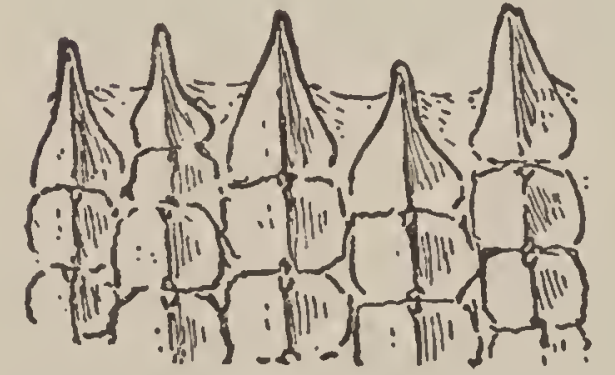

Fig. 32.-Cynoscion regalis (Sciænidx). A pical teeth. Bureau of Fisheries.

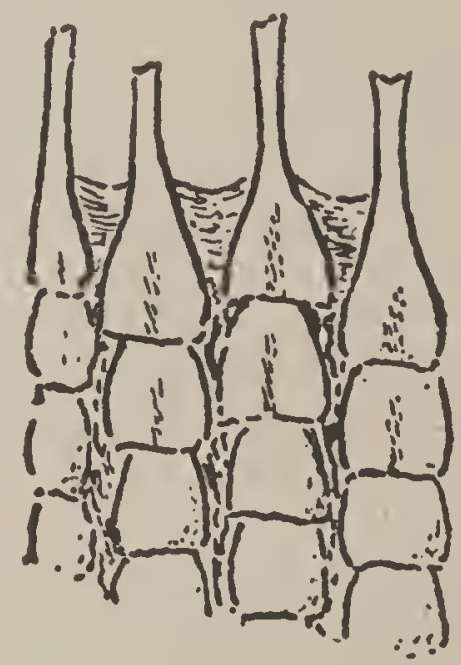

A.

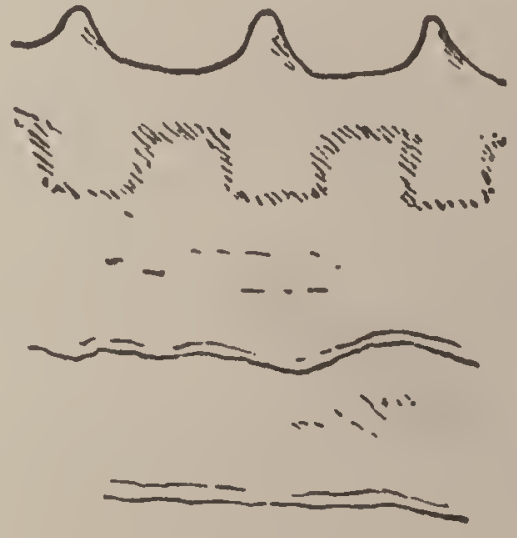

B.

FIG. 33.-Lopholatilus chamaleonticeps (L,atilidx). Apical structures. A, normal scale; B, latinucleate scale. Bureau of Fisheries.

truncate. Latinucleate scales are greatly modified, and would not be recognized as coming from the same fish.

\section{CIRRHITIDE. Cirrhitoids.}

Cirrhitichthys maculatus Günther from the Red Sea (M. C. Z., 3686) has large broadly rounded scales, about $9 \mathrm{~mm}$. long and $10 \mathrm{I} / 2$ broad, with the lower margin crenate, but otherwise straight, and the laterobasal corners rectangular. The strong basal radii are about I 2 to 14 . The excessively fine lateral 
circuli are strictly parallel with the margin, and the apical field has coarse, widely spaced longitudinal circuli. The apical margin carries a broad band of dusky skin, and is not distinctly dentate. This is certainly a peculiar scale, but my specimens are more or less latinucleate.

Suborder KuRTOIDEA.

KURTIDEE.

The scales, according to Boulenger, are minute and rudimentary.

Suborder LABYRINTHICI.

ANABANTIDE. Climbing perches.

I have scales of Anabas scandens, from Lake Buhi, Philippine Islands, and A. munii from Sharb-elAish, Egypt; the latter from the British Museum. The characters of the Climbing perch, A. scandens,
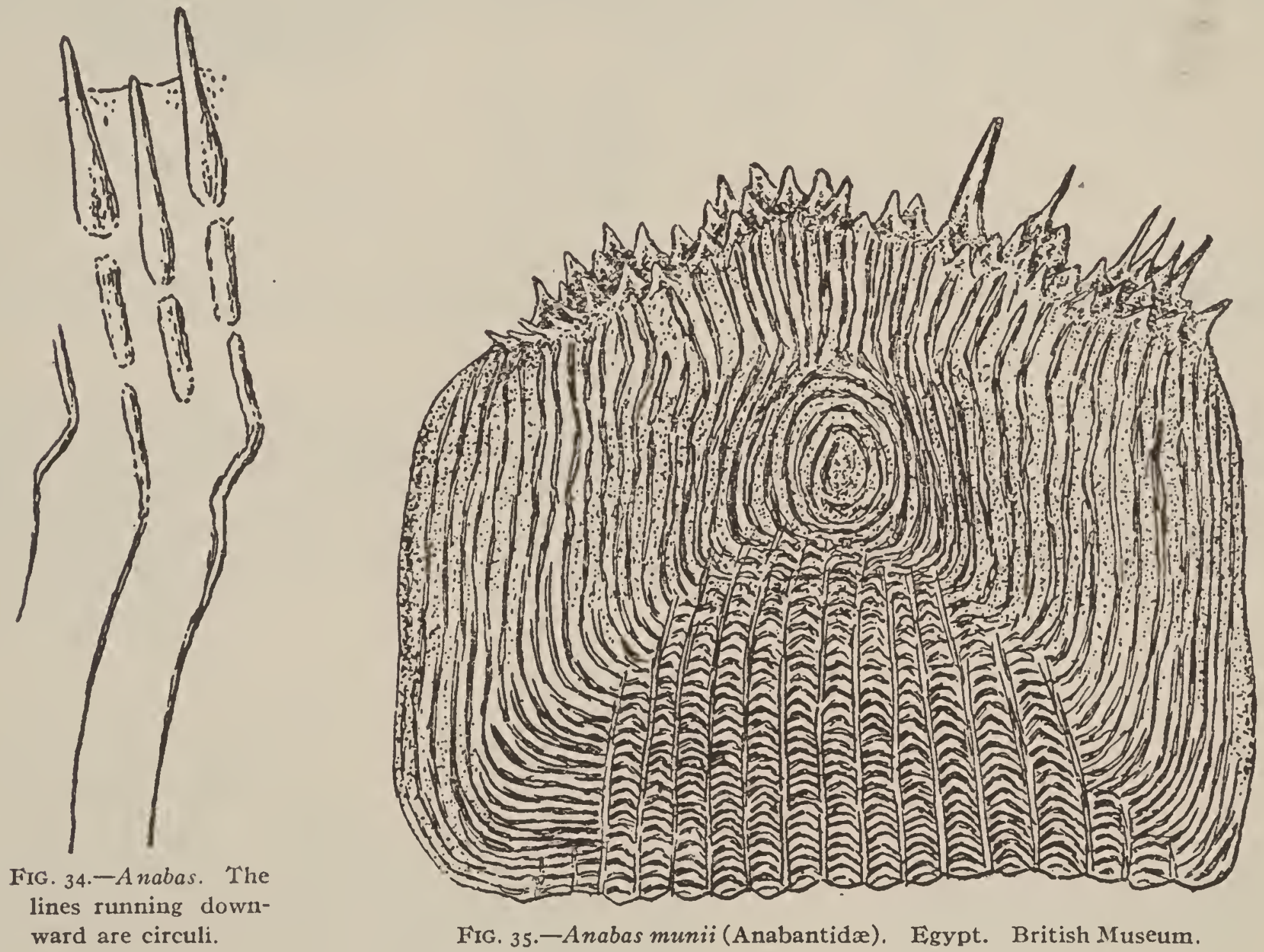

Fic. 35.-Anabas munii (Anabantidæ). Egypt. British Museum.

are given in the table of acanthopterygian scales above; $A$. munii scarcely differs. It is characteristic of A nabas that the basal circuli are dense, the lateral ones rather widely spaced, and those at the sides of the apical field strong and very far apart. The ctenoid patch is decidedly different from that of the percoids, and apparently less specialized. In $A$. munii the apical spines are broadened at base, and are singularly like those of Aphoristia pigra. Boulenger says the Anabantidæ are closely related to the Ophiocephalidæ, in which the scales are cycloid. Goodrich places them in a "subtribe" with the Osphromenidæ. The Anabantidæ apparently can not be derived from the percoids; they represent an early branch from the acanthopterygian stem.

\section{Suborder Hor.conotr. Surf-fishes.}

\section{EMBIOTOCIDA. Surf-fishes. (Pl. XXXvin, fig. $37,3^{8}$.)}

The material studied was all collected by the Albatross, as follows: Zalembius rosaceus (Jordan \& Gilbert), above Santa Barbara Channel; Amphisticus argenteus Agassiz, St. Nicholas Island; Phanerodon furcatus (Girard), San Diego, Cal.; Damalichthys argyrosomus (Girard), Seattle, Wash. The scales are 
similar, all purely cycloid, with the acanthopterygian type of basal radii. They probably represent a cycloid derivative from the ctenoid series, but they certainly can not be derived from the gerrid type I have examined. The nucleus is central or slightly above, and the basal radii are spread out fan-wise. The basal radii are about I $_{5-19}$ in Phanerodon, II-I3 in Damalichthys, 9-10 in Zalembius, 7-Io in Amphisticus. The lateral circuli are angulate in Amphisticus and obtusely bent in Zalembius; in the large ( $8 \mathrm{~mm}$. diam.) scales of Phanerodon the bending of the lateral circuli is evident near the middle, but becomes evanescent toward the periphery. The apical and basal circuli in Phanerodon are very fine and dense.

On comparing these scales with those of the Pœciliidæ, which appeat to be primitively cycloid, it is not at first evident that there is any characteristic difference. The Pœciliids do not show the bending or angulation of the lateral circuli, and their system of basal radii is less regular and fan-like. The general facies is distinctly different, yet it is difficult to point out good diagnostic characters capable of being expressed in words. The atherinid scale, as one would expect, ranks rather with the pociliid than the embiotocid.

Labrid and scarid scales, although cycloid, are entirely different from all these. Jordan places the Embiotocidx in a separate suborder, Holconoti, remarking that "it contains fishes percoid in appearance, with much in common with the Gerridæand Sparidæ, but with certain striking characteristics not possessed by any perch or bass. * * The lower pharyngeals are solidly united, as in the Labridæ, a group which these fishes resemble in scarcely any other respects."

It seems just possible that the Embiotocidæ, although not close to the Labridæ, may agree with them in having had (as I certainly must suppose of Labridæ) no ctenoid ancestors. In this case they would apparently be distant relatives of the scombroid and atherinoid series. We have, however, in the Cichlidæ a scale development similar to that of the Embiotocidæ, and certainly from ctenoid ancestors. (Compare the scale of Tilapia, figured in Smithsonian Miscellaneous Collections, volume 56, no. I.)

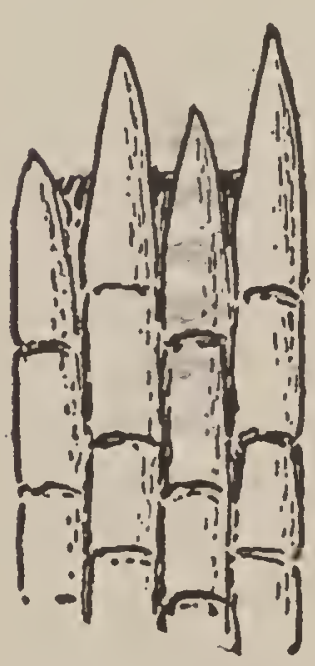

FIG.37.-Abudefduf saxatilis (Pomacentridx). Ctenoid structures. Bureau of Fisheries.

\section{Suborder CHROMides}

Here we return to the normal percoid type of scale.

POMACENTRIDE. Coral-fishes.

I have examined the cockeye pilot, Eupomacentrus leucostictus (Muller \& Trochel), from Key West, Fla. (W. C. Kendall), and Abudefduf saxatilis (Linnæus), from Socorro Island (Albatross). The scales look like those of the Sparidæ. They are broader than long, those of Eupomacentrus being extremely broad (long. 3, lat. nearly $5 \mathrm{~mm}$.). The basal radii are about 9 to $\mathrm{Ix}$. In both genera the lateral circuli are slightly oblique. This is a case in which the fishes have developed very marked structural characters, without any material evolution in the scales.

\section{CICHLIDE. Cichlids. (P1. XxxIX, fig. 39, 40, 4I.)}

The cichlid scales much resemble those of the pomacentrids, but the lateral circuli are not oblique, and the submarginal apical elements, instead of being truncate, are obtusely pointed and spinelike, herein approaching the condition of the Anabantidæ. It thus becomes possible to get an idea of the evolution of the complicated and specialized ctenoid patch of the percoids, the stages being represented more or less accurately by the Macruridæ, Anabantidæ, Cichlidæ, and Pomacentridæ, although, of course, this arrangement does not correctly represent the evolution of these particular families. It is also worthy of note that Tilapia nilotica (figured in Smith. Misc. Coll., 56, pl. I, fig. 3) has exactly the anabantid type of circuli, with widely spaced coarse ones at the sides of the apical area. The middle of the apical area in $T$. nilotica is covered 
with coarse granules or tubercles, and the scale appears to be strictly cycloid, but with a microscope it is possible to see minute short teeth all along the apical margin.

I give a key for the separation of the cichlid scales now before me:

Apical margin apparently cycloid, the rudimentary teeth microscopical......... Tilapia nilotica Apical margin evidently ctenoid, the ctenoid patch highly developed, the elements imbricated... I

r. Scales not greatly broader than long; elements of ctenoid area very distinct, relatively large, the submarginal ones broadened basally; basal radii 8 to ro (Lake Hyanuary, Brazil, M. C. Z., 5285; Cichla monoculus Agassiz, det. Steindachner).

Chætobranchopsis ocellaris Bloch \& Schneider

Scales much broader than long; elements of ctenoid area smaller.......................

2. Nucleus much less than a third of total length from apex; scales large, about $8 \mathrm{~mm}$. long and rot broad; basal radii about II; basal margin very deeply crenate (Coary, Brazil, M. C. Z.,

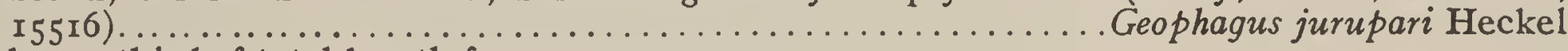

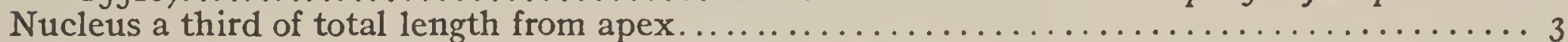

3. Basal radii about II or I2 (Rio Novo, Brazil, M. C. Z., I5739).

Basal radii about I6 (Lake Hyanuary, Brazil, M. C. Z., Geophagus brasiliensis Quoy \& Gaimard

On the label of the $G$. brasiliensis is a manuscript generic name proposed by Steindachner for this fish, but not published. As the fish was named by Steindachner, it is perhaps really G. steindachneri Eigenmann \& Hildebrandt, which Steindachner confused with brasiliensis.

The present distribution of the Cichlidæ is much like that of the Characinidæ, except that they occur in India and Madagascar, where the characinids are absent. Their northern origin is strongly suggested by the occurrence of a genus (Priscacara) in the Eocene of Wyoming. This genus has ctenoid scales of the normal cichlid type, and numerous basal radii, closely placed in the central part of the scale. The character of the ctenoid area confirms the view that the genus is cichlid, not pomacentrid.

\section{Suborder Pharyngognathi. Labroid fishes.}

The Pharyngognathi are variously limited by different authors. Thus Günther (1880) includes the Pomacentridæ, Labridæ, Embiotocidæ, and Chromides. Goodrich (r909) has the same series: Pomacentridæ, Cichlidæ, Embiotocidæ, Labridæ, and Scaridæ. Jordan (1905) includes Labridæ, Odacidæ, Siphonognathidæ, Scaridæ (Scarichthyidæ). Jordan's arrangement is strongly supported by scale characters (I do not know the siphonognathid scale, however); the Günther-Goodrich series includes forms with extremely diverse scales, and is surely unnatural. The scales of the true Pharyngognathi (sens. Jordan) are characterized by the very thin apical margin, wholly without teeth, and especially the presence of apical as well as basal radii. They are thus quite unlike any other acanthopterygian scales known to me, unless they may be associated with the Atherinidæ, in which the shape and general appearance of the scale is quite different. Such atherinids as Chirostoma crvstallinum Jordan \& Snyder (Lake Chapala, Mexico; J. N. Rose) and Menidia notata Mitchill show weak but evident apical radii, in the Chirostoma leading to a strong lobulation of the apical margin. Outside of the acanthopterygian series the pharyngognath scale is strikingly similar to that of the cyprinoids.

\section{LABRIDAE. Wrasses.}

Scales more or less elongate, parallel-sided, having the form seen in the cyprinid genus Labeo (see Biological Bulletin, vol. xx, pl. I, fig. 8). The lateral line canals of Labrichthys are branched anteriorly, as shown by Günther. The regular basal radii in Pimelometopon, Emmeekia, and Coris are in the manner of the acanthopterygians. The species examined are Coris venusta Sauvage, Honolulu, H. I. (Jordan \& Evermann); Emmeekia venusta (Jenkins \& Evermann), Gulf of California (Albatross); slippery dick, Iridio bivittatus Bloch, Key West, Fla.; fathead, Pimelometopon pulcher (Ayres), Santa Barbara Island (Albatross); tautog, Tautoga onitis (Linnæus), Woods Hole, Mass.; and cunner, Tautogolabrus adspersus (Walbaum). 
These may be separated by the following key:

Inner apical circuli usually strengthened, forming wavy longitudinal ridges; apical circuli longitudinal; apical margin broadly thin, with only shadowy indications of radii; basal radii about 8 , and laterobasal (ending above the basal corners) one to four on each side; scales about $32 / 3 \mathrm{~mm}$. long and 2 broad .................... Pimelometopon pulcher (subfamily Harpinæ)

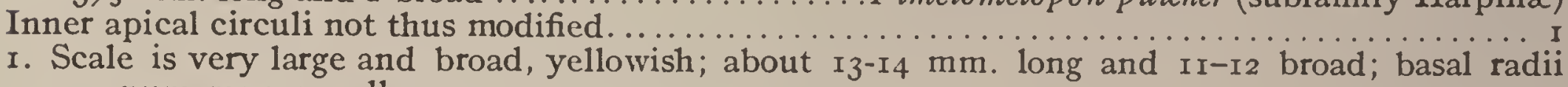

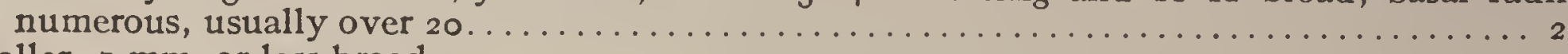

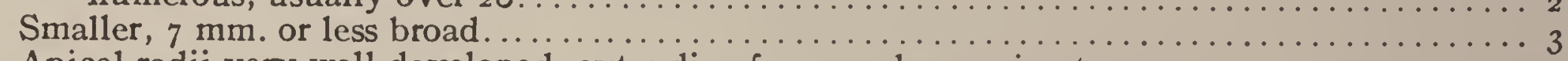
2. Apical radii very well developed, extending from nuclear region to apex.

Apical radii very poorly developed, skin of apical region very thick.

$$
\text { Iridio bivattatus }{ }^{a} \text { (subfamily Julidinæ) }
$$

Tautogolabrus adspersus a (subfamily Labrinæ)

3. Basal radii more than 20 , laterobasal (ending above basal corners) 7 to 10 ; apical radii numerous and close together, though imperfect; lateral circuli very dense; scale very long, about 7

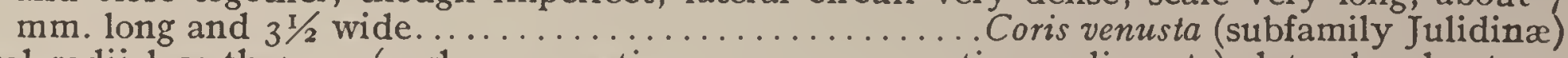
Basal radii less than 20 (perhaps sometimes over 20 , counting rudiments), laterobasal I to 7 ;
scale not twice as long as wide $b \ldots \ldots \ldots \ldots \ldots \ldots \ldots \ldots \ldots \ldots \ldots \ldots \ldots \ldots \ldots \ldots \ldots \ldots$

4. Apical radii distinct; scale about $9 \mathrm{~mm}$. long and 6 broad.

Apical radii indistinct or imperfect; scale about ro $\mathrm{mm}$. long and 6 broad.

Emmeekia venusta (subfamily Julidinæ) Tautoga onitis (subfamily Labrinæ)

ODACIDA.

The scaie of Odax lineatus, as figured by Günther, is entirely of the labrid type, and is very like that of Coris.

SCARIDF. Parrot-fishes. (Pl. xxxix, fig. 44.)

Scarus croicensis (Bloch) has scales differing from those of the Labridæ in being short and broad, shield-shaped, about $6 \mathrm{~mm}$. long and a little less in width. Lateral and basal circuli excessively fine; basal margin broadly truncate, lobed in middle, but not in the least crenulate; basal and apical radii very well marked, but only the inner ones reaching the nucleus; there are about 16 apical and the same number basal and laterobasal; apical region papillose, but the apical margin very broadly thin and subhyaline. A very cyprinid-looking scale.

\section{Suborder Squamipinnes. Scaly-fins.}

\section{EPHIPPIDA. Spadefishes.}

Günther has figured the scale of Ephippus or Scatophagus multifasciatus. It is represented as strongly ctenoid, with several rows of teeth; the basal radii are feebly indicated by a few broad depressions.

\section{CHETODONTIDE. Butterfly-fishes.}

I have Chøtodon ulietensis Cuvier \& Valenciennes from Apia, Samoa; C. bricei Smith, from Katama Bay; and Pomacanthus arcuatus (Linnæus). The characteristic ctenoid sculpture of these genera is shown in figures $3^{8}$ and 39 . The marginal teeth in Chatodon are very sharp, and both the teeth and the truncate submarginal elements have a specialized triangular area, shaped like a thorn, superimposed, as it were, upon their surface. All this is exactly the same in the Atlantic $C$. bricei as in the Pacific C. ulietensis, notwithstanding the great geographical separation.

In $C$. ulietensis the ctenoid area is very large and well-formed in all its details; the basal radii are about I 7 ; laterobasal angles obtuse; lateral circuli very slightly oblique. (P1. xxxix, fig. 45.)

In the Pomacanthus the ctenoid region is much modified, the broad though sharp apical teeth each having a very strong rib which extends more than a millimeter basad, the successive ctenoid elements

a Superficially these scales look exactly alike.

b In young Tautoga scales, $5 \mathrm{~mm}$. long, the length is twice the width. 
having perhaps coalesced. The basal radii are weak, about 3 to 7 , and the excessively dense lateral circuli are not at all oblique.

The fishes represent two subfamilies, Chætodontinæ and Pomacanthinæ.

Suborder Scl,ERODERmi. Hardskin fishes.

BALISTIDE. Trigger-fishes.

The leather jacket, Balistes carolinensis Gmelin, has peculiar thickened, extremely broad scales, about $3 \mathrm{~T} / 4 \mathrm{~mm}$. long and 7 broad, the apical half covered with large tubercles, which appear to be homologous with the spines of the Macruridæ. These tubercles or spines are curiously suggestive of those on

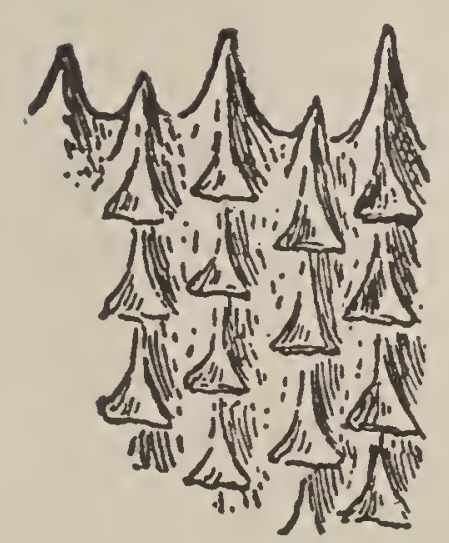

FIG. 38.-Chatodon ulieten sis (Chætodontidæ). Ctenoid structures. Bureau of Fisheries.

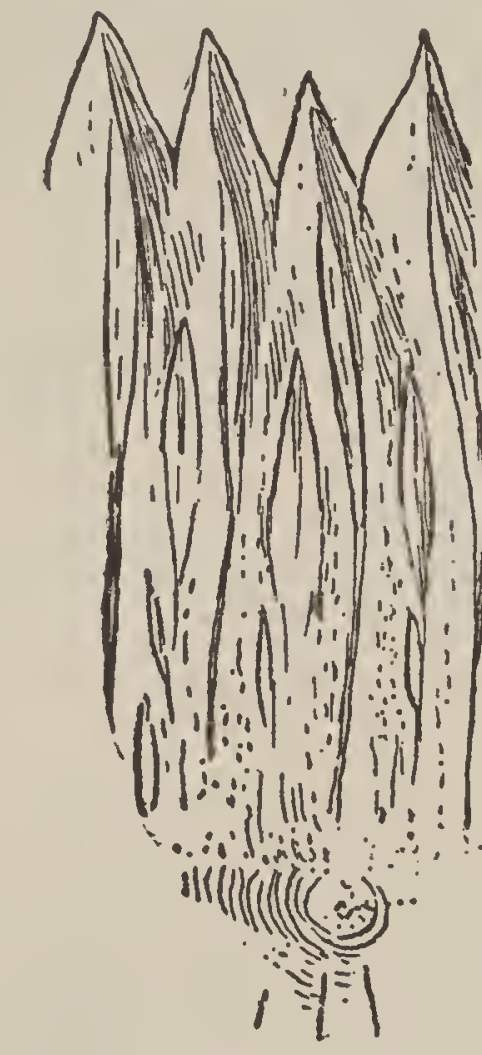

Fig.39-Pomacanthusarcuatus (Chætodontidæ). Ctenoid structures. Bureau of Fisheries.

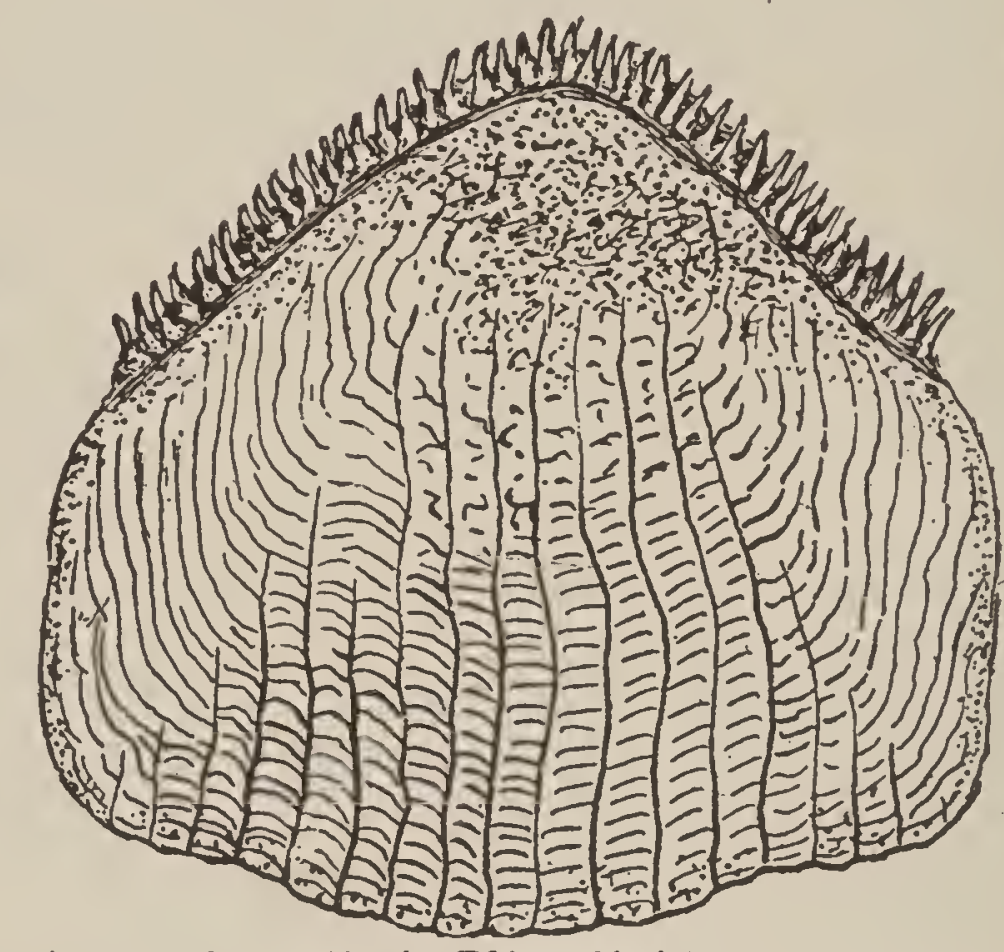

Fig. 40.-Ctenogobius (or Rhinogobius) hadropterus. Japan. Stanford University.

the scutes of Acipenser. Those along the basad margin of the tuberculate area are arranged in a regular row, which is angled in the middle, the very broad angle looking apicad. A quite different looking Balistes scale, with six large spines, is figured in the Cambridge Natural History, Fishes, page I9I.

\section{MONACANTHIDE. Filefishes.}

A scale of Monacanthus, of the same general type as that of Balistes, is figured in the Cambridge Natural History, on the page just cited. The large spines are arranged much as in the macrurids (e. g., Macrurus carminifer Garman).

I have material of the orange filefish, Ceratacanthus schopfii (Walbaum), from near Woods Hole, Mass., kindly given to me by Dr. E. Linton. The skin contains many minute spots of black pigment, and in places a fine dark blue pigment, which does not turn red in acids. The scales are shaped nearly as in Monacanthus and the exposed area of each has numerous large spine-like structures, one of which is much larger than the others. The concealed part of the scale is striate, with the appearance under the microscope of tree trunks closely packed, branching more or less distally. 


\section{Suborder GoBIOIDEA.}

\section{GOBIIDA. Gobies.}

Jordan remarks that the Gobiidæ have no near relations among the spiny-rayed fishes. Günther has figured the scale of Gobius, and I am indebted to Dr. Jordan for material of the Japanese Mapo fuscus (from Tanegashima), Ctenogobius virgatulus (from Shiogama) and C. hadropterus (from Tanegashima). These fishes have basal radii as in the acanthopterygians, but the nucleus is at the very apex of the scale, and the marginal teeth form a single apical row as in the Aphredoderidæ; exactly, also, as in the ctenoid African Characinidæ. In the ctenoid African characinids the basal radii are not developed, or rather are represented by mere folds; in Aphredoderus they are very distinct, but not numerous; in the Gobiidæ they are very numerous and close together. In the gobiids the relatively short (though very strongly developed) apical teeth are more like those of the ctenoid characinids than those of Aphredoderus, and the characinid Distichodus, with its more or less pointed or angled apical margin, suggests the very strong angulation of that margin seen in

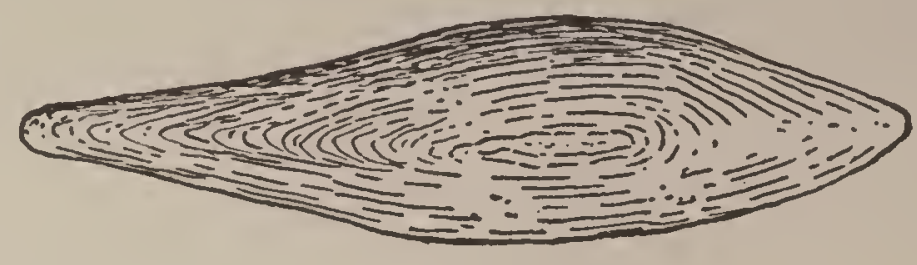

FIG. 4I.-Leptecheneis naucrates (Echeneidæ). Apical end to the right. Bureau of Fisheries.

the Gobiidæ. Percopsis has the apical nucleus and angled margin of the gobiids, but the marginal teeth are less developed, and the basal radii are absent.

The gobiid scales before me may be separated as follows:

Lateral margin (from apicolateral to basolateral angles) somewhat larger than apical margin of one side; some radii lateral (entering margin above basolateral corner); radii about 22. Mapo fuscus

Lateral margin shorter or not longer than apical margin of one side; no radii lateral ............ I I. Lateral circuli quite dense; radii about 30 , some imperfect.

Lateral circuli not dense; radii about $\mathrm{I}_{4}$, some imperfect.

Ctenogobius virgatulus Jordan \& Snyder Ctenogobius hadropterus Jordan \& Snyder

Latinucleate scales are common and are of course much modified, though they retain the characteristic margin.

\section{Suborder Discocephali.}

\section{ECHENEIDA: Remoras.}

I had examined the shark sucker, Lepiecheneis naucrates (Linnæus), collected at Woods Hole, Mass., and concluded that there were no scales. Dr. E. Linton, who was working on the parasites of this fish, suggested that scales might be found in the skin, and so it proved. The completely embedded scales have an elongate-lanceolate form, pointed or obtuse at the ends, length about $2 \mathrm{t} / 2 \mathrm{~mm}$. The sculpture consists only of rather widely spaced concentric circuli. No other similar scale is known to me, though in the matter of sculpture (though not at all in form) the scales substantially agree with those of Lota. 


\section{Suborder SCLEROPAREI.}

SCORPANIDAE. Scorpion fishes.

In this family the scales may be fully ctenoid, or may entirely lose the teeth.

\section{Subfamily SEBASTINAE.}

Sebastes Cuvier, rosefish. S. marinus (Linnæus) from Woods Hole (V. N. Edwards), has small oblong scales with five basal radii, very widely spaced circuli, and three or four very large and stout apical spines (fig. 74). The apical circuli are angled in the middle.

Sebastodes Gill. Mr. A. R. Moore very kindly sent a number of species of Sebastodes from California, showing that the genus has rather large scales, very strongly ctenoid, with very numerous, strong and crowded apical teeth, and the ctenoid patch with several rows of distinct elements (fig. 76). The basal radii are fairly numerous.
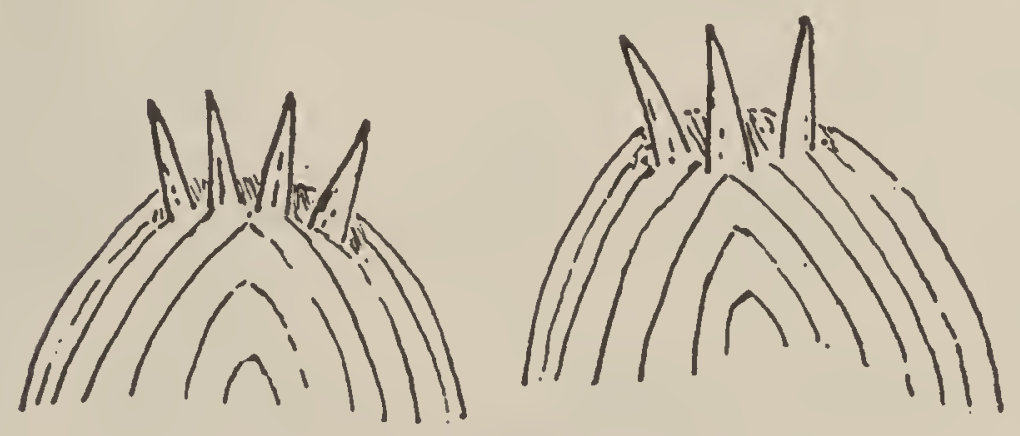

FIG. 42.-Sebastes marinus (Scorpænidæ). Apical structures. Bureau of Fisheries.

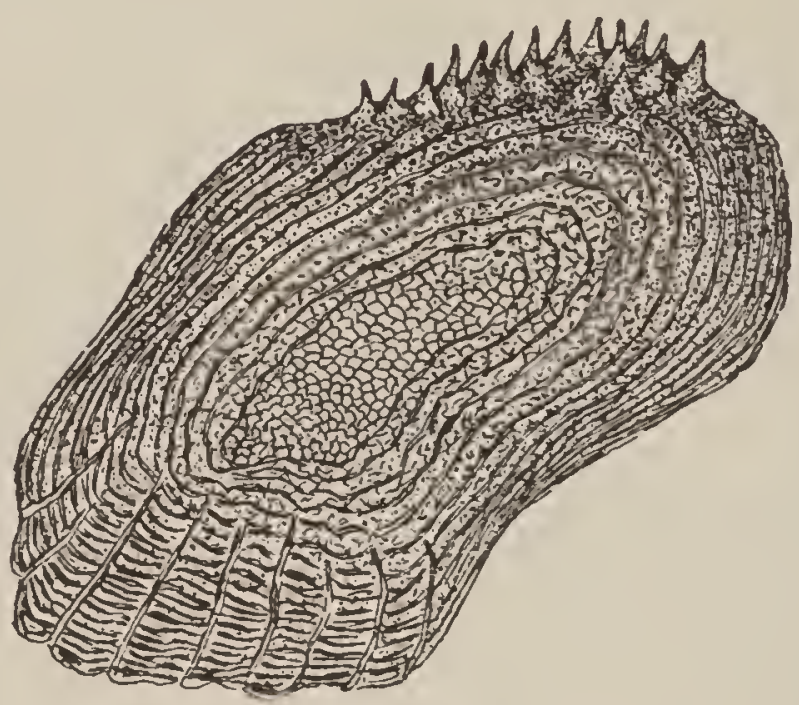

FiG. 43. -Sebastodes paucispinis (Scorpænidæ) California.

Mr. Moore sent S. paucispinis (Ayres), S. flavidus (Ayres), S. mystinus Jordan \& Gilbert, S. ruberrimus Cramer, S. constellatus (Jordan \& Gilbert), S. rosaceus (Girard), S. carnatus (Jordan \& Gilbert), and $S$. nebulosus (Ayres), and although the scales of all these were carefully examined by Miss Evelyn Moore and myself, we could find no satisfactory specific characters.

\section{Subfamily SCORPAENINA}

Scorpæna Linnæus. S. plumieri Bloch, from Katama Bay, has small scales a little over I mm. long, and about I mm. broad, with coarse but dense circuli, and about seven basal radii. The circuli fail in the apical field, and the margin is cycloid, with, however, occasional rudiments of minute teeth.

Helicolenus Goode \& Bean. H. dactylopterus (De la Roche), from off Woods Hole, in gulf weed, has comparatively large scales, oval in form, about $4 \mathrm{~mm}$. long and 3 wide. They are cycloid, and formed much as in Scorpana, but with about ${ }_{3} 3$ basal radii. The apical field is covered with little tubercles, resulting from the breaking up of the apical circuli. The basal circuli are very minutely beaded. Jordan \& Evermann state that this genus has ctenoid scales on the top and sides of the head, which is not true of Scorpana.

So far as the scales go Sebastodes should be in the most primitive of the above genera. 
COTTIDE. Sculpins.

In the fossil Lepidocottus brevis (Agassiz), from the Upper Miocene at Wangen, Baden (E. Penard), the scales are as in the Gobiidæ, with angled apical margin, a single row of marginal teeth, apical nucleus,

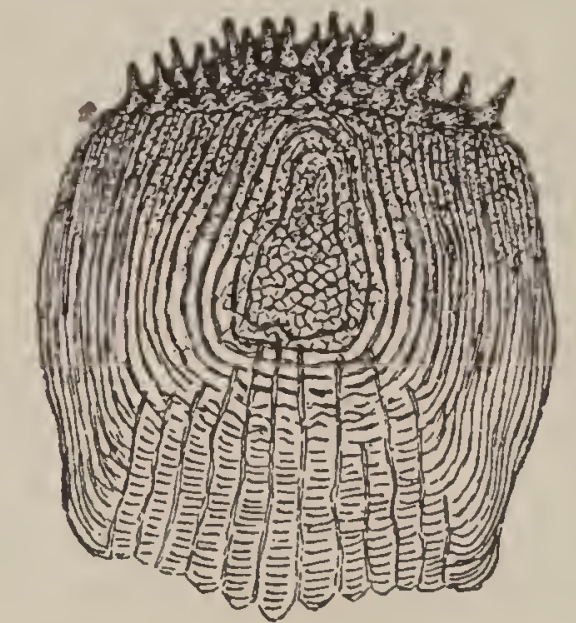

FIG. 44.-Sebastodes paucispinis (Scorpænidæ). California.

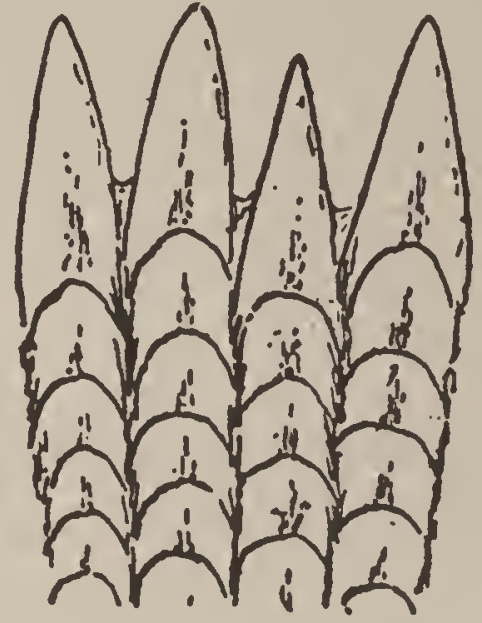

Fig. 45.-Prionotus strigatus ('Triglidæ). A pical structures. Bureau of Fisheries.

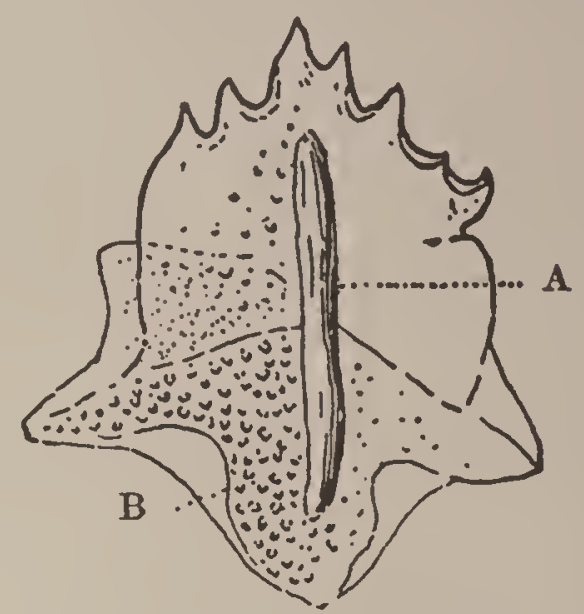

FIG. 46.-Cephalacanthus volitans (Cephalacanthidæ). A, high crest; B, pigment spots. Bureau of Fisheries.

etc. Is it quite certain that this fish really is a cottid? Species of Lepidocottus have actually been described under Gobius.

\section{PLATYCEPHALIDE. Flatheads.}

Günther has figured the scale of Platycephalus cirrhonasus. It is of typically ctenoid character' with about four basal radii, but long and parallel sides, the shape suggesting the labrids.

\section{Suborder CRAniomr. \\ TRIGLIDE. Sea robins.}

Prionotus strigatus (Cuvier \& Valenciennes), the striped sea robin, from Woods Hole, has the scales subquadrate, about $4^{1} / 2 \mathrm{~mm}$. long and 5 broad, typically ctenoid, with the ctenoid patch large; basal radii about seven or eight; lateral circuli parallel with margin. The submarginal apical elements are very short, broader than long.

\section{CEPHALACANTHIDAE. Flying gurnards.}

Cephalacanthus volitans (Linnaeus), the flying gurnard, from Woods Hole, has greatly modified, strongly keeled scales, with the margin toothed. The form is sufficiently shown in the accompanying figure. There is nothing in the scales to suggest affinity between the triglids and cephalacanthids.

\section{Suborder HeTERosomata. Flatfishes.}

I have given an account of the scales of these fishes in Proceedings of the Biological Society of Washington, volume $\mathrm{xxIV}$, pages $209-2 \mathrm{rr}$; it remains now only to present some figures, and a few additional details.

\section{PLEURONECTIDE. Flounders.}

I am indebted to Dr. F. B. Sumner for scales of Platophrys (or Rhomboidichthys) podas, from the Bay of Naples. In my table, in the paper just cited, they run to Platophrys constellatus, from which they scarcely differ. Both have traces of radial lines crossing the lateral circuli, producing a sort of delicate cancellation. The apical teeth in $P$. podas are about 7 or 8 , very stout and strong.

\section{SOLEIDE. Soles.}

Scales of a species of Cynoglossus from Hongkong (M. C. Z., rr329) are large, about 9 mm. long and nearly 6 broad; strongly ctenoid on the upper (pigmented) side of the fish, strictly cycloid below. 
The basal radii are excessively numerous and close together (pl. XL, fig. 52). The ctenoid elements are formed essentially as in the tongue sole, A phoristia pigra, which belongs to the subfamily Cynoglossinæ. A truly remarkable feature, equally developed in the cycloid and ctenoid scales, is found in the basal (interradial) circuli, which as they leave the radii are directed obliquely apicad, and in the middle third of the interradial field are broken up into minute more or less pyriform bodies. In Symphurus (or Aphoristia) piger the beginning of this is seen in the fact that some of the interradial sections of the circuli are bent and V-like: The extreme and unique modification of the basal circuli in Cynoglossus is important, as I think it amounts to a demonstration that Cynoglossus (with cycloid scales on the lower side) is not a primitive member of the Soleidæ and is not connected in any way with the pleuronectids. The general characters of the fish also support this idea.

\section{Suborder JUGULARES. ${ }^{2}$ \\ BLENNIID A. Blennies.}

The rock eel, Pholis gunnellus (Linnæus), from Menemsha Bight, Mass., has extremely minute more or less oval cycloid scales, with the nucleus a little above the middle, very widely spaced circuli,

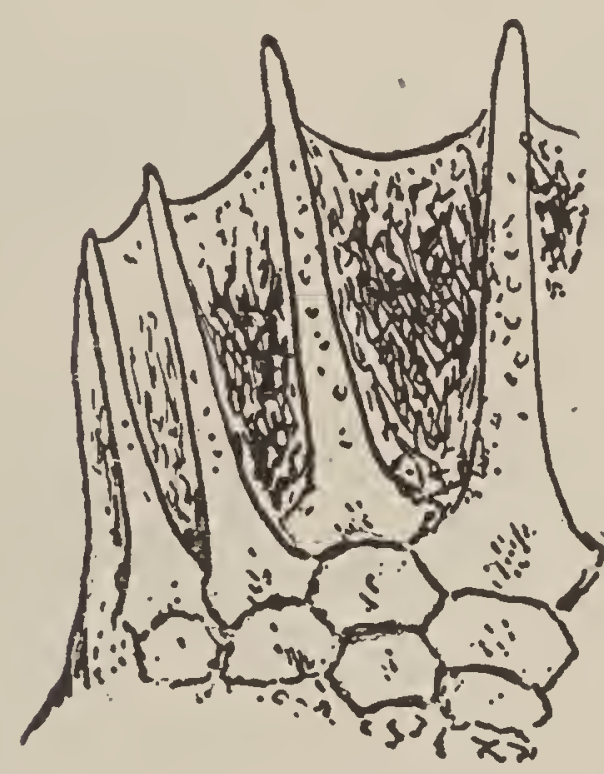

FIG. 47.-Achirus lineatus (Soleidæ). Apical structures. Bureau of Fisheries.

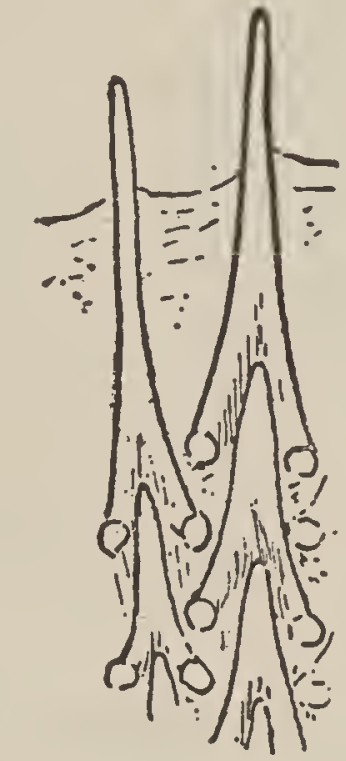

FIG. 48.-A phoristia pigra

(Soleidx). A p i c a 1

structures. Bureau of

Fisheries.

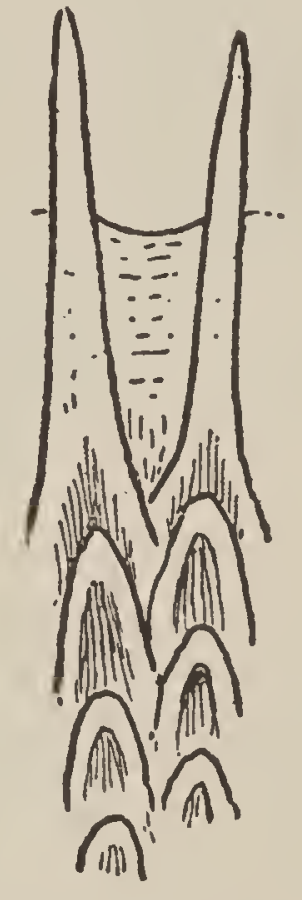

Fig. 49.-Solea solea (Soleidæ).

Apical struc-

tures. Bureau

of Fisheries.

and rather widely separated radii basally and laterally. Ulvaria subbifurcata Storer, taken by Mr. V. N. Edwards from the stomach of a red-breasted merganser (Merganser serrator Linnæus), has similar but longer scales, with the nucleus more apicad, and the 3 to 6 radii all basal. The circuli fail in the apical region.

These are very degenerate scales, which do not suggest any acanthopterygian affinities.

\section{ANARHICHADIDE. Wolf-fishes.}

The wolf-fish, Anarhichas lupus (Linnæus), from Woods Hole, has small nearly circular scales, with central nucleus and radii almost all around, in every way very like those of Pholis.

GADOPSIDE. New Zealand " trouts."

Gadopsis, a fresh-water genus of New Zealand and Australia, has been figured by Günther. The scale is long oval, cycloid, with regular circuli, which are not dense; nucleus a little apicad of middle; six strong radii. All this is very close to the blenniid Ulvaria. The fact that the three families of 
Jugulares, of which the scales are known to me, agree so closely in scale characters must indicate that, degenerate as they are, these scales really represent an ancient type, less modified than other characters of the fishes on which they occur.

\section{Suborder Anacantrini. Gadoid fishes.}

I have discussed this series at some length in Proceedings of the Biological Society of Washington, volume XXIv, pages $2 \mathrm{II}-2 \mathrm{I} 2$. I now offer some figures.

\section{GADIDE. Cods.}

Since the account cited above was printed I have examined scales of the European burbot, Lota lota (Linnæus), from the Danube (M. C. Z. 12366), and the American burbot, L. maculosa (Le Sueur), from
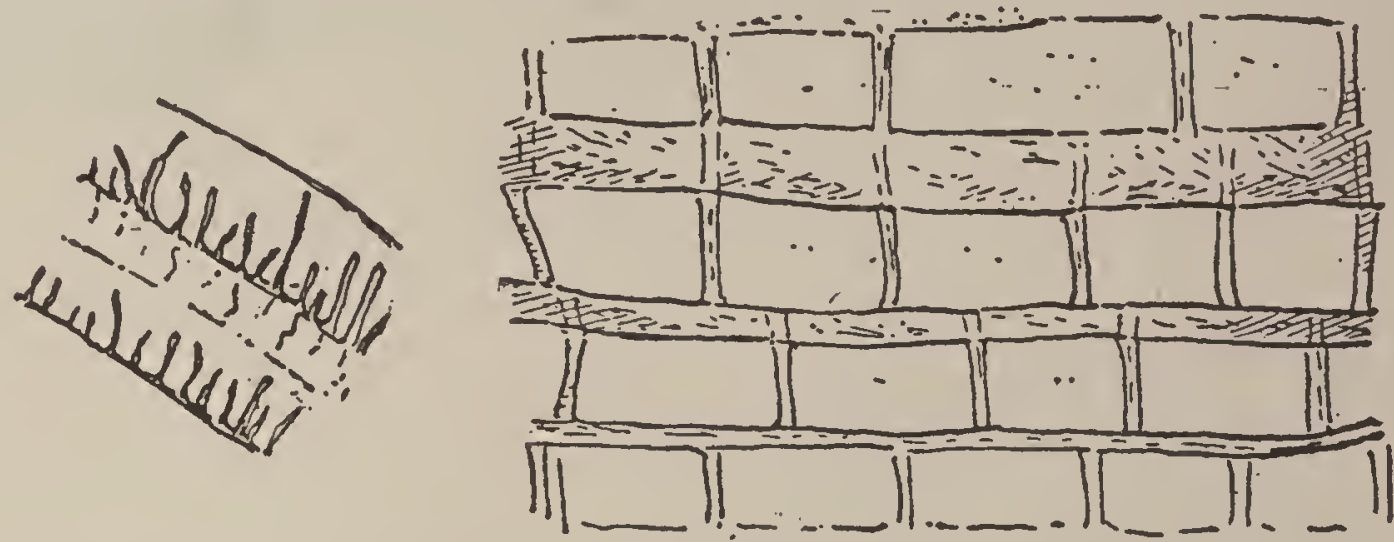

FIG. 50.-Brosmius brosme (Gadidæ). Sculptural details, submarginal region. Bureau of Fisheries. Smaller figure shows sculpture of a latinucleate scale near middle.

Erie, Pa. (Bureau of Fisheries). This genus, typical of the subfamily Lotinæ, has extremely minute circular to suboval scales, with nucleus central or almost; coarse, widely separated circuli, and no radii. It is, however, to be noted that the circuli are crenate or denticulate on the inner margin, a relic of the

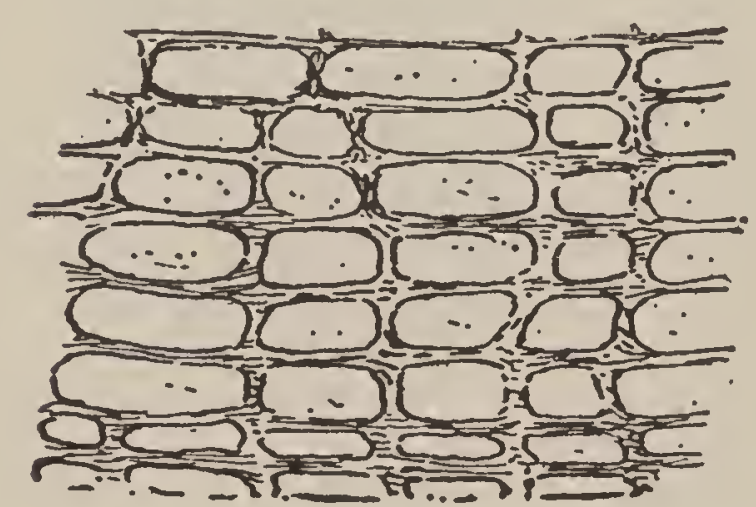

FIG. 51.-Melanogrammus œglepinus (Gadidæ). Details of sculpture, submarginal region. Bureau of Fisheries.

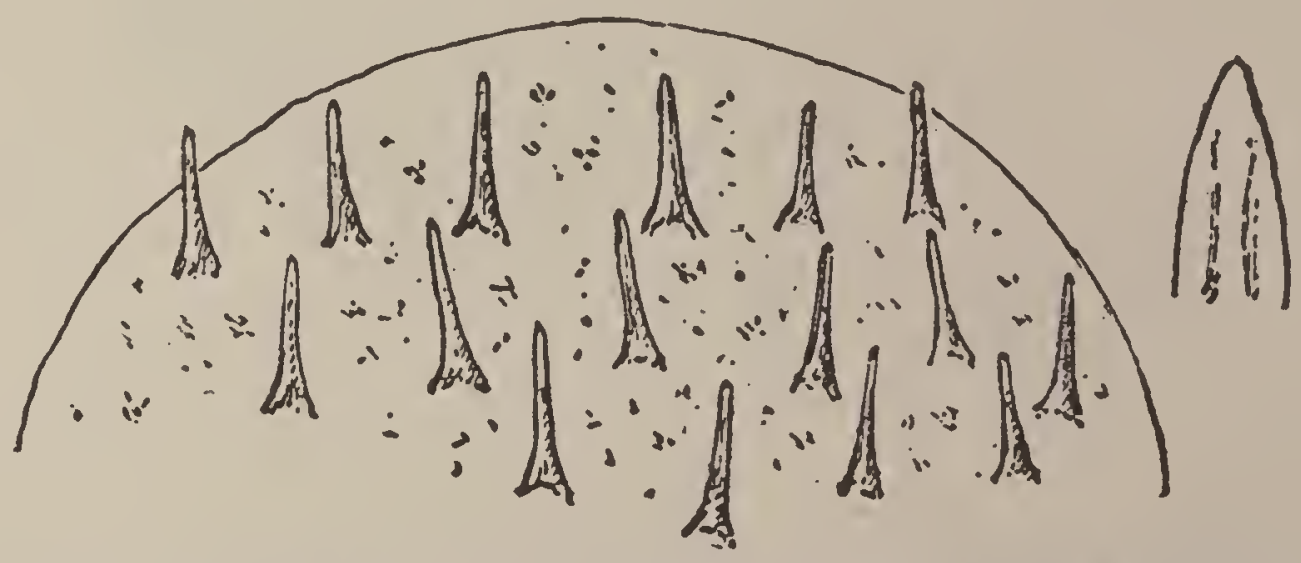

FIG. 52.-Calorhynchus caribbaus, and spine of Macrurus bairdii (Macruridæ). U. S. National Museum.

condition so well marked in Brosmius. I am quite unable to find any difference between the scales of the European and American species.

A scale of Urophysis regius is figured on plate $\mathrm{XL}$ (fig. ${ }^{\mathrm{I}}$.)

MACRURIDE. Grenadiers. (P1. XL, fig. 48.)

Dr. S. Garman (Mem. Mus. Comp. Zool., vol. xxiv) has figured the scales of a number of species of Macrurus, namely $M$. barbiger Garman, M. bulbiceps Garman, M. bucephalus Garman, M. liraticeps 
Garman, M. fragilis Garman, M. tenuicauda Garman, and M. carminifer Garman. M. barbiger has no teeth whatever; $M$. fragilis is represented with a single little tooth. $M$. bulbiceps has very many little spines in the apical field; $M$. carminifer has very large spines. The figure of $M$. tenuicauda looks like a latinucleate scale.

\section{Order PEDICULATI.}

\section{ANTENNARIIDF. Fishing-frogs.}

Dr. Garman, in the work just cited, figures the spiniferous scales of Chaunax coloratus Garman. In the Cambridge Natural History, Fishes, page I9I, is a figure of the scale of Antennarius hispidus.

\section{OGCOCEPHALIDE. Batfishes.}

In the Cambridge Natural History, on the page just cited, is a figure of the spine-bearing scale of Ogcocephalus or Malthe vespertilo (Linnæus). 


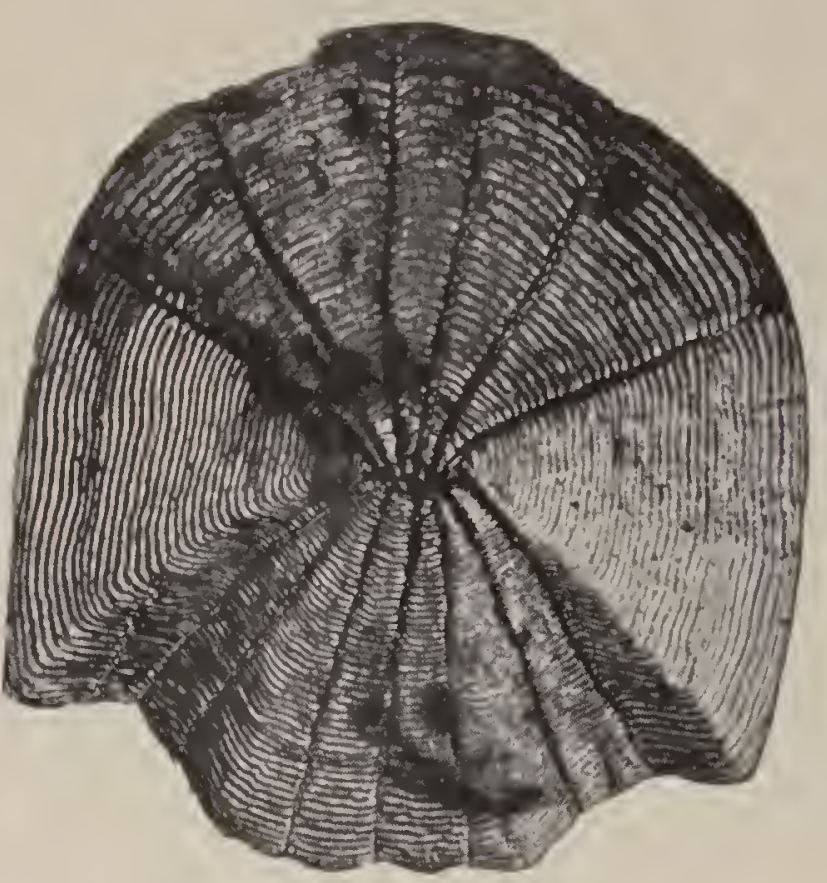

I

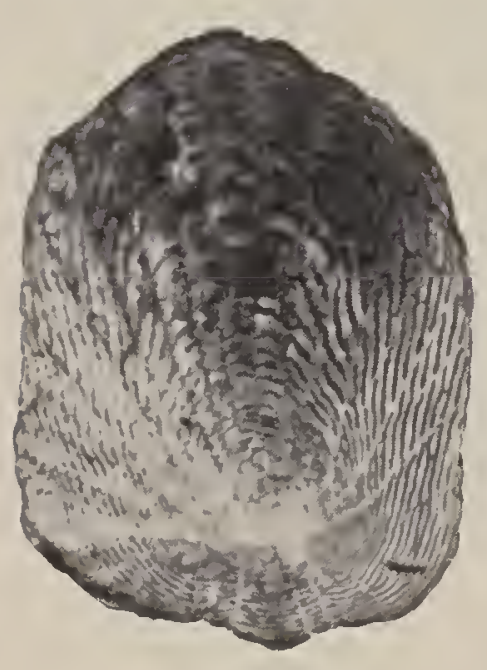

3

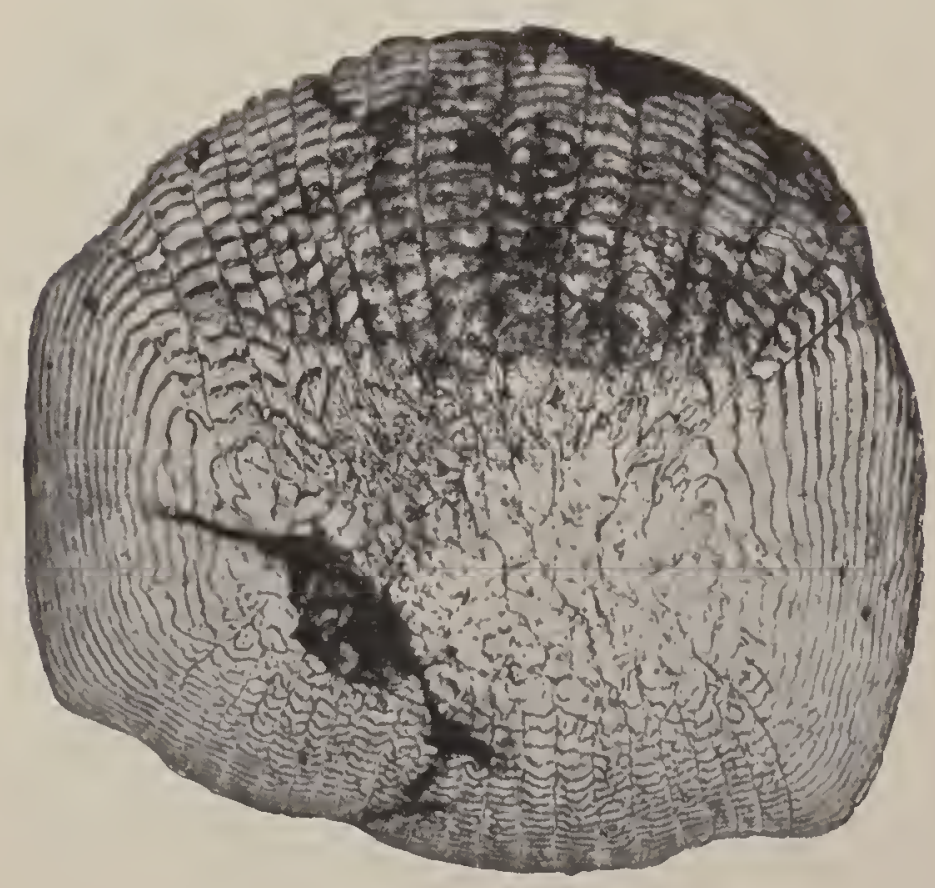

5

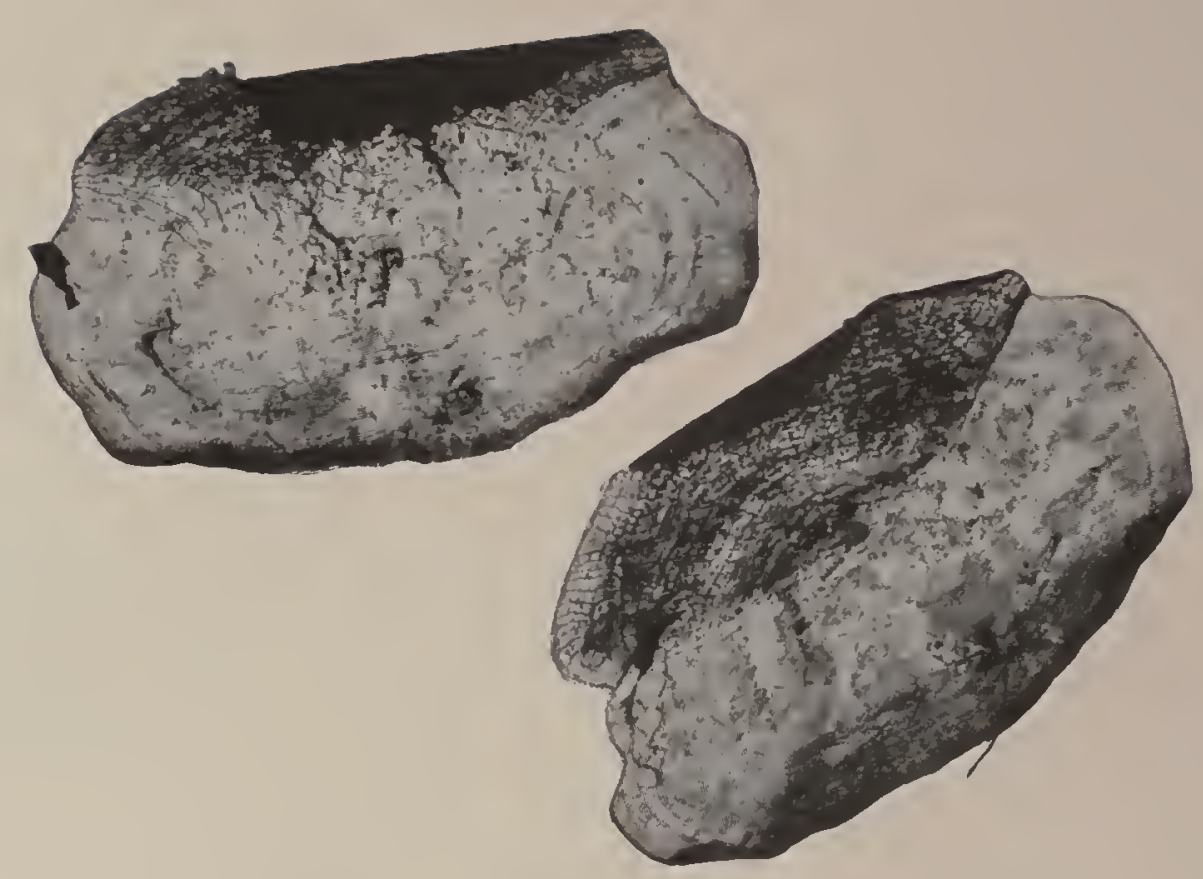

2

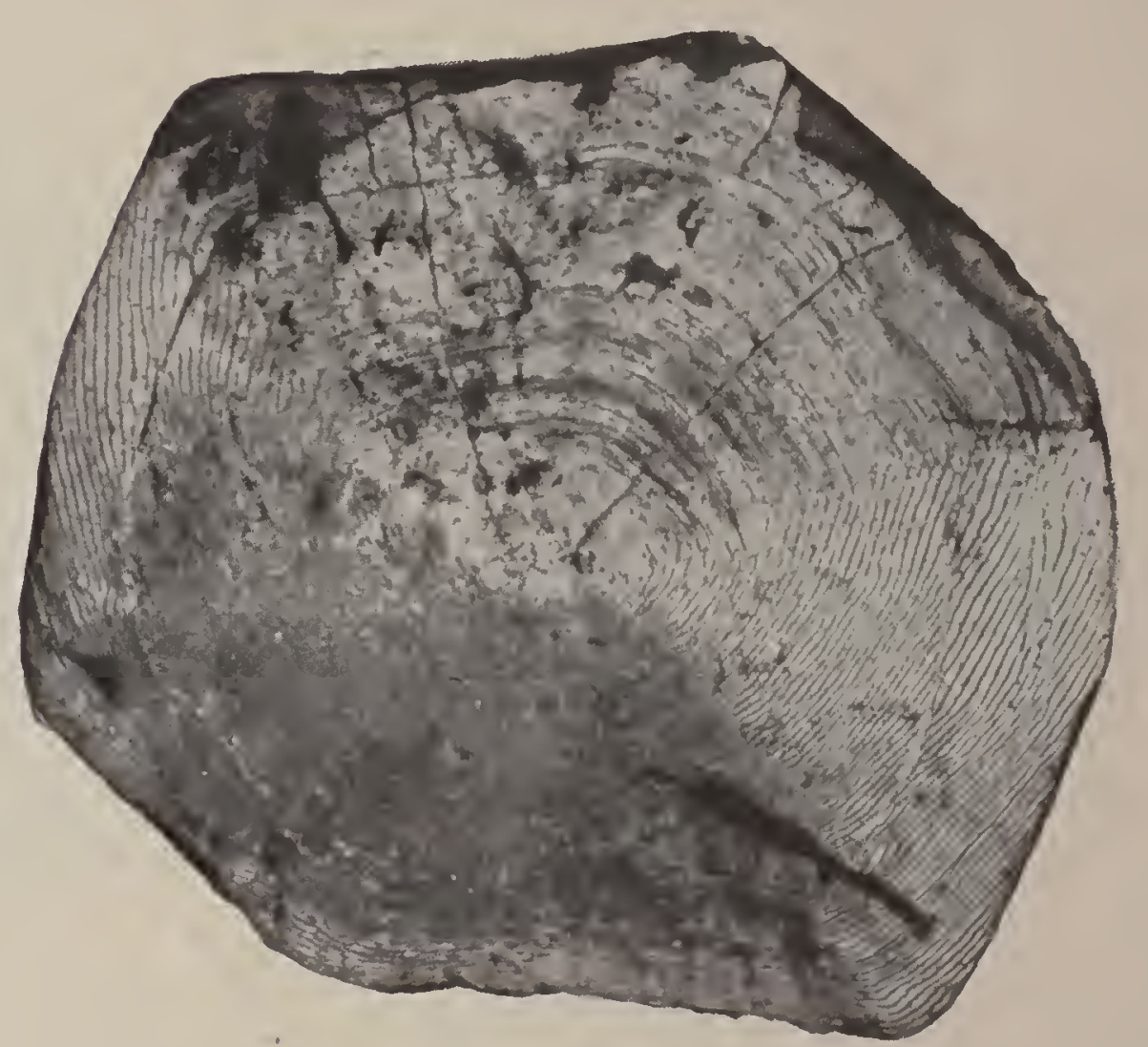

4

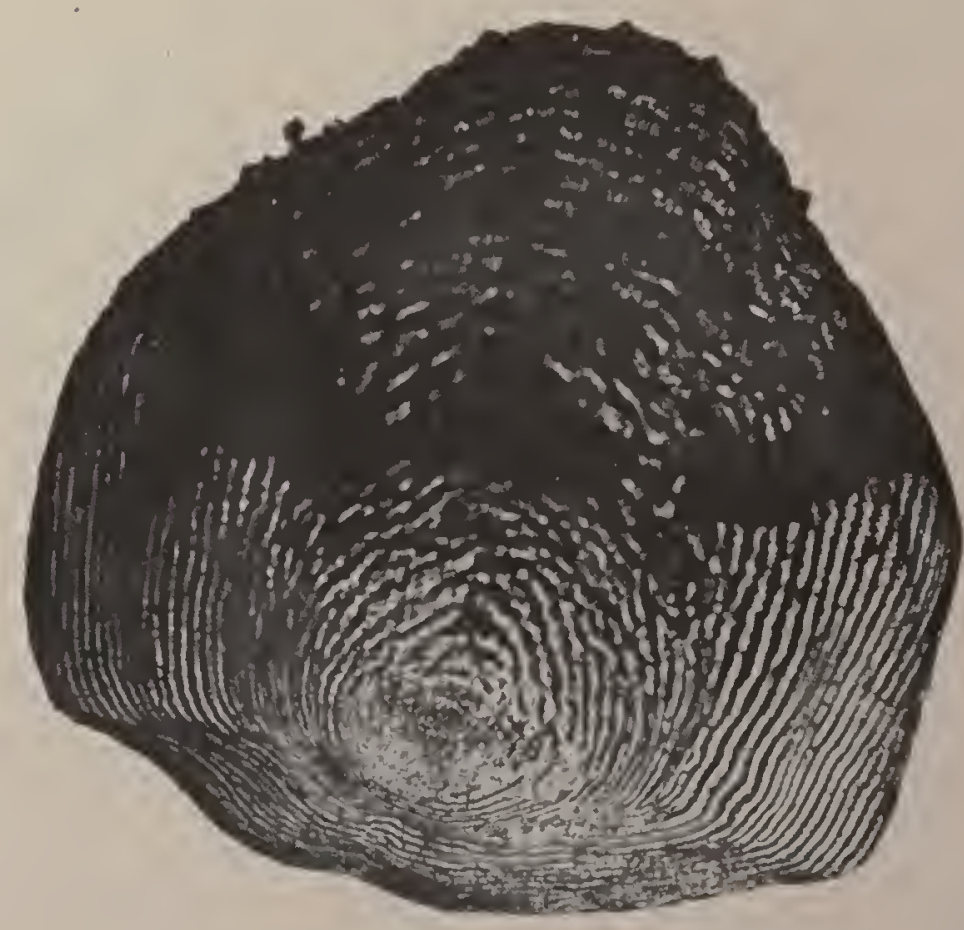

6

FIG. I.-Placopharynx duquesnii. Cherokee, Iowa (S. E. Meek).

FIg, 2,-Acanthorhodeus truianalis. Shanghai (Swinhoe). 'The wavy apical radii are not well shown.

Figr. 3.-Algansea sallaei. Gnanajnato, Mexico (A. I)ngès)

Fig. 4 -Chela paralaubuca. British Musenul,

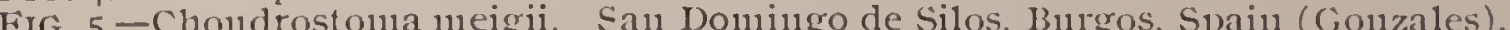

FIG. 6.-Noconnis kentuckiensis. Stone River, 'Tennessee. 


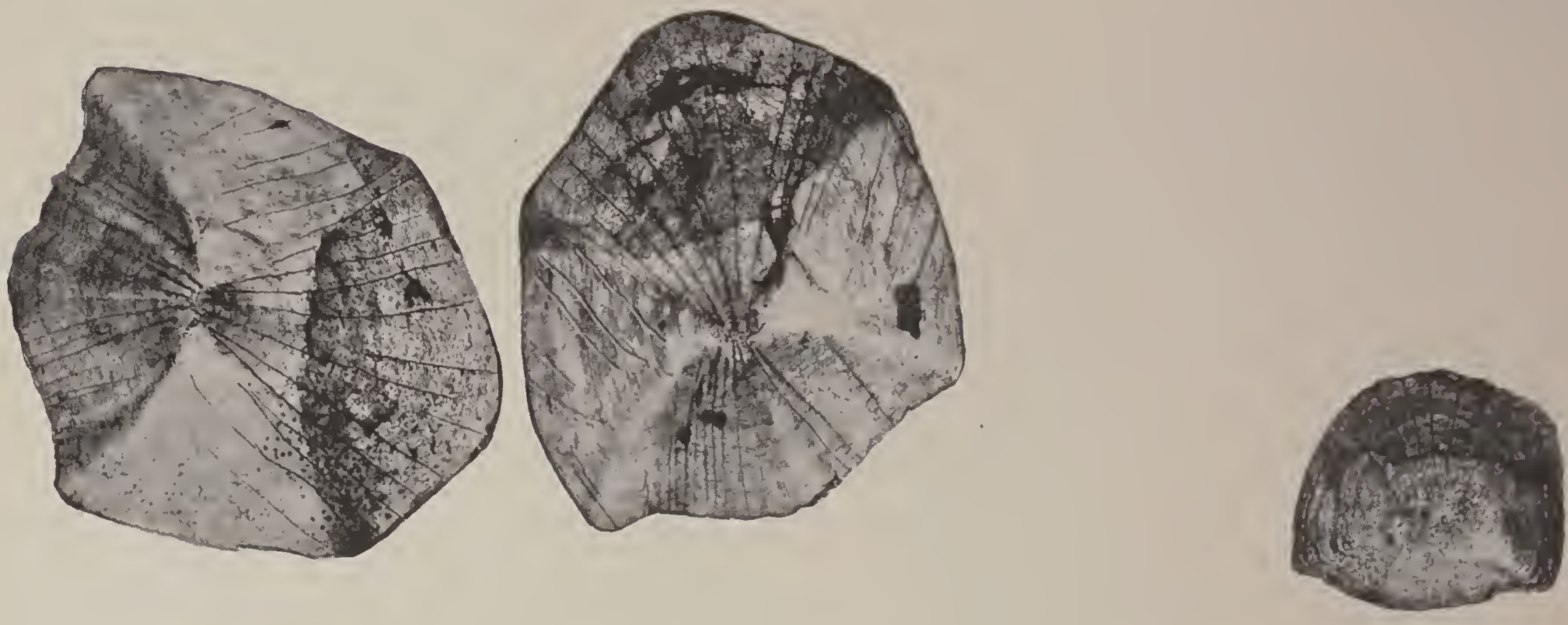

7
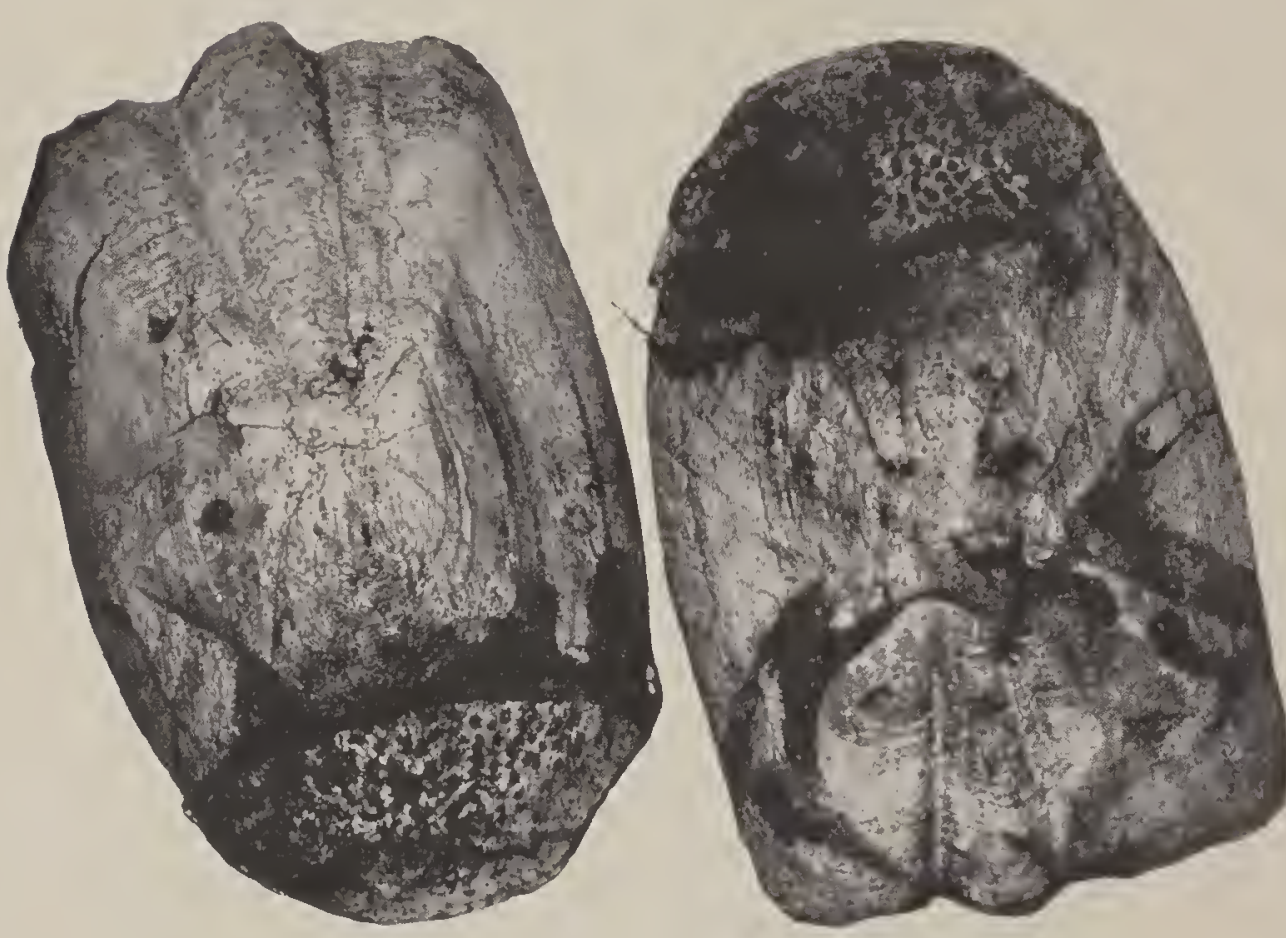

9

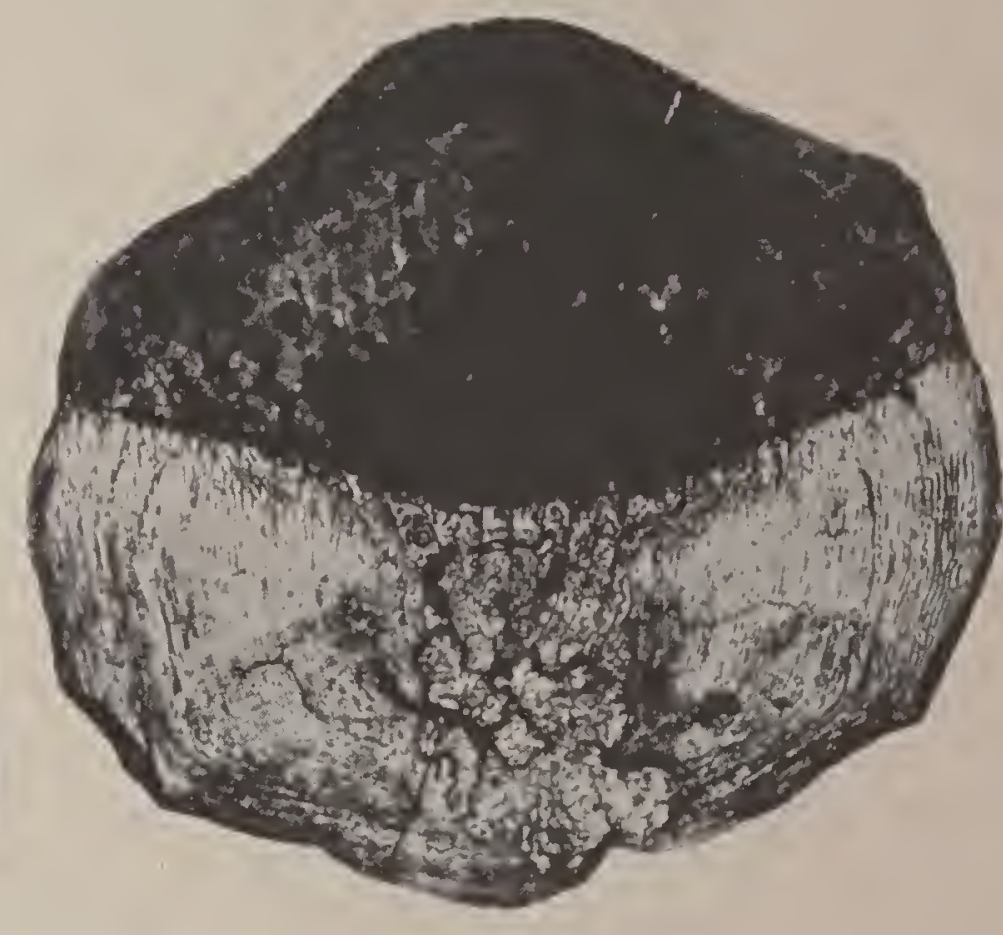

IO

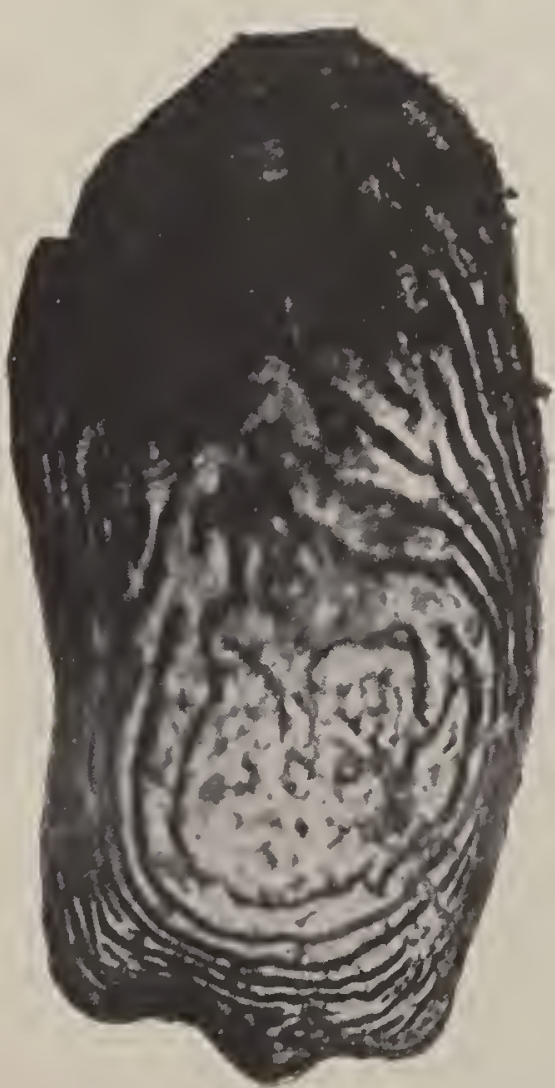

II

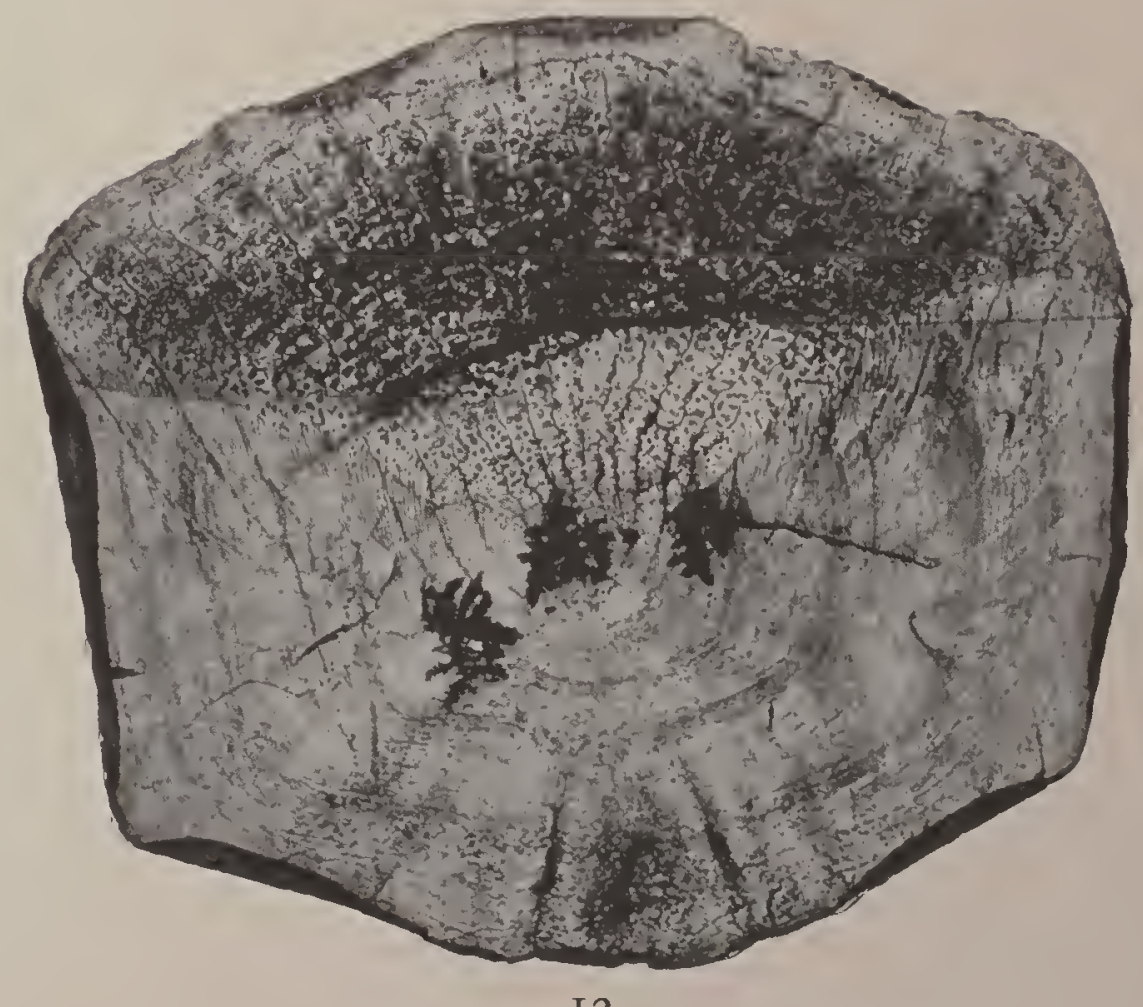

Fitg. 7.-I,uciosoma trinema. Upper Baram River (C. Hose).

Fig. 8. - Notennigonus chrysoleucus. Falmouth, Mass.

Fìg. 9. -Rohinita lineata. Sittang River (L. W. Oates). British Musenm.

Fig. Io-Scaphiodon muscatensis. Muscat, Arahia. British Mrisemn.

Fig. II. - Schizothorax internuedius. Kashigar. Mritish Musemin.

Fig, I'z, - Semiplotus macclellandi. Assan (F. Day). British Museum. 

Buli. U. S. B. F., I9I2.

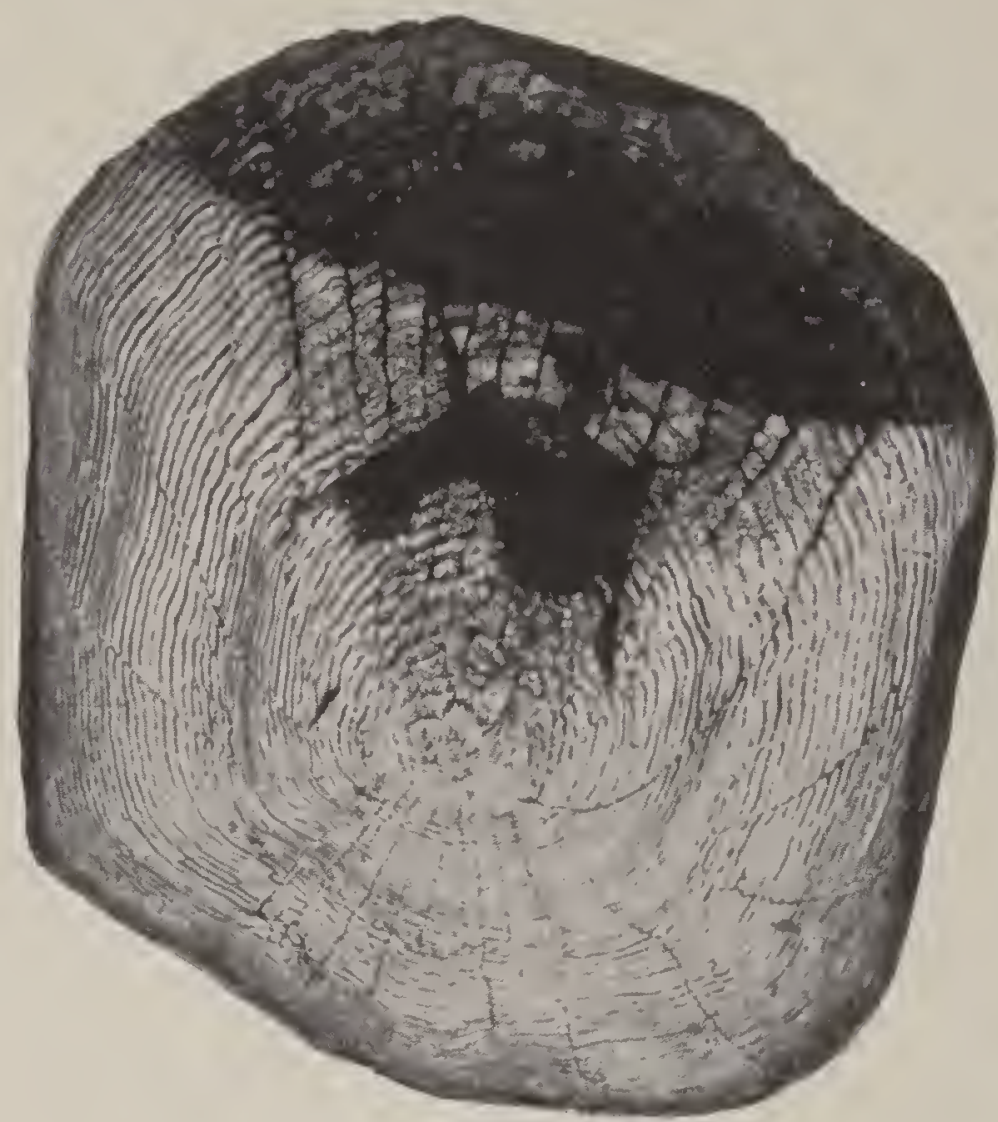

I 3

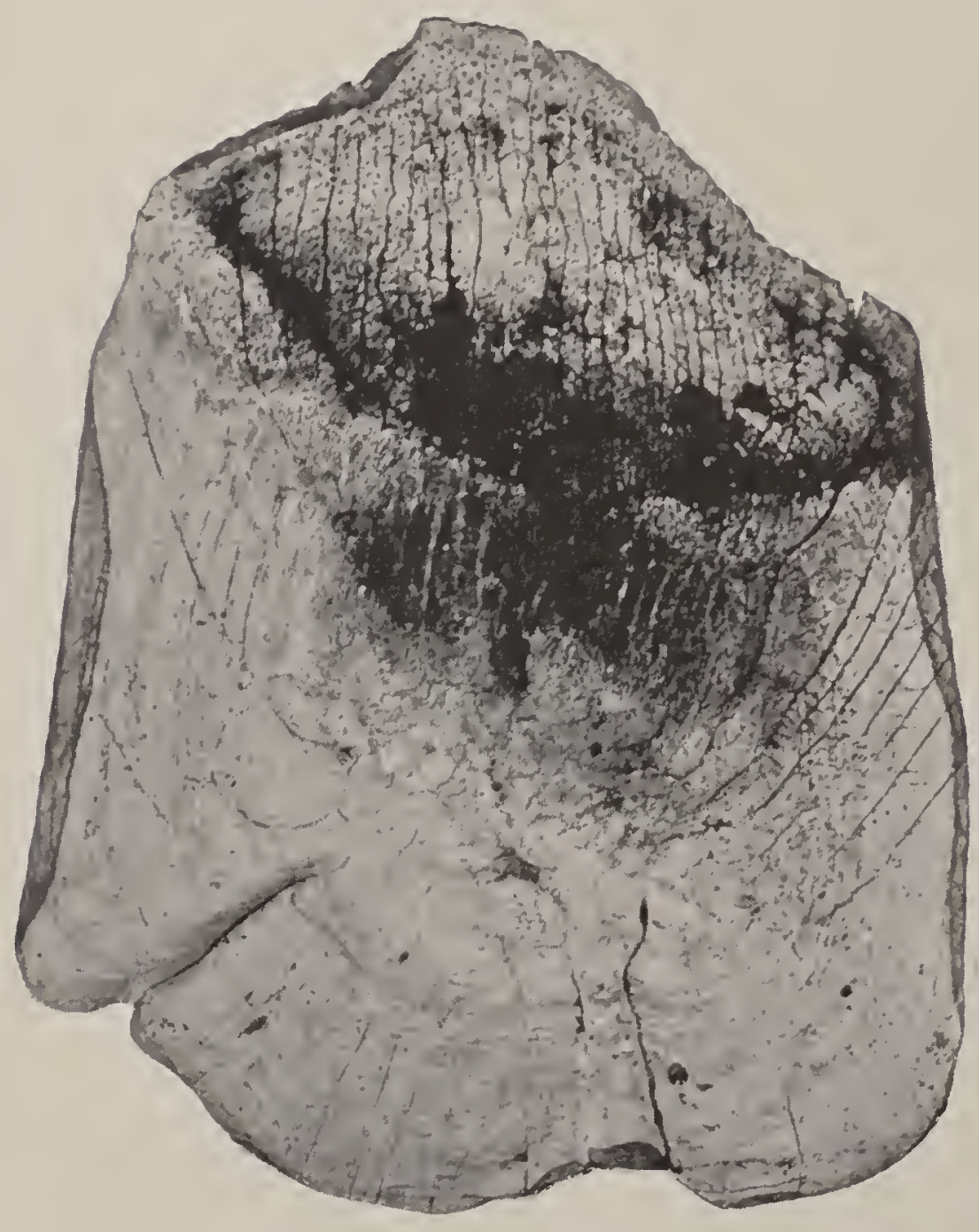

I5
PLATE XXXIV.

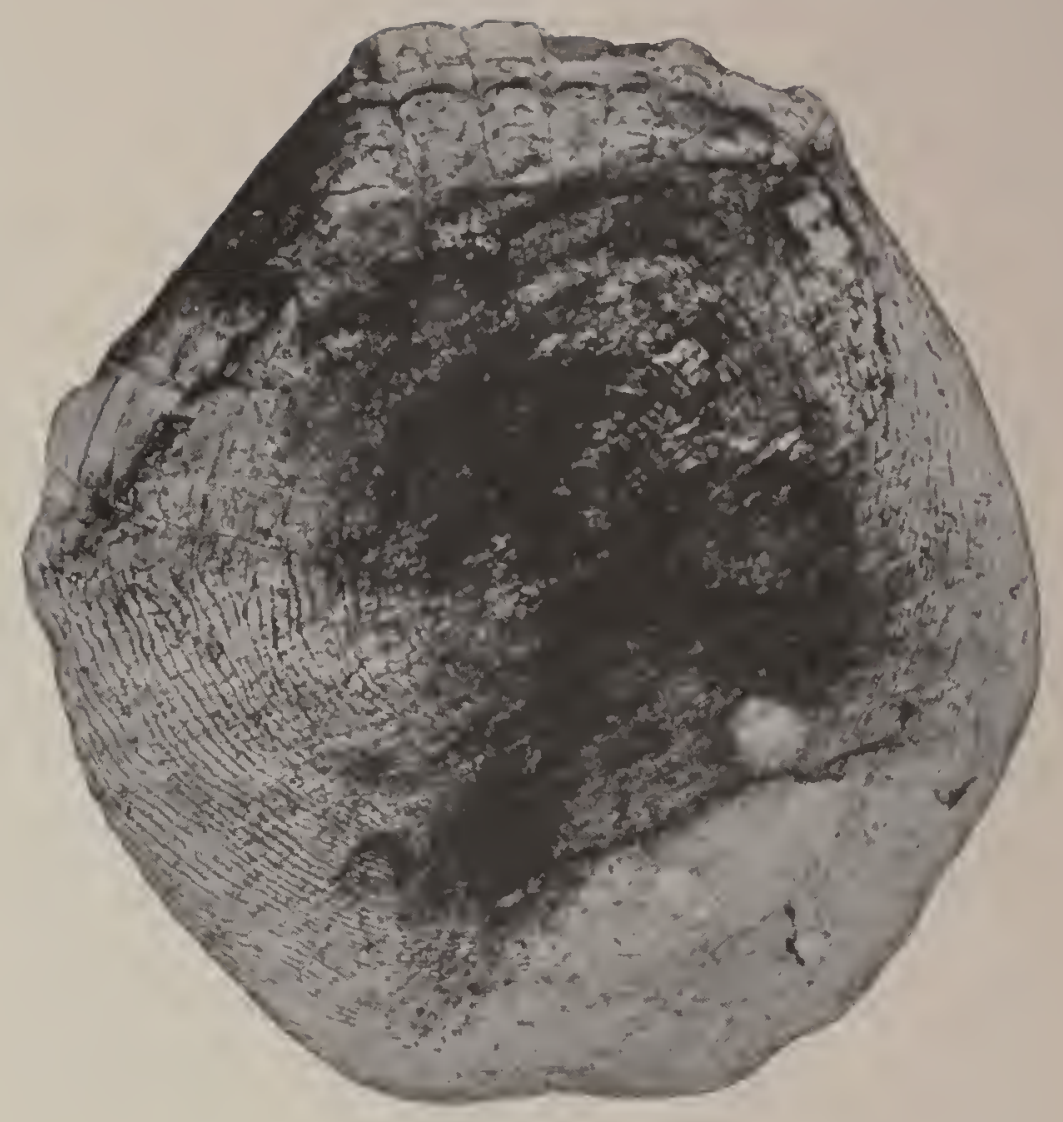

I4
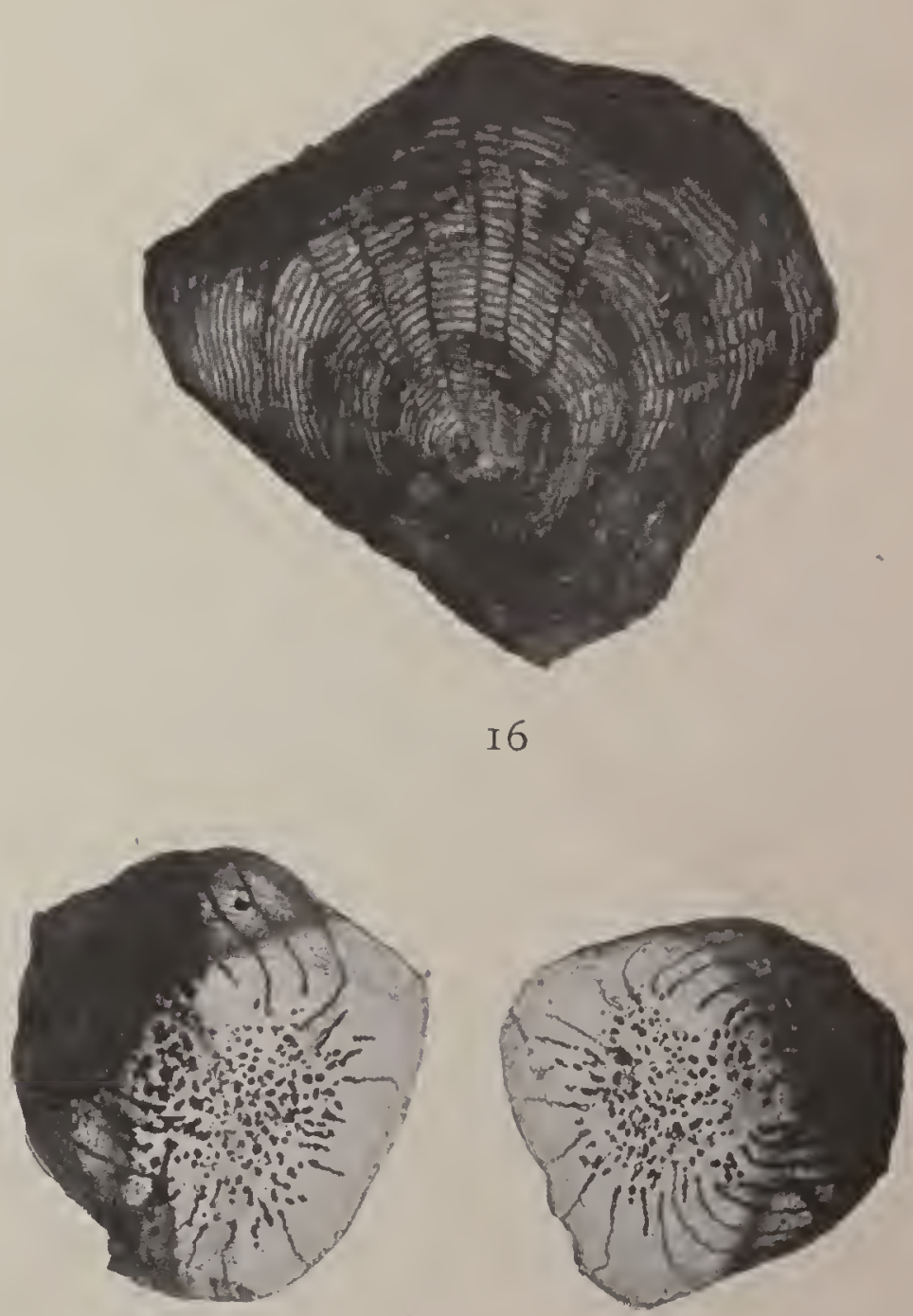

I 7

FIG. 13.-Capoeta fratercula. Persia. British Museum.

FIG. I4.-Culter erythropterus. R. Keroulen, Mongolia (Chaffanjon). British Museum.

FIG. 35-L eptobarbus hoevenii. Tinjar River (C. Hose). British Museum.

FIG. I6. -Oreinus grahan1i. British Museum1.

FIG. I7.-Honnaloptera maculata. Khassya (Dr. Jerdon). British Museum. 


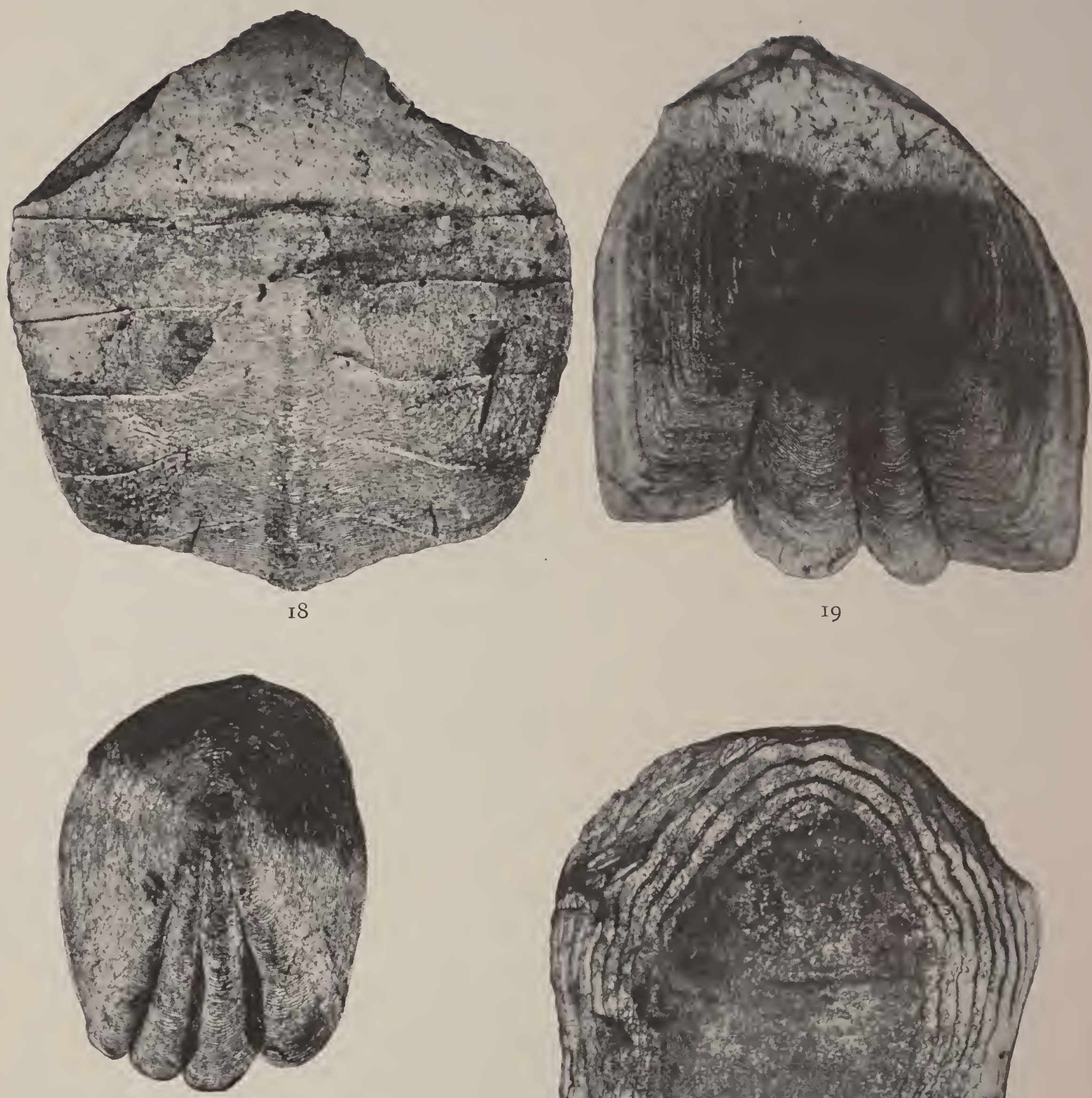

20
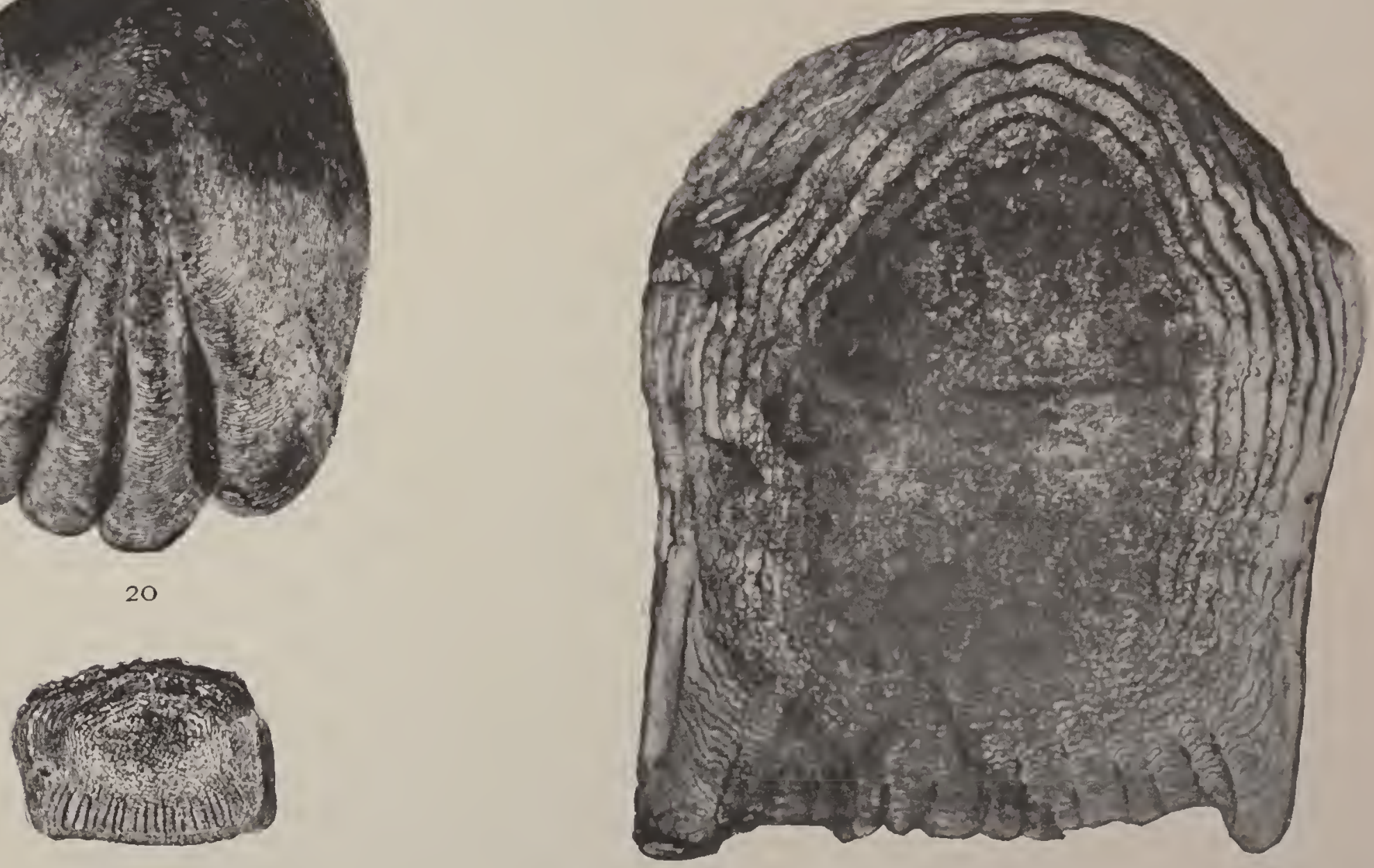

22

$2 \mathrm{I}$

FIG. 18.-Clupanodon psendohispanicus. Woods Hole, Mass.

FIr. 19.-Synodus foetens. Galveston, Texas (Evermann).

FIG. 20.-l, hicitus hucius. Toledo, Ohio (Rntter)

FIG. 22.-Fundulus heteroclitus. Woods Hole, irass. 



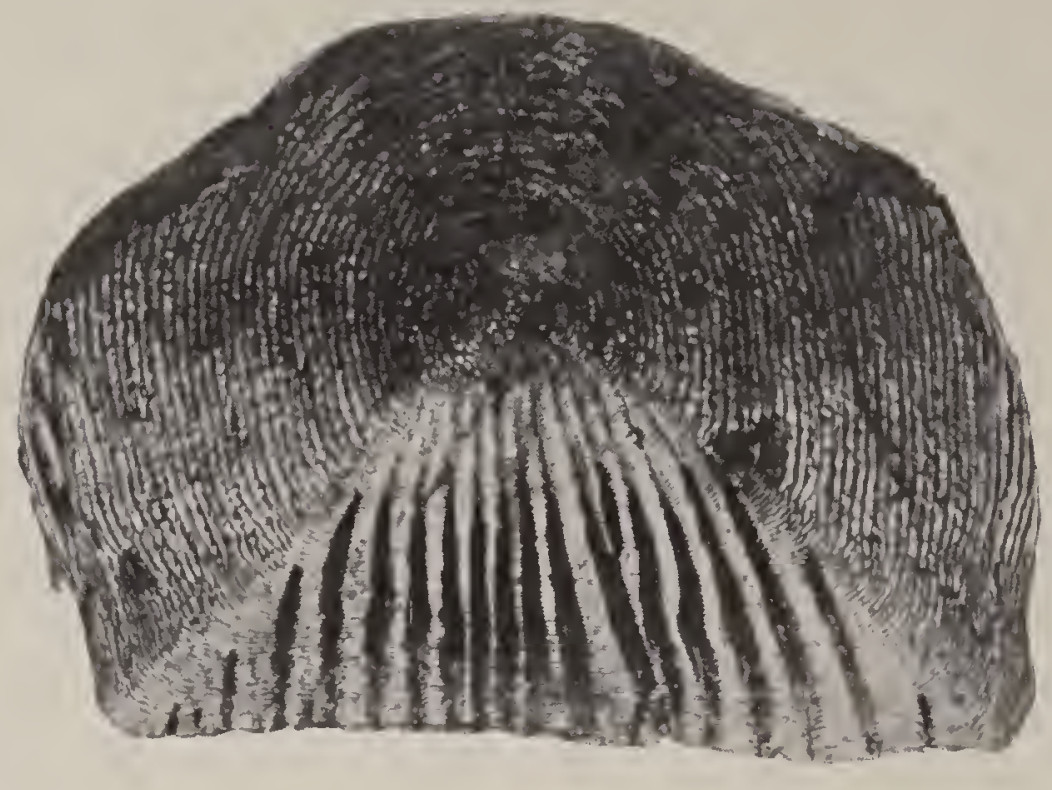

23

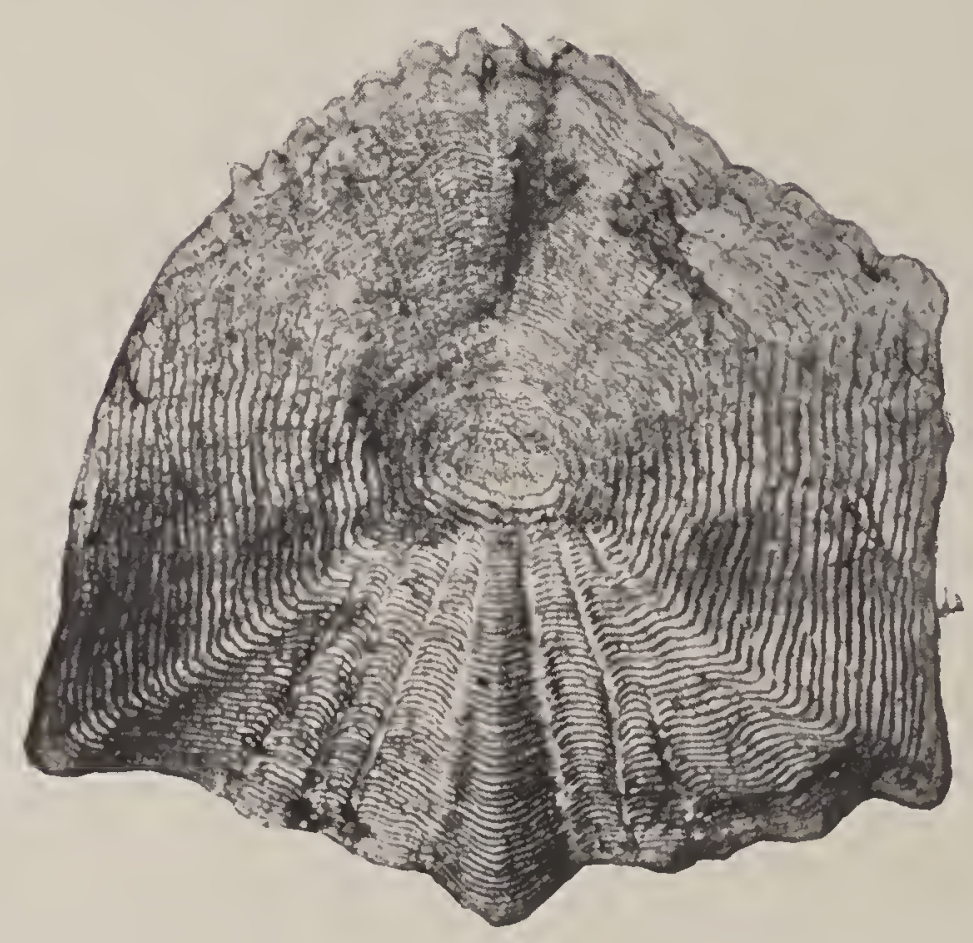

25

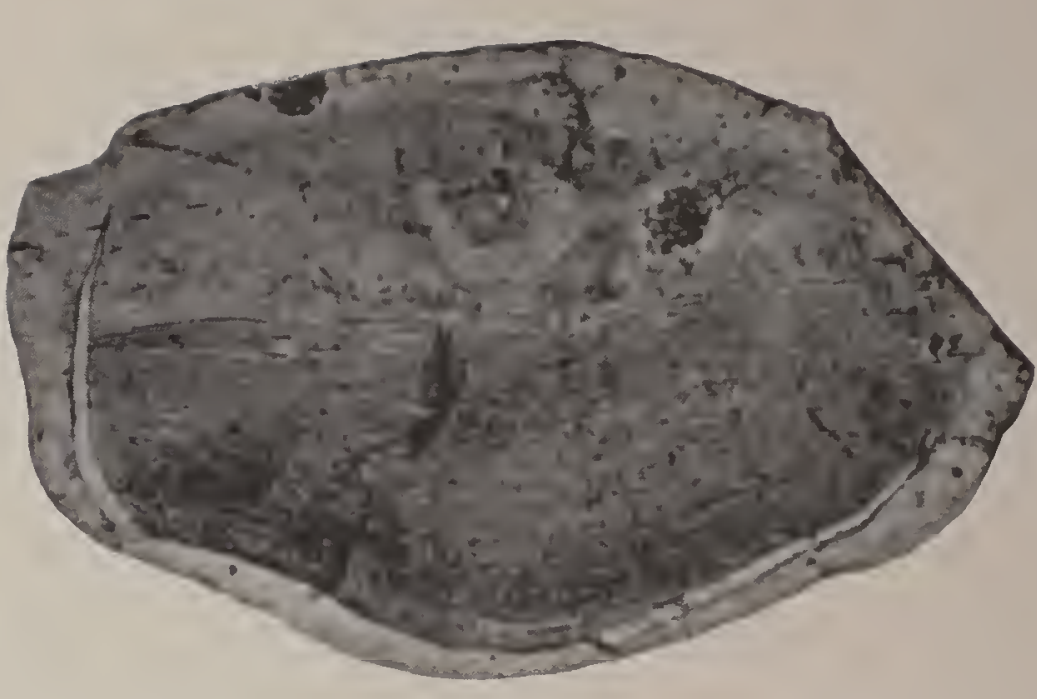

24

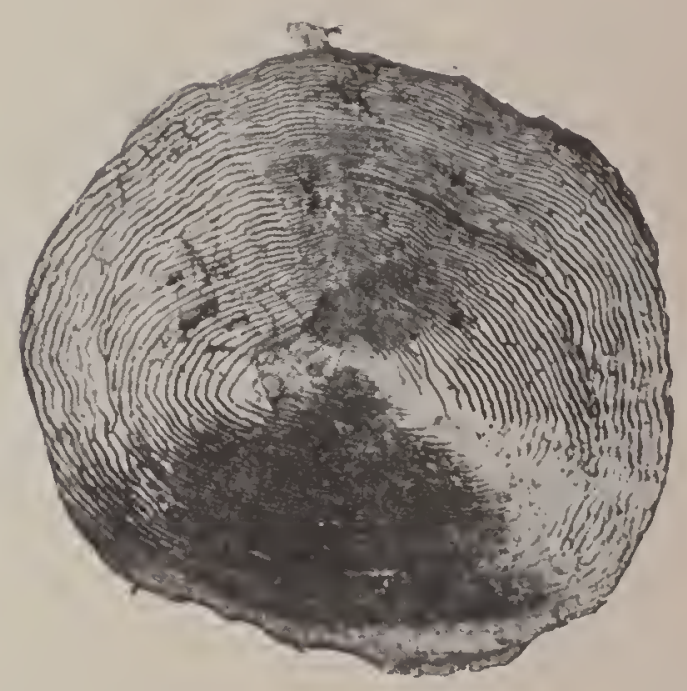

27

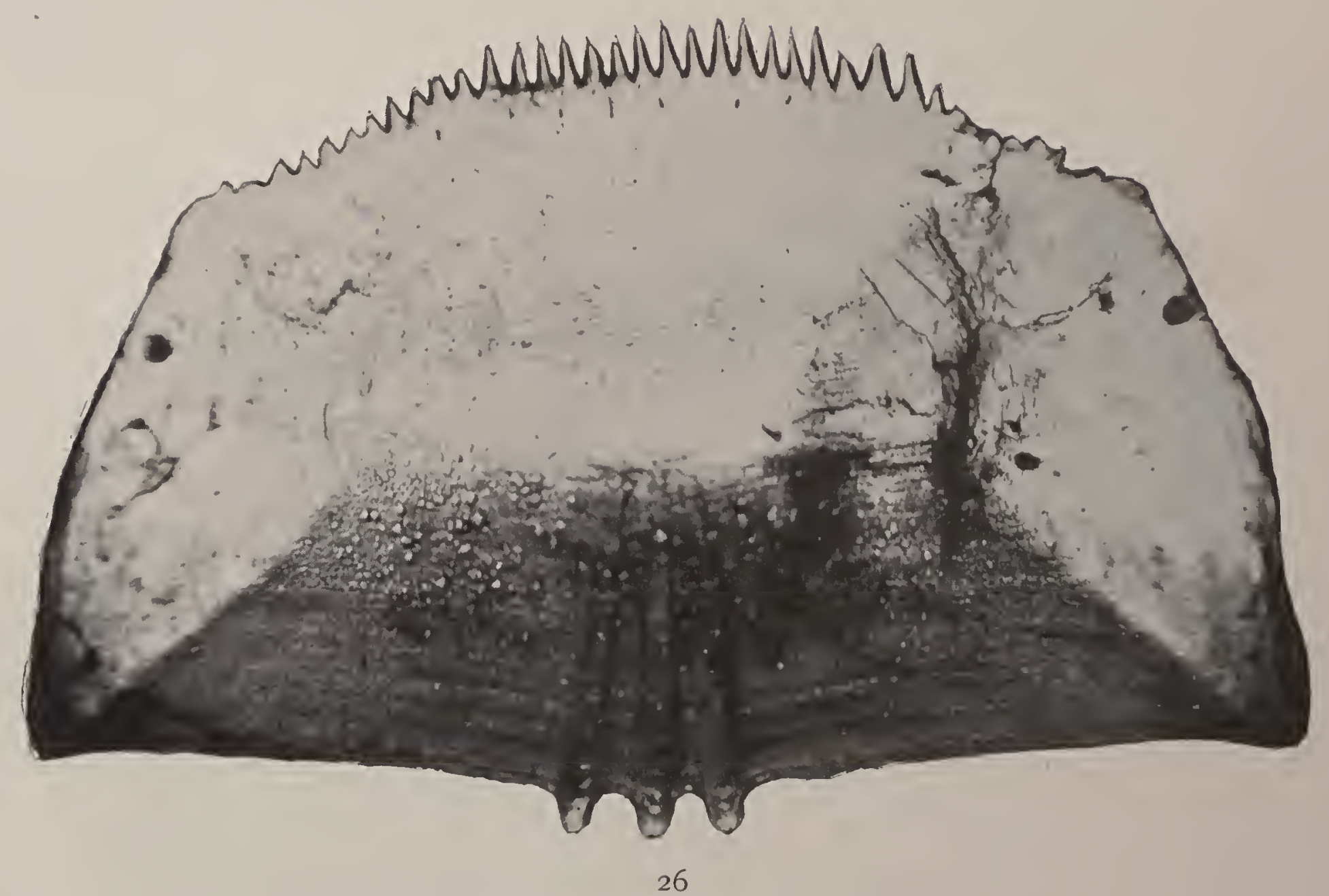

FIG. 23.-Mollienisia latipinna. Gordons Pass, Florida (Henslall1).

FIG. 24.-Scombresox saurus. Woods Holc Collectiour.

FIs, 25-Chirostoma crystallinum, Iake Cliapala, Irexico (J N Rose).

Fis. 26.-Holocentrun laticeps. Kani, II. I. Nusenm of Conparative Zoology.

Fig. 27.-Caranx lippos. Woods Holc Collcction. 



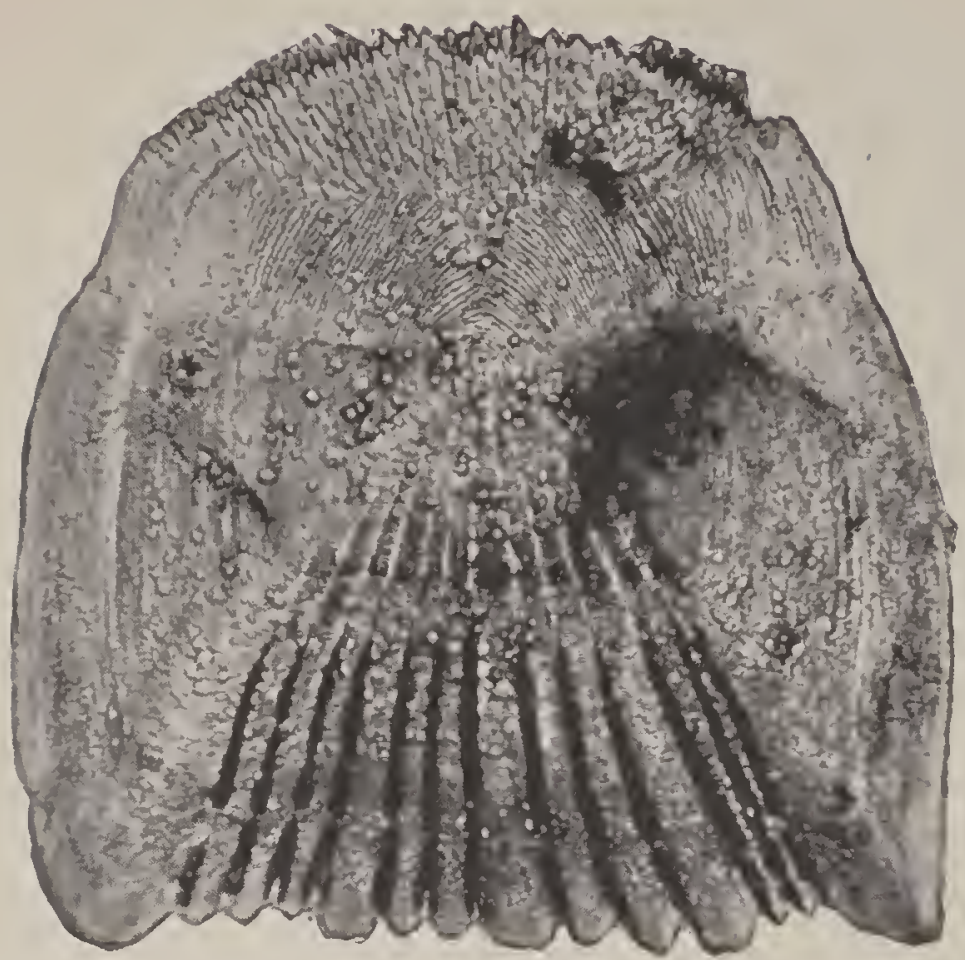

$2 S$
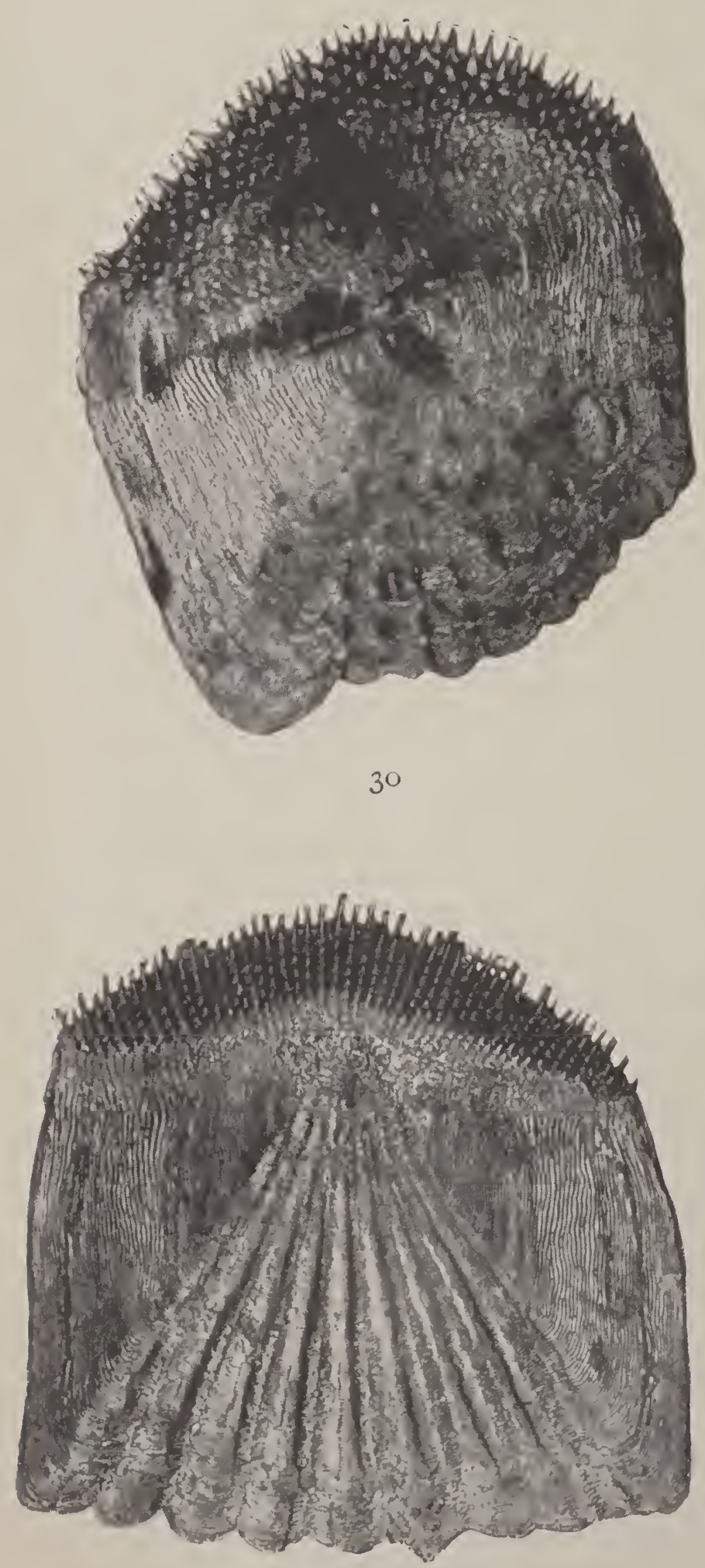

33

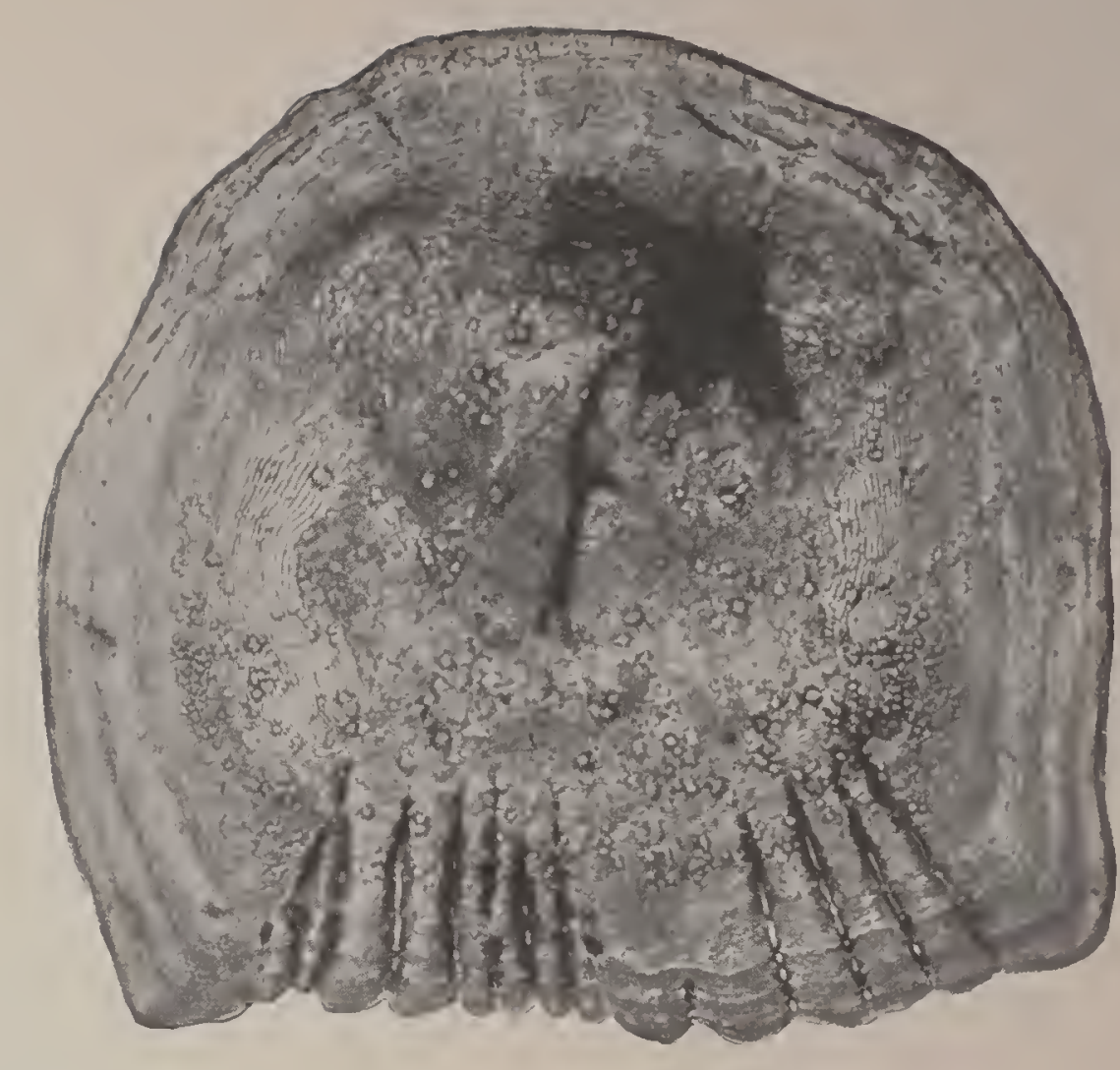

29

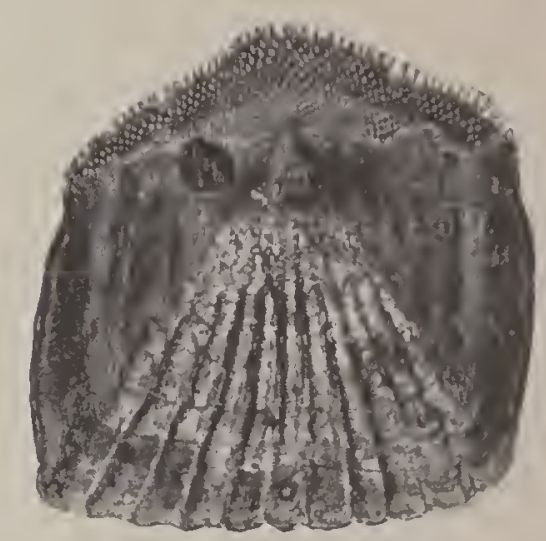

3 I

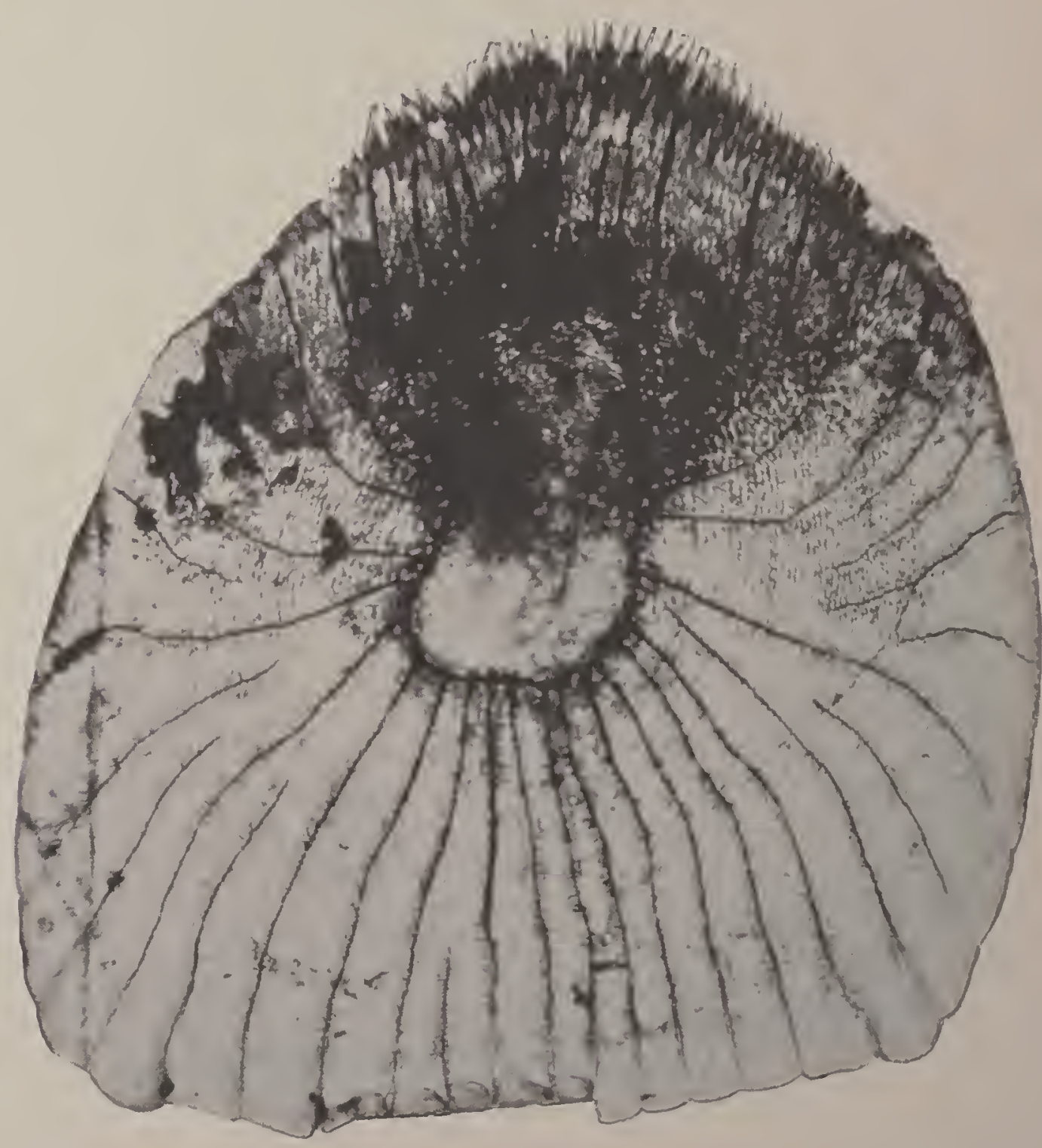

32

Firr. 28.-Mesogonistius chactodon. Trenton, N. J.

linc. 29.-Aunbloplites rupestris. Huntington, 'Ten11.

firc. 30.-A rchoplites interruptus. Sanl l rancisco, Cal.

IiIs. 31.-Centropristes striatus. Woods Hole, IIass.

Iir (̇. 32.-. Plesiops corallicola. Ebon Islands. Mrusenum of Comparative Zoology.

Fig. 33.-Ortlopristis clialceus. Guaymas or Clarion Island. (Albatross). 


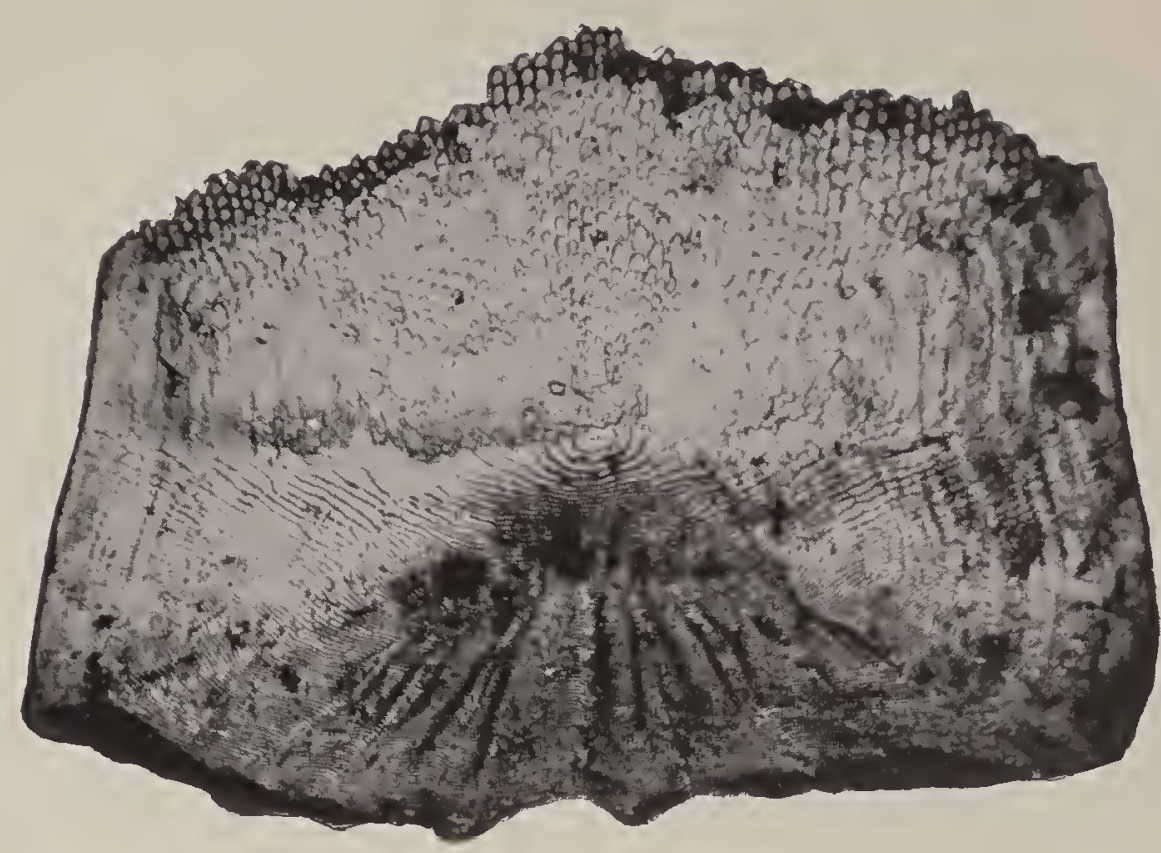

34

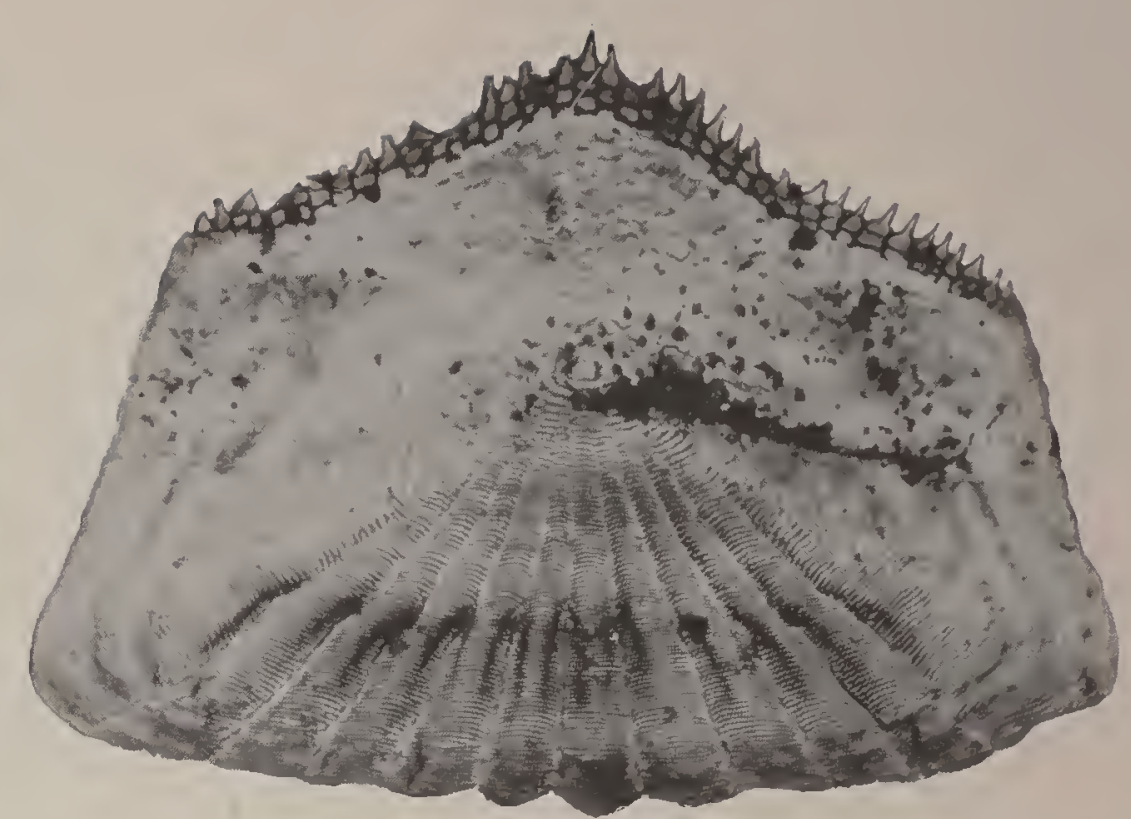

35

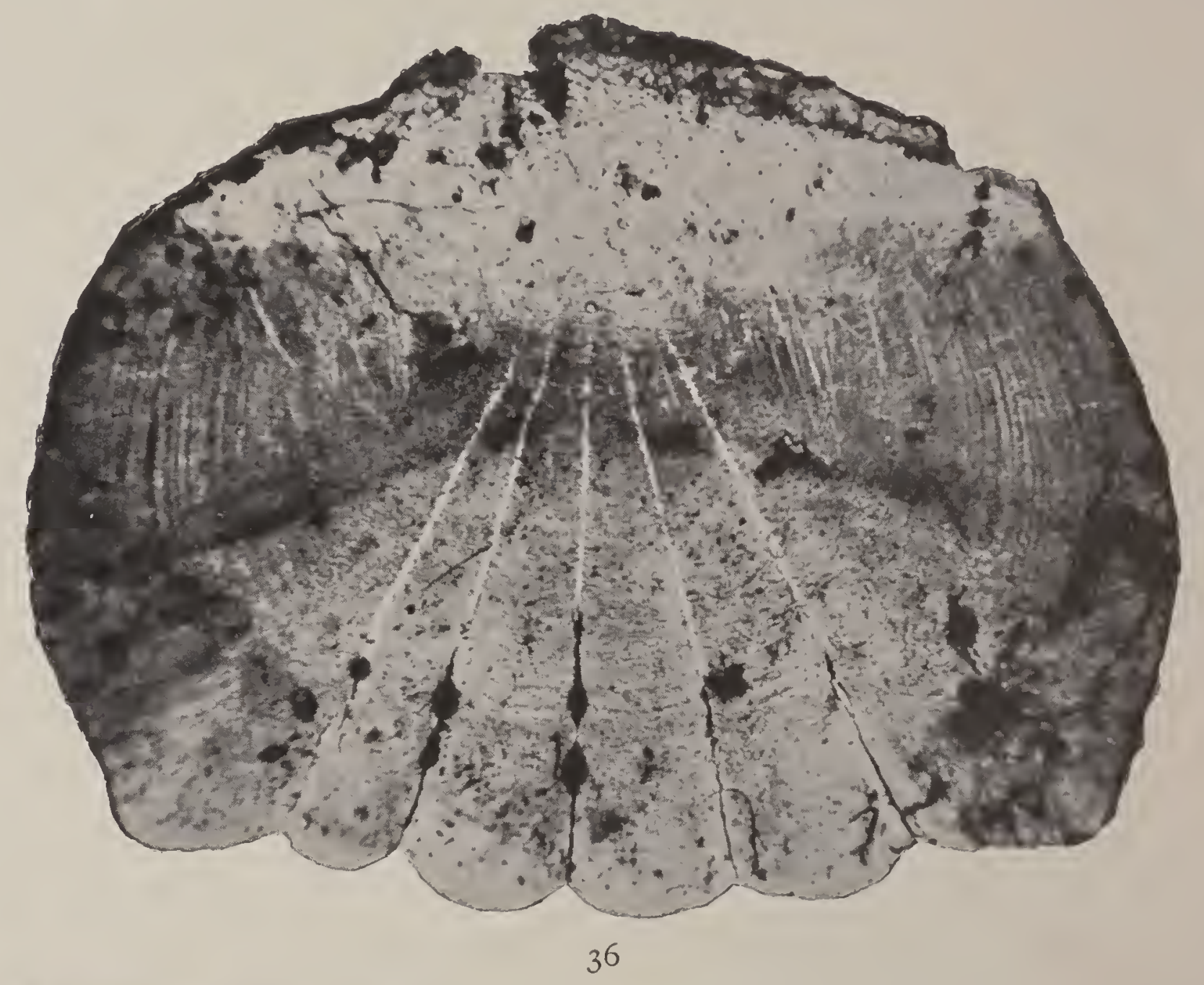

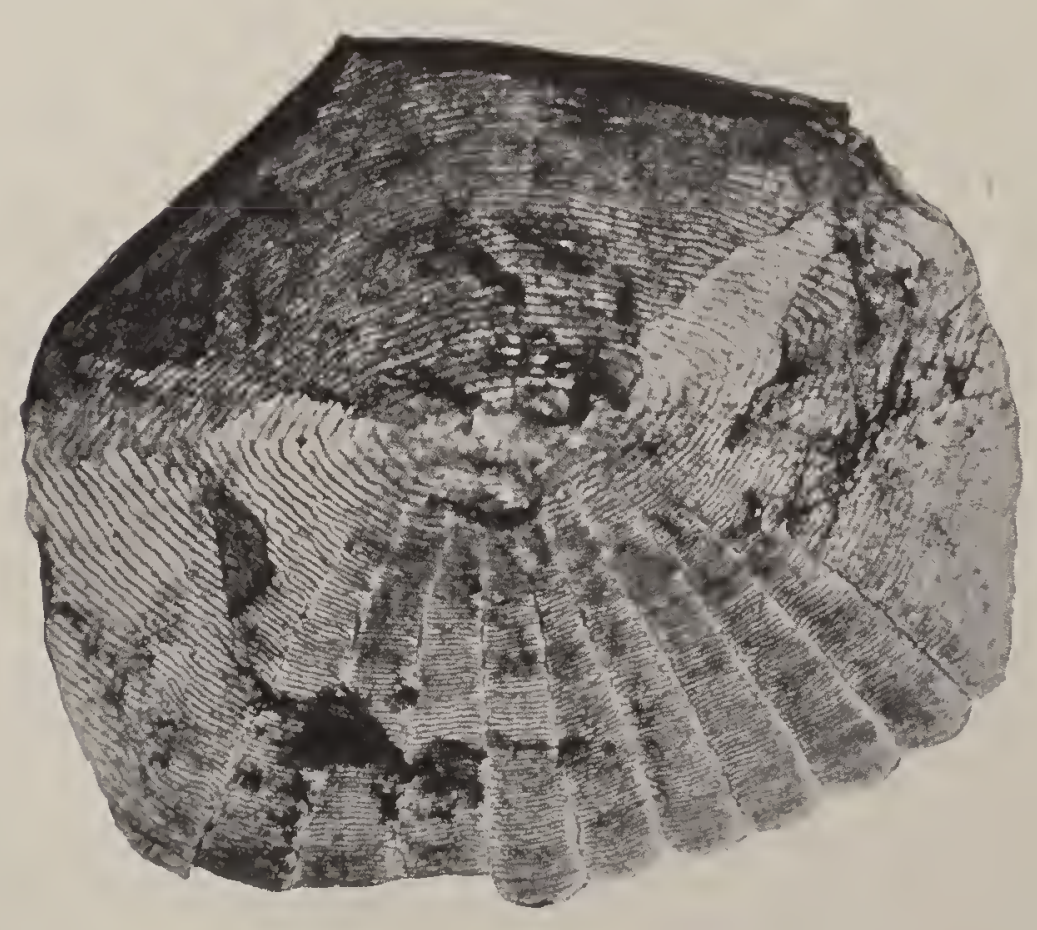

37

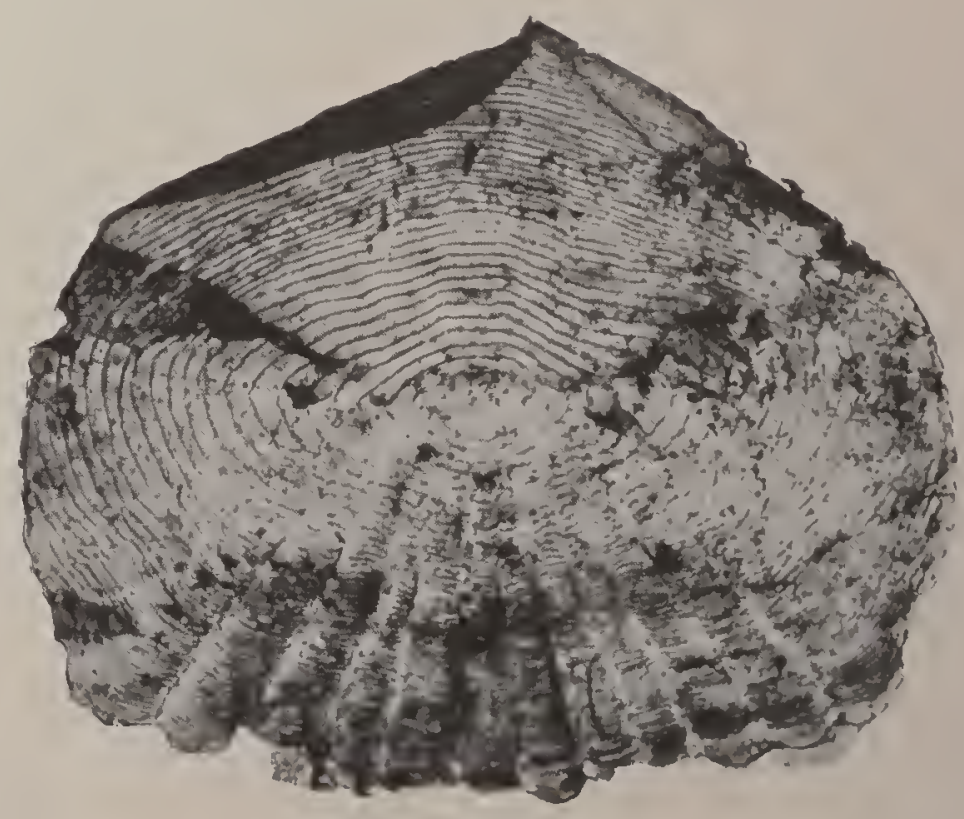

$3 \mathrm{~S}$

Fig. 34.-Box vulgaris. Vienua Museum.

FIG. 35. - Smaris sp. 'Trieste.

Fig. 36.-Gerres grula. Mrazil. Musenum of Comparative Zoology.

FIG. 37.-Anuplistiens argentens. St. Nielolas Island. (Albatross.)

FIG. 38. - Zalembius rosaceus. Above Santa Barbara Cliannel, (Albatross.) 



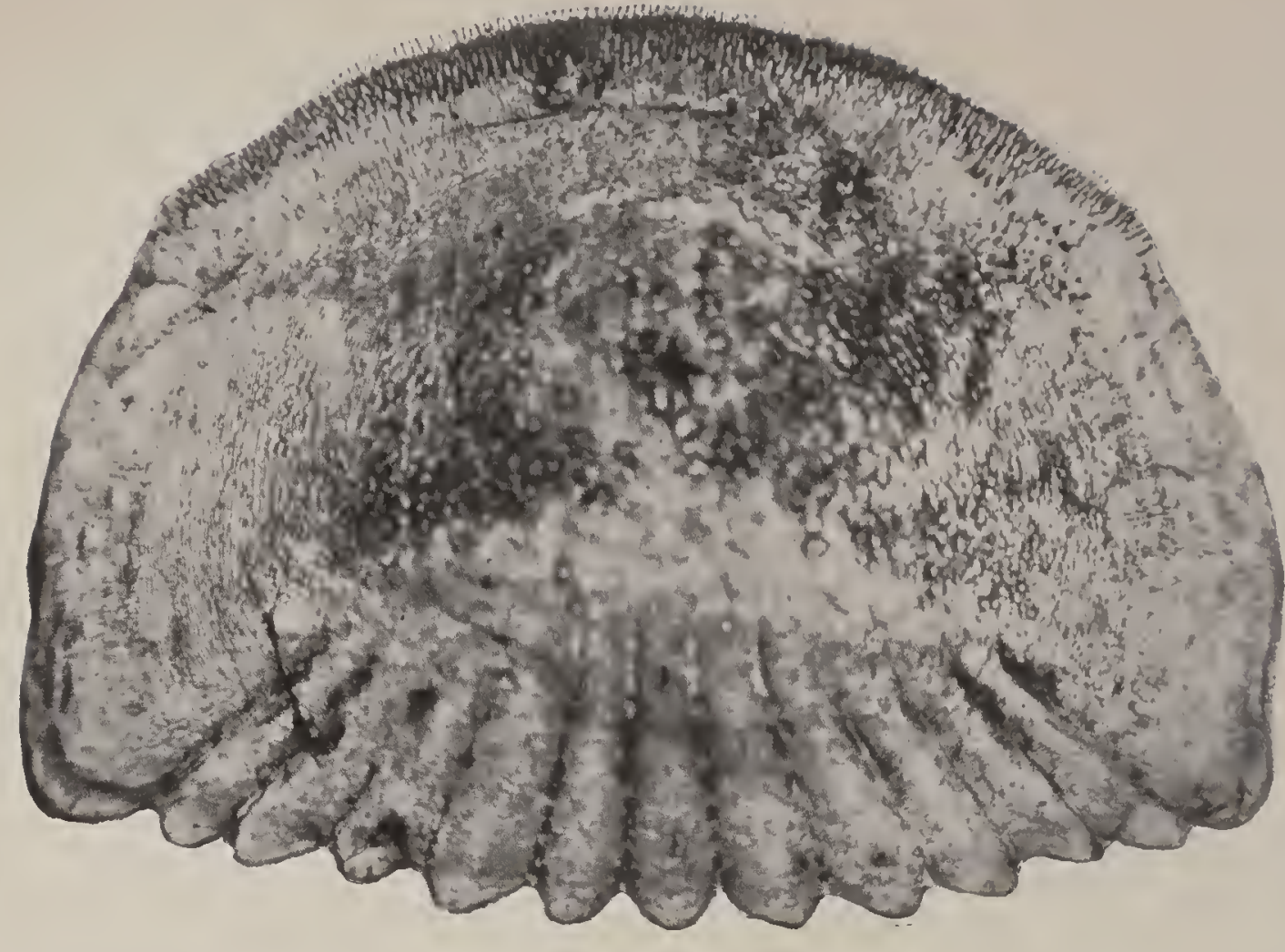

39

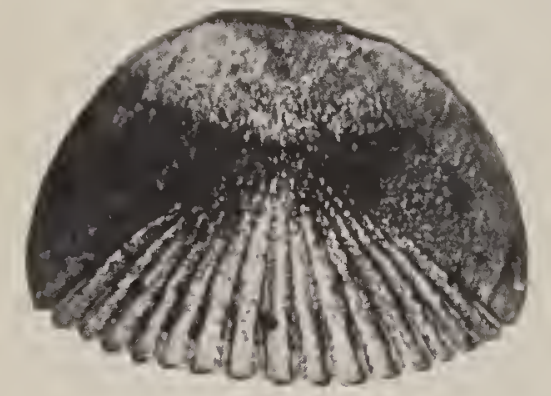

$4 \mathrm{I}$

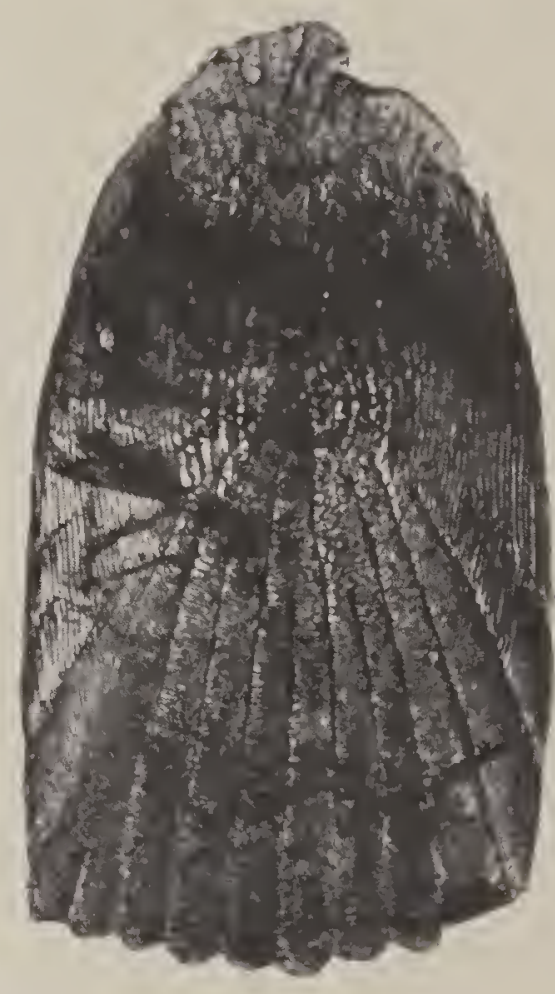

42

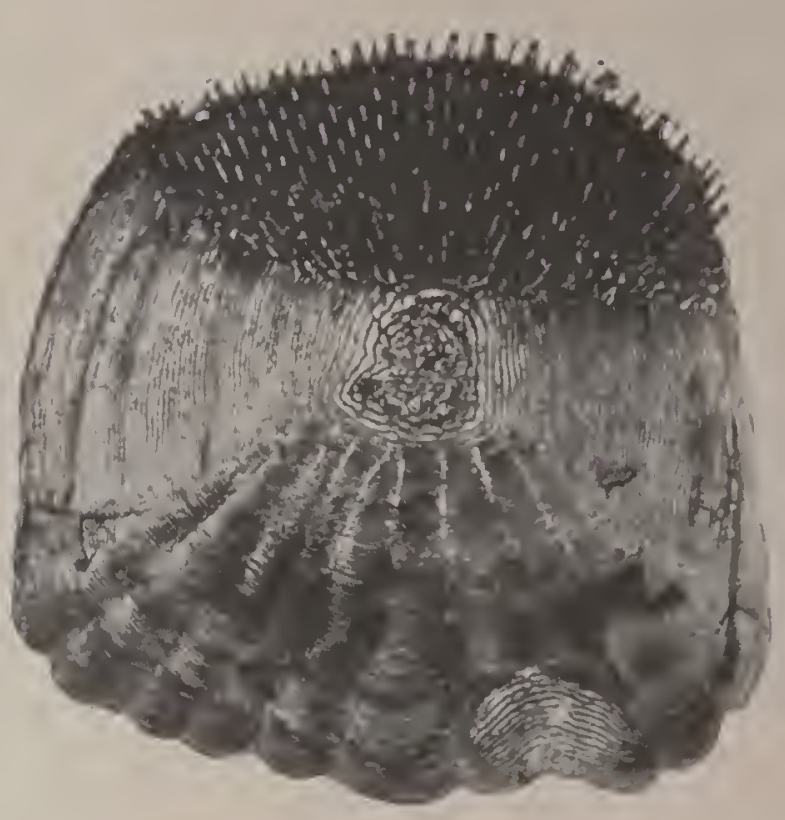

40

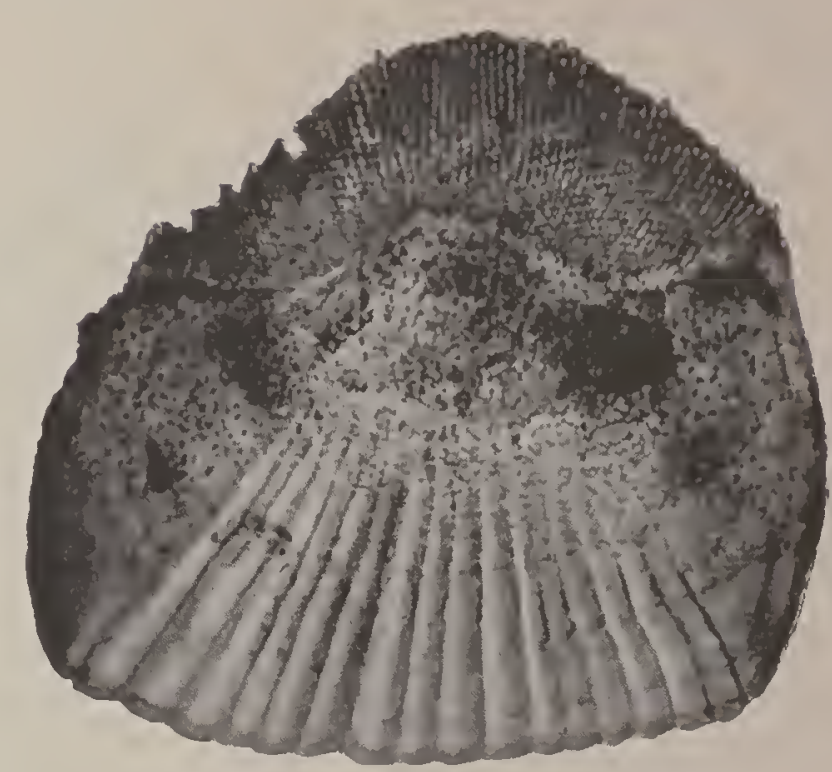

45

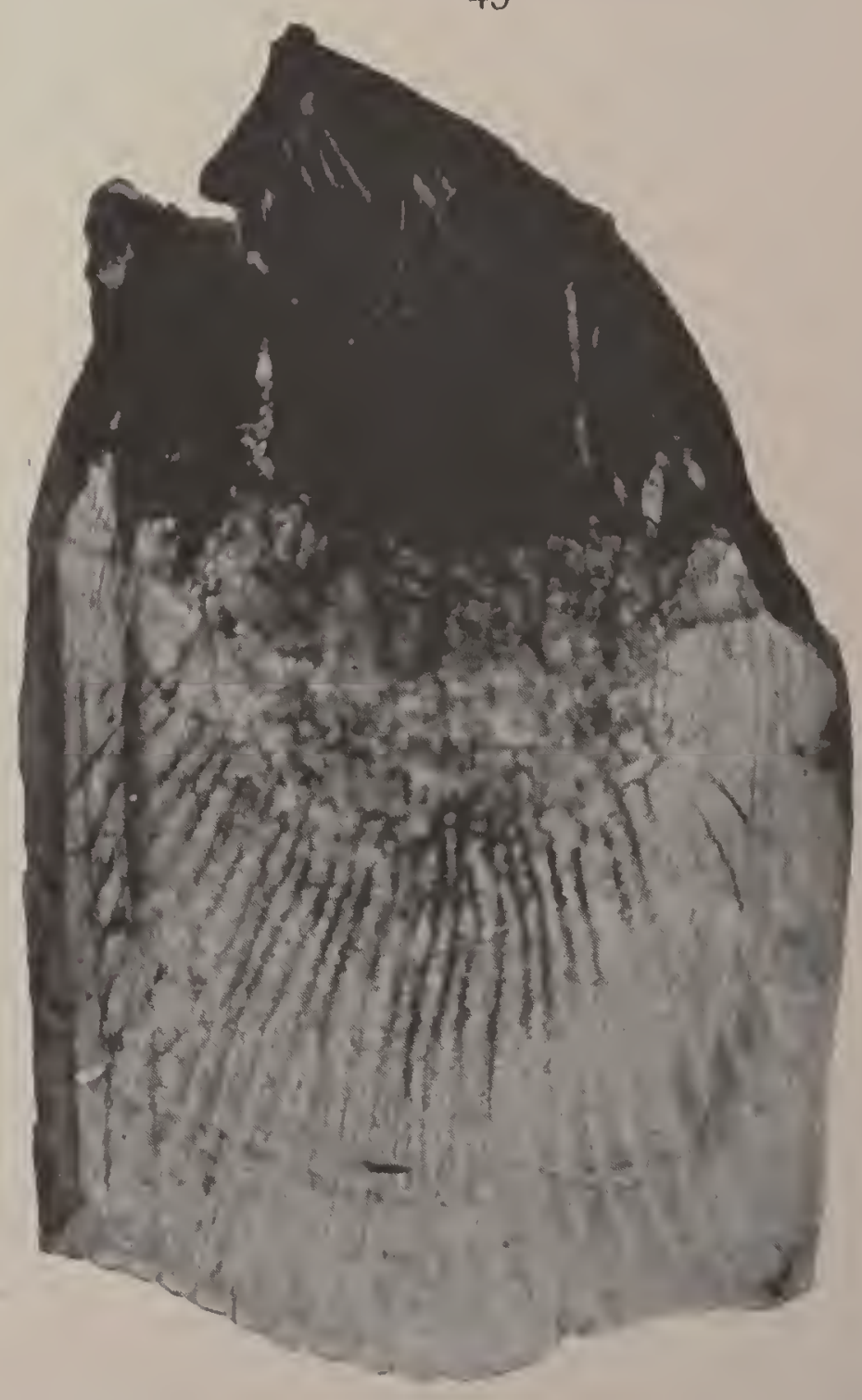

43

FIG. 39.-Geopluagus brasiliensis. Rio Novo, Brazil.

Fig. 40.-Cichla monoculis. I,ake Hyannary, Brazil. Muscum of Conparative \%oology.

FIG. 41.-Chxtobranchns navescens. I, ake IIyannary, Brazi

litg. 42.-Pinclonctopon pinclier. Santa Barbara Islands. (Allatruss.)

Fig. 43.--Fintilekia ventista. (Jilf of California. (Albatross.)

I'IG. 45.-Chaetodon nlietensis. Apia, Samoa. (Jordin1.) 



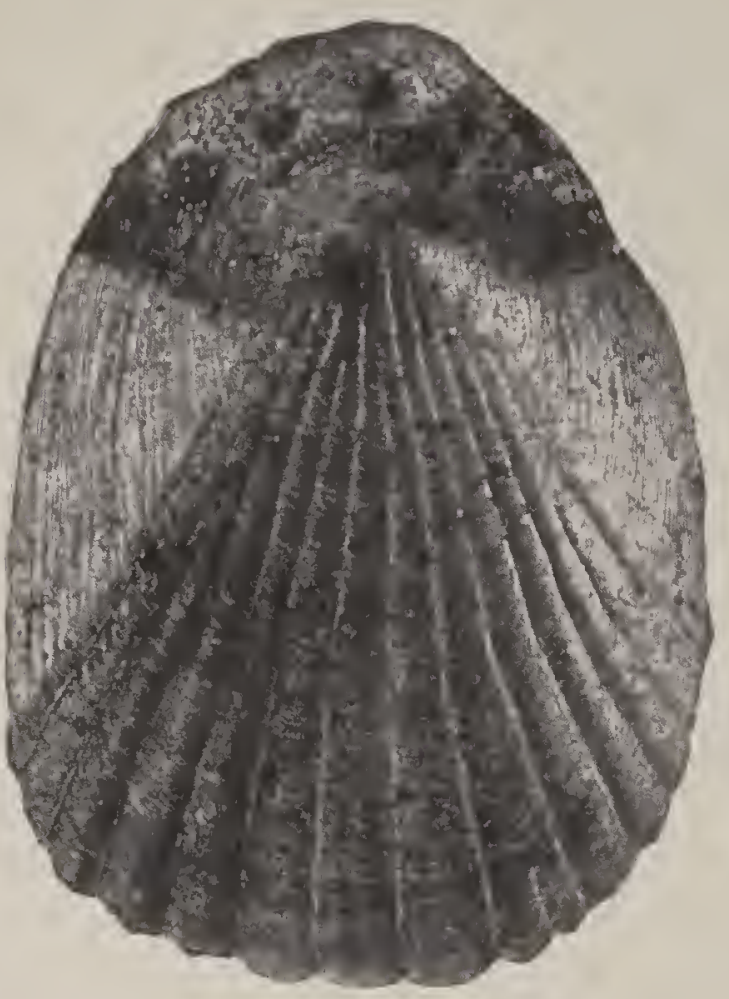

46

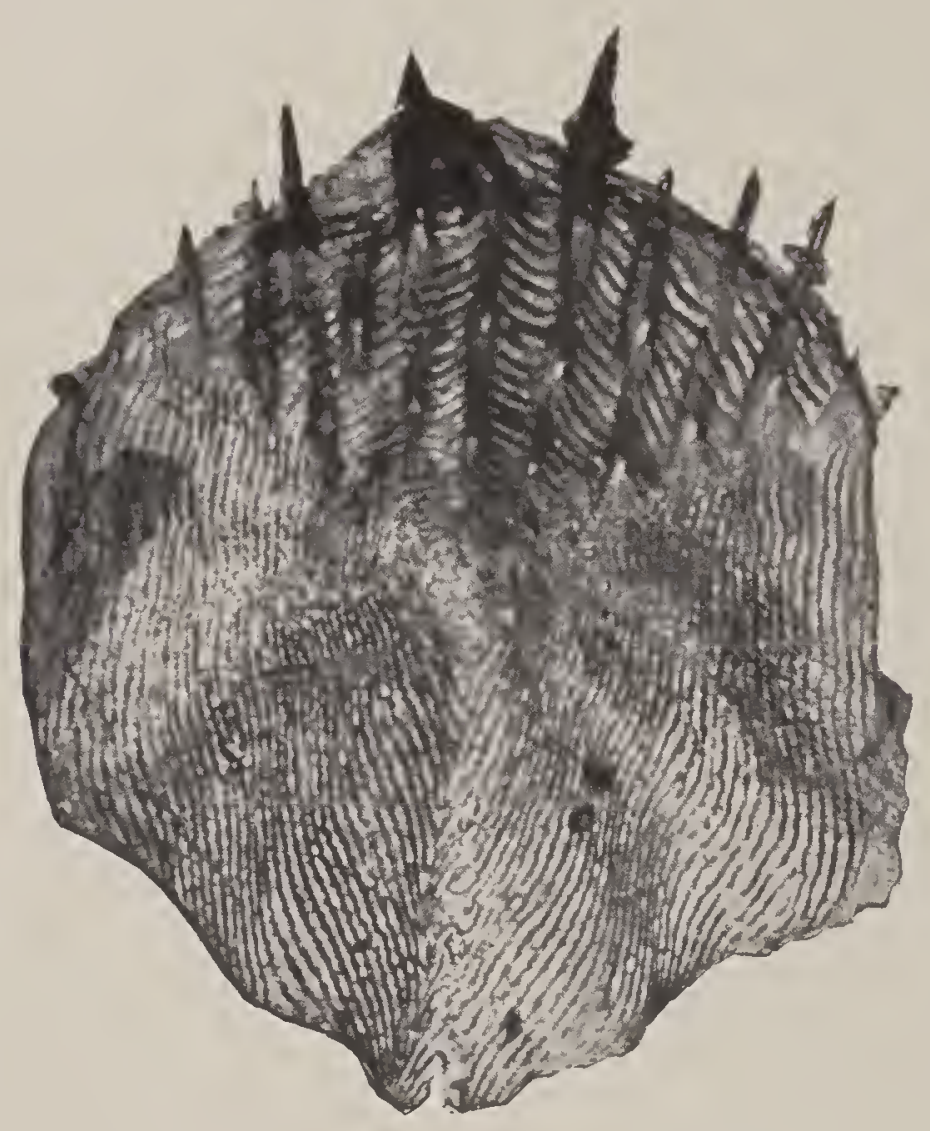

48

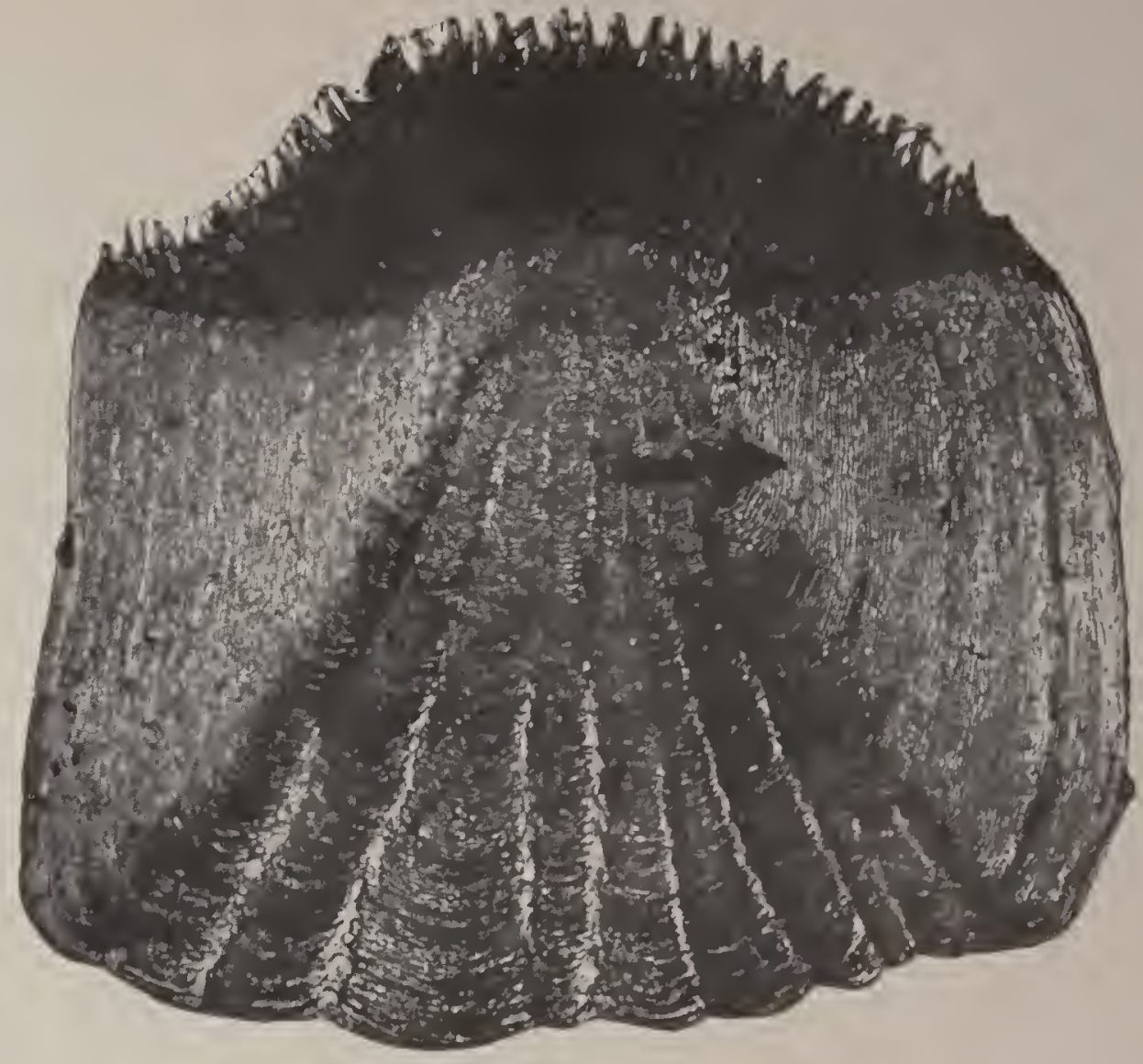

47

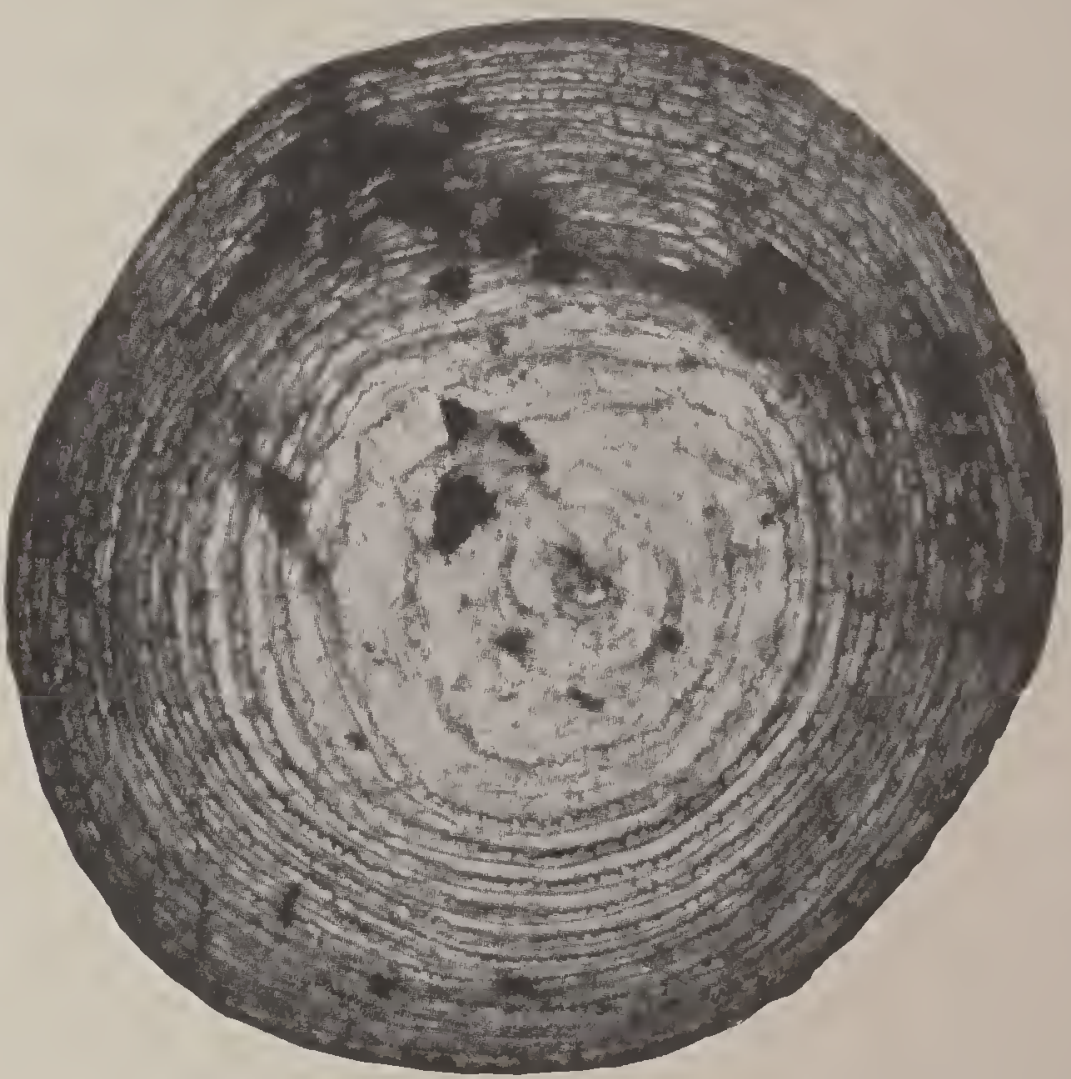

49

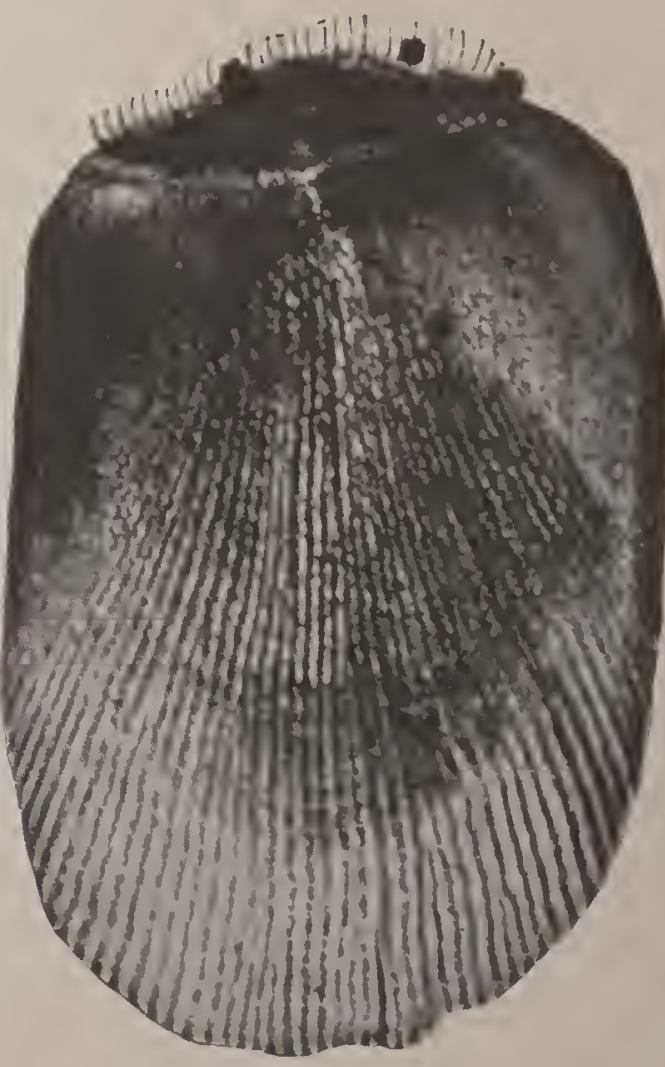

52

FIG. 46.- Helicolenus dactylopterus. Off Woods Hole.

FIG. 47.-Prionotus strigatus. Woods Hole, Mass.

FIG. 48. - Macrurus sp. Albatross station 2426.

Fig. 49. - Lota vulgaris. Danube. Musen111 of Comparative 'Zoology.

FIC. 50.-Gadus callarias. Woods Hole Collection.

Fig. 52.-Cynoglossus sp., upper side. Hongkong. Musem of Comparative \%oology. 







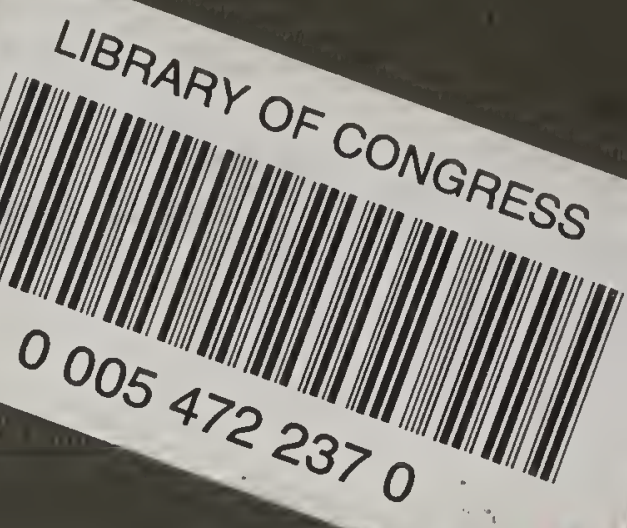

